
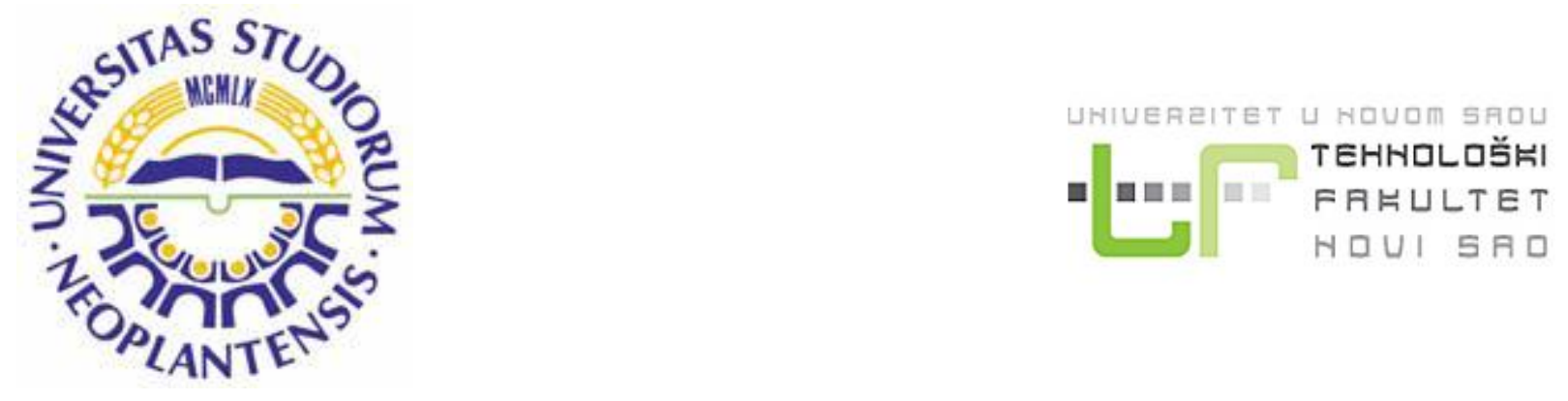

UNIVERZITET U NOVOM SADU

TEHNOLOŠKI FAKULTET

mr Snežana Filip

Ekstrakcija bosiljka (Ocimum basilicum, Lamiaceae) ugljendioksidom u superkritičnom stanju i modelovanje ekstrakcionog sistema

DOKTORSKA DISERTACIJA

Mentor: Prof. dr Zoran Zeković

Novi Sad, 2014 


\section{UNIVERZITET U NOVOM SADU}

\section{TEHNOLOŠKI FAKULTET}

\section{KLJUČNA DOKUMENTACIJSKA INFORMACIJA}

\section{Redni broj: \\ RBR \\ Identifikacioni broj: \\ IBR}

Tip dokumentacije:

TD

Tip zapisa:

TZ

Vrsta rada (dipl., mag., dokt.):

VR

Ime i prezime autora:

AU

Mentor (titula, ime, prezime, zvanje):

MN

Naslov rada:

NR

Jezik publikacije:

JP

Jezik izvoda:

JI

Zemlja publikovanja:

$\mathbf{Z P}$

Uže geografsko područje:

UGP

Godina:

GO

Izdavač:

IZ

Mesto i adresa:

MA
Monografska dokumentacija

Tekstualni štampani materijal

Doktorska disertacija

Snežana Filip

Prof. dr Zoran Zeković, redovni profesor

Ekstrakcija bosiljka (Ocimum basilicum, Lamiaceae) ugljendioksidom u superkritičnom stanju i modelovanje ekstrakcionog sistema

Srpski, latinica

srp. / eng.

Republika Srbija

AP Vojvodina

2014

autorski reprint

21000 Novi Sad, Bulevar cara Lazara 1 
Fizički opis rada:

FO

Naučna oblast:

NO

Naučna disciplina:

ND

Predmetna odrednica, ključne reči:

PO

\section{UDK}

Čuva se:

ČU

Važna napomena:

VN

Izvod:

IZ
7 poglavlja, 123 stranice, 35 slika, 30 tabela, 136 referenci, 26 priloga

Tehnološko inženjerstvo

Farmaceutsko inženjerstvo

Bosiljak (Ocimum basilicum L.), superkritična ekstrakcija, ekstrakti, etarsko ulje, modelovanje ekstrakcionog sistema, antioksidativno delovanje

Biblioteka Tehnološkog fakulteta u Novom Sadu, Bulevar cara Lazara 1, 21000 Novi Sad Nema

U okviru ove doktorske disertacije, proučavana je ekstrakcija bosiljka (Ocimum basilicum L.) primenom postupka hidrodestilacije, Soxhlet ekstrakcije i ugljendioksidom u superkritičnom stanju. Određen je sadržaj etarskog ulja u drogi $(0,565 \%)$, a primenom GC/MS(FID) metoda određen kvalitativni i kvantitativni sastav detektovanih komponenata. Identifikovane komponente svrstane su $\mathrm{u}$ nekoliko grupa (monoterpeni, seskviterpeni i njihovi oksidovani derivati). Rezultati ispitivanja pokazuju da je dominantno jedinjenje etarskog ulja bosiljka linalool (50,09\%), i da ono pripada linaloolskom hemotipu (hemotip A).

Ispitan je uticaj temperature $\left(40-60^{\circ} \mathrm{C}\right)$ i pritiska (100-300 bar) superkritičnog ugljendioksida na promenu prinosa ekstrakta. Utvrđeno je da se kumulativni prinos ekstrakta povećava sa porastom pritiska ekstrakcije, dok u zavisnosti od temperature, prinos ekstrakcije zavisi od gustine rastvarača i napona pare komponenata $u$ ekstraktu.

Primenom sukcesivne (frakcione) superkritične ekstrakcije izvršeno je frakcionisanje, a dobijeni ekstrakti upoređivani u pogledu prinosa, kvalitativnog i kvantitativnog sastava.

Ispitivanja hemijskog sastava $\mathrm{CO}_{2}$ ekstrakta (GC/MS i GC/FID) pokazala su da ekstrakti pored komponenata etarskog ulja sadrže i druga lipofilna jedinjenja (voskove, masna ulja, masne kiseline, fitosterole i sl.). Dominantne komponente u svim ispitivanim ekstraktima su 
Datum prihvatanja teme od strane NN veća:

DP

Datum odbrane:

DO

Članovi komisije:

KO

predsednik:

član:

član: linalool, eugenol i $\delta$-kadinen, dok su $\alpha$ bergamoten, germakren $\mathrm{D}, \gamma$-kadinen, $\beta$-selinen i spatulenol komponente sa manjim saržajem.

$\mathrm{Na}$ osnovu eksperimentalnih rezultata kinetike superkritične ekstrakcije izvršeno je modelovanje ekstrakcionog sistema bosiljak superkritični $\mathrm{CO}_{2}$, primenom tri modela (Kandiah i Spiro, Brunner i Esquivel i sar.). $\mathrm{Na}$ osnovu srednjih vrednosti relativnog odstupanja modelovanih i eksperimentalnih vrednosti prinosa ekstrakcije, utvrđeno je da model Kandiah i Spiro pokazuje prihvatljivo slaganje, dok ostali modeli pokazuju lošije slaganje eksperimentalno određenih i modelom izračunatih prinosa ekstrakta.

U završnoj fazi rada ispitan je antioksidativni potencijal etarskog ulja i $\mathrm{CO}_{2}$ ekstrakata, primenom DPPH metode. Najveću antioksidativnu aktivnost pokazao je ekstrakt dobijen na $100 \mathrm{bar}, 60^{\circ} \mathrm{C}\left(\mathrm{IC}_{50}=18,93 \mu \mathrm{g} / \mathrm{ml}\right)$, koja je 5 puta veća od antioksidativne aktivnosti etarskog ulja bosiljka.

05.03 .2013 


\title{
University of Novi Sad
}

\author{
Faculty of Technology
}

\section{KEY WORD DOCUMENTATION}

Accession number:

ANO

Identification number:

INO

Document type:

Monograph documentation

DT

Type of record:

TR

Contents code:

Textual printed material

CC

PhD Thesis

Author:

Snežana Filip

AU

Mentor:

$\mathrm{PhD}$ Zoran Zeković, professor

MN

Title:

TI

Extraction of basil by supercritical carbon dioxide (Ocimum basilicum L.) and modeling of the extraction system

Language of text:

Serbian

LT

Language of abstract:

LA

Serbian/English

Country of publication:

CP

Republic of Serbia

Locality of publication:

LP

Vojvodina

Publication year:

2014

PY

Publisher:

Author's reprint

PU

Publication place:

PP

21000 Novi Sad, Bulevar cara Lazara 1 
Physical description:

PD

Scientific field

SF

Scientific discipline

SD

Subject, Key words

SKW

UC

Holding data:

HD

Note:

$\mathbf{N}$

Abstract:

AB
7 chapters, 123 pages, 35 figures, 30 tables, 136

references, 26 accessories

Technological engineering

Pharmaceutical engineering

Basil (Ocimum basilicum L.), supercritical fluid extraction, extracts, essential oil, modeling of extraction system, antioxidant activity

Library of Faculty of Technology, Novi Sad, 21000 Novi Sad, Serbia, Bulevar cara Lazara 1

None

In this study, the extraction of basil ( $O$. basilicum L.) ussing the hydrodistillation process, Soxhlet extraction and supercritical extraction with carbon dioxide were investigated. The content of essential oil was determined $(0,565 \%)$, and the qualitative and quantitative composition of detected coumpound was made by GC/MS(FID). The identified coumpounds were classified into five groups (monoterpenes, sesquiterpenes and their oxidative derivates). The results of investigation shows that the dominant compound of basil essential oil is linalool $(50,09 \%)$, and that it belongs to linalool chemotype (chemotype A).

The influence of temperature $\left(40-60^{\circ} \mathrm{C}\right)$ and pressure (100-300 bar) of supercritical carbon dioxide on extraction yields were studied. It was determined that the total yield of extract increases with the increaseing of extraction pressure, while the influence of temperature on the yield depends on the density of the solvent and vapor pressure of components in the extract. Fractional supercritical fluid extraction was performed, and obtained extracts were compared regarding of yield, and the qualitative and quantitative composition of the extract. Chemical analyses of $\mathrm{CO}_{2}$ extract by GC/MS and GC/FID showed that extract contains, besides essential oil componentes, other lipophilic compounds (waxes, fatty oils, fatty acids, phytosterols, etc.). The few compounds were dominant in all analyzed basil extracts: linalool, and to a lesser extent eugenol, $\delta$ cadinene, $\alpha$-bergamotene, germacrene $\mathrm{D}, \gamma$ cadinene, $\beta$-selinene and spathulenol. 
Based on the experimental results of the extraction kinetics, a modeling of basil supercritical $\mathrm{CO}_{2}$ extraction system was performed, using three models (Kandiah and Spiro, Brunner, and Esquivel et al.). Based on the average values of the relative deviations of modeled and experimental values of extraction yield, it was found that the model Kandiah and Spiro shows acceptable agreement, while other models show lower agreement of the experimentally determined and model calculated extraction yield.

In finale phase of work the antioxidant potential of essential oil and $\mathrm{CO}_{2}$ extracts were examined, using DPPH method. The highest antioxidant activity showed $\mathrm{CO}_{2}$ extract obtained at $100 \mathrm{bar}$, $60^{\circ} \mathrm{C}\left(\mathrm{IC}_{50}=18,93 \mu \mathrm{g} / \mathrm{ml}\right)$, which is 5 time higher then antioxidant activity of basil essential oil.

Accepted on Scientific Board on: $\quad 5^{\text {th }}$ March 2013

AS

Defended:

DE

Thesis Defend Board:

DB

president:

member:

member: 
Neizmernu zahvalnost dugujem svom mentoru prof. dr Zoranu Zekoviću za ogromnu podršku, znanje, strpljenje i pomoć koju mi je pružio tokom izrade $i$ pisanja doktorske disertacije.

Iskreno se zahvaljujem doc. dr Senki Vidović na nesebičnoj pomoći, sugestijama i razumevanju tokom izrade ovoga rada.

Zahvaljujem se koleginicama Biljani Marošanović i Maji Pandurević Todorović iz SP Laboratorije iz Bečeja na učešću u eksperimentalnom radu.

Najsrdačnije se zahvaljujem doc. dr Steli Jokić sa Prehrambeno tehnološkog fakulteta iz Osijeka i doc. dr Sandri Svilović sa Hemijsko-tehnološkog fakulteta u Splitu na pomoći i korisnim sugestijama tokom izrade doktorske disertacije.

Prof. dr Kirilu Lisičkovu i doc. dr Mariji Radojković zahvaljujem na korisnim savetima, podstreku, razmevanju i prijateljstvu.

Zahvalnost dugujem Slavici Ostojić, Jeleni Vladić, Aleksandri Cvetanović, Aleksandri Cvejin i Branimiru Pavliću na pomoći u eksperimentalnom radu, svakodnevnoj podršci, razumevanju i prijateljstuu.

Dragoj koleginici Stanislavi Sinđelić zahvaljujem na velikom razmevanju i pomoći kad god je to trebalo.

Zahvaljujem i svima onima koji su mi na bilo koji drugi način pomogli pri izradi ove disertacije.

Mojoj porodici, na neizmernoj ljubavi i razumevanju u ostvarivanju mojih želja i ambicija. 


\section{SADRŽAJ}

1. UVOD

2. OPŠTI DEO 3

2.1. BOSILJAK (Ocimum basilicum L.) 3

2.1.1. Morfološke karakteristike roda Ocimum 4

2.2. HEMIJSKI SASTAV 6

2.2.1. Monoterpeni 8

$\begin{array}{ll}\text { 2.2.2. Fenilpropani } & 10\end{array}$

2.2.3. Seskviterpeni 10

2.2.4. Fenolna jedinjenja 11

$\begin{array}{ll}\text { 2.2.5. Ostala jedinjenja } & 17\end{array}$

2.3. DEJSTVO I UPOTREBA 18

2.4. EKSTRAKCIJA FLUIDIMA U SUPERKRITIČNOM STANJU 19

2.4.1. Karakteristike fluida u superkritičnom stanju 21

2.4.2. Prednosti i nedostaci superkritične ekstrakcije (SFE) 24

2.5. MATEMATIČKO MODELOVANJE SUPERKRITIČNE EKSTRAKCIJE 26

2.5.1. Modeli zasnovani na diferencijalnom masenom bilansu (opšti model) 29

2.5.2. Jednostavan model baziran na kinetici prvog reda 30

2.5.3. Model neizreagovanog jezgra (MNJ) u poroznoj sferi 31

2.5.4. Modeli bazirani na mehanizmu desorpcije-rastvaranja-difuzije (DRD)

u poroznoj sferi 33

2.5.5. Pojednostavljenja modela 34

2.5.5.1. Modeli koji isključuju aksijalnu disperziju 34

2.5.5.2. Model u kojima je pogonska sila linearna 35

$\begin{array}{ll}\text { 2.5.5.3. Model pojedinačne sfere } & 37\end{array}$

2.5.5.4. Model karakterističnog vremena 39

2.5.6. Model pojedinačne ploče 39

2.5.7. Dvostepeni modeli 41

2.5.7.1. Sovová model $\quad 42$

2.5.7.2. Model koji je adaptirao Reverchon $\quad 45$

2.6. ANTIOKSIDANTI I ANTIOKSIDATIVNO DEJSTVO 46

3. REZULTATI I DISKUSIJA 49

3.1. ISPITIVANJE OSOBINA POLAZNOG MATERIJALA 49

3.2. GC/MS ANALIZA ETARSKOG ULJA BOSILJKA

3.3. EKSTRAKCIJA BOSILJKA SUPERKRITIČNIM UGLJENDIOKSIDOM 53

3.4. GASNO HROMATOGRAFSKA ANALIZA (GC/MS) EKSTRAKATA BOSILJKA

3.4.1. Soxhlet ekstrakcija $\quad 57$ 
3.4.2. Superkritična ekstrakcija $\quad 59$

3.4.2.1. Totalni (ukupni) ekstrakti 59

3.4.2.2. Ekstrakti dobijeni sukcesivnom (frakcionom) ekstrakcijom 65

3.5. OPTIMIZACIJA EKSTRAKCIJE BOSILJKA METODOM

ODZIVNE POVRŠINE (RSM) 71

3.6. MATEMATIČKO MODELOVANJE SUPERKRITIČNE EKSTRAKCIJE $\begin{array}{ll}\text { BOSILJKA } & 75\end{array}$

3.7. ANTIOKSIDATIVNO DELOVANJE 80

4. EKSPERIMENTALNI DEO 83

4.1. Određivanje stepena usitnjenosti $\quad 84$

4.2. Određivanje sadržaja vlage $\quad 84$

4.3. Određivanje sadržaja etarskog ulja $\quad 84$

4.4. Određivanje ukupnih ekstraktivnih materija (Soxhlet ekstrakcija) 84

4.5. Ekstrakcija bosiljka ugljendioksidom u superkritičnom stanju 85

$\begin{array}{ll}\text { 4.6. Metod odzivne površine } & 87\end{array}$

4.7. Analiza $\mathrm{CO}_{2}$ ekstrakta bosiljka primenom GC-MS(FID) 90

4.8. Matematičko modelovanje kinetike ekstrakcije bosiljka superkritičnim $\mathrm{CO}_{2} \quad 90$

4.9. Određivanje antioksidativne aktivnosti DPPH metodom 91

5. ZAKLJUČCI 93

6. LITERATURA 96

$\begin{array}{ll}\text { 7. PRILOZI } & 107\end{array}$ 


\section{LISTA OZNAKA, SKRAĆENICA I SIMBOLA}

\section{OZNAKE}

\begin{tabular}{|c|c|c|}
\hline$A_{13}$ & parametar u modelu (26), koji se računa prema izrazu (30) & \\
\hline$a_{t}$ & specifična površina čestica u ekstraktoru & $\mathrm{m}^{2} / \mathrm{m}^{3}$ \\
\hline$A_{E}$ & površina sloja punjenja materijala u ekstraktoru & $\mathrm{m}^{2}$ \\
\hline$a_{t}$ & specifična površina čestica u ekstraktoru & $\mathrm{m}^{2} / \mathrm{m}^{3}$ \\
\hline$b$ & podesiv parametar & $\mathrm{s}$ \\
\hline$b_{1}$ & $\begin{array}{l}\text { parametar u kvadratnoj jednačini (27) koji se računa prema } \\
\text { izrazu (28) }\end{array}$ & \\
\hline$c_{1}$ & $\begin{array}{l}\text { parametar u kvadratnoj jednačini (27) koji se računa prema } \\
\text { izrazu (29) }\end{array}$ & \\
\hline$c_{f}$ & koncentracija rastvorka u natkritičnom fluidu & $\mathrm{kg} / \mathrm{m}^{3}$ \\
\hline$c_{p}$ & $\begin{array}{l}\text { koncentracija rastvorka u natkritičnom fluidu unutar pora } \\
\text { čvrstog materijala }\end{array}$ & $\mathrm{kg} / \mathrm{m}^{3}$ \\
\hline$c_{p 0}$ & $\begin{array}{l}\text { početna koncentracija rastvorka u natkritičnom fluidu } \\
\text { unutar pora čvrstog materijala }\end{array}$ & $\mathrm{kg} / \mathrm{m}^{3}$ \\
\hline$c_{s}$ & $\begin{array}{l}\text { koncentracija rastvorka u čvrstoj fazi ili adsorbovanog na } \\
\text { čvrstoj fazi }\end{array}$ & $\mathrm{kg} / \mathrm{m}^{3}$ \\
\hline$\left.c_{S}\right|_{R}$ & $\begin{array}{l}\text { koncentracija rastvorka na spoljašnjoj površini čvrste } \\
\text { čestice }\end{array}$ & $\mathrm{kg} / \mathrm{m}^{3}$ \\
\hline$c_{s 0}$ & $\begin{array}{l}\text { početna koncentracija rastvorka adsorbovanog na čvrstoj } \\
\text { fazi }\end{array}$ & $\mathrm{kg} / \mathrm{m}^{3}$ \\
\hline$c_{\text {sat }}$ & koncentracija ulja u stanju zasićenja superkritičnog $\mathrm{CO}_{2}$ & $\mathrm{~kg} / \mathrm{m}^{3}$ \\
\hline$c_{v u 0}$ & početna koncentracija vezanog ulja u materijalu & $\mathrm{kg} / \mathrm{m}^{3}$ \\
\hline$D$ & koeficijent difuzije & $\mathrm{m}^{2} / \mathrm{s}$ \\
\hline $\mathrm{D}_{a x}$ & koeficijent difuzije u čvrstoj fazi & $\mathrm{m}^{2} / \mathrm{s}$ \\
\hline $\mathrm{D}_{a y}$ & koeficijent aksijalne disperzije & $\mathrm{m}^{2} / \mathrm{s}$ \\
\hline$D_{e}$ & $\begin{array}{l}\text { efektivni koeficijent difuzije rastvorka u čvrstom } \\
\text { materijalu }\end{array}$ & $\mathrm{m}^{2} / \mathrm{s}$ \\
\hline$D_{L}$ & $\begin{array}{l}\text { koeficijent aksijalne disperzije rastvorka u natkritičnom } \\
\text { fluidu }\end{array}$ & $\mathrm{m}^{2} / \mathrm{s}$ \\
\hline$F$ & masa čvrstog materijala & $\mathrm{kg}$ \\
\hline $\begin{array}{l}f r_{1}, f r_{2} \\
g_{1,2}\end{array}$ & $\begin{array}{l}\text { frakcije ekstrahovane supstance } \\
\text { parametri modela (26), koji se računa prema izrazu (27) }\end{array}$ & \\
\hline$h$ & aksijalna koordinata sloja punjenja u ekstraktoru & $\mathrm{m}$ \\
\hline$h_{E}$ & visina ekstraktora & $\mathrm{m}$ \\
\hline$H_{t}$ & visina sloja punjenja materijala u ekstraktoru & $\mathrm{m}$ \\
\hline$J$ & ukupna brzina ekstrakcije & $\mathrm{mol} / \mathrm{m}^{2} \mathrm{~s}$ \\
\hline$J(x, y)$ & tok prenosa mase na granici faza & $1 / \mathrm{s}$ \\
\hline$k$ & koeficijent brzine reakcije & $1 / \mathrm{s}$ \\
\hline$K$ & konstanta ravnoteže temperature i pritiska & \\
\hline $\begin{array}{c}k_{1}, k_{2} \\
\mathrm{~K}_{a d} \\
k_{d}\end{array}$ & $\begin{array}{l}\text { konstanta brzine u dva perioda difuzije } \\
\text { adsorpcijska konstanta ravnoteže } \\
\text { konstanta desorpcije }\end{array}$ & $1 / \mathrm{s}$ \\
\hline$k_{f}$ & $\begin{array}{l}\text { koeficijent prenosa mase u filmu natkritičnog fluida koji } \\
\text { okružuje česticu materijala, koeficijent prelaza mase ili } \\
\text { spoljašnji koeficijent prenosa mase }\end{array}$ & $\mathrm{m} / \mathrm{s}$ \\
\hline
\end{tabular}




\begin{tabular}{|c|c|c|}
\hline$k_{p}$ & kombinovani koeficijent prenosa mase & $\mathrm{m} / \mathrm{s}$ \\
\hline$k_{s}$ & koeficijent prenosa mase u čvrstoj fazi & $\mathrm{m} / \mathrm{s}$ \\
\hline $\mathrm{K}_{\mathrm{su}}$ & $\begin{array}{l}\text { koeficijent raspodele između slobodnog ulja u čvrstoj fazi i } \\
\text { rastvorenog ulja u fluidu }\end{array}$ & \\
\hline $\mathrm{K}_{\mathrm{vu}}$ & $\begin{array}{l}\text { koeficijent raspodele ulja između čvrste faze i rastvorenog } \\
\text { ulja u fluidu }\end{array}$ & \\
\hline$L$ & rastojanje & $\mathrm{m}$ \\
\hline $\mathrm{m}_{e p}$ & masa ekstrahovane supstance po jedinici površine & $\mathrm{kg} / \mathrm{m}^{2}$ \\
\hline$m_{f}$ & maseni protok $\mathrm{CO}_{2}$ & $\mathrm{~kg} / \mathrm{s}$ \\
\hline$m_{s}$ & masa materijala u ekstraktoru & $\mathrm{kg}$ \\
\hline$\dot{m}_{e p}$ & maseni protok fluida po jedinici površine & $\mathrm{kg} / \mathrm{sm}^{2}$ \\
\hline $\mathrm{n}_{\check{c} e s}$ & faktor oblika čestice (ploča $n=1$, valjak $n=2$, lopta $n=3$ ) & \\
\hline $\mathrm{Pc}$ & kritični pritisak & bar \\
\hline $\mathrm{q}$ & $\begin{array}{l}\text { specifična potrošnja rastvarača po jedinici mase } \\
\text { neekstraktibilnih komponenata materijala }\end{array}$ & $\mathrm{kg} / \mathrm{kg}$ \\
\hline$q$ & $\begin{array}{l}\text { specifična potrošnja rastvarača po jedinici mase } \\
\text { neekstraktibilnih komponenata materijala }\end{array}$ & $\mathrm{kg} / \mathrm{kg}$ \\
\hline$R$ & poluprečnik čestice materijala & $\mathrm{m}$ \\
\hline$r$ & radijalno rastojanje unutar čestice & $\mathrm{m}$ \\
\hline$r_{c}$ & poluprečnik jezgra & $\mathrm{m}$ \\
\hline$R_{p}$ & poluprečnik čestice & $\mathrm{m}$ \\
\hline$R_{p}$ & poluprečnik čestice & $\mathrm{m}$ \\
\hline$t$ & vreme & $\mathrm{s}$ \\
\hline$t_{i}$ & vreme unutrašnje difuzije & $\mathrm{s}$ \\
\hline $\bar{t}$ & vreme zadržavanja rastvarača u ekstraktoru & $\mathrm{s}$ \\
\hline Tc & kritična temperatura & ${ }^{\circ} \mathrm{C}$ \\
\hline$u$ & stvarna brzina rastvarača kroz sloj & $\mathrm{m} / \mathrm{s}$ \\
\hline$U$ & prividna brzina rastvarača kroz sloj & $\mathrm{m} / \mathrm{s}$ \\
\hline$u_{i}$ & brzina ekstrakcije & $\mathrm{m} / \mathrm{s}$ \\
\hline$u_{s}$ & brzina strujanja fluida & $\mathrm{m} / \mathrm{s}$ \\
\hline$V$ & zapremina ekstraktora & $\mathrm{m}^{3}$ \\
\hline$W$ & protok rastvarača & $\mathrm{kg} / \mathrm{s}$ \\
\hline$x$ & bezdimenzionalna koncentracija čvrste faze & \\
\hline$x_{0}$ & početni sadržaj rastvorljive supstance & $\mathrm{kg} / \mathrm{kg}$ \\
\hline$x_{\mathrm{f}}$ & $\begin{array}{l}\text { koncentracija rastvorljive supstance na površini čvrstih } \\
\text { čestica }\end{array}$ & $\mathrm{kg} / \mathrm{m}^{3}$ \\
\hline$x_{f}$ & $\begin{array}{l}\text { koncentracija rastvorljive supstance na površini čvrstih } \\
\text { čestica }\end{array}$ & $\mathrm{kg} / \mathrm{m}^{3}$ \\
\hline$y$ & bezdimenzionalna koncentracija fluidne faze & \\
\hline$y^{*}$ & rastvorljivost komponente $\mathrm{u}$ superkritičnom fluidu & $\begin{array}{l}\mathrm{kg} \text { supstance } / \mathrm{kg} \\
\mathrm{CO}_{2}\end{array}$ \\
\hline $\mathrm{Y}_{\mathrm{E}}$ & prinos ekstrakta & $\%$ \\
\hline$z_{\mathrm{w}}$ & $\begin{array}{l}\text { bezdimenziona koordinata granice između zone spore i } \\
\text { brze ekstrakcije }\end{array}$ & \\
\hline
\end{tabular}




\section{SIMBOLI}

\begin{tabular}{clc}
\hline$\alpha$ & parameter u jednačini & \\
$\beta$ & parameter u jednačini & \\
$\beta_{k}$ & vrednost svakog člana serije u jednačini (35) & \\
$\beta_{n}$ & pozitivni koren implicitne jednačine & $\mathrm{kg} / \mathrm{m}^{3}$ \\
$\delta$ & nasipna gustina & $\mathrm{m}$ \\
$\delta_{D}$ & debljina sloja difuzije & $\mathrm{m}$ \\
$\delta_{P}$ & debljina sloja čestica & $\mathrm{m}^{3} / \mathrm{m}^{3}$ \\
$\varepsilon$ & poroznost sloja materijala u ekstraktoru & $\mathrm{m}^{3} / \mathrm{m}^{3}$ \\
$\varepsilon_{p}$ & poroznost čestice materijala & $\mathrm{kg} / \mathrm{m}^{3}$ \\
$\rho$ & gustina CO 2 & $\mathrm{~kg} / \mathrm{m}^{3}$ \\
$\rho_{f}$ & gustina superkritičnog fluida & $\mathrm{kg} / \mathrm{m}^{3}$ \\
\hline$\rho_{s}$ & gustina čestica materijala & \\
\hline
\end{tabular}

\section{SKRAĆENICE}

\begin{tabular}{|c|c|}
\hline AARD & $\begin{array}{l}\text { srednja vrednost relativnog odstupanja podataka (eng. Average Absolute } \\
\text { Relative Deviation) }\end{array}$ \\
\hline ANOVA & analiza varijanse (eng. Analysis of variance) \\
\hline $\mathrm{C}$ & kompresor sa dijafragmom (eng. Compressor with diaphragm) \\
\hline $\mathrm{CU}$ & kompresorska jedinica (eng. Compressor unit) \\
\hline $\mathrm{CV}$ & nepovratni ventil (eng. Cut-off valve) \\
\hline $\mathrm{E}$ & ekstraktor (eng. Extractor) \\
\hline EO & etarsko ulje (eng. Essential oil) \\
\hline FI & merač protoka (eng. Flow indicator) \\
\hline FID & plameno jonizacioni detektor (eng. Flame Ionization Detector) \\
\hline $\mathrm{FP} / \mathrm{SSP}$ & $\begin{array}{l}\text { fluidno fazni/jednostavni model ploče (eng. Fluid Phase/Simple Single Plate } \\
\text { model) }\end{array}$ \\
\hline GC & gasna hromatografija (eng. Gas Chromatography) \\
\hline GRAS & generalno prihvaćen kao siguran (eng. Genarally recognised as safe) \\
\hline $\mathrm{HE}$ & izmenjuvač toplote (eng. Heat exchanger) \\
\hline MF & mikrofilter (eng. Micro filter) \\
\hline MS & masena spektrometrija (eng. Mass Sepctrometry) \\
\hline PI & instrument za merenje pritiska (eng. Pressure indicator) \\
\hline $\mathrm{RD}$ & sigurnosni disk (eng. Rupture disc) \\
\hline $\mathrm{RV}$ & regulacioni ventil (eng. Regulation valve) \\
\hline$S$ & separator (eng. Separator) \\
\hline $\mathrm{SC}$ & model neizreagovanog jezgra (eng. Shrinking Core model) \\
\hline
\end{tabular}


model ploče (eng. Single Plate model)

SSM

model pojedinačne sfere (eng. Single Sphere Model)

SSP

model pojedinačne ploče (eng. Single Simple Plate model)

TI

instrument za merenje temperature (eng. Temperature indicator)

UT

ultratermostat (eng. Ultra thermostat)

V

ventil otvoren-zatvoren (eng. On-off valve) 


\section{UVOD}

Priroda je neiscrpna inspiracija čoveka, a prirodni proizvodi mogu naći odgovor na skoro sve njegove potrebe. Lekovite biljke od davnina privlače čovekovu pažnju. U svim vremenima i u različitim kulturama širom sveta ljudi su koristili biljke kao lekovito sredstvo. Farmaceutska industrija koristi ih kao sirovine za izolovanje čistih prirodnih supstanci. Pored neospornog značaja za farmaceutsku industriju, prirodni proizvodi biljaka nalaze široku primenu u proizvodnji dijetetskih suplemenata, koji pored zadovoljavajućih nutritivnih svojstava, ispoljavaju određene farmakološke i fiziološke efekte na zdravlje ljudi.

U poslednjih nekoliko godina svetska naučna javnost ponovo se usmerava na istraživanja prirodnih supstanci kao novih lekova i fitoterapiju. Vodeća u proizvodnji i potrošnji fitopreparata je Nemačka, a slična situacija je u Francuskoj, Velikoj Britaniji i SAD. Zahvaljujući savremenim tehnologijama prerade lekovitog bilja, obezbeđeno je maksimalno iskorišćenje biljne sirovine i dobijanje krajnjeg proizvoda standardizovanog kvaliteta.

Ekstrakcija superkritičnim fluidima je inovativna tehnologija i pruža široke mogućnosti u izolovanju biološki aktivnih komponenata. Superkritična ekstrakcija se izvodi na umerenim temperaturama, što pogoduje izolovanju termolabilnih i lakoisparljivih supstanci, a primenjeni ekstragens $\left(\mathrm{CO}_{2}\right)$ ima oznaku GRAS (eng. Generally recognized as safe), pa se smatra potpuno sigurnim za primenu u prehrambenoj industriji. Ovim postupkom omogućena je visoka selektivnost i regulisanje sastava i prinosa dobijenih ekstrakata. Iz tih razloga ovaj postupak ekstrakcije se intenzivno primenjuje u prehrambenoj, farmaceutskoj i kozmetičkoj industriji.

Bosiljak Ocimum basilicum L. je najzastupljenija vrsta porodice usnatica (Lamiaceae). Familija Lamiaceae obuhvata 3500 vrsta distribuiranih između rodova kao zeljaste biljke, ponekad grmlje, a retko kad drveće, sa značajnim sadržajem etarskog ulja.

Već nekoliko hiljada godina ljudi širom planete koriste lekovitost bosiljka. Ova prijatna i aromatična biljka spada u omiljenu biljnu vrstu kod nas. Najčešća je primena $u$ obliku čajeva, čajnih mešavina, etarskog ulja, tečnih ekstrakata i prvenstveno kao začin. Etarsko ulje bosiljka ima antiseptično, antiinflamatorno, antimikrobno i antivirusno delovanje, a u industriji parfema predstavlja dragoceni proizvod. Zbog toga su istraživanja etarskog ulja i ekstrakata bosiljka $\mathrm{i}$ danas aktuelna $\mathrm{s}$ obzirom na široku primenu ovih proizvoda $\mathrm{u}$ prehrambenoj, farmaceutskoj i kozmetičkoj industriji. 
U okviru ove doktorske disertacije ispitana je ekstrakcija bosiljka (Ocimum basilicum L.) hidrodestilacijom, metilen-hloridom i ugljendioksidom u superkritičnom stanju. Variranjem parametara ekstrakcije (pritiska, temperature i gustine ekstragensa) pri konstantnom protoku, vremenu ekstrakcije i granulaciji čestica, praćena je kinetika ekstrakcije. Sukcesivnom superkritičnom ekstrakcijom, takođe, uz variranje ekstrakcionih parametara (pritiska i temperature, tj. gustine $\mathrm{CO}_{2}$ ) ispitivana je kinetika i prinos izdvojenih frakcija. Ispitan je kvalitativni i kvantitativni sastav etarskog ulja i ekstrakata primenom GC/MS i GC/FID hromatografije. Na osnovu rezultata ispitivanja kinetike, izvršeno je modelovanje primenom tri modela: Kandiah i Spiro (1990), Brunner (1984), Esquivel i saradnici (1999). Analizirana je antioksidativna aktivnost dobijenih ekstrakta, praćenjem sposobnosti neutralizacije slobodnih radikala $\left(\mathrm{DPPH}^{\bullet}\right)$.

$\mathrm{Na}$ osnovu prethodnih istraživanja i naših rezultata, mogućnost primene ekstrakata bosiljka u fitopreparatima bi omogućilo intenzivniju upotrebu ove široko rasprostranjene i gajene lekovite i aromatične biljke. Takođe, ovo istraživanje, kao i radovi ovog tipa, doprinose boljem razumevanju fenomena prenosa mase u savremenom separacionom postupku, kakav je superkritična ekstrakcija. 


\section{OPŠTI DEO}

\subsection{BOSILJAK (Ocimum basilicum L.)}

Bosiljak (Ocimum basilicum L.) pripada familiji Lamiaceae i jedna je od najrasprostranjenijih i najčešće gajenih biljaka širom sveta, naročito u Aziji, Evropi i Severnoj Americi. Pradomovina bosiljka je Indija. Prema nekim starim zapisima na prostore srednje Evrope preneli su ga monasi u XII veku. Reč bosiljak potiče od grčke reči basilikon, što znači kraljevski i odražava poštovanje drevnih kultura prema ovoj biljci. Latinski naziv biljke (Ocimum basilicum) je izveden od ozein - mirisati i basileus - vladar, što bi u prevodu značilo vladar mirisa.

Taksonomija biljke bosiljak (O. basilicum L.) data je u tabeli 1.

Tabela 1. Taksonomija biljke Ocimum basilicum L.

\begin{tabular}{|l|c||}
\hline Regnum (carstvo): & Plantae \\
\hline \hline Divisio (razdeo): & Magnoliophyta \\
\hline \hline Clasis (klasa): & Magnoliopsida \\
\hline \hline Ordo (red): & Lamiales \\
\hline Familia (porodica): & Lamiaceae \\
\hline \hline Genus (rod): & Ocimum \\
\hline Species (vrsta): & O. basilicum \\
\hline
\end{tabular}

Bosiljak je jednogodišnja, zeljasta biljka. Cveta od juna do oktobra. Stabljike su visoke od 20 do $45 \mathrm{~cm}$, razgranate, gole. Listovi su rombični, na dugačkim drškama, jajoliki, ravnog ili nazubljenog oboda, zašiljeni na vrhu. Priperci su mnogo manji od listova, zeljasti, često crvenkasti (slika 1). Cvetovi su sa kratkom cvetnom drškom, sitni, po šest složeni u pršljenove koji su približeni na vrhu stabljika, i obrazuju cvast (slika 2). Čašica je jajasta, dvousnata, zelena. Krunica je crvenkasta ili bela, gornja usna je široka, tupa, deljena u četiri režnja, a donja je duža i ispupčena. Plodovi su orašice, jajaste i mrke. Koren se razvija iz primarnog klicinog korenka, a sa njega slabiji bočni korenovi. Cela biljka ima prijatan i aromatičan miris (Jančić, 2004). 


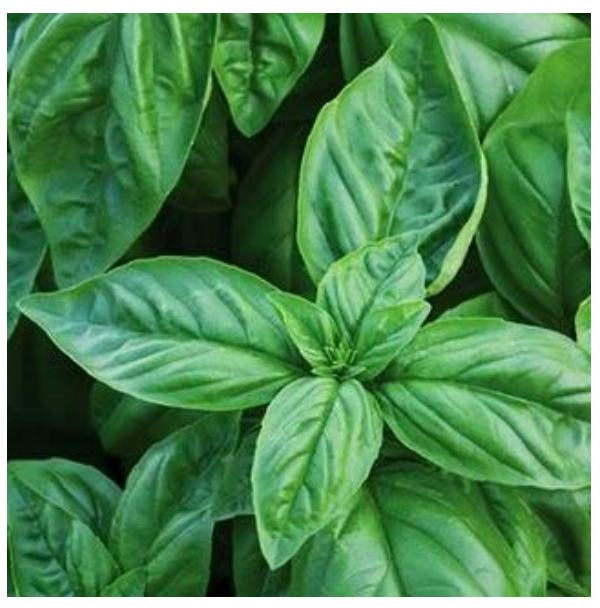

Slika 1. Stablo sa listovima

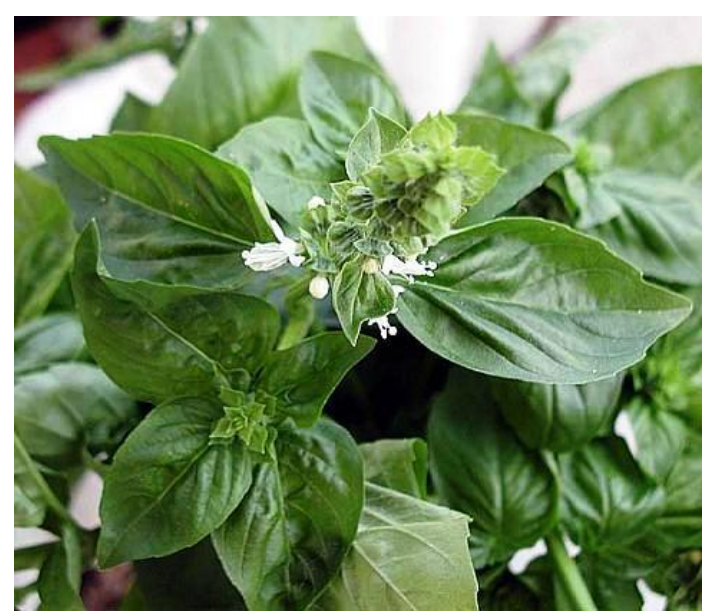

Slika 2. Cvast na vrhu stabljike

Sinonimi za bosiljak su: bažilek, bažulek, baselak, basiljak, basilje, bašelak, bosilak, bosilek, krupan bosiljak, bosilje, bazilek, bosiljak sarmaš, mirtela, veslođen, mislođen, fosliđen i dr. (Tucakov, 1990).

\subsubsection{Morfološke karakteristike roda Ocimum}

Rod Ocimum karakterišu velike razlike u morfologiji i hemotipu. Više od 50 biljnih vrsta i žbunova u tropskom i suptropskom regionu Azije, Afrike, Severne i Centralne Amerike pripada rodu Ocimum. Glavno mesto raznovrsnosti ove biljne vrste je Afrika (Paton, 1992). Morfološka raznolikost u okviru roda Ocimum ogleda se u obliku i veličini lista, veličini biljke i pigmentaciji. Geografsko područje, klima i način uzgajanja osim na morfologiju, utiče na aromu bosiljka koja može biti voćna, na limun, anis, kamfor i cimet. Taksonomiju bosiljka dodatno komplikuje postojanje brojnih biljnih vrsta i hemotipova $u$ okviru iste vrste, koje se ne razlikuju značajno u morfologiji. Hemotaksonomsku klasifikaciju sorti bosiljka dao je Darrah (1980) koji je O. basilicum klasifikovao u sedam grupa:

1. visoki i sitno listni bosiljak sa slatkom aromom,

2. široko listni, robusni bosiljak (nalik na zelenu salatu), naziva se i ,italijanski” bosiljak,

3. patuljasti tip, sa kratkim i malim listovima, tvz. „žbunasti” bosiljak,

4. kompaktni tip, opisan kao $O$. basilicum var. thyrsiflora, koji se često naziva „tajlandski” bosiljak,

5. purpurni bosiljak sa tradicionalnom slatkom aromom,

6. ljubičasti bosiljak „Dark Opal”, mogući hibrid između O. basilicum i O. forskolei, mirisa na karanfilić i 
7. Citriodorum tip, sa aromom limuna.

Većina komercijalnih sorti bosiljka na tržištu pripadaju vrsti $O$. basilicum. Na slici 3 su dati predstavnici pojedinih navedenih tipova bosiljka.

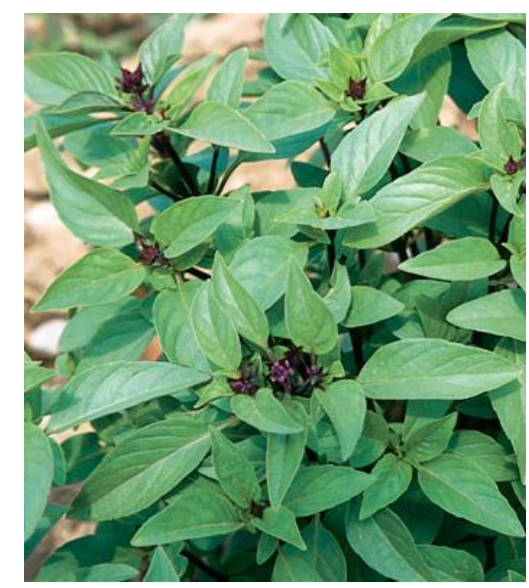

a)

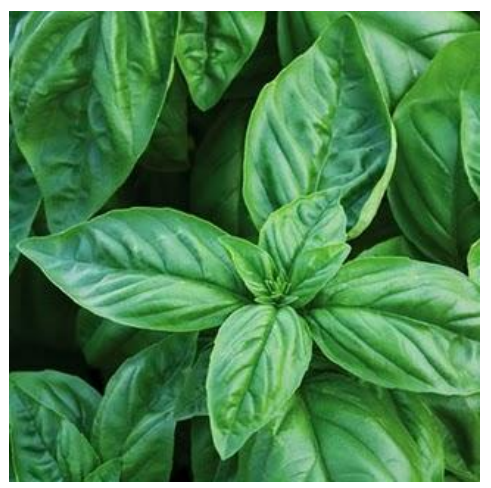

b)

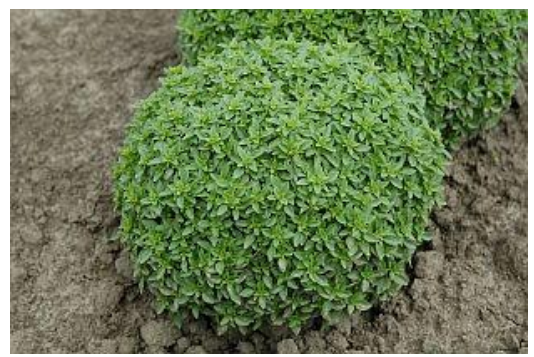

c)

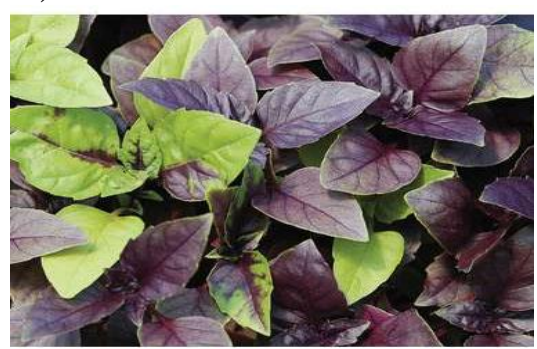

d)

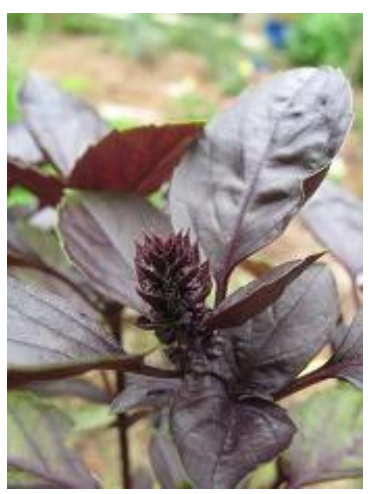

e)

Slika 3. Predstavnici Ocimum basilicum L.: a) O. basilicum var. thyrsiflora, „tajlandski” b) „italijanski”, c) ,žbunasti”, d) „Dark Opal” i e) purpurni bosiljak.

Najmanje 150 vrsta roda Ocimum se uzgaja u Aziji, Evropi i Severnoj Americi, među kojima su najznačajniji:

- Ocimum canum L.,

- Ocimum gratissimum L.,

- Ocimum citriodorum L.,
- Ocumum americanum L.,

- Ocimum santum L.,

- Ocimum klimandscharicum L.

Bosiljak je tipična začinska biljka mediteranskog podneblja poznata po aromi i lepoti listova koji mogu biti sitni ili krupniji, svetlo ili tamno zeleni, crvenosmeđi ili tamno ljubičasti. 


\subsection{HEMIJSKI SASTAV}

Prema svom hemijskom sastavu bosiljak pripada aromatičnim biljkama čiji se kvalitet ceni prema sadržaju etarskog ulja kojeg u herbi ima 0,5 - 0,8\% (Tucakov, 1990). Etarsko ulje sadrži oko 30 karakterističnih komponenata, terpene (monoterpeni i seskviterpeni, kao i njihovi oksidovani derivati) i fenolna jedinjenja. Dominantne komponente etarskog ulja su prvenstveno fenolna jedinjenja: metilhavikol (estragol), linalool, eugenol, metileugenol i metilcinamat. Postoji značajna razlika u sadržaju i hemijskom sastavu etarskog ulja zavisno od vrste i podneblja na kome se uzgaja bosiljak (tabela 2). Takođe, postoji ogromna varijacija u sadržaju komponenata u etarskom ulju. Na osnovu više od 200 analiza etarskih ulja bosiljka Lawrence (1988) je utvrdio 4 hemotipa etarskog ulja: metilhavikolski, linaloolski, metileugenolski, metilcinamatni, kao i brojne subtipove. Novija istraživanja hemijskog sastava etarskog ulja bosiljka na Tajlandu (Pripdeevech i sar., 2010), Kolumbiji (Vina i Murillo, 2003) i Indiji (Jirovetz i sar., 2003) pokazuju bitne razlike u hemijskom sastavu etarskih ulja dobijenih iz $O$. basilicum, O. americanum, $O$. gratissimum i $O$. sanctum.

Tabela 2. Hemotaksonomska klasifikacija O. basilicum na osnovu geografskog porekla

\begin{tabular}{|c|c|c|}
\hline Hemotip & Glavne komponente & Geografsko poreklo \\
\hline Evropski & linalool, metilhavikol & $\begin{array}{c}\text { Francuska, Italija, Egipat, } \\
\text { Mađarska, Južna Afrika, SAD }\end{array}$ \\
\hline Reunion & metilhavikol & $\begin{array}{c}\text { Ostrvo Komoro, Tajland, } \\
\text { Vijetnam, Sejšeli, Madagaskar }\end{array}$ \\
\hline Tropski & metilcinamat & $\begin{array}{c}\text { Bugarska, Indija, Gvatemala, } \\
\text { Pakistan }\end{array}$ \\
\hline Java & eugenol & $\begin{array}{c}\text { Indonezija, Severna Afrika, } \\
\text { Rusuja }\end{array}$ \\
\hline
\end{tabular}

Hemotipovi bosiljka su poznati i po geografskom poreklu kao egipatski, francuski, evropski ili reunion. Evropski hemotip bosiljka poseduje najkvalitetniju aromu i kao glavne komponente sadrži linalool i metilhavikol, a u manjoj meri 1,8-cineol, $\alpha$-pinen, $\beta$-pinen, mircen, terpinolen, kamfor, terpinen-4-ol, $\alpha$-terpineol, eugenol i seskviterpene (Guenther 1949; Simon i sar., 1990). Egipatski bosiljak je veoma sličan Evropskom, ali sadrži veći procenat metilhavikola (Fleischer 1981). Nasuprot tome, bosiljak sa ostrva Komoro sadrži malo ili nimalo linaloola, sa oštrijim začinskim mirisom, veoma visokim sadržajem metilhavikola i manjim sadržajem 1,8-cineola, borneola, kamfora i eugenola (Lawrence i sar., 1972; Simon i sar., 1984). Bosiljak iz Bugarske, Indije, Gvatemale i Pakistana (Marotti i sar., 
1996) sadrži veliki procenat metilcinamata, dok je bosiljak iz Rusije, Jave i Severne Afrike sa visokim sadržajem eugenola.

U tabeli 3 je prikazan hemijski sastav etarskog ulja dobijenog hidrodestilacijom različitih varijeteta $O$. basilicum L. sa različitog geografskog područja (Suppakul i sar., 2003).

Tabela 3. Hemijski sastav etarskog ulja O. bacilicum L.

\begin{tabular}{|c|c|c|}
\hline Zemlja porekla & Hemijski sastav $(\%, \mathrm{~m} / \mathrm{m})$ & Referenca \\
\hline $\begin{array}{l}\text { Benin } \\
\text { „metilhavikol“ } \\
\text { „metilhavikol-linalool“ } \\
\text { „linalool-eugenol“ }\end{array}$ & $\begin{array}{l}\text { metilhavikol (>65) } \\
\text { metilhavikol (55), linalool (20-30) } \\
\text { linalool (42-45), eugenol (15), } \\
\text { sa ili bez trans- } \alpha \text {-bergamotena (6-15) }\end{array}$ & Yayi i sar., 2001 \\
\hline $\begin{array}{l}\text { Brazil } \\
\text { „linalool“ } \\
\text { „1,8-cineol“ } \\
\text { „metilhavikol“ } \\
\text { „metilcinamat““ }\end{array}$ & $\begin{array}{l}\text { linalool }(49,73) \\
1,8 \text {-cineol }(22) \\
\text { metilhavikol }(47) \\
\text { metilcinamat }(65,5)\end{array}$ & Vieira and Simon, 2000 \\
\hline Kamerun & $\begin{array}{l}\text { linalool }(50,8) \text {, eugenol }(13,5) \text {, limonen }(10,4) \text {, } \\
1,8 \text {-cineol }(3,1)\end{array}$ & Zollo i sar., 1998 \\
\hline Kuba & $\begin{array}{l}\text { metilhavikol }(66,75), 1,8 \text {-cineol }(5,44) \text {, linalool }(4,95) \text {, } \\
\alpha \text {-bisabolen }(3,60), \alpha \text {-bergamoten }(2,96)\end{array}$ & Pino i sar., 1993 \\
\hline Nemačka & metilhavikol $(86,1)$ & Baratta i sar., 1998 \\
\hline Italija & & Marotti i sar., 1996 \\
\hline „linalool“ & linalool (70), 1,8-cineol (13) & \\
\hline „linalool-metilhavikol“ & linalool (41-60), metilhavikol (18-41), 1,8-cineol (2-6) & \\
\hline „linalool-eugenol“ & linalool (61-76), eugenol (4), 1,8-cineol (1-11) & \\
\hline „eugenol“, nizak linalool & eugenol $(2,22-3,89)$, linalool $(60,76-64,14)$ & \\
\hline „eugenol“, visok linalool & eugenol $(1,99)$, linalool $(69,06-76,20)$ & \\
\hline Mongolija & metilhavikol (52), linalool $(23,8), \tau$-kadinol $(4,4)$ & Shartar and Altantsetseg, 2000 \\
\hline Gvineja & linalool (69), eugenol (10), $\alpha$-bergamoten (3), timol (2) & Keita i sar., 2000 \\
\hline Somalija & dihidrotageton $(>80)$ & Ruberto i sar., 1991 \\
\hline Tajland & metilhavikol i $\alpha$-humulen $(88,2)$ & Lawrence i sar., 1972 \\
\hline Reunion & metilhavikol (84-89) & Sanda i sar., 1998 \\
\hline Evropa & linalool (41), metilhavikol (22), & \\
\hline Turska & $\begin{array}{l}\text { linalool (17-24), metil-(E)-cinamat (12-16), 1,8-cineol } \\
\text { (7-13), } \tau \text {-kadinol (5-7) }\end{array}$ & Ozek i sar., 1995 \\
\hline
\end{tabular}


Etarska ulja su smeše isparljivih, lipofilnih sastojaka, koje se sintetišu i lokalizuju u specijalnim sekretornim strukturama biljaka. Mogu biti lokalizovane endogeno (uljne ćelije, sekretorne šupljine i sekretorni kanali) i egzogeno (žlezdane dlake i osmofore). Etarska ulja kao „sekundarni metaboliti“ su veoma važni za opstanak biljke, služe kao „biljni feromoni“ za privlačenje polinatora i odbijanje štetnih insekata, odbijanje grabljivica i štite biljku od mikroorganizama i bolesti.

Etarsko ulje bosiljka je žute do naradžaste boje, sa prijatnim, slatkim mirisom koji pripada srednjoj mirisnoj noti za koje je karakteristično da je umereno isparljiva. Umiruje ili stimuliše varenje, smanjuju napetost, odličan je antiseptik za gornje respiratorne organe. Zbog svoje arome, etarsko ulje bosiljka je izuzetno cenjeno u parfimerijskoj industriji. Na svetskom tržištu nalazi se nekoliko tipova etarskih ulja bosiljka koji se razlikuju po hemijskom sastavu (hemotipu), kompoziciji i mirisu.

\subsubsection{Monoterpeni}

Linalool je tercijarni monoterpenski alkohol, izomeran geraniolu. Nalazi se u etarskim uljima ruže, narandže, lavande, bosiljka, korijandera i dr. Čist linalool miriše na đurđevak. Linalool je jedan od najvažnijih monoterpena u kozmetičkoj industriji, jer se koristi u proizvodnji sapuna i deterdženata. U etarskom ulju bosiljka može biti zastupljen u velikom procentu (45 $65 \%)$, i ima antimikrobnu aktivnost.

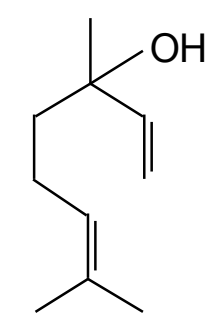

Linalool

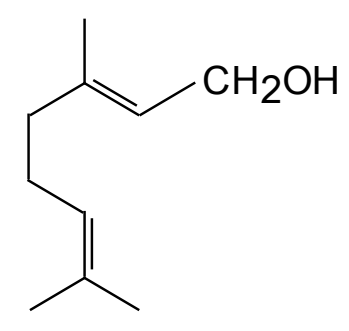

Geraniol

Slika 4. Strukturna formula linaloola i geraniola $\left(\mathrm{C}_{10} \mathrm{H}_{18} \mathrm{O}\right)$

U prirodi linalool se nalazi u dva stereoizomerne forme: likareol (R)-(-)-linalool i koriandrol $(S)-(+)$-linalool. U etarskom ulju bosiljka prisutan je enantiomer $(R)$-linalool koji obezbeđuje drvenasto kamfornu notu, dok se $(L)$-oblik karakteriše slatko-cvetnom mirisnom notom. 
Geraniol je monoterpenski alkohol, bezbojno ili bledožuto ulje, nerastvorno u vodi, a rastvorljivo u većini organskih rastvarača. Mirisa je na ružu i često se upotrebljava u industriji parfema. Geraniol i nerol su dva cis-trans $(Z, E)$ izomerna nezasićena alkohola. U etarskom ulju bosiljka nalazi se u manjem procentu.

Limonen je ciklični terpen. To je bezbojna tečnost na sobnoj temperaturi, sa izuzetno jakim mirisom pomorandže. Limonen ima jedan asimetrični centar, a u prirodi se javlja kako u obliku enantiomera, tako i u obliku racemata. U etarskom ulju bosiljka nalazi se u malom procentu.

$\boldsymbol{\alpha}$-Terpineol je nezasićeni monociklični alkohol. Slabo obojena tečnost, mirisa na ljiljan. Dominantna komponenta je u borovom ulju. Javlja se u obliku tri izomera $(\alpha, \beta$ i $\gamma)$, pri čemu je $\alpha$-terpineol najzastupljeniji. Rastvara se $u$ organskim rastvaračima, ali ne $i \mathrm{u}$ vodi. Upotrebljava se u medicini, parfimeriji, kozmetičkoj industriji, a kao antioksidant $\mathrm{u}$ prehrambenoj industiji.

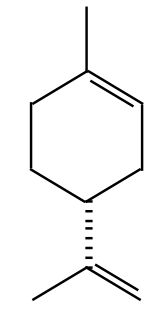

Limonen

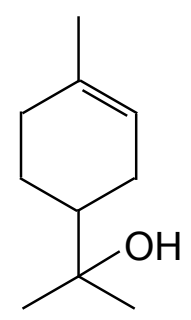

$\alpha$-Terpineol

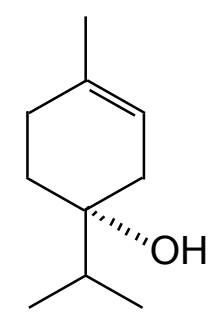

Terpinen-4-ol

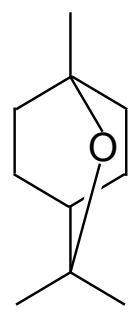

1,8-Cineol

Slika 5. Strukturne formule komponenata etarskog ulja bosiljka

Terpinen-4-ol pripada grupi nezasićenih monocikličnih alkohola. Bezbojna ili slabo žuto obojena tečnost. Pokazuje antioksidativno dejstvo i koristi se kao antiseptik.

1,8-Cineol je bezbojna tečnost. Monoterpen ciklične etarske strukture. Pored glavnih komponenti dosta je zastupljen u etarskom ulju bosiljka. Ima veliki broj sinonima, a najpoznatiji je eukaliptol, jer je on dominantna komponenta u etarskom ulju eukaliptusa. Miris je sličan kamforu, izaziva rashalađujući osećaj u ustima. Zbog prijatnog mirisa koristi se u parfimerijskoj industriji i farmaceutskim proizvodima. Koristi se i kao snažan insekticid. 


\subsubsection{Fenilpropani}

Eugenol $\left(\mathrm{C}_{10} \mathrm{H}_{12} \mathrm{O}_{2}\right)$ je derivat fenil propanoida. Udeo eugenola u etarskom ulju bosiljka se kreće od 8 do $10 \%$. To je žuta, masna tečnost, izolovana iz mnogih etarskih ulja. Delimično je rastvoran u vodi, a potpuno je rastvorljiv u organskim rastvaračima. Ima prijatnu, ljutkastu aromu, nalik karanfiliću, koji utiče na prijatnu arome čitave biljke i etarskog ulja.

Koristi se u preparatima za privlačenje insekata, deluje kao UV-absorbens, analgetik, antiseptik, antioksidant i kao stabilizator za plastiku i gumu. Eksperimentalna istraživanja pokazala su da eugenol deluje i kao anestetik, miorelaksant, tj. poseduje antikonvulzivno dejstvo (Dallmeier i Carlini, 1981). Primenjuje se u parfimeriji, a u farmaceutskoj industriji kao korigens ukusa.

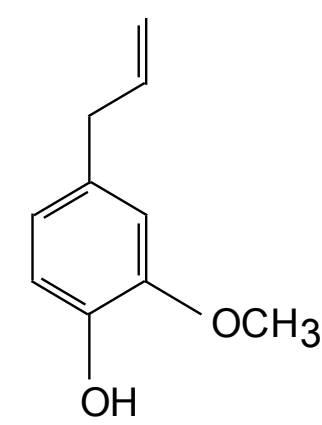

Eugenol<smiles>C=CCc1ccc(OC)cc1</smiles>

metil-havikol

Slika 6. Strukturne formule eugenola i metil-havikola

Metil-havikol (estragol) je prirodna organska komponenta. To je bezbojna do bledo žuta tečnost. U etarskom ulju bosiljka sadržaj varira od 23 do $88 \%$. Ispitivanjem na eksperimentalnim životinjama potvrđeno je da estragol ima kancerogeno i teratogeno dejstvo, dok kod ljudi trenutno ne postoje dokazi za kancerogeno dejstvo.

\subsubsection{Seskviterpeni}

$\boldsymbol{\beta}$-Elemen sastoji se od tri izoprenske jedinice. Postoji 4 izomera elemena $(\alpha, \beta, \gamma$ i $\delta$ ) koji doprinose cvetnoj aromi nekih biljka. Nalazi se u celeru, menti i drugim lekovitim biljkama. Posebnu pažnju naučne javnosti $\beta$-elemen privlači zbog svog antikancerogenog dejstva na većinu tumorskih ćelija.

$\boldsymbol{\alpha}$-Humulen ( $\boldsymbol{\alpha}$-kariofilen) je glavni sastojak etarskog ulja hmelja. 


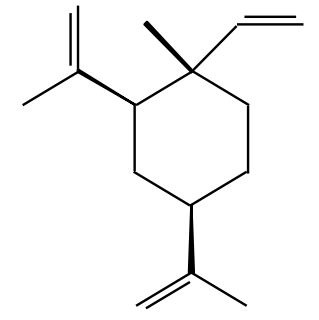

$\beta$-Elemen

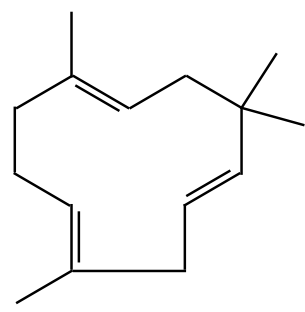

$\alpha$-Humulen<smiles>C=C1/C=C/C(C(C)C)CC/C=C(/C)CCC1</smiles>

Germakren D

Slika 7. Strukturne formule komponenata etarskog ulja bosiljka

Germakren D je lako isparljivo organsko jedinjenje koje se nalazi u većini biljaka. Ispoljava antimikrobno i insekticidno svojsvo.

$\boldsymbol{\gamma}$-Kadinen i $\boldsymbol{\delta}$-kadinen pripadaju grupi bicikličnih seskviterpena. To su izomeri koji su prisutni u velikom broju etarskih ulja i aromatičnim biljnim vrstama.<smiles>C=C1CCC(C(C)C)C2C=C(C)CC[C@H]12</smiles>

$\gamma$-Kadinen<smiles>CC1=CC2C(C)=CCCC2C(C(C)C)CC1</smiles>

$\delta$-Kadinen<smiles>C=C(C)C1CCC2(C)CCCC(=C)[C@H]2C1</smiles>

$\beta$-Selinen

Slika 8. Strukturne formule komponenata etasrkog ulja bosiljka

$\boldsymbol{\beta}$-Selinen je biciklični seskviterpen koji pripada grupi eudesmana. Izolovan je iz etarskog ulja celera.

\subsubsection{Fenolna jedinjenja}

Fenolna jedinjenja predstavljaju široko rasprostranjenu grupu heterogenih jedinjenja i jednu od najvažnijuh klasa prirodnih antioksidanata. To su supstance koje se sastoje od jednog ili više aromatičnih prstenova sa jednom ili više hidroksilnih grupa, pa se mogu svrstati u sledeće klase jedinjenja: fenolne kiseline, flavonoide, stilbene, kumarine i tanine (Liu, 2004). Većina ovih jedinjenja se u biljkama nalazi u konjugovanim oblicima, najčešće su vezani za šećernu komponentu (glukoza, ramnoza, ksiloza, galaktoza, arabinoza) preko jedne ili više fenolnih grupa, pa su iz tog razloga rastvorna u vodi. Aglikonska komponenta je odgovorna za biološku aktivnost. 
U biljnim organizmima polifenolna jedinjenja obavljaju niz funkcija: deluju kao antimikrobni agensi, antioksidanti, fotoreceptori, atraktanti insekata važnih za oprašivanje, repelenti za herbivore ili kao zaštita biljnih tkiva od prekomernog UV-zračenja (Heim i sar., 2002). Kao prirodni izvori polifenolnih jedinjenja najznačajniji su začinsko i lekovito bilje, međutim, izvori mogu biti i žitarice, seme uljarica, voće, povrće i mikrobiološki produkti (Naczk i Shahidi, 2006).

Polifenolna jedinjenja se smatraju vodećim jedinjenjima sa antioksidativnim delovanjem. Deluju kao redukujući agensi, skevindžeri singletnog kiseonika, antioksidanti donori vodonika, i imaju sposobnost heliranja metala.

Od polifenolnih jedinjenja koja su zastupljena u $O$. basilicum izdvajaju se fenolne kiseline i flavonoidi.

\section{Fenolne kiseline}

Fenolne kiseline obuhvataju hidroksi i druge funkcionalne derivate benzoeve kiseline $\left(\mathrm{C}_{6}-\mathrm{C}_{1}\right)$ i cimetne kiseline $\left(\mathrm{C}_{6}-\mathrm{C}_{3}\right)$ (Rice-Evans i Packer, 2003) (slika 9). Ova jedinjenja učestvuju u rekciji otpuštanja vodonikovog atoma i reakcijama „hvatanju“ slobodnih radikala. Cuvelier i saradnici (1992) potvrdili su da su polifenolne kiseline efikasniji antioksidanti od monofenolnih. Antioksidativnost raste sa povećanjem broja hidroksilnih grupa, pa derivati dihidroksibenzoeve kiseline imaju veću antioksidativnu aktivnost $u$ odnosu na derivate hidroksibenzoeve kiseline. Monohidroksibenzoeve kiseline sa hidroksilnom grupom u orto i para položaju imaju značajnije manju antioksidativnu aktivnost u odnosu na hidroksilnu grupu u meta položaju. Utvrđeno je da je za antioksidativno dejstvo fenolnih kiselina značajno prisustvo kateholne jedinice. Galna kiselina kao 3,4,5-trihidroksibenzoeva kiselina, ima jače antioksidativno delovanje od derivata dihidroksibenzoeve kiseline, što je u skladu sa prethodnom tvrdnjom.

a)

\begin{tabular}{llll}
\hline \multirow{2}{*}{ Derivati benzoeve kiseline } & \multicolumn{3}{c}{ Supstituenti } \\
\cline { 2 - 4 } & $\mathrm{R}_{1}$ & $\mathrm{R}_{2}$ & $\mathrm{R}_{3}$ \\
\hline Benzoeva kiselina & $\mathrm{H}$ & $\mathrm{H}$ & $\mathrm{H}$ \\
\hline$p$-Hidroksibenzoeva kiselina & $\mathrm{H}$ & $\mathrm{OH}$ & $\mathrm{H}$ \\
\hline Protokatehinska & $\mathrm{H}$ & $\mathrm{OH}$ & $\mathrm{OH}$ \\
\hline Vanilinska & $\mathrm{CH}_{3}$ & $\mathrm{OH}$ & $\mathrm{H}$ \\
\hline Siringinska & $\mathrm{CH}_{3}$ & $\mathrm{OH}$ & $\mathrm{CH}_{3}$ \\
\hline Galna & $\mathrm{OH}$ & $\mathrm{OH}$ & $\mathrm{OH}$ \\
\hline
\end{tabular}


b)

\begin{tabular}{llll}
\hline \multirow{2}{*}{ Derivati cimetne kiseline } & \multicolumn{3}{c}{ Supstituenti } \\
\cline { 2 - 4 } & $\mathrm{R}_{1}$ & $\mathrm{R}_{2}$ & $\mathrm{R}_{3}$ \\
\hline Cimetna kiselina & $\mathrm{H}$ & $\mathrm{H}$ & $\mathrm{H}$ \\
\hline$p$-Kumarinska kiselina & $\mathrm{H}$ & $\mathrm{OH}$ & $\mathrm{H}$ \\
\hline Kafena kiselina & $\mathrm{OH}$ & $\mathrm{OH}$ & $\mathrm{H}$ \\
\hline Ferulna kiselina & $\mathrm{CH}_{3}$ & $\mathrm{OH}$ & $\mathrm{H}$ \\
\hline Sinapinska kiselina & $\mathrm{CH}_{3}$ & $\mathrm{OH}$ & $\mathrm{CH}_{3}$ \\
\hline
\end{tabular}

Slika 9. Struktura fenolnih kiselina: a) derivati benzoeve kiseline i b) derivati cimetne kiseline<smiles>O=C(/C=C/c1ccc(O)c(O)c1)O[C@H](C(=O)O)[C@@H](O)C(=O)O</smiles>

a)

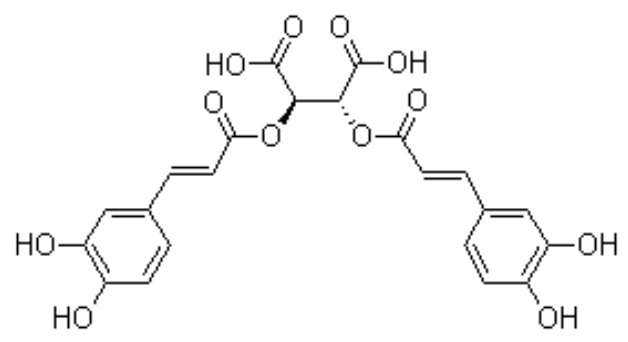

b)

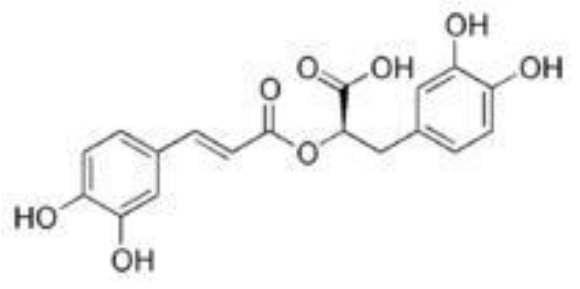

c)

Slika 10. Strukture fenolnih kiselina: a) kaftarinska, b) cikori i c) rozmarinska kiselina

Najčešće prisutne fenolne kiseline koje su izolovane iz O. basilicum su cimetna kiselina, kafena, vanilinska, hidroksibenzoeva kiselina, ferulna, sinapinska, kaftarinska, cikori i rozmarinska kiselina (Lee i Scagel, 2009, Jayasinghe i sar., 2003). Najzastupljenija kiselina u svim ispitivanim uzorcima bosiljka bila je rozmarinska kiselina (slika 10). Kaftarinska kiselina predstavlja estar kafene i vinske kiseline. Nalazi se u grožđu i smatra se da utiče na žutu boju grožđa i vina. Cikori kiselina se sastoji od dva molekula kafene kiseline esterifikovane vinskom kiselinom. Predstavlja dominatnu fenolnu kiselinu izolovanu iz biljke Echinacea purpurea (Molgaard i sar., 2003), stimuliše fagocitozu, štiti kolagen od dejstva slobodnih radikala i inhibira HIV virus. Značajne količine ove kiseline nalaze se još u matičnjaku, bosiljku, maslačku i akvatičnim biljkama (alge i morska trava). Rozmarinska kiselina predstavlja estar kafene kiseline i 3,4-dihidroksifenil-2`-hidroksipropanske kiseline. Prisutna je u većini biljaka familije Lamiaceae, u ruzmarinu, origanu, žalfiji, timijanu i menti. Ima snažno antioksidativno, antimikrobno, antivirusno i antiinflamatorno dejstvo. Na razlike 
u sadržajima fenolnih kiselina utiče varijetet, uslovi okline, tip zemljišta i klimatski uslovi (Javanmardi i sar., 2002).

\section{Flavonoidi}

Flavonoidi su najveća grupa fenolnih jedinjenja, oko polovine fenolnih jedinjenja koja se javlja kod biljaka su flavonoidi (Harborne i sar., 1999). Osnovni strukturni skelet flavonoida sačinjava 15 atoma ugljenika u osnovnoj strukturi $\left(\mathrm{C}_{6}-\mathrm{C}_{3}-\mathrm{C}_{6}\right)$, od kojih devet pripada benzopiranskom prstenu (benzenski prsten A kondenzovan sa piranskim prstenom C). Preostalih šest ugljenikovih atoma čine benzenski prsten B (slika 11).

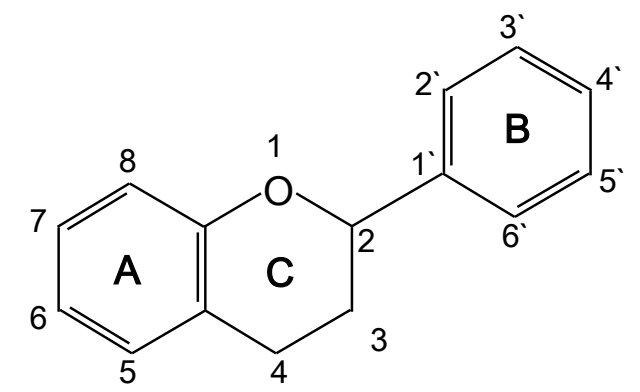

Slika 11. Osnovna struktura flavonoida

$\mathrm{Na}$ osnovu supstitucionog profila heterocikličnog prstena i pozicije aromatičnog prstena B razlikuje se dvanaest podgrupa flavonoida. Sekundarni (B) prsten može da bude u položaju 2 (flavoni, flavonoli, flavononi, dihidroflavoni, katehini, flavani i antocijanidini), 3 (izoflavonoidi) ili 4 (neoflavoni). U nekoliko slučajeva, šestočlani heterociklični prsten se javlja u otvorenoj izomernoj formi (halkoni i dihidrohalkoni) ili je zamenjen petočlanim prstenom (auroni).

U prirodi se najčešće javljaju jedinjenja sa hidroksilnim grupama u B-3` i B-4 položaju, i nešto manje sa jednom hidroksilnom grupom u položaju B-4'. Većina flavonoida u prirodi se javlja u konjugovanoj formi, vezana za šećernu komponentu (O-glikozidi, a ređe C-glikozidi). Kao šećerna komponenta najčešće je prisutna glukoza, a ređe galaktoza, ramnoza i ksiloza (Herrmann, 1989).

Najrasprostranjeniji od svih flavonoida su flavonoli, koji imaju od 200-300 poznatih aglikona, i flavoni. Kvercetin, kamferol i mircetin su najzastupljeniji flavonoli, a od flavona luteolin i apigenin. Poznato je više od stotinu glikozida kvercetina.

Raznovrsnost i veliki broj struktura flavonoida rezultat su brojnih modifikacija njihovih osnovnih struktura, kao što su: hidroksilacije, O-metilacije hidroksilnih grupa, 
dimerizacije, vezivanje neorganskog sulfata, i najvažnije, glikolizacije hidroksilnih grupa (nastajanje O-glikozida) ili flavonoidnog jezgra (nastajanje C-glikozida).

Zbog svoje strukture flavonoidi su snažni prirodni antioksidanti i svoju aktivnost mogu da ispolje na više načina. Dovode do prekidanja slobodno-radikalskih reakcija, pri čemu predaju vodonikov atom radikalima i sami prelaze u slobodni radikal, koji se stabilizuje putem rezonantnih struktura. Antioksidativne osobine pokazuju i tako što inhibišu enzime odgovorne za produkciju superoksid anjona, heliranjem metala koji su uključeni u reakcije nastanka slobodnih radikala i prevencijom peroksidacije (Buhler i Miranda, 2000).

Flavoni<smiles>[R6]Oc1ccc(-c2cc(=O)c3c(O)c([R])c(O[R20])c([R3])c3o2)cc1[R4]</smiles>

\begin{tabular}{llllll}
\hline \multirow{2}{*}{ Jedinjenje } & \multicolumn{5}{c}{ Supstituenti } \\
\cline { 2 - 6 } & $\mathrm{R}_{1}$ & $\mathrm{R}_{2}$ & $\mathrm{R}_{3}$ & $\mathrm{R}_{4}$ & $\mathrm{R}_{5}$ \\
\hline Luteolin & $\mathrm{H}$ & $\mathrm{H}$ & $\mathrm{H}$ & $\mathrm{OH}$ & $\mathrm{H}$ \\
\hline Apigenin & $\mathrm{H}$ & $\mathrm{H}$ & $\mathrm{H}$ & $\mathrm{H}$ & $\mathrm{H}$ \\
\hline Nevadensin & $\mathrm{OCH}_{3}$ & $\mathrm{H}$ & $\mathrm{OCH}_{3}$ & $\mathrm{H}$ & $\mathrm{CH}_{3}$ \\
\hline Salvigenin & $\mathrm{OCH}_{3}$ & $\mathrm{CH}_{3}$ & $\mathrm{H}$ & $\mathrm{H}$ & $\mathrm{CH}_{3}$ \\
\hline
\end{tabular}

Flavonoli<smiles>[R]c1cc(-c2oc3cc(O)cc(O)c3c(=O)c2O)cc([R3])c1[R2]</smiles>

\begin{tabular}{llll}
\hline \multirow{2}{*}{ Jedinjenje } & \multicolumn{3}{c}{ Supstituenti } \\
\cline { 2 - 4 } & $\mathrm{R}_{1}$ & $\mathrm{R}_{2}$ & $\mathrm{R}_{3}$ \\
\hline Kamferol & $\mathrm{OH}$ & $\mathrm{H}$ & $\mathrm{H}$ \\
\hline Kvercetin & $\mathrm{OH}$ & $\mathrm{OH}$ & $\mathrm{H}$ \\
\hline Mircetin & $\mathrm{OH}$ & $\mathrm{OH}$ & $\mathrm{OH}$ \\
\hline
\end{tabular}

Slika 12. Hemijska struktura biljnih flavonoida

Flavonoidi koji su izolovani iz $O$. basilicum pripadaju podgrupi flavona i flavonola (slika 12). Istraživanja koja su vršili Grayer i saradnici (2002) pokazala su da su dominatne komponente iz grupe flavonola, kvercetin 3-O-rutinozid i kvercetin 3-O-glikozid. Kao prateći flavoni prisutni su: vicenin-2, luteolin 5-O-glukozid, luteolin 7-O-glukozid, apigenin 7-Oglukozid i kamferol 3-O-malonilglukozid. Upoređivanjem izolovanih flavonoida iz različitih 
vrsta Ocimum (O. americanum, O. citriodorum, O. minimum i O. basilicum), Vieira i saradnici (2003) i Grayer i saradnici (2004) uvrdili su da se hemijski sastav flavonoida razlikuje kvalitativno i kvantitativno u zavisnosti od genotipa bosiljka.

\section{Antocijani}

Antocijani su glikozidi antocijanidina, flavonoida koji su zaduženi za crvenu, ljubičastu i plavu boju voća i povrća. Nalaze se i u drugim delovima biljaka (list i cvet). Osnovna struktura antocijana je 2-fenilbenzopirijum ili flavilijum katjon (slika 13).<smiles></smiles>

\begin{tabular}{llll}
\hline \multirow{2}{*}{ Jedinjenje } & \multicolumn{3}{c}{ Supstituenti } \\
\cline { 2 - 4 } & $\mathrm{R}_{1}$ & $\mathrm{R}_{2}$ & $\mathrm{R}_{3}$ \\
\hline Pelargonidin & $\mathrm{H}$ & $\mathrm{OH}$ & $\mathrm{H}$ \\
\hline Cijanidin & $\mathrm{OH}$ & $\mathrm{OH}$ & $\mathrm{H}$ \\
\hline Delfinidin & $\mathrm{OH}$ & $\mathrm{OH}$ & $\mathrm{OH}$ \\
\hline Peonidin & $\mathrm{OCH}_{3}$ & $\mathrm{OH}$ & $\mathrm{H}$ \\
\hline Petunidin & $\mathrm{OCH}_{3}$ & $\mathrm{OH}$ & $\mathrm{OH}$ \\
\hline
\end{tabular}

Slika 13. Osnovna struktura antocijana

Svi antocijani imaju hidroksilnu grupu u položaju $3 \mathrm{C}$ prstena, dok se ostali supstituenti (hidroksilna ili metoksi grupa) nalaze u položajima 5 i 7 A prstena, i 3`, 4` i 5 ` B prstena. Na osnovu broja i položaja hidroksilnih grupa u B prstenu razlikuju se tri osnovna jedinjenja antocijanidina: pelargonidin, cijanidin i delfinidin, a metilovanjem hidroksilnih grupa nastaju: peonidin, petunidin i malvidin. Sve je veći interes za izolovanje i upotrebu antocijana, ne samo zbog toga što predstavljaju prirodne boje koje mogu zameniti sintetičke, već i zbog njihovih bioaktivnih osobina. Varijeteti bosiljka (,Dark Opal“ i O. basilicum var. purpurescens) sa purpurnim pigmentima predstavljaju značajan izvor antocijana (Simon i sar., 1999). Iz purpurnih listova ovih varijeteta izolovano je 11 antocijana sa cijanidin aglikonskom osnovom i 3 antocijana koji pripadaju peonidinu (Phippen i Simon, 1998).

U tabeli 4 dat je uporedni prikaz sadržaja antocijana u $O$. basilicum „Purple Ruffles“ i drugih biljaka (Simon i sar., 1999). 
Tabela 4. Sadržaj antocijana u biljkama

\begin{tabular}{lccc} 
Biljna vrsta & Deo biljke & $\begin{array}{c}\text { Sadržaj } \\
\text { antocijana } \\
(\mathbf{m g} / \mathbf{1 0 0} \text { g) }\end{array}$ & $\begin{array}{c}\text { Broj } \\
\text { identifikovanih } \\
\text { antocijana }\end{array}$ \\
\hline \hline Grožđe (Vitis labrusca „Concord“) & pokožica & $25,2 \pm 2,9$ & 16 \\
\hline $\begin{array}{l}\text { Purpurni bosiljak (Ocimum basilicum } \\
\text { „Purple Ruffles“) }\end{array}$ & list & $18,8 \pm 0,7$ & 14 \\
\hline Perila (Perilla frutescens „Crispa“) & list & $18,1 \pm 0,6$ & 6 \\
\hline Šljiva (Prunus domestica L. „Stanley“) & pokožica & $15,9 \pm 2,1$ & 2 \\
\hline Purpurna žalfija (Salvia officinalis „Purpurea“) & list & $7,8 \pm 1,0$ & 5 \\
\hline Ljubičasti kupus (Brassica oleracea „Cardinal“) & list & $7,8 \pm 1,4$ & 6 \\
\hline Malina (Rubus idaeus „Heritage“) & plod & $1,0 \pm 0,7$ & 2 \\
\hline
\end{tabular}

\subsubsection{Ostala jedinjenja}

Bosiljak sadrži i vitamine $\mathrm{B}_{1}, \mathrm{~B}_{6}$ i $\mathrm{C}$, karoten i gorke materije (tabela 5). U herbi su prisutni i heterozidi, fenilkarbonske kiseline i njihovi derivati. $U$ većem procentu su zastupljeni i tanini, masne materije, proteini i ugljeni hidrati. On je dobar izvor magnezijuma koji podstiče očuvanje kardiovaskularnog sistema, osnažuje srčani mišić i deluje preventivno protiv infarkta.

Tabela 5. Sadržaj nutritivnih elemenata u 100 g svežeg bosiljka

\begin{tabular}{|c|c|}
\hline Nutritivni elementi & Sadržaj \\
\hline Masti & $0,64 \mathrm{~g}$ \\
\hline Proteini & $3,15 \mathrm{~g}$ \\
\hline Voda & $92,06 \mathrm{~g}$ \\
\hline Vitamin A & $264 \mu \mathrm{g}$ \\
\hline$\beta$-karoten & $3142 \mu \mathrm{g}$ \\
\hline Tiamin $\left(\right.$ Vit. $\left.B_{1}\right)$ & $0,034 \mathrm{mg}$ \\
\hline Riboflavin (Vit. $\mathrm{B}_{2}$ ) & $0,076 \mathrm{mg}$ \\
\hline Niacin (Vit. $\left.B_{3}\right)$ & $0,902 \mathrm{mg}$ \\
\hline Pantotenska kiselina (Vit $\mathrm{B}_{5}$ ) & $0,209 \mathrm{mg}$ \\
\hline Vitamin $\mathrm{B}_{6}$ & $0,155 \mathrm{mg}$ \\
\hline Vitamin $\mathrm{B}_{9}$ & $68 \mu \mathrm{g}$ \\
\hline Holin & $11,4 \mathrm{mg}$ \\
\hline Vitamin C & $18,0 \mathrm{mg}$ \\
\hline Vitamin E & $0,80 \mathrm{mg}$ \\
\hline Vitamin K & $414,8 \mu \mathrm{g}$ \\
\hline $\mathrm{Ca}$ & $177 \mathrm{mg}$ \\
\hline $\mathrm{Fe}$ & $3,17 \mathrm{mg}$ \\
\hline $\mathrm{Mg}$ & $64 \mathrm{mg}$ \\
\hline $\mathrm{P}$ & $56 \mathrm{mg}$ \\
\hline K & $295 \mathrm{mg}$ \\
\hline $\mathrm{Na}$ & $4 \mathrm{mg}$ \\
\hline $\mathrm{Zn}$ & $0,81 \mathrm{mg}$ \\
\hline
\end{tabular}




\subsection{DEJSTVO I UPOTREBA}

Već nekoliko hiljada godina ljudi širom planete koriste lekovitost bosiljka. Ova prijatna i aromatična biljka spada u omiljenu biljnu vrstu kod nas. Najčešće se koristi kao začinska biljka koja jelu daje karakterističan miris i ukus. Odlična je zamena za so, pa način ishrane u kojem se umesto soli koristi začinsko bilje deluje i na snižavanje visokog krvnog pritiska. Osim što poboljšava ukus i obogaćuje miris mnogih jela, bosiljak svojim sastojcima povoljno utiče na zdravlje organizma.

U obliku čajeva najčešće se primenjuje kod lečenja upala (želuca, creva), kod kašlja, početnih stanja tuberkuloze i kod bolesti mokraćnih organa, gde pojačava mokrenje i tako ispoljava svoje uroantiseptično dejstvo. Primena čaja od bosiljka pokazuje i povoljno antitrombocitno dejstvo, pa je upotreba ovog čaja povoljna u prevenciji kardiovaskularnih oboljenja.

Etarsko ulje se koristi u aromaterapiji, jer svojim aromatičnim mirisom povoljno deluje na nervni sistem: smiruje nervnu napetost, migrene, poboljšava pamćenje, otklanja mentalni umor i nesanicu. Osim toga, etarsko ulje (Basilici aetheroleum) ima antiseptično, uroantiseptično, antimikrobno (Nebedum i sar., 2009, Nguefack i sar., 2004), antivirusno (Sanchez i sar., 2010) i antiinflamatorno delovanje. Deluje i kao blagi karminativ, holagog i sekretagog. Etarsko ulje ove biljke se koristi za aromatizaciju farmaceutskih proizvoda, a u parfimerijskoj industriji za izradu parfema i kozmetičkih proizvoda. Odlično je sredstvo protiv akni.

Etarsko ulje pokazuje insekticidno (Keita i sar., 2000, Umerie i sar., 1998) i fungicidno (Rai i sar., 1999) delovanje, a sama biljka, kao i etarsko ulje, poznati su kao dobar repelent od komaraca (Nour i sar., 2009, Erler i sar., 2006).

Etarsko ulje (Kelm i sar., 2000, Pripdeevech i sar., 2010) i ekstrakti bosiljka (ekstrahovani organskim rastvaračima i ugljendioksidom u superkritičnom stanju) pokazuju snažna antioksidativna delovanja (Leal i sar., 2008, 2006, Yun i sar., 2003). Jedan od antioksidanasa iz bosiljka je i $\beta$-karoten, koji se u organizmu pretvara u vitamin A, sprečava oksidaciju holesterola u krvotoku i na taj način štiti srce i krvne sudove.

Takođe, postoje podaci da nekoliko varijeteta bosiljka ima snažno protivupalno dejstvo kod artritisa. Unošenje koncentrovanog ekstrakta dve vrste bosiljka - O. americanum i O. tenuiflorum u velikom procentu smanjuje oticanje zglobova. Novija istraživanja vezana su za hipoglikemijsko i hipolipidemijsko delovanje vodenog rastvora bosiljka vrste $O$. sanctum i O. basilicum (Zeggwagh i sar., 2007, Volpato i sar., 2002). Delovanje se zasniva na 
inhibiciji enzima $\beta$-glukozidaze čime se sprečava razgradnja skroba i saharoze, a samim tim i apsorpcija glukoze, što rezultuje smanjenjem nivoa šećera u krvi (Wongsa i sar., 2012). Ispitivanje etarskog ulja $O$. Basilicum pokazuje da visok sadržaj eugenola inhibira agregaciju pločastih ćelija u krvi (Tagnolini i sar., 2006), što svrstava bosiljak u prirodne antikoagulanse.

Bosiljak je između ostalog dobar izvor vitamina $\mathrm{B}_{6}$ i magnezijuma. Vitamin $\mathrm{B}_{6}$ sprečava nakupljanje potencijalno opasnog homocisteina, koji je proizvod prirodnog ćelijskog metabolizma, može oštetiti ćelije krvnih sudova ukoliko se brzo ne pretvori u neškodljivu supstancu. Magnezijum obezbeđuje zdravlje kardiovaskularnog sistema pomažući opuštanje mišića i krvnih sudova. Na taj način podstiče protok krvi i smanjuje rizik od nepravilnog srčanog ritma.

Seme bosiljka (slika 14) se može koristiti kao izvor polisaharida (Razavi i sar., 2009).

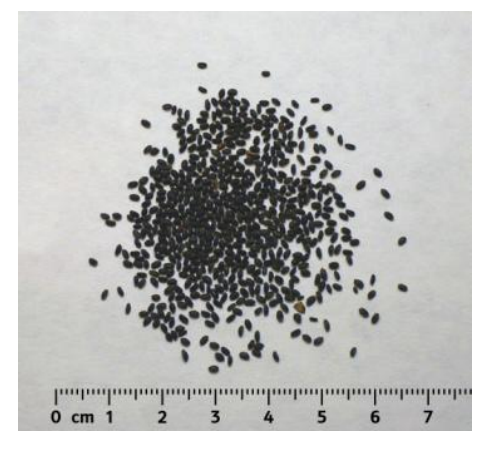

Slika 14. Seme bosiljka

\subsection{EKSTRAKCIJA FLUIDIMA U SUPERKRITIČNOM STANJU}

Superkritična ekstrakcija (eng. Supercritical Fluid Extraction - SFE) se najčešće upotrebljava kao preparativna metoda za dobijanje različitih supstanci iz prirodnih proizvoda (Bevan i sar., 1994). Ova tehnologija je prvo počela da se razvija u Nemačkoj (1979. godine) i doživela industrijsku primenu u prehrambenoj industriji (ekstrakcija kofeina iz zrna kafe i čaja, ekstrakcija hmelja). Najčešće se primenjuje u oblastima dobijanja prirodnih proizvoda (aroma, prirodnih boja, masti i ulja). Dalji razvoj se odnosi na ekstrakciju biljnog materijala za potrebe farmaceutske i kozmetičke industrije.

Superkritična ekstrakcija je postupak ekstrakcije fluidom koji se nalazi u superkritičnom stanju, na temperaturi iznad svoje kritične temperature (Tc) i na pritisku iznad svog kritičnog pritiska $(\mathrm{Pc})$. Superkritični fluid nema definisano stanje, već se njegove fizičko-hemijske karakteristike nalaze između karakteristika tečnosti i gasova (slika 15). Ovaj način ekstrakcije je naročito efikasan za izolaciju supstanci srednjih molekulskih masa i relativno male polarnosti. Rastvorljivost polarnijih supstanci se može poboljšati dodatkom polarnih rastvarača (kosolvenata, modifikatora ili entrejnera) superkritičnom fluidu u malim 
udelima (5 - 20\%). U prehrambenoj industriji etanol i voda su najčešće korišćeni kosolventi za ekstrakciju polarnih komponenti (Skala i sar., 2002).

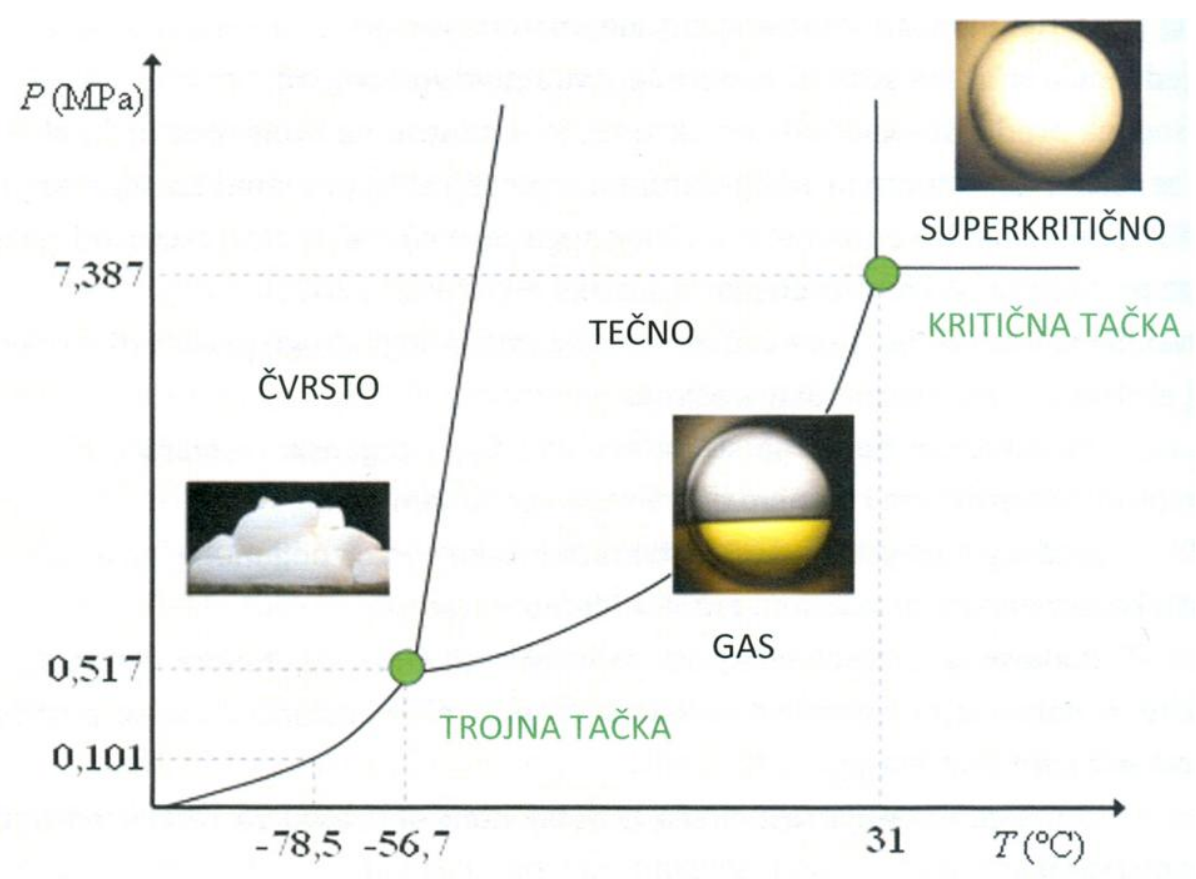

Slika 15. Fazni dijagram (pritisak - temperatura) za ugljendioksid

Izbor odgovarajućeg ekstragensa zavisi od fizičko-hemijskih karakteristika fluida koji se mogu koristiti za ekstrakciju u superkritičnom stanju (tabela 6), a koji ujedno određuje i konstrukcione karakteristike tehnologije, odnosno samog uređaja za ovu vrstu ekstrakcije (Sovová i sar., 2011).

Tabela 6. Kritične tačke fluida koji se koriste za superkritičnu ekstrakciju

\begin{tabular}{lccc}
\multicolumn{1}{c}{ Fluid } & $\begin{array}{c}\text { Kritična temperatura } \\
\left({ }^{\circ} \mathbf{C}\right)\end{array}$ & $\begin{array}{c}\text { Kritični pritisak } \\
(\text { bar })\end{array}$ & $\begin{array}{c}\text { Gustina } \\
\left(\mathbf{k g} / \mathbf{m}^{\mathbf{3}}\right)\end{array}$ \\
\hline etilen & 9,3 & 50,4 & 218 \\
ugljendioksid & 31,3 & 73,8 & 468 \\
etan & 32,3 & 48,8 & 203 \\
azot oksid & 36,7 & 72,7 & 470 \\
propilen & 91,9 & 46,2 & 233 \\
propan & 96,7 & 42,5 & 217 \\
amonijak & 132,5 & 112,8 & 235 \\
dietiletar & 194 & 36,4 & 265 \\
metanol & 239,6 & 80,9 & 272 \\
etanol & 240,9 & 61,4 & 276 \\
voda & 374,2 & 220,5 & 322 \\
\hline
\end{tabular}


Najčešće korišćeni fluid je ugljendioksid zbog svojih povoljnih fizičko-hemijskih karakteristika:

$>$ kritična temperatura $\left(31,1^{\circ} \mathrm{C}\right)$, koja je nešto iznad sobne temperature, se veoma lako postiže, dok je kritični pritisak (73,8 bar) relativno nizak;

$>$ lako je isparljiv na niskim temperaturama, pa se lako izdvaja iz ekstrakta;

$>$ ovim postupkom se dobijaju čisti ekstrakti bez tragova rastvarača;

$>$ velika selektivnost ekstragensa postiže se variranjem parametara procesa (pritisak, temperatura, protok) čime se može postići frakcionisanje;

$>$ netoksičan je i hemijski inertan, bez mirisa;

$>$ lako je dostupan, relativno jeftin.

Prelaz ugljendioksida u superkritično stanje prikazan je na slici 16. Ispod kritičnih parametara, temperature i pritiska, ugljendioksid postoji u dve faze (tečnoj i gasovitoj). Povećanjem temperature vidljivost granice između faza se smanjuje jer gustina tečne i gasovite faze postaje sve sličnija. Kada je postignuta kritična temperatura $\left(31,1^{\circ} \mathrm{C}\right) \mathrm{i}$ kritični pritisak (73,8 bar), razlika između tečne i gasovite faze prestaje biti uočljiva, pa one formiraju novu homogenu fazu - superkritični fluid (Knežević, 2008).

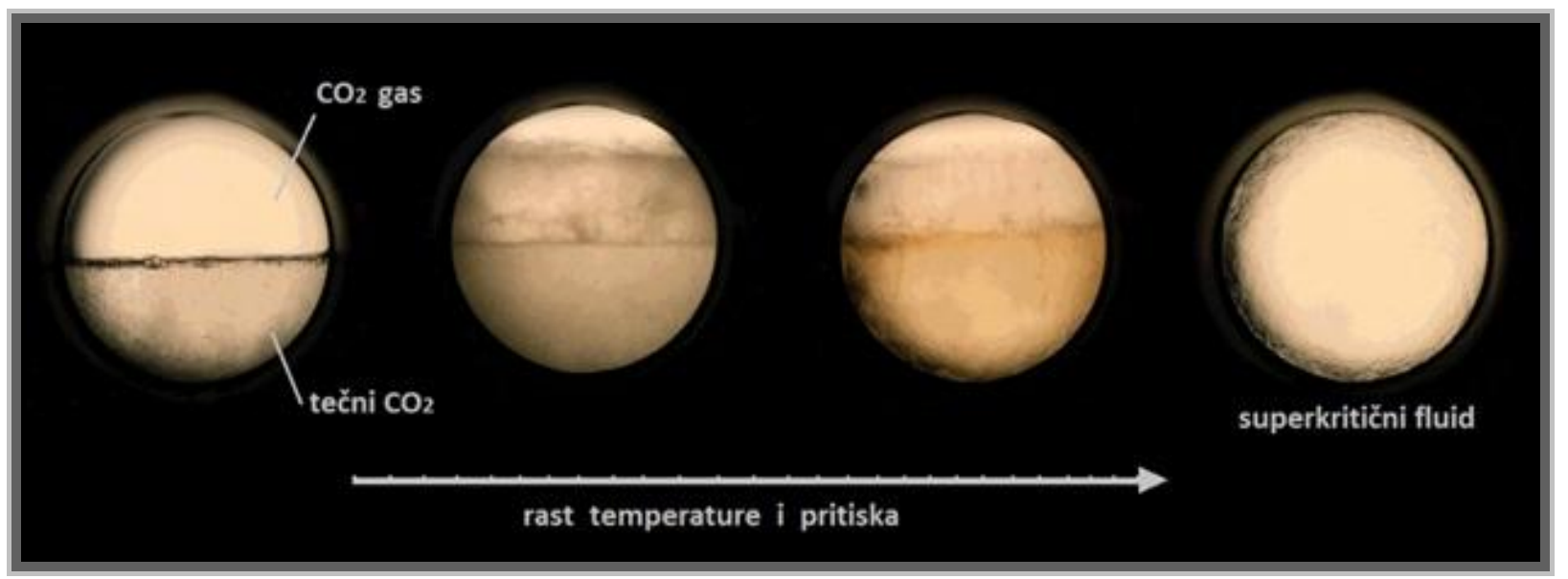

Slika 16. Prelaz $\mathrm{CO}_{2}$ u superkritično stanje

\subsubsection{Karakteristike fluida u superkritičnom stanju}

Fizičke osobine fluida u superkritičnom stanju nalaze se između vrednosti gasovitog i tečnog stanja, što ih čini pogodnim rastvaračima. Fluidi u superkritičnom stanju se odlikuju velikom gustinom, bliskoj gustini tečnosti, zbog čega poseduju i veliku moć rastvaranja (tabela 7). Difuzivnost nadkritičnih fluida je velika i bliska gasovima, dok im je viskozitet mali i blizak viskozitetu gasova, što omogućava lako prodiranje u materijal i rastvaranje. $\mathrm{Na}$ 
slici 17 se uočava da u oblasti neposredno iznad kritičnog pritiska i temperature, relativno male promene pritiska i/ili temperature dovode do značajnih promena gustine ugljendioksida kao ekstragensa. Osnova superkritične ekstrakcije je variranje rastvorljivosti date komponente $\mathrm{u}$ rastvaraču u zavisnosti od pritiska i temperature. Fluidi u superkritičnom stanju imaju znatno veću moć rastvaranja i stepen selektivnosti, a koeficijente difuzije veće čak oko 100 puta od klasičnih tečnih rastvarača koji se koriste u procesu ekstrakcije. Naime, superkritični fluidi imaju sposobnost rastvaranja kao i organski rastvarači, ali sa boljom difuzijom, nižom viskoznosti i manjim površinskim naponom fluida.

Tabela 7. Fizičko-hemijske karakteristike fluida

\begin{tabular}{lccc} 
STANJE FLUIDA & $\begin{array}{c}\text { Gustina } \\
\left(\mathbf{k g} / \mathbf{m}^{3}\right)\end{array}$ & $\begin{array}{c}\text { Koeficijent difuzije } \\
\left(\mathbf{c m}^{2} / \mathbf{s}\right)\end{array}$ & $\begin{array}{c}\text { Viskozitet } \\
(\mathbf{P a ~ s})\end{array}$ \\
Gasovito & 1 & 0,1 & $10^{-5}$ \\
Tečno & $300-900$ & $10^{-3}-10^{-4}$ & $10^{-4}$ \\
Superkritični fluid & $<1000$ & $10^{-5}$ & $10^{-3}$ \\
\hline
\end{tabular}

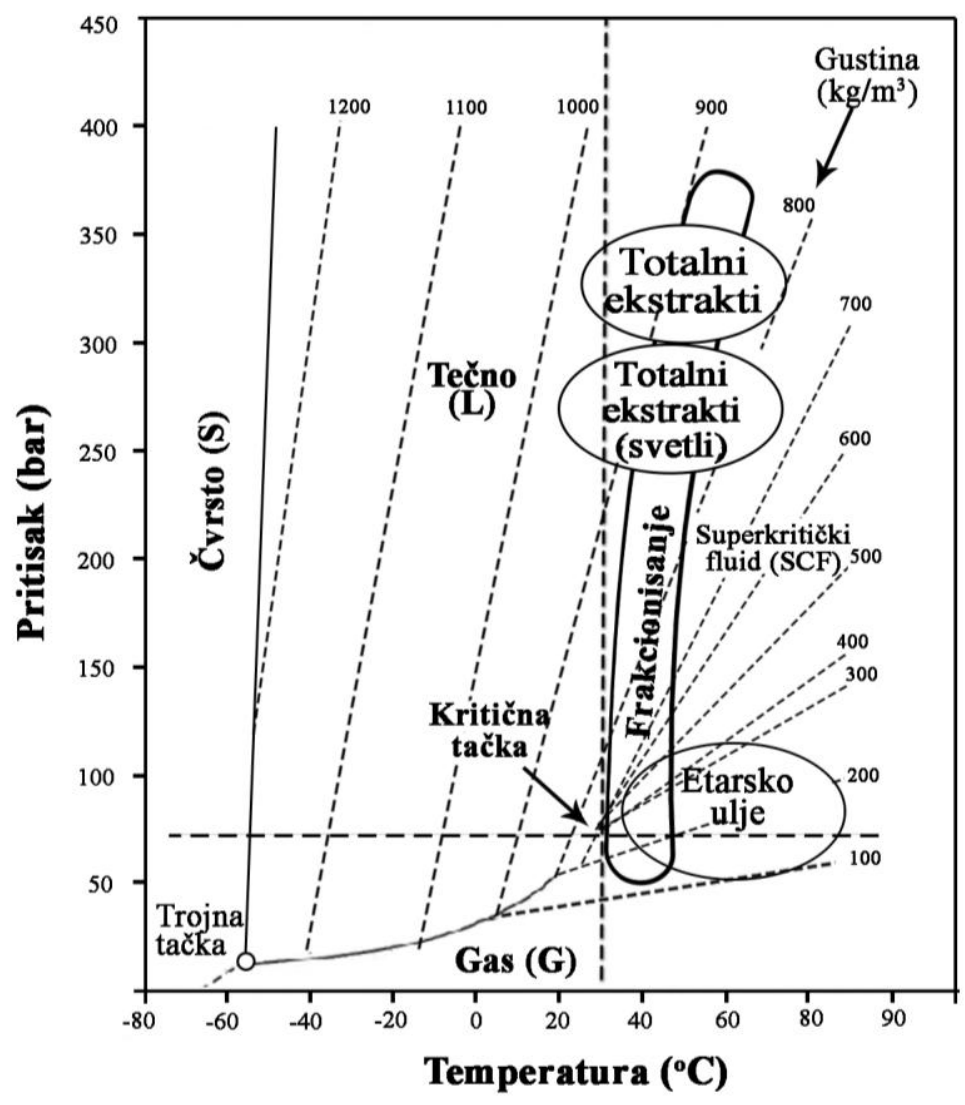

Slika 17. Gustina $\mathrm{CO}_{2}$ u funkciji pritiska i temperature u superkritičnoj oblasti 
Moć rastvaranja $\mathrm{CO}_{2}$ kao ekstrakcionog sredstva zavisi uglavnom od primenjenog pritiska i temperature tokom ekstrakcije (gustine $\mathrm{CO}_{2}$ ). Može se generalno usvojiti za superkritični fluid da:

moć rastvaranja superkritičnog fluida raste sa gustinom na datoj temperaturi,

$>$ moć rastvaranja superkritičnog fluida raste sa temperaturom pri datoj gustini.

Pošto se ekstrakcija gasovima u superkritičnom stanju zasniva na prelasku isparljivih komponenata iz polaznog materijala u nadkritični fluid, izdvajanje željenih komponenata iz superkritičnog fluida postiže se snižavanjem pritiska i/ili temperature radnog fluida.

Uopšteno, proces ekstrakcije superkritičnim fluidima odvija se u pet uzastopnih faza (Wakao i Kaguei, 1982; Nikolovska, 2009):

1) difuzija superkritičnog fluida do površine čestice kroz film fluida koji je okružuje;

2) prodiranje i difuzija superkritičnog fluida kroz spoljašnji sloj sfernog omotača krutog, inertnog, materijala;

3) kontakt superkritičnog fluida sa rastvorljivom supstancom na površini neizregovanog jezgra i ekstrakcija rastvorljive komponente;

4) difuzija rastvorljive supstance u superkritičnom fluidu kroz sloj spoljašnjeg sfernog omotača na spoljašnju površinu čestice;

5) difuzija rasvorljive komponente u superkritičnom fluidu kroz film superkritičnog fluida koji okružuje česticu.
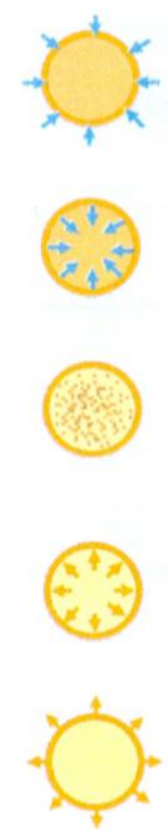

U većini savremenih komercijalinih postupaka ekstrakcije prirodnih proizvoda superkritičnim fluidima, ekstrakt se dobija iz nasutog sloja čvrstog materijala u ekstraktoru. Raznovrsni i mnogobrojni faktori utiču na proces ekstrakcije, a najznačajniji među njima su:

- pritisak, temperatura i protok rastvarača (solventa),

- gustina, viskoznost, difuzivnost rastvarača i materije koja se ekstrahuje,

- interakcije između molekula rastvarača, rastvorka i nerastvornog dela čvrstog materijala (matriksa) u kome se nalazi rastvorak, koji utiču na faznu ravnotežu i koeficijente difuzije,

- oblik, veličina i raspodela veličina čestica materijala u sloju, poroznost čestica i poroznost sloja. 
Upotreba fluida u superkritičnom stanju za ekstrakciju nekog rastvorka uslovljena je rastvorljivošću i faznom ravnotežom komponenata prisutnih u polaznom materijalu i komprimovanom gasu. Rastvorak mora biti rastvorljiv u superkritičnom fluidu na umerenim pritiscima i temperaturama. Promenom pritiska i temperature mogu se $u$ širokom opsegu vrednosti menjati rastvorljivost i fazna ravnoteža.

\subsubsection{Prednosti i nedostaci superkritične ekstrakcije (SFE)}

Superkritična ekstrakcija (SFE) ima niz prednosti u odnosu na klasičnu ekstrakciju (Lang i Wai, 2001, Luque de Castro i Jimenéz-Carmona, 2000, King, 2002, Wang i Weller, 2006, Norhuda i Jusoff, 2009, Sahena i sar., 2009):

> kontrola moći rastvaranja superkritičnog fluida postiže se promenom pritiska i/ili temperature;

> razdvajanje ekstrakta od superkritičnog fluida je lako i brzo zbog mogućnosti regulisanja isparljivosti komponenata promenom pritiska i temperature;

> znatno bolje razdvajanje faza, koje nije moguće postići klasičnom ekstrakcijom;

> dodavanjem kosolvenata (metanola, etanola, vode i dr.) moguće je poboljšati rastvaranje i ekstrakciju polarnih komponenata čime se postiže veća selektivnost prilikom ekstrakcije;

$>$ ekstrakcija termolabilnih komponenata sa minimalnim degradacijama, zbog rada na niskim temperaturama;

> nema zaostajanja rastvarača u dobijenom ekstraktu za razliku od upotrebe organskih rastvarača;

> $\mathrm{CO}_{2}$ je kao ekstragens ekološki prihvatljiv (GRAS - eng. Generally recognised as safe), fiziološki bezopasan, netoksičan, nezapaljiv i ne izaziva probleme u procesnom inženjerstvu;

> Za ekstrakciju superkritičnim fluidom mogu se primeniti postrojenja različitih kapaciteta, od analitičkih (manje od grama do nekoliko miligrama uzorka), preparativnih (nekoliko stotina grama uzorka), poluindustrijskih (kilogram uzorka) do velikih industrijskih postrojenja (tone sirovine). 
Nedostaci superkritične ekstrakcije u poređenju sa drugim postupcima ekstrakcije su:

$>$ rad na relativno visokim pritiscima;

> veliki utrošak energije za komprimovanje gasova;

> znatni energetski troškovi za regeneraciju rastvarača;

$>$ veliki investicioni troškovi za procesnu opremu i

> kompleksnost samog procesa ekstrakcije.

Fluidima u superkritičnom stanju ekstrahovane su različite biljne sirovine. Ovim postupkom mogu se dobiti etarska i masna ulja, aromatične komponente, farmakološki aktivne supstance i komponente sa antioksidativnim i antibakterijskim dejstvom. U tabeli 8 je dat pregled primene superkritične ekstrakcije za izolovanje različitih komponenata iz prirodnih sirovina u poslednjih desetak godina.

Tabela 8. Primeri primene superkritične ekstrakcije u poslednjoj deceniji

\begin{tabular}{lll} 
Biljni materijal & Ekstrakt & Reference \\
\hline Seme celera & etarsko ulje & Papamichail i sar., 2000 \\
Ocimum basilicum & etarsko ulje & Leal i sar., 2008 \\
Seme grožđa & masno ulje & Murga i sar., 2000 \\
Rosmarinus officinalis & etarsko ulje & Ramirez i sar., 2005, Celiktas i sar., 2007, \\
Salvia officinalis & etarsko ulje & Babović i sar., 2009; \\
Thymus vulgaris & etarsko ulje & Babović i sar., 2009 \\
Hyssop officinalis & etarsko ulje & Babović i sar., 2009 \\
Mentha spicata & etarsko ulje & Bimakr i sar., 2009 \\
Pšenična klica & masno ulje & Gelmez i sar., 2009 \\
Pistachia vera & masno ulje & Goli i sar., 2005 \\
Origanum vulgare & etarsko ulje & Cavero i sar., 2006 \\
Zrno soje & masno ulje & Jokić i sar., 2011 \\
Seme dinje & masno ulje & Nyam i sar., 2010 \\
Seme lana & masno ulje & Nikolovska i sar., 2008 \\
Seme paradajza & masno ulje & Eller i sar., 2010 \\
Zeleni čaj & ekstrakt & Chang i sar., 2010 \\
Pimpinella anisum & etarsko ulje & Rodrigues i sar., 2003 \\
Crvena paprika & oleorezin & Duarte i sar., 2004 \\
Juniperus communis & ulje & Barjaktarović i sar., 2005 \\
\hline
\end{tabular}




\subsection{MATEMATIČKO MODELOVANJE SUPERKRITIČNE EKSTRAKCIJE}

Matematičko modelovanje u procesima superkritične ekstrakcije ima važnu ulogu s obzirom na to da omogućava relativno brzo procenjivanje uticaja različitih procesnih vrednosti na izlazne parametre procesa uz smanjenje broja potrebnih eksperimentalnih podataka (Diaz i Brignole, 2009). Ukoliko se želi optimizovati proces, odnosno obezbediti najveći mogući prinos za najkraće vreme uz najmanji utrošak rastvarača i energije, ili je potrebno povaćati kapacitet i dimenzije uređaja (scale-up), tada je potrebno matematički opisati proces prenosa mase odgovarajućim modelom. Matematički modeli se primenjuju u cilju kvantitativnog opisa kinetike različitih ekstrakcionih procesa.

Ni jedan od matematičkih modela koji postoji u literaturi u potpunosti ne zadovoljava krajnje zahtevne potrebe jednog univerzalnog matematičkog modela kojim bi se opisao proces superkritiče ekstrakcije. Razlog za to je izuzetno velika šarolikost ekstrakcionih procesa koji obuhvataju mnogo različitih prirodnih sirovina i hemijskih jedninjenja koja se tom prilikom izdvajaju. Zato su raspoloživi matematički modeli najčešće primenjivi samo za određene sisteme, ili imaju neko drugo ograničenje u primeni (Nikolovski, 2009, Hortaçsu, 2000).

U većini slučajeva, pri ekstrakciji prirodnih materijala, gotovo se nikad ne ekstrahuje samo jedno jedinjenje u toku procesa, već se dobijaju višekomponentni ekstrakti. Karakteristike komponenata koje se ekstrahuju, kao i sličnosti i razlike prisutnih komponenata, imaju veliki uticaj na izbor matematičkog modela kojim je moguće opisati proces. Mogu se uočiti dve osnovne grupe materijala koji se ekstrahuju: seme biljaka uljarica iz kojih se ekstrahuju masna ulja, i biljke ili delovi biljaka iz kojih se ekstrahuju etarska ulja. Pri ekstrakciji biljnih ulja superkritičnim ugljendioksidom prinosi su veliki, i proces se može matematički opisati kao jednostepena ekstrakcija jedne pseudo-komponente. Pri ekstrakcija etarskih ulja prinosi su mali, a sam proces ekstrakcije je složen, jer je proizvod koji se dobija sastavljen od velikog broja jedinjenja tipa terpena ili njihovih derivata (Nikolovski, 2009). Zbog toga je većina matematičkih modela primenjiva ili na ekstrakciju eterskih ulja ili na ekstrakciju masnih ulja. Noviji pregled matematičkih modela koji se koriste za opisivanje superkritične ekstrakcije biljnih ulja dali su del Valle i de la Fuente (2006). Postoji nekoliko modela koji se mogu primeniti za ekstrakciju obe vrste sirovina (Reverchon i sar., 1994, 1999, 2001, Savová, 1994, 2005, del Valle i sar., 2000). 
Matematički modeli koji se koriste za opisivanje procesa ekstrakcije superkritičnim fluidima mogu se podeliti u sledeće grupe:

1. empirijski modeli (Kandiah i Spiro, 1990, Subra i sar., 1998, Papamichail i sar., 2000),

2. modeli bazirani na analogiji prenosa mase i toplote (Reverchon i sar., 1993, Esquivel i sar., 1999),

3. modeli zasnovani na diferencijalnom bilansu mase (Sovová, 1994, Perrut i sar., 1997, Marrone i sar.,1998, Reverchon i Marrone, 2001).

Fenomenološki gledano, sveobuhvatnija je klasifikacija koju je dao Hortaçsu (2000) na:

- modele u kojima je ekstrakcija objašnjena kao hemijska reakcija i

- modele u kojima je ekstrakcija posmatrana kao fizički fenomen.

Iako je po definiciji ekstrakcija fizički fenomen, modeli bazirani na hemijskoj reakciji mogu se opravdati činjenicom da je dostupnost nekih materija koje treba ekstrahovati $u$ potpunoj zavisnosti od hemijskih reakcija kojima se one dobijaju u prirodnom matriksu. Zbog toga su ovi modeli korišćeni uglavnom za opisivanje ekstrakcije lignina iz biomase, odnosno drveta, a slični modeli su korišćeni i za superkritičnu ekstrakciju etarskih ulja.

Kandiah i Spiro (1990) su primenili reakcioni model za superkritičnu ekstrakciju đumbira i konstatovali da postoji velika zavisnost brzine hemijske reakcije od veličine čestica đumbira. Prinos ekstrakta se može izračunati prema sledećoj jednačini:

$\mathrm{Y}_{\mathrm{E}}=x_{0}\left\{\left[1-\left[f r_{1} \exp \left(-k_{1} t\right)\right]+f r_{2} \exp \left(-k_{2} t\right)\right]\right\}$

gde je:

$\begin{array}{ll}\mathrm{Y}_{\mathrm{E}} & \text { prinos ekstrakta }(\%), \\ x_{0} & \text { početni sadržaj rastvorljive supstance }(\mathrm{kg} / \mathrm{kg}), \\ f r_{1}, f r_{2} & \text { frakcije ekstrahovane supstance, } \\ k_{1}, k_{2} & \text { konstanta brzine u dva perioda difuzije }(1 / \mathrm{s}), \\ t & \text { vreme ekstrakcije (s). }\end{array}$

Takođe, model baziran na hemijskoj reakciji ima smisla primenjivati samo $\mathrm{u}$ slučajevima kada je hemijska reakcija u toku ekstrakcionog procesa najsporija i samim time kontrolišući faktor, dok su brzina desorpcije, rastvaranje i difuzija ekstrahovanih komponenata prevelike da bi usporavale proces. Kod ekstrakcije etarskih i biljnih ulja to nije slučaj, jer se ne sintetišu u prirodnom matriksu u toku ekstrakcije, već kao takve postoje u njemu i nisu hemijski vezane za njega. 
Model baziran na fizičkim fenomenima stavlja akcenat na fizičke fenomene tokom ekstrakcije. Većina matematičkih modela u literaturi posmatra ekstrakciju fluidima u superkritičnom stanju kao čisto fizički fenomen i bazira se na diferencijalnom bilansu mase.

Sve ostale podele modela i razlike između njih proizilaze iz zanemarivanja pojedinih od pet stadijuma ili njihovog pojednostavljenja uvođenjem određenih pretpostavki.

Većina matematičkih modela koji opisuju kinetiku ekstrakcije baziraju se na bilansu mase fenomenima prenosa toplote i mase u procesu ekstrakcije. Sloj punjenja materijala $u$ ekstraktoru može se podeliti u dve faze: a) čvrsta faza, koja se sastoji od sirovine koja se ekstrahuje i b) fluidne faze, koja se sastoji od superkritičnog ekstragensa sa rastvorljivom supstancom u njemu. Pretpostavlja se da je ekstraktor cilindričnog oblika i da superkritični fluid prolazi aksijalno kroz sloj materijala u ekstraktoru, pri čemu odnosi rastvorljive supstance iz čvrste faze. Obe faze, i čvrsta i tečna, zauzimaju zapreminu ekstraktora. Prema ovim pretpostavkama, bilans mase u obe faze može se prikazati sledećim izrazima:

$$
\begin{aligned}
& \frac{\partial \mathrm{Y}}{\partial t}+u_{i} \frac{\partial \mathrm{Y}}{\partial h}=\frac{\partial}{\partial h}\left(D_{a y} \frac{\partial \mathrm{Y}}{\partial h}\right)+\frac{J(x, y)}{\varepsilon} \\
& \frac{\partial X}{\partial t}=\frac{\partial}{\partial h} u_{i}\left(D_{a x} \frac{\partial X}{\partial h}\right)-\frac{J(x, y)}{(1-\varepsilon)} \frac{\rho_{f}}{\rho_{s}}
\end{aligned}
$$

gde su:

$\begin{array}{ll}x \text { i } y & \text { bezdimenzionalna koncentracija čvrste i fluidne faze, } \\ u_{i} & \text { protok }(\mathrm{m} / \mathrm{s}), \\ h & \text { aksijalna koordinata sloja punjenja u ekstraktoru }(\mathrm{m}), \\ D_{a x} & \text { koeficijent difuzije u čvrstoj fazi }\left(\mathrm{m}^{2} / \mathrm{s}\right), \\ D_{a y} & \text { koeficijent aksijalne disperzije }\left(\mathrm{m}^{2} / \mathrm{s}\right), \\ \rho_{f}, \rho_{s} & \text { gustina superkritičnog fluida i gustina čestica materijala }\left(\mathrm{kg} / \mathrm{m}^{3}\right), \\ J(x, y) & \text { tok prenosa mase na granici faza }(1 / \mathrm{s}) .\end{array}$

$\mathrm{Na}$ osnovu jednačina (2) i (3) fenomeni prenosa mase koji postoje tokom procesa superkritične ekstrakcije su sledeći: akumulacija u obe faze, konvekcija i disperzija u tečnoj fazi, difuzija u čvrstoj fazi i površinski prenos mase. Razlika između modela datih u literaturi je u njihovom tumačenju pojedinih fenomena i zanemarivanju nekih od njih (Oliveira i sar., 2011). 


\subsubsection{Modeli zasnovani na diferencijalnom masenom bilansu (opšti model)}

Osnovni - opšti model baziran na diferencijalnim bilansima mase za rastvorak u masi superkritičnog fluida, u fluidu, u porama čvrste faze i u čvrstoj fazi predložili su Akgerman i Madras (1994) (tabela 9).

Tabela 9. Opšti model za superkritičnu ekstrakciju čvrstog materijala u nasutom sloju

\section{Diferencijalni bilans mase rastvorka u masi fluida}

$$
\frac{\partial c_{f}}{\partial t}+u \frac{\partial c_{f}}{\partial z}-D_{L} \frac{\partial^{2} c_{f}}{\partial z^{2}}=\frac{3}{R} \frac{1-\varepsilon}{\varepsilon} J
$$

Početni uslov: $\quad c_{f}=0$

(za $t=0$, za svako $z)$

Granični uslovi: $\quad D_{L} \frac{\partial c_{f}}{\partial z}=u c_{f}$

$($ za $z=0$, za svako $t)$

$$
\frac{\partial c_{f}}{\partial z}=0
$$

$($ za $z=\mathrm{L}$, za svako $t)$

Diferencijalni bilans mase rastvorka u fluidu unutar pora čvrstog materijala

$$
\frac{\partial c_{p}}{\partial t}+\frac{1}{\varepsilon_{p}} \frac{\partial c_{s}}{\partial t}=-\frac{D_{e}}{r^{2}} \frac{\partial}{\partial r}\left(r^{2} \frac{\partial c_{p}}{\partial r}\right)
$$

Početni uslov: $\quad c_{p}=c_{p 0}$

(za $t=0$, za svako $r$ i $z$ )

$$
\mathrm{c}_{\mathrm{s}}=\mathrm{c}_{\mathrm{s} 0}
$$

(za $t=0$, za svako $r \mathrm{i} z$ )

Granični uslovi:

$$
\begin{array}{ll}
\frac{\partial c_{p}}{\partial r}=0 & (\text { za } r=0, \text { za svako } z \text { i } t) \\
\frac{\partial c_{s}}{\partial r}=0 & (\text { za } r=0, \text { za svako } z \text { i } t) \\
\varepsilon_{p} D_{e} \frac{\partial c_{p}}{\partial r}=-\mathrm{J} & (\text { za } r=R, \text { za svako } z \text { i } t)
\end{array}
$$

\section{Definicije:}

Brzina prenosa $\quad \mathrm{J}=\mathrm{k}_{\mathrm{f}}\left(\mathrm{c}_{\mathrm{p}} \mid \mathrm{R}-\mathrm{c}_{\mathrm{f}}\right)$

mase:

Fazna ravnoteža: $\quad c_{s}=f\left(c_{p}\right)$ 
Na opšti model odnose se sledeće pretpostavke:

1. čestice materijala iz kojeg se ekstrahuje rastvorak su porozne sfere (poluprečnika R i poroznosti $\varepsilon_{\mathrm{p}}$ ) i formiraju nasuti sloj;

2. fluid u superkritičnom stanju struji između čestica materijala u sloju konstantnom brzinom $\mathrm{u}=\mathrm{U} / \varepsilon$, gde je $\varepsilon$ poroznost sloja, koja je konstantna;

3. fizička svojstva fluida u superkritičnom stanju i materijala ostaju konstantna;

4. pad pritiska i temperaturni gradijenti u sloju mogu da se zanemare;

5. rastvorak je aksijano dispergovan u superkritičnom fluidu.

U skladu sa poslednjom pretpostavkom, rastvorak iz materijala rastvoren u superkritičnom fluidu difunduje duž nasutog sloja materijala u ekstraktoru kao posledica postojanja aksijalnog koncentracionog gradijenta. U čvrstom matriksu rastvorak se može naći apsorbovan na čvrstu materiju (koncentracija $\mathrm{c}_{\mathrm{s}}$ ) i rastvoren $\mathrm{u}$ fluidnoj fazi unutar pora materijala (koncentracija $c_{p}$ ).

Svi modeli bazirani na diferencijalnom bilansu mase proizilaze iz opšteg modela i gotovo kod svih jednačine za prenos mase u fazi superkritičnog fluida su u osnovi iste.

\subsubsection{Jednostavan model baziran na kinetici prvog reda}

Brunner (1984) je predložio jednostavan model koji se bazira na reakcijama kinetike prvog reda, gde je prinos ekstrakta u funkciji vremena opisan sledećom jednačinom:

$$
\mathrm{Y}_{\mathrm{E}}=x_{0}\left(1-e^{-k t}\right)
$$

gde je:

$$
\begin{array}{ll}
\mathrm{Y}_{\mathrm{E}} & \text { prinos ekstrakta }(\%), \\
x_{0} & \text { početni sadržaj rastvorljive supstance }(\mathrm{kg} / \mathrm{kg}), \\
k & \text { koeficijent brzine reakcije }(1 / \mathrm{s}), \\
t & \text { vreme ekstrakcije (s). }
\end{array}
$$

Ovo je najjednostavniji model ekstrakcije koji pretpostavlja da se proces ekstrakcije odvija u jednom stepenu gde je difuzija kontrolisana samo pomoću unutrašnjeg prenosa mase. 


\subsubsection{Model neizreagovanog jezgra (MNJ) u poroznoj sferi}

Jedan od načina opisivanja mehanizma prenosa mase je pomoću modela neizreagovanog jezgra ili SC modela (eng. Shrinking Core model) (slika 18). Model su prvi put u oblast ekstrakcije superkritičnim fluidima primenili King i Catchpole (1993) za matematičko opisivanje ekstrakcije ulja kikirikija.

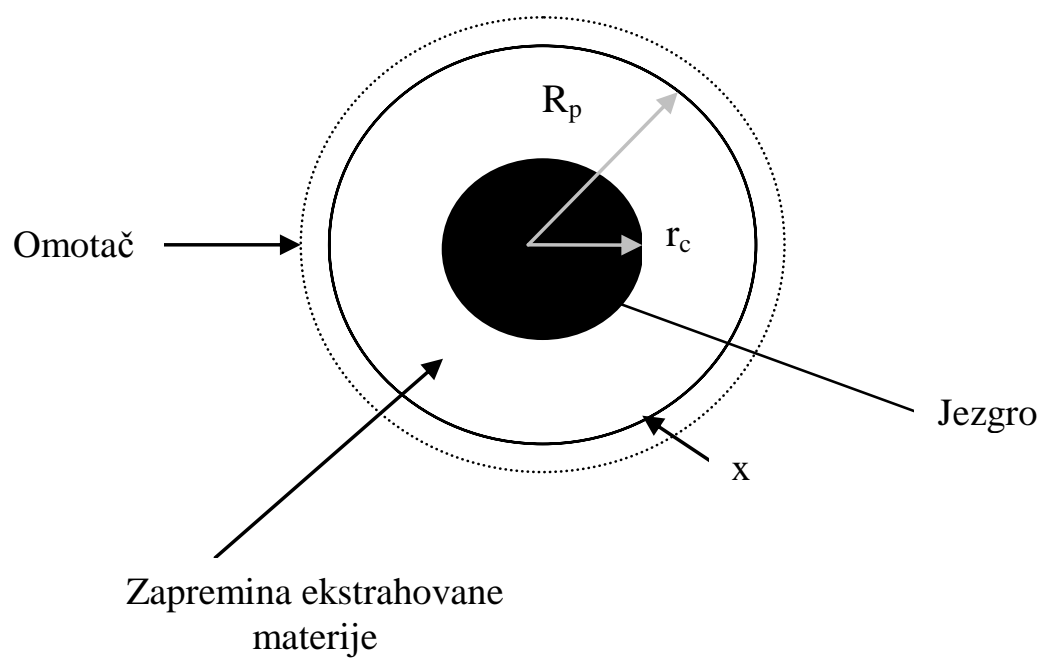

Slika 18. Šema čestice prema modelu neizreagovanog jezgra

Ovaj model pretpostavlja da je na početku ekstrakcije rastvorak ravnomerno raspoređen u porama čvrstog materijala i da ga u poroznoj strukturi drže mehaničke ili kapilarne sile. Ekstrakcija rastvorka se prvo odigrava na spoljašnjoj površini čestice, a zatim se pomera ka unutrašnjosti čvrste čestice. U svakom trenutku od početka ekstrakcije postoji jasno definisana granica između unutrašnjeg dela čestice (neizekstrahovanog jezgra) i spoljašnjeg sfernog omotača od krutog inertnog materijala.

Da bi se dobilo aproksimativno matematičko rešenje ovog problema sa promenljivim graničnim uslovima, mora se pretpostaviti da se difuzija rastvorka u spoljašnjem sfernom omotaču odvija u pseudo-stacionarnim uslovima. Bilans mase rastvorka u fluidu unutar pora čvrstog materijala dat je sledećom diferencijalnom jednačinom:

$\frac{D_{e}}{r^{2}} \frac{\partial}{\partial r}\left(r^{2} \frac{\partial x}{\partial r}\right)=0$ 
gde su:

$$
\begin{array}{ll}
r_{c} & \text { poluprečnik jezgra }(\mathrm{m}), \\
R_{p} & \text { poluprečnik čestice }(\mathrm{m}) .
\end{array}
$$

U slučaju sfernih čestica može se primeniti sledeća korelacija:

$$
\frac{x}{x_{0}}=\left(\frac{r_{c}}{R_{p}}\right)^{3}
$$

Na osnovu izraza (18) može se izračunati prinos ekstrakta prema sledećoj jednačini:

$$
\mathrm{Y}_{\mathrm{E}}=x_{0}\left[1-\left(\frac{r_{c}}{R_{p}}\right)^{3}\right]
$$

Analiza ovog modela pokazuje da se takav model ili modeli koji bi proizašli iz njegovog pojednostavljenja mogu uspešnije primeniti na ekstrakciju semena uljarica (triglicerida), nego na ekstrakciju etarskih ulja koja sadrže veliki broj supstanci različitih karakteristika (del Valle i de la Fuente, 2006). Ovakvo mišljenje je bazirano na činjenici da je spoljašnji sferni omotač od čvrstog inertnog materijala oslobođen prisustva bilo kakvog rastvorka, a u nekim slučajevima pojedine supstance, na svom putu prema površini čestice, mogu se apsorbovati na zidove pora. Ukoliko se to desi, model podrazumeva da mehanizmi kao što su adsorpcija i desorpcija ne upravljaju brzinom procesa. Takođe, polazna pretpostavka modela je da su čestice oblika idealne sfere, što u praksi nikad nije slučaj. Ukoliko fluid protiče klipnim tokom, u modelu figurišu dva parametra, koeficijent prelaza mase sa čvrste faze u fluid i difuzivnost unutar čestice. Treći parametar se pojavljuje kada se razmatra dispergovani klipni tok, odnosno ako postoji aksijalna disperzija (Goto i sar., 1996). 


\subsubsection{Modeli bazirani na mehanizmu desorpcije-rastvaranja-difuzije (DRD) u poroznoj sferi}

U modelima baziranim na mehanizmu desorpcije-rastvaranja-difuzije u poroznoj sferi, u engleskoj literaturi poznatim kao DDD (eng. desorption-dissolutiona-diffusion) modeli, podrazumeva se da je rastvorak prisutan i raspoređen po čitavoj zapremini čestice u toku svih faza ekstrakcionog procesa, bilo adsorbovan na zidovima pora ili kao slobodna tečnost u porama. U toku procesa ekstrakcije neprekidno se odvija desorpcija rastvorka, njegovo rastvaranje u rastvaraču i difuzija kroz česticu, sve do njenog napuštanja. Ekstrahovani materijal koji napušta česticu biva prenesen u glavni tok superkritičnog fluida kroz nasuti sloj. DRD model je često primenjivan za superkritičnu ekstrakciju etarskih ulja iz biljaka (Goto i sar., 1993).

\section{Model desorpcije}

Tan i Liou (1989) su predložili model desorpcije (jednačina (20)) koji sadrži konstantu desorpcije i predstavlja površinski tok prenosa mase koristeći model kinetike prvog reda. Jedini prilagodljivi parametar u ovom modelu je koeficijent desorpcije, koji zavisi od temperature. Autori su zanemarili aksijalnu disperziju i unutrašnju difuziju čestica.

$$
\mathrm{Y}_{\mathrm{E}}=x_{0} \frac{m_{f} \rho_{s}}{m_{s} \rho_{f}} \frac{1-\varepsilon}{\varepsilon} \frac{1}{k_{d}}\left(1-\exp \left(k_{d} \frac{\varepsilon \cdot h_{E}}{u_{s}}\right)\right)\left(\exp \left(-k_{d} t\right)-1\right)
$$

gde je:

$\begin{array}{ll}h_{E} & \text { visina ekstraktora }(\mathrm{m}), \\ u_{s} & \text { brzina strujanja fluida }(\mathrm{m} / \mathrm{s}), \\ m_{f} & \text { maseni protok } \mathrm{CO}_{2}(\mathrm{~kg} / \mathrm{s}), \\ m_{s} & \text { masa materijala u ekstraktoru }(\mathrm{kg}), \\ \rho_{f} & \text { gustina superkritičnog fluida }\left(\mathrm{kg} / \mathrm{m}^{3}\right), \\ \rho_{s} & \text { gustina čestice }\left(\mathrm{kg} / \mathrm{m}^{3}\right), \\ k_{d} & \text { konstanta desorpcije }(-), \\ t & \text { vreme ekstrakcije }(\mathrm{s}) .\end{array}$




\section{Model difuzije}

U nekim slučajevima čvrsta faza se posmatra kao jedinstvena faza, odnosno homogeni matriks, a difuzija se smatra jedinim mehanizmom prenosa mase. U tim slučajevima nema razlike između koncentracije rastvorka u čvrstom matriksu i u njegovim porama, i sve jednačine diferencijalnog prenosa mase u čvrstoj fazi su samo funkcija koncentracije rastvorka u čvrstoj fazi ( $\mathrm{c}_{\mathrm{s}}$ ) (del Valle i de la Fuente, 2006).

$$
\frac{\partial c_{s}}{\partial t}=\frac{D_{e}}{r^{2}} \frac{\partial}{\partial r}\left(r^{2} \frac{\partial c_{s}}{\partial r}\right)
$$

gde je:

$D_{e} \quad$ efektivni koeficijent difuzije rastvorka u čvrstom materijalu $\left(\mathrm{m}^{2} / \mathrm{s}\right)$, $r \quad$ radijalno rastojanje unutar čestice $(\mathrm{m})$.

\subsubsection{Pojednostavljenja modela}

Da bi se izbegli glomazni i komplikovani matematički proračuni, sistemi parcijalnih diferencijalnih jednačina koji proizilaze iz jednačine diferencijanog masenog bilansa za čvrstu fazu i fazu fluida, uprošćavaju se u cilju dobijanja analitičkog rešenja. To se postiže uvođenjem pojednostavljenja i pretpostavki. Na taj način se olakšava procena vrednosti parametara modela na osnovu eksperimentalnih rezultata i omogućava analiza osetljivosti proračuna.

\subsubsection{Modeli koji isključuju aksijalnu disperziju}

Papamichail i saradnici (2000) su dali pojednostavljenje modela bilansa mase na osnovu sledećih pretpostavki:

- ekstrakt se posmatra kao samo jedna komponenta;

- aksijalna disperzija se može zanemariti;

- temperatura, pritisak, gustina i protok rastvarača su konstantni u svakoj tački sloja;

- rastvarač ne sadrži rastvorljivu supstancu na ulazu u ekstraktor;

- sloj materijala u ekstraktoru je homogen. 
Prema navedenim pretpostavkama, može se dobiti sledeće:

$$
\begin{aligned}
& \mathrm{J}=\rho_{f} \varepsilon\left(\frac{\partial y}{\partial t}+u_{i} \frac{\partial y}{\partial h}\right) \\
& \mathrm{J}=-\rho_{s}(1-\varepsilon) \frac{\partial x}{\partial t}
\end{aligned}
$$

gde je $\mathrm{J}$ brzina izmene rastvorljive supstance između faza.

Uz pretpostavku da nema akumulacije rastvorljive supstance u tečnoj fazi $\frac{\partial y}{\partial t}=0 \mathrm{i}$ da je proces ekstrakcije ravnomeran u svakoj tački sloja materijala $\frac{\partial y}{\partial h}=$ konst., Papamichail i saradnici (2000) su napravili dva pojednostavljenja modela.

\subsubsection{Model u kojima je pogonska sila linearna}

U slučaju kada se može usvojiti pretpostavka da je pogonska sila unutrašnje difuzije linearna, mogu se kombinovati procesi prenosa mase u čvrstoj fazi i u okolnom fluidu. Peker i saradnici (1992) pokazali su da je linearnu pogonsku silu (eng. Linear Driving Force - LDF) moguće primeniti u slučaju kada je koncentracioni profil rastvorljive supstance u čvrstoj fazi paraboličan. Linearna pogonska sila se definiše kao funkcija srednje koncentracije rastvorka unutar čestica čvrste faze $\left(\bar{c}_{s}\right)$. Navedeni autori su proučavali ekstrakciju kofeina iz zrna kafe pomoću superkritičnog ugljendioksida.

Goto i saradnici (1990) su proučavali superkritičnu ekstrakciju etarskog ulja Mentha piperita pri čemu su izveli sledeću model jednačinu:

$\varepsilon \frac{d y}{d t}+\frac{y}{t}=-k_{p} a_{t}(1-\varepsilon)(y-x)$

gde je:

vreme zadržavanja rastvarača u ekstraktoru (s).

Koncentracija čestica je prikazana pomoću sledeće jednačine:

$\varepsilon_{p} \frac{d x}{d t}=-k_{p} a_{t}(y-x)-\left(1-\varepsilon_{p}\right) \frac{d x_{f}}{d t}$

gde je:

$$
\begin{array}{ll}
x_{f}=\mathrm{K}_{a d} x & \text { koncentracija rastvorljive supstance na površini čvrstih čestica }(\mathrm{kg} / \mathrm{kg}) \\
\mathrm{K}_{a d} & \text { adsorpcijska konstanta ravnoteže (-). }
\end{array}
$$


Prinos tokom ekstrakcije izračunava se prema jednačini:

$\mathrm{Y}_{\mathrm{E}}=x_{0} \frac{A_{13}}{(1-\varepsilon)}\left(\frac{\exp \left(g_{1} \frac{t}{\bar{t}}\right)-1}{g_{1}}-\frac{\exp \left(g_{2} \frac{t}{\bar{t}}\right)-1}{g_{2}}\right)$

gde su:

$$
\begin{aligned}
& g_{1,2}=\frac{-b_{1} \pm \sqrt{b_{1}^{2}-4 c_{1}}}{2} \\
& b_{1}=\frac{k_{p} a_{t} \bar{t}}{\left.\varepsilon_{p}+\left(1-\varepsilon_{p}\right) K\right]}+\frac{1}{\varepsilon}+\frac{k_{p} a_{t} \bar{t}(1-\varepsilon)}{\varepsilon} \\
& c_{1}=\frac{k_{p} a_{t} \bar{t}}{\varepsilon\left[\varepsilon_{p}+\left(1-\varepsilon_{p}\right) K\right]} \\
& A_{13}=\frac{(1-\varepsilon) k_{p} a_{t} \bar{t}}{\varepsilon\left[\varepsilon_{p}+\left(1-\varepsilon_{p}\right) K\right] \cdot\left[g_{1}-g_{2}\right]}
\end{aligned}
$$

gde su:

$$
\begin{array}{ll}
A_{13} & \text { parametar u modelu (26), koji se računa prema izrazu (30), } \\
g_{1,2} & \text { parametri modela (26), koji se računa prema izrazu (27), } \\
a_{t} & \text { specifična površina čestica u ekstraktoru }\left(\mathrm{m}^{2} / \mathrm{m}^{3}\right), \\
\varepsilon_{p} & \text { poroznost čestica }\left(\mathrm{m}^{3} / \mathrm{m}^{3}\right) .
\end{array}
$$

Catchpole i Grey (1996) razvili su novi model na osnovu modela koji su predložili Goto i saradnici (1993), koji je primenjivan kod ekstrakcije žalfije, celera i semena korijandera. Model sadrži samo jedan nepoznati parametar, koeficijent difuzije $\mathrm{D}_{e}$ koji je konstantan za svaku pojedinačnu biljku. Izmenjeni model (jednačina (31)) je primenjiv za sve visine ekstraktora:

$\mathrm{Y}_{\mathrm{E}}=x_{0}\left[1-\exp \left(-n_{\text {čs }}\left(n_{\check{c} e s}+2\right) D_{e} \frac{t-\frac{h_{E} \varepsilon}{u_{i}}}{R_{p}^{2}}\right)\right]$

gde je:

$$
\begin{array}{ll}
\mathrm{n}_{\check{c e s}} & \text { faktor oblika čestice }(\mathrm{n}=1 \text { za oblik ploče, za valjak } \mathrm{n}=2 \text {, dok je za loptu } \\
& \mathrm{n}=3), \\
\mathrm{u}_{i} & \text { protok }(\mathrm{m} / \mathrm{s}),
\end{array}
$$


$\mathrm{h}_{E} \quad$ visina ekstraktora $(\mathrm{m})$,

$\mathrm{D}_{e} \quad$ efektivni koeficijent difuzije $\left(\mathrm{m}^{2} / \mathrm{s}\right)$.

\subsubsection{Model pojedinačne sfere}

U modelu pojedinačne sfere (eng. Single Sphere Model - SSM) pretpostavlja se da se rastvorak ekstrahuje iz sloja koji se sastoji od poroznih inertnih sfera jednakih veličina i da je srednja koncentracija rastvorka u svakoj od sfera ista u svakom trenutku procesa (Reverchon i sar., 1993, Reverchon i sar., 1994). Koncentracija rastvorka u čestici je uniformna na početku procesa, a koncentracioni profil ostaje sferno simetričan tokom procesa. Takođe, pretpostavlja se da je koncentracija rastvorka u masi fluida zanemarljiva, što je posledica dovoljno velike brzine strujanja rastvarača oko čestice. Kada se primenjuje model pojedinačne sfere, najčešce se smatra da se ekstrakt sastoji od jedne pseudo-komponente. Rastvarač se kroz sloj punjenja materijala u ekstraktoru kreće mehanizmom „sličnim difuziji“. U modelima pojedinačne sfere mogu se, pored otpora unutrašnjem prenosu mase, uzimati u obzir ili zanemariti otpori prenosu mase u filmu rastvarača (fluida) koji okružuje česticu.

Jednačina (32) je matematički analogna sa prenosom toplote, odnosno hlađenjem vrele sfere uronjene u hladan fluid, pa se može uporediti sa prenosom mase sa čestica oblika sfere na fluid u kojem nema rastvorka, pri čemu je prenos mase definisan Fick-ovim zakonom. Postoji analogija prenosa mase i prenosa toplote u sledeća dva slučaja:

$\dot{m}_{e p}=-\rho_{s} x_{0} D_{e}\left(\frac{1}{r^{2}} \frac{\partial\left(r^{2} X\right)}{\partial r}\right)$

gde su:

$\begin{array}{ll}\dot{m}_{e p} & \text { maseni protok fluida po jedinici površine }\left(\mathrm{kg} / \mathrm{cm}^{2}\right), \\ X & \text { bezdimenzionalna koncentracija }(-), \\ D_{e} & \text { efektivni koeficijent difuzije }\left(\mathrm{m}^{2} / \mathrm{s}\right), \\ r & \text { poluprečnik }(\mathrm{m}), \\ x_{0} & \text { početni sadržaj rastvorka }(\mathrm{kg} / \mathrm{kg}) .\end{array}$

Iz analitičkog rešenja jednačine (32) koja se dobija primenom Furijeovih transformacija i analogije prenosa mase i toplote, izvodi se zavisnost ukupnog prinosa po jedinici površine (Wong, 1977): 
$\mathrm{m}_{e p}=4 R_{p}\left(\rho_{s} x_{0}-\rho_{f} y\right)\left[\sum_{k=1}^{\infty} \frac{\left(\sin \beta_{k}-\beta_{k} \cos \beta_{k}\right)^{2}}{\beta_{k}^{3}\left(2 \beta_{k}-\sin 2 \beta_{k}\right)}\left(1-\exp \left(\left(\frac{\beta_{k}}{R_{p}}\right)^{2}\left(-D_{e} t\right)\right)\right)\right]$

gde je:

$\mathrm{m}_{e p} \quad$ masa ekstrahovane supstance po jedinici površine $\left(\mathrm{kg} / \mathrm{m}^{2}\right)$,

$R_{p} \quad$ poluprečnik čestice (m).

Uzimajući u obzir da je ekstraktor ispunjen elementarnim česticama i da je koncentracija rastvorka u fluidnoj fazi zanemarljiva (Esquivel i sar., 1999), prinos ekstrakta $\left(\mathrm{Y}_{\mathrm{E}}\right)$ u funkciji vremena $(t)$ data je sledećom jednačinom:

$\mathrm{Y}_{\mathrm{E}}=x_{0}\left[12 \sum_{k=1}^{\infty} \frac{\left(\sin \beta_{k}-\beta_{k} \cos \beta_{k}\right)^{2}}{\beta_{k}^{3}\left(2 \beta_{k}-\sin 2 \beta_{k}\right)}\left(1-\exp \left(\left(\frac{\beta_{k}}{R}\right)^{2}\left(-D_{e} t\right)\right)\right)\right]$

$\beta_{k} \cos \beta_{k}=1-\frac{k_{f} R}{D_{e}}$

gde je:

$\mathrm{k}_{f} \quad$ koeficijent prenosa mase u fluidnoj fazi $(\mathrm{m} / \mathrm{s})$,

$\beta_{k} \quad$ vrednost svakog člana serije u jednačini (35).

Jednačina (34) se može pojednostaviti i dobiti sledeći izraz

$$
m_{e x t}=x_{0} F\left(\frac{t}{b+t}\right)
$$

gde je:

$$
\begin{array}{ll}
F & \text { masa čvrstog materijala }(\mathrm{kg}), \\
t & \text { vreme ekstrakcije }(\mathrm{h}), \\
x_{0} & \text { početni sadržaj rastvorljive supstance }(\mathrm{kg} / \mathrm{kg}), \\
b & \text { podesiv parametar }(\mathrm{s}) .
\end{array}
$$

Esquivel i saradnici (1999) su ovaj model primenili za modelovanje ekstrakcije ulja iz koštica masline superkritičnim ugljendioksidom.

Kako bi se izračunala vrednost $\beta_{k}$ potrebno je odrediti spoljašnji koeficijent prenosa mase $\mathrm{k}_{f}$ i efektivni koeficijent difuzije $D_{e}$. Reverchon i saradnici (1993) su predložili da se spoljašnji koeficijent prenosa mase određuje prema Sherwood-ovoj jednačini ukoliko je poznata vrednost $D_{f}$. Koeficijent difuzije koristi se kao parametar modela kako bi se postigla najbolja slaganja sa eksperimentalnim rezultatima. 


\subsubsection{Model karakterističnog vremena}

U slučajevima kada unutrašnji prenos mase kontroliše proces, pojednostavljenje problema može se postići uvođenjem aproksimacije modela linearne pogonske sile. Uvođenje ove aproksimacije je moguće kada nije potrebno definisati raspodelu koncentracija rastvorka unutar čestice, nego znati samo srednju koncentraciju rastvorka u čestici. Reverchon i Sesti Ossèo (1994) su po ovom modelu modelovali ekstrakciju bosiljka natkritičnim ugljendioksidom. Autori su iz opšteg modela isključili disperziju rastvorka u fluidnoj fazi i opisali problem modelom u kome unutrašnji prenos mase kontroliše proces i onda ga zamenili sa matematički ekvivalentnim modelom u kojem spoljašnji prenos mase kontroliše proces.

Prinos ekstrakta se može izraziti sledećom jednačinom:

$\mathrm{Y}_{\mathrm{E}}=1-\exp \left(\frac{-k_{p} t}{\frac{(1-\varepsilon) V \rho}{W}+k_{p} t_{i}}\right)$

gde su:

$\begin{array}{ll}k_{p} & \text { kombinovani koeficijent prenosa mase }(\mathrm{m} / \mathrm{s}), \\ \varepsilon & \text { poroznost sloja materijala u ekstraktoru }\left(\mathrm{m}^{3} / \mathrm{m}^{3}\right), \\ V & \text { zapremina ekstraktora }\left(\mathrm{m}^{3}\right), \\ \rho & \text { gustina rastvarača }\left(\mathrm{kg} / \mathrm{m}^{3}\right), \\ t_{i} & \text { vreme unutrašnje difuzije }(\mathrm{s}), \\ W & \text { protok rastvarača }(\mathrm{kg} / \mathrm{s}) .\end{array}$

Kako je unutrašnja difuzija jedini limitirajući faktor, jednačina (37) se može uprostiti:

$\mathrm{Y}_{\mathrm{E}}=1-\exp \left(-\frac{t}{t_{i}}\right)$

\subsubsection{MODEL POJEDINAČNE PLOČE}

Gaspar i saradnici (2003) razvili su tri modela za opisivanje procesa superkritične ekstrakcije etarskog ulja iz lista origana. Modele su razvili na osnovu pretpostavke da su čestice oblika ploče, a ne sfernog oblika.

Prvi model (eng. Single Simple Plate model - SSP), koji su prvo predložili Bartle i saradnici (1990), modifikovan je u skladu sa sledećim pretpostavkama: 
- ekstrahovano ulje je ravnomerno raspoređeno unutar čestica oblika ploče;

- u određenom trenutku sve čestice se nalaze u istom periodu ekstrakcije;

- unutrašnji prenos mase je opisan procesom difuzije kroz česticu;

- koncentracija supstance u gasovitoj fazi je zanemarljiva u odnosu na čvrstu fazu;

- otpor prenosu mase na granici filma je zanemarljiv;

- ekstrahovana masa iz sloja punjenja materijala jednaka je ekstrahovanoj masi iz čestica.

Uzimajući u obzir navedene pretpostavke, predložen je prvi model:

$$
\mathrm{Y}_{\mathrm{E}}=\mathrm{x}_{\mathrm{o}}\left[1-\sum_{j=0}^{\infty} \frac{8}{(2 j+1)^{2}} \exp \left(\frac{\left(-D(2 j+1)^{2} j^{2} t\right)}{\delta_{p}^{2}}\right)\right]
$$

gde je:

$$
\begin{array}{ll}
D & \text { koeficijent difuzije }\left(\mathrm{m}^{2} / \mathrm{s}\right), \\
\delta_{p} & \text { debljina sloja čestica }(\mathrm{m}) .
\end{array}
$$

Drugi model (eng. Single Plate model - SP) ima iste pretpostavke kao i prethodni SSP model, s tim što se kod ovog modela spoljašnji otpor prenosa mase ne zanemaruje. Ovaj model je sličan jednostavnom modelu pojedinačne sfere, $s$ tom razlikom što su čestice oblika ploče, a ne sfere. Prinos ekstrakta $\left(\mathrm{Y}_{\mathrm{E}}\right)$ se u ovom slučaju izračunava:

$\mathrm{Y}_{\mathrm{E}}=\mathrm{x}_{\mathrm{o}}\left(4 \sum_{n=1}^{\infty} \frac{\sin ^{2} \beta_{n}}{2 \beta_{n}^{2}+\beta_{n} \sin 2 \beta_{n}}\left[1-\exp \left(-\left(\frac{2 \beta_{n}}{\delta_{p}}\right)^{2} D \cdot t\right)\right]\right)$

$\beta_{\mathrm{n}} \tan \beta_{\mathrm{n}}=\frac{k_{f} \delta_{p}}{2 D}$

gde je:

$\begin{array}{ll}\beta_{n} & \text { pozitivni koren implicitne jednačine, } \\ k_{f} & \text { koeficijent prenosa mase u gasovitoj fazi }(\mathrm{m} / \mathrm{s}) .\end{array}$

Treći model (eng. Fluid Phase/Simple Single Plate model - FP/SSP) koji se bazira na činjenici da unutrašnja difuzija određuje brzinu ekstrakcije, pretpostavlja da je na početku ekstrakcije deo rastvorljive supstance ravnomerno respoređen u gasovitoj fazi, dok je drugi deo supstance ravnomerno raspoređen unutar čestica oblika ploče. Unutrašnji prenos mase može se u ovom slučaju opisati SSP modelom. Model pretpostavlja da su aksijalna disperzija, gustina fluida i poroznost sloja punjenja kolone konstantne vrednosti u svakoj tački sloja i nazavisne od vremena ekstrakcije. Prinos ekstrakta je izražen sledećom jednačinom: 
$\mathrm{Y}_{\mathrm{E}}=\frac{\int_{0}^{t} \rho_{f} y\left(h=H_{t}, t\right) \cdot u_{s} A_{E} d t}{x_{0} m_{s}}$

gde su:

$\begin{array}{ll}A_{E} & \text { površina sloja punjenja materijala u ekstraktoru }\left(\mathrm{m}^{2}\right), \\ H_{t} & \text { visina sloja punjenja materijala u ekstraktoru }(\mathrm{m}) .\end{array}$

$\rho_{f} \frac{\partial y}{\partial t}=\rho_{f} \frac{D_{a y}}{\varepsilon} \frac{\partial^{2} y}{\partial h^{2}}-\rho_{f} \frac{u_{s}}{\varepsilon} \frac{\partial y}{\partial h}+\frac{x_{0} m_{s}}{A_{E} H_{t} \varepsilon} \sum_{j=0}^{\infty} \frac{8 D}{\delta_{p}^{2}} \exp \left(-D \cdot t \cdot\left[\frac{(2 j+1) \pi}{\delta_{p}}\right]^{2}\right)$

gde su:

$h \quad$ aksijalna koordinata sloja punjenja u ekstraktoru (m),

$D_{a y} \quad$ koeficijent aksijalne disperzije $\left(\mathrm{m}^{2} / \mathrm{s}\right)$.

Koncentracija na izlazu sloja punjenja materijala u ekstraktoru potrebna za izračunavanje prinosa ekstrakta, dobija se pomoću izraza:

$\mathrm{y}_{\mathrm{o}}=\frac{q x_{0} m_{s}}{A_{E} H_{t} \varepsilon \rho_{f}}$

\subsubsection{DVOSTEPENI MODELI}

Deo biljnih ćelija iz kojih se ekstrahuje rastvorak biva razoren mlevenjem u procesu usitnjavanja semena. Na površini i u blizini površine čestice usitnjenog materijala većina čestica je razorena, dok unutrašnjost čestice sačinjavaju nerazorene ćelije. Zapreminski udeo razorenih ćelija u česticama usitnjenog materijala naziva se efikasnost mlevenja $\left(\mathrm{e}_{\mathrm{m}}\right)$ (Sovová, 1994). Može se smatrati da je rastvorak (ulje) u čvrstom materijalu prisutan u dve različite faze, kao slobodan i vezani rastvorak. Rastvorak iz razorenih ćelija je lako dostupan slobodan rastvorak. Nalazi se na površini čestica i direktno se prenosi u fluidnu fazu (rastvarač). Rastvorak zatvoren u unutrašnjoj strukturi nerazorenih ili delimično razorenih čestica predstavlja fazu vezanog rastvorka (eng. tied solute), koji iz nerazorenih ćelija prvo difunduje ka razorenim ćelijama, a zatim se prenosi u fluidnu fazu. Ekstrahovana količina lako dostupnog rastvorka je ograničena njegovom rastvorljivošću u rastvaraču pri uslovima procesa, a brzina njegove ekstrakcije je ograničena brzinom spoljašnjeg prenosa mase. Prenos mase iz razorenih čelija ka rastvaraču opisuje se koeficijentom prenosa mase u fluidnoj fazi ili 
koeficijentom spoljašnjeg prenosa mase $\left(\mathrm{k}_{\mathrm{f}}\right)$. Ovaj koeficijent je nekoliko redova veličina veći od koeficijenta prenosa mase u čvrstoj fazi ili koeficijenta unutrašnjeg prenosa $\left(\mathrm{k}_{\mathrm{s}}\right)$, kojim se opisuje prelaz rastvorka iz nerazorenih ka razorenim ćelijama. Brzinu ekstrakcije vezanog rastvorka kontroliše mehanizam unutrašnjeg prenosa mase (Nikolovska, 2009).

Iz biljnog materijala se prvo uklanja lako dostupan rastvorak, a zatim se ekstrahuje rastvorak iz nerazorenih ćelija, pri čemu je to najsporiji proces, jer je rastvorak zaštićen ćelijskim zidom.

U prvoj fazi ekstrakcije, kada je brzina rastvarača kroz sloj mala, a koncentracija rastvorka zaostalog u materijalu još uvek velika, rastvorak se ekstrahuje sa površine materijala konstantnom brzinom (Brunner, 1984). U drugoj fazi procesa brzina ekstrakcije se smanjuje, što je posledica uklanjanja slobodnog rastvorka sa površine čestica, pri čemu je brzina druge faze ekstrakcije ograničena brzinom unutrašnje difuzije. Ova faza značajno produžava vreme trajanja procesa ekstrakcije.

\subsubsection{Sovová model}

Sovová (1994) je razvila dvostepeni model koji je proširenje modela klipnog toka (Lack, 1985). Prošireni Lack-ov model (eng. Extended Lack’s Model) sadrži oba koeficijenta prenosa mase, spoljašnji i unutrašnji. U ukupni otpor prenosu mase uključeni su otpori prenosu mase u filmu rastvarača koji okružuje česticu i u unutrašnjosti čestice.

Ovaj model definiše tri ekstrakciona perioda. U početnom periodu ekstrakcija se odvija konstantnom brzinom i određena je otporom filma nadkritičnog fluida. Na kraju ovog perioda čestice na mestu ulaska fluida u ekstraktor ostaće bez slobodnog rastvorka. Međutim, rastvorak koji je smešten u unutrašnjosti čestice ostaje prisutan u ovim česticama i ekstrahuje se u drugom periodu. U drugom periodu slobodan rastvorak se uklanja i sa površine svih ostalih čestica, tj. i one postaju delimično iscrpljene. U poslednjem, trećem ekstrakcionom periodu, ekstrahuje se rastvorak koji je smešten dublje u unutrašnjost ćelije, gde je glavni mehanizam prenosa mase difuzija (slika 19). 


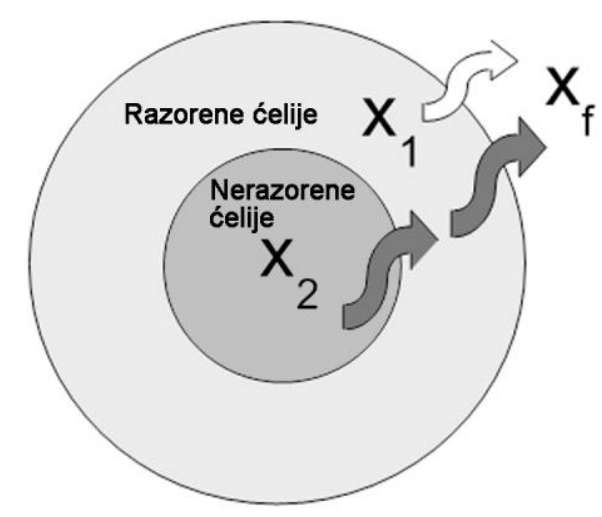

Slika 19. Šema čestice prema Sovová modelu

Prenos mase tokom procesa ekstrakcije može se opisati sledećim izrazom (Sovová, 1994, Sovová i sar., 1994):

$\left.-\rho_{s}(1-\varepsilon) \frac{\partial x}{\partial t}\right)=J(x, y)$

$\rho_{f} \varepsilon \frac{\partial y}{\partial t}+\rho_{f} u_{s} \frac{\partial y}{\partial h_{E}}=J(x, y)$

gde su:

$J \quad$ specifična brzina prenosa mase $\left(\mathrm{kg} / \mathrm{m}^{3} \mathrm{~s}\right)$,

$\rho_{f}, \rho_{s} \quad$ gustina superkritičnog fluida i gustina čestica materijala $\left(\mathrm{kg} / \mathrm{m}^{3}\right)$,

$h_{E} \quad$ visina ekstraktora (m),

$t \quad$ vreme ekstrakcije (s),

$u_{s} \quad$ linearna brzina strujanja fluida $(\mathrm{m} / \mathrm{s})$,

$\varepsilon \quad$ poroznost sloja materijala $\left(\mathrm{m}^{3} / \mathrm{m}^{3}\right)$,

$x, y \quad$ bezdimenzionalna koncentracija čvrste i gasovite faze $(\mathrm{kg} / \mathrm{kg})$.

Prinos ekstrakta se računa po sledećoj formuli:

$\mathrm{Y}_{\mathrm{E}}(\mathrm{t})=x_{o}-\frac{1}{H_{t}} \int_{0}^{H_{t}} x(h, t) \cdot d h$

$\mathrm{Y}_{\mathrm{E}}(\mathrm{t})=\frac{m_{f}}{m_{s}} \int_{0}^{t} y\left(H_{t}, t\right) \cdot d t$

gde su:

$\mathrm{Y}_{\mathrm{E}} \quad$ prinos ekstrakta $(\%)$,

$H_{t} \quad$ visina sloja punjenja materijala u ekstraktoru (m),

$m_{f} \quad$ maseni protok $\mathrm{CO}_{2}(\mathrm{~kg} / \mathrm{s})$, 
$m_{s} \quad$ masa materijala u ekstraktoru $(\mathrm{kg})$.

U prvom periodu ekstrakcije gde se lako rastvorljiva supstanca nalazi na površini čestica važi sledeća relacija:

$$
J(x, y)=k_{f} a_{t} \rho_{f}\left(y^{*}-y\right) \quad \text { ako je } \quad x>(1-q) x_{\mathrm{o}}
$$

gde su:

$k_{f} \quad$ koeficijent prenosa mase u gasovitoj fazi $(\mathrm{m} / \mathrm{s})$,

$a_{t} \quad$ specifična površina čestica u ekstraktoru $\left(\mathrm{m}^{2} / \mathrm{m}^{3}\right)$,

$y^{*} \quad$ rastvorljivost komponente u superkritičnom fluidu ( $\mathrm{kg}$ supstance/kg $\left.\mathrm{CO}_{2}\right)$,

$q$ specifična potrošnja rastvarača po jedinici mase neekstraktibilnih komponenata materijala $(\mathrm{kg} / \mathrm{kg})$.

U drugom periodu ekstrakcije, kada više nema lako rastvorljive supstance na površini čestice, već se ona nalazi u unutrašnjosti (gde je difuzija glavni mehanizam prenosa mase) može se primeniti sledeća relacija:

$J(x, y)=k_{s} a_{t} \rho_{s}\left(x-x_{f}\right) \quad$ ako je $\quad x \leq(1-q) x$

gde je:

$k_{s} \quad$ koeficijent prenosa mase u čvrstoj fazi $(\mathrm{m} / \mathrm{s})$,

$x_{f} \quad$ koncentracija rastvorljive supstance na površini čvrstih čestica $\left(\mathrm{kg} / \mathrm{m}^{3}\right)$.

Kako je otpor difuziji u čvrstoj fazi puno veći od otpora u superkritičnoj fazi, površinska koncentracija $x_{\mathrm{f}}$ može se zanemariti u poređenju sa koncentracijom unutar čestica $x\left(x_{f}<<x\right)$, pa se prethodna jednačina može napisati kao:

$J(x, y)=k_{s} a_{t} \rho_{s} x \quad$ ako je $\quad x \leq(1-q) x_{o}$

Lack (1985) je takođe brzinu prenosa mase tokom brzog perioda ekstrakcije opisao pomoću jednačine (49) i predložio sledeću relaciju:

$$
J(x, y)=k_{f} a_{t} \rho_{f}\left(y^{*}-y\right) \frac{x}{q x_{o}} \quad \text { ako je } \quad x \leq(1-q) x_{o}
$$

Cygnarowicz-Provost i saradnici (1992) predložili su sledeću jednačinu kojom se opisuje period brze ekstrakcije:

$$
J(x, y)=k_{f} a_{t} \rho_{f}\left(y^{*}-y\right) \exp \left[\ln (0,001) \frac{x_{o}-x}{x_{o}(1-q)}\right]
$$

Sovová (1994) je predložila analitičko rešenje za drugu fazu ekstrakcije:

$$
J(x, y)=k_{s} a_{t} \rho_{s} x\left(1-\frac{y}{y^{*}}\right) \quad \text { ako je } \quad x \leq(1-\mathrm{q}) x_{o}
$$


Kako Sovová model definiše tri ekstrakciona perioda (konstantni period ekstrakcije, prelazni period ekstrakcije i period difuzije), to se količine ekstrahovanih supstanci koje se dobijaju tokom prvog, drugog i trećeg perioda ekstrakcije mogu opisati sledećim jednačinama:

$\frac{Y_{E}}{x_{o}}=\vartheta[1-\operatorname{exo}(-Q)]$ ako je $\vartheta<\frac{q}{Q}$

$\frac{Y_{E}}{x_{o}}=\vartheta-\frac{q}{Q} \exp \left[Q\left(Z_{k}-1\right)\right]$ ako je $\frac{q}{Q} \leq \vartheta<\vartheta_{k}$

$\frac{Y_{E}}{x_{o}}=1-\frac{1}{S} \ln \left\{1+[\exp (S)-1] \exp \left[S\left(\frac{q}{Q}-\vartheta\right)\right](1-q)\right\} \quad$ ako je $\vartheta \geq \vartheta_{k}$

\subsubsection{Model koji je adaptirao Reverchon}

Reverchon je sa grupom saradnika adaptirao Lack-ov model klipnog toka, pri čemu je dobijen novi model (Marrone i sar., 1998, Reverchon i sar., 2001). Brzina ekstrakcije ulja dobija se kao suma brzine ekstrakcije slobodnog i brzine ekstrakcije vezanog ulja. Pretpostavlja se da je brzina ekstrakcije slobodnog ulja proporcionalna koeficijentu spoljašnjeg prenosa mase, a pogonska sila jednaka razlici između gustine ulja $\left(\rho_{u}\right)$ i koncentracije ulja u zasićenom superkritičnom fluidu. Brzina ekstrakcije vezanog ulja proporcionalna je koeficijentu unutrašnjeg prenosa mase, a pogonska sila jednaka razlici između stvarne koncentracije vezanog ulja u čvrstoj fazi i ravnotežne koncentracije rastvorka u kontaktu sa fluidom u ekstraktoru. Dve ravnotežne koncentracije su definisane sa dva različita koeficijenta raspodele:

$\mathrm{K}_{\mathrm{su}}=\mathrm{c}_{\mathrm{sat}} / \rho_{u}$ - koeficijent raspodele između slobodnog ulja u čvrstoj fazi i rastvorenog ulja;

$\mathrm{K}_{\mathrm{vu}}=\mathrm{c}_{\mathrm{sat}} / \mathrm{c}_{\mathrm{vuo}}$ - koeficijent raspodele između vezanog ulja $\mathrm{u}$ čvrstoj fazi i rastvorenog ulja $\mathrm{u}$ fluidu.

Brzina ekstrakcije (J) određuje se iz sledeće jednačine:

$\mathrm{J}=k_{f}\left(\rho_{u}-\frac{c_{f}}{K_{s u}}\right)+k_{s}\left(c_{v u}-\frac{c_{f}}{K_{v u}}\right)$

Reverchon i Marrone (2001) su ovaj model primenili za modelovanje ekstrakcije semena suncokreta, korijandera, semena grožđa, paradajza, kikirikija, badema i semena mirođije. 


\subsection{ANTIOKSIDANTI I ANTIOKSIDATIVNO DEJSTVO}

Termin ,antioksidant“ podrazumeva sve supstance koje u koncentracijama znatno nižim od koncentracije supstrata koji može da se oksiduje, značajno smanjuje ili sprečava njegovu oksidaciju (Halliwell i sar., 1995). Značaj antioksidanata je u tome što štite prehrambene, kozmetičke i farmaceutske proizvode od oksidativne degradacije. Aktivnost antioksidanata zavisi ne samo od njihove strukture, nego i od mnogih drugih faktora, kao što su koncentracija, temperatura, svetlost, tip substrata, fizičko stanje sistema, kao i prisustvo mikrokomponenata koje deluju kao prooksidanti ili sinergisti (Yanishlieva-Maslarova i sar., 2001).

Neki antioksidanti se sintetišu u organizmu (endogeni), a drugi (egzogeni) se unose hranom ili konzumiranjem dijetetskih suplemenata. Grupu endogenih antioksidanata čine enzimi (superoksid-dismutaza, katalaza, peroksidaze, glutation-reduktaza, ksantin-oksidaza i dr.) koji metabolišu superoksid anjon radikal, vodonik peroksid i lipidne perokside, neenzimski molekuli (glutation, transferin, dihidrolipoinska kiselina, redukovani oblik koenzima Q, melatonin i drugi), kao i neki hemijski elementi (cink i selen). Ovi sistemi sinergistički deluju u suzbijanju stvaranja slobodnih radikala ili prekidaju lančane reakcije koje su inicirane od strane slobodnih radikala (,hvatači“ slobodnih radikala). No, i pored postojanja endogenih - odbrambenih antioksidanata do određenih oštećenja ipak dolazi (arterioskleroza, kancer, šlog, astma, artritis i druge bolesti koje su povezane sa starenjem). Zbog ograničene efikasnosti endogenih odbrambenih sistema i postojanja patofizioloških faktora (UV i jonizujuće zračenje, pušenje, hrana bogata polinezasićenim masnim kiselinama, inflamatorni procesi, lekovi, pesticidi, itd.) koji doprinose stvaranju slobodnih radikala, neophodno je hranom ili na neki drugi način, uneti egzogene antioksidante (Radojković, 2012).

Najznačajniji egzogeni antioksidanti su vitamini C, E i A, karotenoidi, polifenoli i drugi (Pietta, 2000, Fang i sar., 2002). Neki od njih su najranije poznati biološki antioksidanti. Prirodni antioksidanti se javljaju u svim delovima biljaka. Oni sprečavaju dejstvo kiseonika, hvataju slobodne radikale, razlažu perokside, sprečavaju dejstvo enzima i deluju sinergistički (Manach i sar., 2004).

Poslednjih godina velika pažnja se posvećuje ispitivanju biljnih fenola koji predstavljaju značajna jedinjenja u zaštiti od oksidativnog stresa. Fenolna jedinjenja obuhvataju široku grupu supstanci koje u svojoj strukturi imaju aromatičan prsten sa jednom ili više hidroksilnih grupa. Od nekoloko hiljada fenolnih jedinjenja većina je biljnog porekla (Strack, 1997). Biljna 
fenolna jedinjenja su klasifikovana prema strukturnoj kompleksnosti i biosintetičkom poreklu, ali nijedan sistem njihove podele nije dovoljno precizan (Harborne i sar., 1999). Klasifikacija prirodnih fenolnih jedinjenja po Robardsu i saradnicima (2000) data je u tabeli 10.

Veliki interes za prirodne antioksidante rezultat je svetskog trenda minimiziranja ili potpunog eliminisanja sintetičkih antioksidanata zbog njihovog štetnog dejstva. Začini i biljke u hrani kao lek postali su izuzetno interesantni zbog unosa antioksidanata koji pozitivno utiču na zdravlje.

Tabela 10. Podela fenolnih jedinjenja

\begin{tabular}{|c|c|c|}
\hline Osnovni skelet & Klasa & Primer \\
\hline \multirow{2}{*}{ C6 } & Prosti fenoli & Katehol, hidrohinon, rezorcinol \\
\hline & Benzohinoni & \\
\hline C6-C1 & Fenolne kiseline & $\begin{array}{l}p \text {-Hidroksibenzoeva kiselina, salicilna } \\
\text { kiselina }\end{array}$ \\
\hline \multirow[t]{2}{*}{$\mathrm{C} 6-\mathrm{C} 2$} & $\begin{array}{l}\text { Fenilsirćetne } \\
\text { kiseline }\end{array}$ & p-Hidroksifenilsirćetna kiselina \\
\hline & Cimetne kiseline & Kafena kiselina, ferulna kiselina \\
\hline \multirow{3}{*}{ C6-C3 } & Fenilpropeni & Eugenol, miristicin \\
\hline & Kumarini & Umbeliferon, eskuletin, skopolin \\
\hline & Hromoni & Eugenin \\
\hline C6-C4 & Naftohinoni & Juglon \\
\hline C6-C1-C6 & Ksantoni & Mangostin, mangiferin \\
\hline \multirow{7}{*}{ C6-C2-C6 } & Stilbeni & Rezveratrol \\
\hline & Antrahinoni & Emodin \\
\hline & Flavonoidi & \\
\hline & Flavoni & $\begin{array}{l}\text { Apigenin, luteolin, sinensetin, nobiletin, } \\
\text { izosinensitin, tangeretin, diosmin }\end{array}$ \\
\hline & Flavonoli & Kvercetin, kamferol \\
\hline & Flavonol glikozidi & Rutin \\
\hline & Flavanoli & Dihidrokvercetin i dihidrokamferol glikozidi \\
\hline \multirow{5}{*}{ C6-C3-C6 } & Flavanoni & Hesperidin, naringenin \\
\hline & Flavanon glikozidi & $\begin{array}{l}\text { Hesperidin, neohesperidin, narirutin, naringin, } \\
\text { eriocitrin }\end{array}$ \\
\hline & Antocijanini & $\begin{array}{l}\text { Glikozidi pelargonidina, peonidina, } \\
\text { delfinidina, petunidina, cijanidina }\end{array}$ \\
\hline & Flavanoli (katehini) & $\begin{array}{l}\text { Katehin, epikatehin, galokatehin, } \\
\text { epigalokatehin }\end{array}$ \\
\hline & Halkoni & Floridžin, arbutin, halkonaringenin \\
\hline \multirow{2}{*}{$\begin{array}{l}(\mathrm{C} 6-\mathrm{C} 3)_{2} \\
(\mathrm{C} 6-\mathrm{C} 3-\mathrm{C} 6)_{2}\end{array}$} & Lignini & Pinorezinol \\
\hline & Biflavonoidi & Agatisflavon, amentoflavon \\
\hline
\end{tabular}


Biljne vrste familije Lamiaceae, poput ruzmarina, žalfije, izopa, origana, timijana i bosiljka, poznate su po svojim antioksidativnim svojstvima (Terens i sar., 1995, Manaker i sar., 2004). Ispitivanja antioksidativne aktivnosti ekstrakta iz biljnih vrsta familije Lamiaceae pokazala su da imaju ekvivalentno (Đarmati i sar., 1991) ili jače antioksidativno dejstvo od sintetičkih antioksidanata. 


\section{REZULTATI I DISKUSIJA}

Ispitivanja herbe bosiljka obuhvatala su određivanje osobina polaznog materijala, pripremu uzorka za ekstrakciju, hidrodestilaciju, Soxhlet ekstrakciju metilen-hloridom i ekstrakciju superkritičnim ugljendioksidom. Superkritičnom ekstrakcijom uz variranje parametara procesa (temperatura, pritisak, tj. gustina ekstragensa) ispitana je kinetika ekstrakcije i prinos izdvojenih ekstrakata. Sukcesivnom ekstrakcijom (frakcionisanjem), variranjem uslova ekstrakcije, je ispitana takođe, kinetika ekstrakcije uz praćenje prinosa izdvojenih frakcija. Kvalitativnom i kvantitativnom analizom (GC/MS i GC/FID) etarskog ulja i ekstrakata bosiljka određen je hemijski sastav i sadržaj detektovanih komponenata. Matematičkim modelovanjem ispitivanog ekstrakcionog sistema primenom tri modela određeni su parametri ispitivanih modela $\mathrm{u}$ cilju najboljeg slaganja modela sa eksperimentalnim podacima. Ispitivanje delovanja etarskog ulja i ekstrakata obuhvatalo je evaluaciju antioksidativne aktivnosti praćenjem sposobnosti neutralizacije slobodnih radikala.

\subsection{ISPITIVANJE OSOBINA POLAZNOG MATERIJALA}

Za istraživanje u ovom radu korišćeni su listovi i cvetovi bosiljka (O. basilicum L.). Mlevenjem biljnog materijala $\mathrm{i}$ analizom sejanjem određen je srednji prečnik čestica usitnjenog materijala koji iznosi $0,657 \mathrm{~mm}$. U ispitivanom biljnom materijalu sadržaj vlage je iznosio $11,44 \pm 0,05 \%$ i nalazi se u granicama propisanim Farmakopejom (Ph. Jug. V). Hidrodestilacijom je određen sadržaj etarskog ulja (EO) u drogi koji iznosi 0,565\%, i u granicama je koje propisuje literatura (Tucakov, 1990). Sadržaj ukupnih ekstraktivnih materija je određen Soxhlet ekstrakcijom primenom metilen-hlorida, pri čemu je dobijen prinos od $1,95 \%(\mathrm{~m} / \mathrm{m})$. Rezultati ispitivanja osobina polaznog matrijala, sadržaja etarskog ulja i sadržaja ukupnih ekstraktivnih materija dati su u tabeli 11.

Tabela 11. Rezultati ispitivanja polaznog biljnog materijala

\begin{tabular}{|l|c|}
\hline Uzorak & Ocimum basilicum L. \\
\hline Sradnji prečnik čestica (mm) & 0,657 \\
\hline Sadržaj vlage (\%, m/m) & $11,44 \pm 0,05$ \\
\hline Sadržaj etarskog ulja (\%, v/m) & 0,565 \\
\hline $\begin{array}{l}\text { Ukupan sadržaj ekstraktivnih materija } \\
(\%, \mathbf{m} / \mathbf{m})\end{array}$ & 1,95 \\
\hline
\end{tabular}




\subsection{GC/MS ANALIZA ETARSKOG ULJA BOSILJKA}

Etarsko ulje bosiljka (Basilici aetheroleum) dobijeno hidrodestilacijom ispitivano je u odnosu na kvalitativni i kvantitativni sastav primenom GC/MS i GC/FID metoda (poglavlje 4.7.). Dobijeni rezultati dati su u tabeli 12, a hromatogram etarskog ulja bosiljka je prikazan na slici 20.

Ukupno je identifikovano 25 komponenata čije je udeo 95,66\%. Detektovane komponente se mogu podeliti u pet grupa: monoterpenski ugljovodonici, oksidovani monoterpeni, aromatični oksidovani monoterpeni, seskviterpenski ugljovodonici i oksidovani seskviterpeni. Najzastupljenija hemijska grupa su oksidovani monoterpeni sa 55,84\%. Ostale grupe su manje zastupljene: seskviterpenski ugljovodonici 30,77\%, aromatični oksidovani monoterpeni $7,06 \%$, monoterpenski ugljovodonici $1,26 \%$ i oksidovani seskviterpeni $0,73 \%$ (slika 21).

Na osnovu dobijenih rezultata kvalitativne i kvantitativne GC-MS analize (tabela 12) može se zaključiti da je dominantno jedinjenje u etarskom ulju bosiljka linalool sa relativnim udelom 50,09\% (GC-MS), odnosno sa sadržajem u etarskom ulju od 49,79\% (m/m), koji je određen metodom spoljašnjeg standarda primenom GC-FID, što je prinos od 281,31 mg/100 g droge. Komponente koje se nalaze u većem procentu od $3 \%$ su $\delta$-kadinen $8,12 \%$ (odnosno $8,07 \%(\mathrm{~m} / \mathrm{m})$ ), germakren 5,76\% (odnosno 5,73\% (m/m)), $\alpha$-bergamoten 4,14\% $(4,11 \%$ $(\mathrm{m} / \mathrm{m}))$, eugenol 3,76\% $(3,74 \%(\mathrm{~m} / \mathrm{m}), \beta$-selinen 3,58\% $(3,56 \%(\mathrm{~m} / \mathrm{m}))$ i metil-havikol 3,30\% (odnosno $3,38 \%(\mathrm{~m} / \mathrm{m})$ ).

Rezultati ispitivanja hemijskog sastava etarskog ulja Ocimum basilicum L. pokazuju da ono pripada linaloolskom hemotipu (hemotip A) koji je karakterističan za Evropsko područje (linalool 41\%, metil-havikol 22\%, Suppakul i sar., 2003). Prema literaturnim podacima, Evropski tip bosiljka sadrži etarsko ulje najboljeg kvaliteta i arome, a sastoji se od: linaloola, metil-havikola i manjeg sadržaja 1,8-cineola, $\alpha$-pinena, $\beta$-pinena, mircena, terpinolena, kamfora, $\alpha$-terpineola i eugenola (Simon i sar., 1990). 
Tabela 12. Kvalitativni i kvantitativni sastav etarskog ulja bosiljka

\begin{tabular}{|c|c|c|c|c|}
\hline Komponente & $\begin{array}{l}\mathbf{t}_{\mathrm{R}}^{\mathrm{a}} \\
(\mathrm{min}) \\
\end{array}$ & $\begin{array}{c}\text { Relativni udeo }^{\mathrm{b}} \\
(\%)\end{array}$ & $\begin{array}{l}\text { Udeo }^{c} \\
(\mathrm{~g} / 100 \mathrm{~g}) \\
\end{array}$ & $\begin{array}{l}\text { Prinos destilacije }^{\mathrm{d}} \\
(\mathrm{mg} / 100 \mathrm{~g})\end{array}$ \\
\hline Monoterpenski ugljovodonici & & 1,26 & 1,28 & 7,23 \\
\hline$\beta$-Pinen & 7,24 & 0,39 & 0,39 & 2,20 \\
\hline Mircen & 7,88 & 0,29 & 0,29 & 1,64 \\
\hline (+)-Limonen & 9,34 & 0,39 & 0,41 & 2,32 \\
\hline Trans- $\beta$-Ocimen & 10,18 & 0,19 & 0,19 & 1,07 \\
\hline Oksidovani monoterpeni & & 55,84 & 55,96 & 316,11 \\
\hline 1,8-Cineol (Eukaliptol) & 9,38 & 2,50 & 2,69 & 15,20 \\
\hline Linalool & 12,73 & 50,09 & 49,79 & 281,31 \\
\hline Kamfor & 14,03 & 0,49 & 0,48 & 2,71 \\
\hline Terpinen-4-ol & 15,48 & 0,33 & 0,33 & 1,86 \\
\hline$\alpha$-Terpineol & 16,14 & 0,35 & 0,47 & 2,60 \\
\hline Geraniol & 18,60 & 1,53 & 1,66 & 9,38 \\
\hline Bornilacetat & 19,39 & 0,55 & 0,54 & 3,05 \\
\hline \multicolumn{2}{|c|}{ Aromatični oksidovani monoterpeni } & 7,06 & 7,12 & 40,23 \\
\hline Eugenol & 22,30 & 3,76 & 3,74 & 21,13 \\
\hline Metil-havikol & 16,28 & 3,30 & 3,38 & 19,10 \\
\hline Seskviterpenski ugljovodonici & & 30,77 & 30,57 & 172,71 \\
\hline$\beta$-Kubeben & 25,53 & 0,69 & 0,69 & 3,90 \\
\hline$\beta$-Elemen & 23,15 & 1,15 & 1,14 & 6,44 \\
\hline Trans-Kariofilen & 24,05 & 0,67 & 0,66 & 3,73 \\
\hline$\alpha$-Bergamoten & 24,58 & 4,14 & 4,11 & 23,22 \\
\hline$\alpha$-Humulen & 25,21 & 1,03 & 1,02 & 5,76 \\
\hline Germakren & 26,14 & 5,76 & 5,73 & 32,37 \\
\hline Germakren D & 26,62 & 1,52 & 1,51 & 8,53 \\
\hline$\gamma$-Kadinen & 27,23 & 3,14 & 3,12 & 17,63 \\
\hline$\delta$-Kadinen & 31,35 & 8,12 & 8,07 & 45,60 \\
\hline$\alpha$-Selinen & 28,97 & 0,97 & 0,96 & 5,42 \\
\hline$\beta$-Selinen & 26,92 & 3,58 & 3,56 & 20,11 \\
\hline Oksidovani seskviterpeni & & $\mathbf{0 , 7 3}$ & $\mathbf{0 , 7 2}$ & 4,07 \\
\hline Spatulenol & 29,41 & 0,73 & 0,72 & 4,07 \\
\hline $\begin{array}{l}\text { Udeo identifikovanih } \\
\text { komponenti }\end{array}$ & & 95,66 & 95,65 & \\
\hline Ukupni prinos & & & & 540,35 \\
\hline $\begin{array}{l}{ }^{\mathrm{a}}-\text { Retenciono vreme }\left(\mathrm{t}_{\mathrm{R}}\right) \\
\mathrm{b}-\text { Rezultati GC/MS analize } \\
\mathrm{c}-\text { Rezultati GC/FID analize } \\
\mathrm{d}-\text { Prinos destilacije sračunat na }\end{array}$ & & & & \\
\hline
\end{tabular}




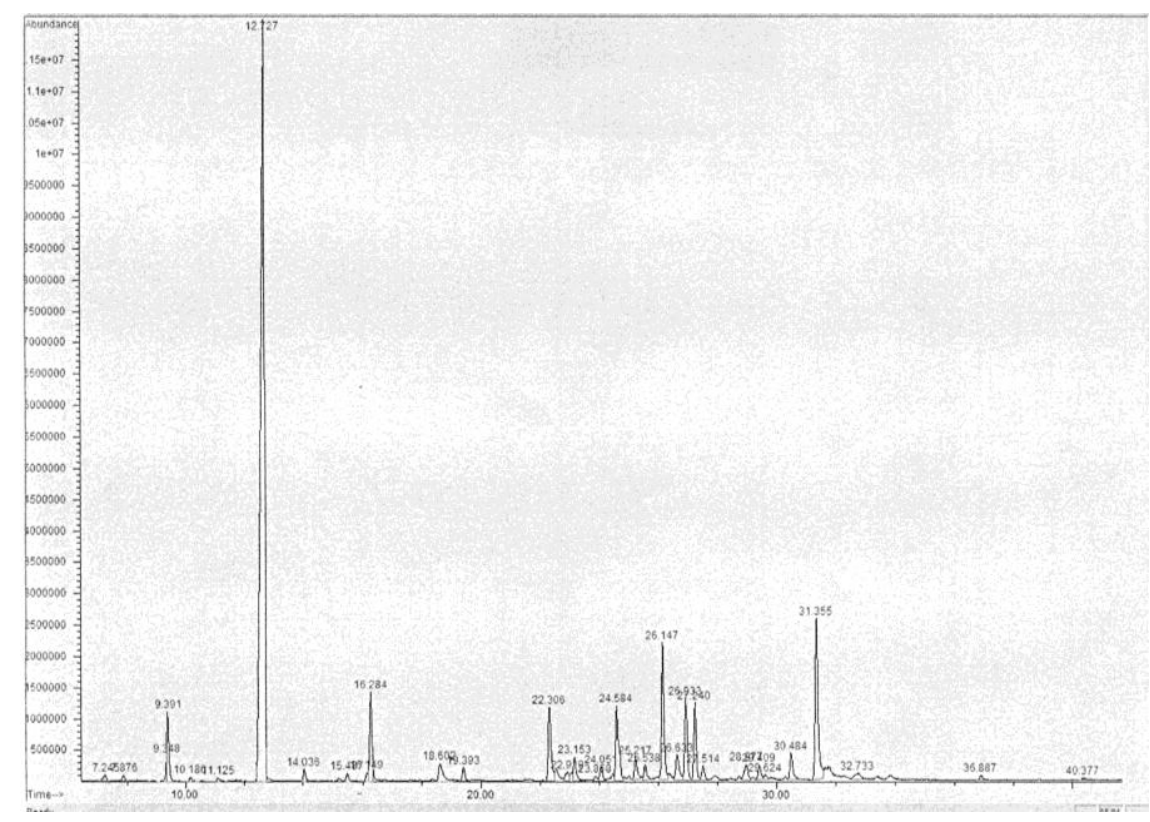

Slika 20. GC hromatogram etarskog ulja bosiljka

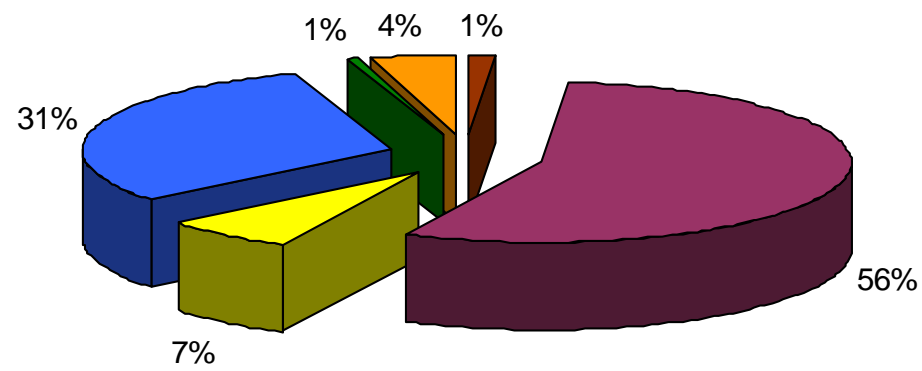

\footnotetext{
$\square$ Monoterpenski ugljovodonici $\quad \square$ Oksidovani monoterpeni $\square$ Aromatični oksidovani monoterpeni $\square$ Seskviterpenski ugljovodonici $\square$ Oksidovani seskviterpeni $\quad \square$ Neindentifikovano
}

Slika 21. Udeo dominantnih grupa jedinjenja u etarskom ulju bosiljka dobijenog hidrodestilacijom

$\mathrm{Na}$ osnovu rezultata datih u tabeli 12 može se uočiti da su relativni procenti identifikovanih jedinjenja, određenih GC/MS hromatografijom, veoma slični rezulatima dobijenih kvantifikacijom pomoću serije spoljašnjih standarda, primenom GC/FID metode i izraženi kao masa date komponente u 100 g etarskog ulja. Upoređujući rezultate dobijene primenom ove dve hromatografske tehnike može se zaključiti da se GC/MS hromatografija, koja rezultat analize daje kao relativne procente preko površina pikova, može uspešno koristiti za vrlo dobru kvantifikaciju, odnosno određivanje sadržaja lako isparljivih jedinjenja etarskih ulja i drugih aromatičnih biljaka. 


\subsection{EKSTRAKCIJA BOSILJKA SUPERKRITIČNIM UGLJENDIOKSIDOM}

Za ekstrakciju lipofilnih komponenata postupak superkritične ekstrakcije predstavlja odličnu alternativu klasičnim postupcima ekstrakcije (hidrodestilacija i ekstrakcija organskim rastvaračima). U cilju izdvajanja ekstrakta bosiljka i praćenja prinosa ekstrakcije izvršena su dva načina superkritične ekstrakcije, kao što je opisano u poglavlju 4.5. U prvom delu ispitivanja kinetike ekstrakcije dobijeni su totalni ekstrakti bosiljka. Kinetika ekstrakcije bosiljka ugljendioksidom u superkritičnom stanju praćena je na temperaturama od 40, 50 i $60^{\circ} \mathrm{C}$ i pritiscima od 100, 150, 200 i 300 bara, i pri protoku $\mathrm{CO}_{2}$ od 3,225 g/min. Vreme trajanja ekstrakcije iznosilo je 4 h. Grafički prikaz kinetike superkritične ekstrakcije dat je na slici 22, a kumulativni prinos ekstrakcije u tabeli 13 .

Tabela 13. Kumulativni prinos superkritične ekstrakcije bosiljka i prinos ekstrakcije tokom frakcionisanja

\begin{tabular}{lccc} 
Uslovi ekstrakcije & $\begin{array}{c}\text { Gustina } \mathbf{C O}_{2} \\
\left(\mathbf{k g} / \mathbf{m}^{\mathbf{3}}\right)\end{array}$ & $\begin{array}{c}\text { Prinos ekstrakcije } \\
(\mathbf{\%}, \mathbf{m} / \mathbf{m})^{\mathbf{a}}\end{array}$ & $\begin{array}{c}\text { Prinos ekstrakcije } \\
(\mathbf{\%}, \mathbf{m} / \mathbf{m})^{\mathbf{b}}\end{array}$ \\
\hline $40^{\circ} \mathrm{C}$ & & & 0,693 \\
\hline $100 \mathrm{bar}$ & 0,568 & 0,719 & 0,438 \\
$150 \mathrm{bar}$ & 0,756 & 1,238 & 0,271 \\
$200 \mathrm{bar}$ & 0,831 & 1,322 & 0,138 \\
$300 \mathrm{bar}$ & 0,929 & 1,287 & 1,008 \\
\hline $50^{\circ} \mathrm{C}$ & & 0,693 \\
\hline 100 bar & 0,378 & 0,894 & 0,348 \\
150 bar & 1,568 & 0,353 \\
200 bar & 0,659 & 1,447 & 0,657 \\
300 bar & 0,765 & 1,715 & 0,841 \\
\hline $60^{\circ} \mathrm{C}$ & 0,881 & 0,382 & 0,474 \\
100 bar & & 1,401 & 0,234 \\
200 bar & 0,294 & 1,666 & \\
300 bar & 0,563 & 1,879 &
\end{tabular}



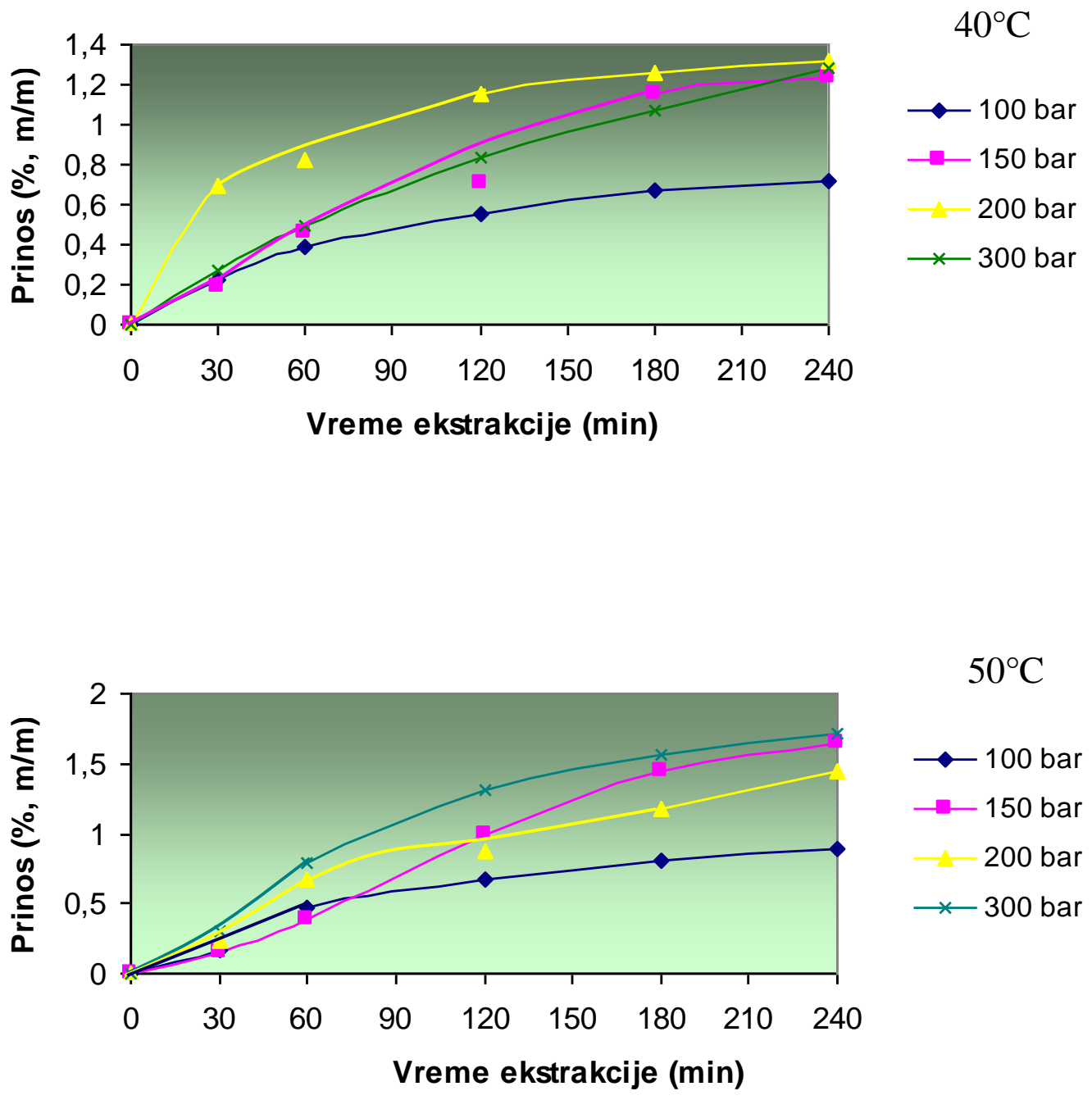

$50^{\circ} \mathrm{C}$

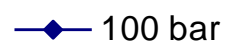

$-150 \mathrm{bar}$ 200 bar

-300 bar

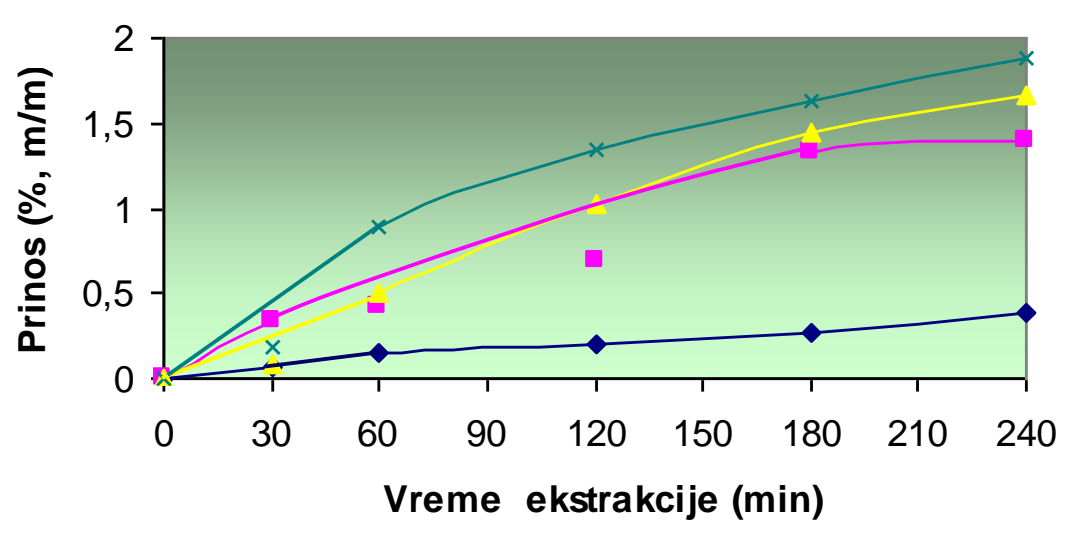

$60^{\circ} \mathrm{C}$

$\multimap 100$ bar

-150 bar 200 bar

$\leftarrow 300$ bar

Slika 22. Kinetika superkritične ekstrakcije bosiljka na temperaturama 40,50 i $60^{\circ} \mathrm{C} \mathrm{i}$ pritiscima 100, 150, 200 i 300 bara 
Iz rezultata prikazanih na slici 22 se vidi da se ekstrakcija odvija kroz dva perioda. Period brze ekstrakcije, koji se postiže za vreme do 60 minuta, gde su ekstrahovane lako rastvorne komponente u superkritičnom ugljendioksidu, nakon čega sledi period spore ekstrakcije. Može se uočiti da se pri izotermnoj ekstrakciji sa povećanjem pritiska povećava prinos ekstrakcije, jer se povećava gustina $\mathrm{CO}_{2}$, a samim tim i moć rastvaranja $\mathrm{CO}_{2}$ kao ekstragensa. $\mathrm{Na} 40^{\circ} \mathrm{C}$ sa porastom pritiska prinos ekstrakcije raste od 0,719 do $1,287 \%$, na temperaturi od $50^{\circ} \mathrm{C}$ prinos ekstrakcije raste od 0,894 do $1,715 \%$, a na $60^{\circ} \mathrm{C}$ prinos ekstrakcije se povećava porastom radnog pritiska od 0,382 do $1,879 \%$.

Sa druge strane, sa povećanjem radne temperature ekstrakcije može se uočiti da se prinos ekstrakcije takođe povećava, pri čemu je najveći prinos ekstrakcije ostvaren na temperaturi od $60^{\circ} \mathrm{C}$ i pritisku od 300 bar, i iznosi $1,879 \%$. Ovo se može objasniti povećanjem rastvorljivosti komponenata u superkritičnom fluidu sa povećanjem temperature ekstrakcije.

Iako je bosiljak predmet brojnih različitih istraživanja, u literaturi se nalazi relativno malo podataka o ekstrakciji bosiljka superkritičnim ugljendioksidom. Lachowicz i saradnici (1996) su superkritičnom ekstrakcijom bosiljka, koji je uzgajan u Australiji, dobili najveći prinos od $0,97 \%$ pri pritisku od 306 atm i temperaturi od $40^{\circ} \mathrm{C}$ u toku dvočasovne ekstrakcije. Mazutti i saradnici (2006) su ekstrakcijom O. basilicum L. pri temperaturi od $50^{\circ} \mathrm{C}$ i pritisku od 250 atm ostvarili najveći prinos ekstrakcije od 1,95\% u toku tročasovne ekstrakcije. Prinos ekstrakcije se povećava uz dodatak kosolvenata, što su u svojim radovima pokazali Menaker i saradnici (2006) i Leal i saradnici (2008). Pri ekstrakciji bosiljka superkritičnim ugljendioksidom uz dodatak 7,5\% etanola i uslovima ekstrakcije: temperatura $45^{\circ} \mathrm{C}$, pritisak 25,5 MPa i vreme ekstrakcije $1 \mathrm{~h}$, Menaker i saradnici (2006) su ostvarili najveći prinos od 0,44\%. Leal i saradnici (2008) su najveći prinos ekstrakta (2,4\%) dobili pri ekstrakciji bosiljka tečnim ugljendioksidom na temperaturi od $30^{\circ} \mathrm{C}$, pritisku od $30 \mathrm{MPa}$ uz dodatak vode kao kosolventa u koncentraciji od 20\%.

Ekstrakti bosiljka dobijeni frakcionisanjem na konstantnoj temperaturi uz sukcesivno povećanje pritiska (100, 150, 200 i 300 bar), vizuelno su se značajno razlikovali. Ekstrakti bosiljka dobijeni pri pritisku od 100 bara i temperaturi od 40,50 i $60^{\circ} \mathrm{C}$ su bili svetlo do tamno žute uljaste tečnosti, koje su imale izgled sličan etarskom ulju bosiljka. Ekstrakti dobijeni na 150, 200 i 300 bar, i temperaturama 40, 50 i $60^{\circ} \mathrm{C}$, su menjali boju od narandžaste do tamno zelene, i imali su konzistenciju viskozne paste. U ekstraktima na većim pritiscima i temperaturama se osim lako isparljivih supstanci (komponente etarskih ulja) nalaze i druge komponete visoke tačke ključanja i veće molekulske mase, kao što su masne kiseline, masna ulja, kutikularni voskovi, pigmenti, fitosteroli i dr. 

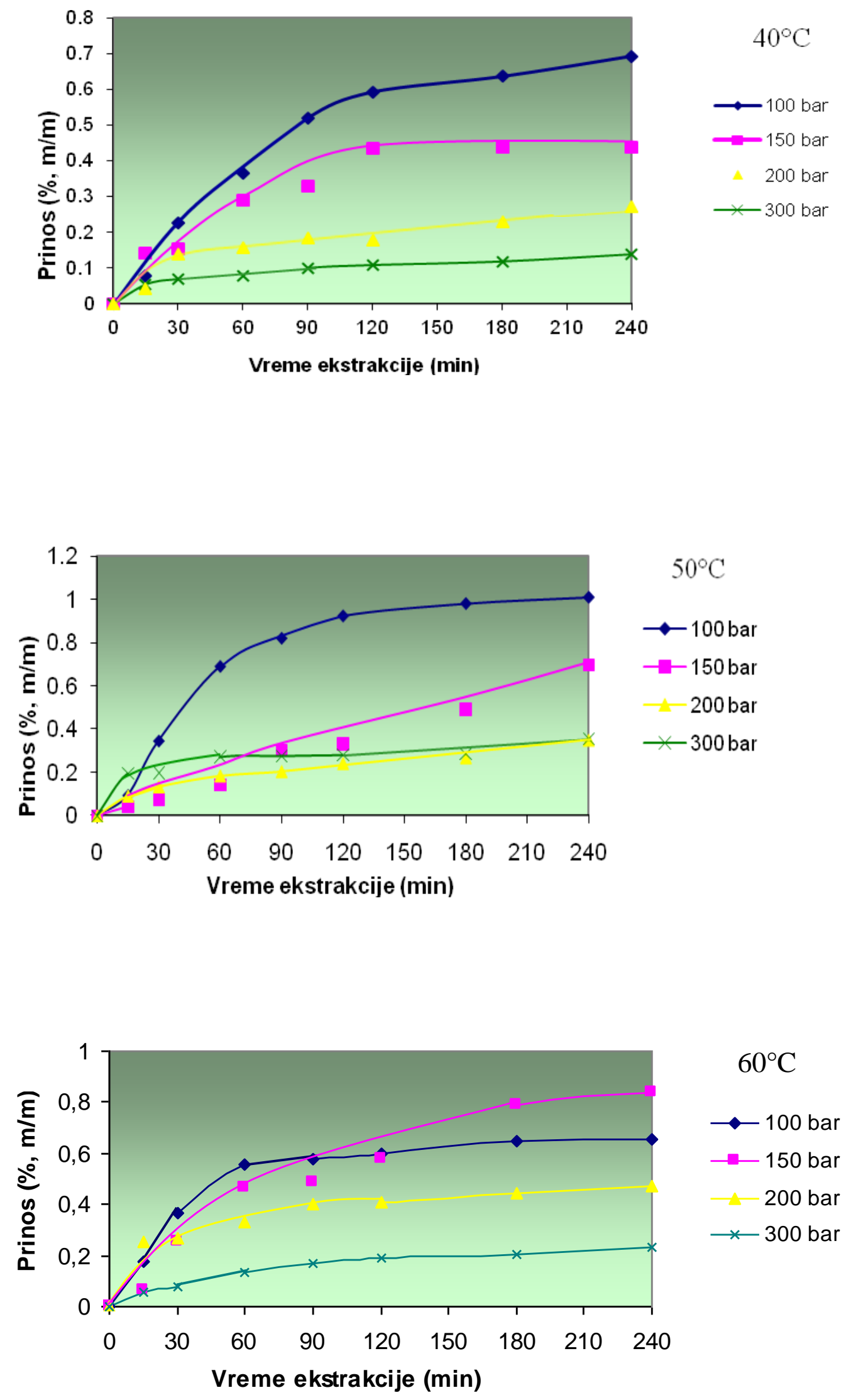

Slika 23. Kinetika superkritične ekstrakcije bosiljka tokom frakcionisanja na temperaturama 40,50 i $60^{\circ} \mathrm{C}$ i pritiscima $100,150,200$ i 300 bar 
Na osnovu dobijenih rezultata tokom frakcionisanja (tabela 13) može se uočiti da se najveći prinos tokom frakcionisanja postiže pri pritisku od 100 bara i $40^{\circ} \mathrm{C}$ i iznosi $0,693 \%$, i 100 bara i $50^{\circ} \mathrm{C}$ u iznosu od $1,008 \%$, odnosno u prvoj fazi frakcione ekstrakcije. U slučaju frakcionisanja na temperaturi od $60^{\circ} \mathrm{C}$ najveći prinos je postignut pri pritisku od 150 bara $(0,841 \%)$, nešto veći u odnosu na prvu fazu frakcionisanja (0,657\%). Povećanjem pritiska, tj. gustine, $\mathrm{i}$ iscrpljivanjem droge prinos se smanjuje (tabela 13 i slika 23). Na temperaturi od $40^{\circ} \mathrm{C}$ prinos opada od 0,693 do $0,138 \%$, na temperaturi od $50^{\circ} \mathrm{C}$ opada sa 1,008 na $0,353 \%$, dok u slučaju $\mathrm{CO}_{2}$ ekstrakcije na $60^{\circ} \mathrm{C}$ prinos od $0,657 \%$ raste do $0,841 \%$, a zatim opada do $0,234 \%$.

\subsection{GASNO HROMATOGRAFSKA ANALIZA EKSTRAKATA BOSILJKA}

\subsubsection{Soxhlet ekstrakcija}

Biljni materijal je ekstrahovan metilen-hloridom primenom ekstrakcije sa povremenim ispuštanjem ekstrakta - Soxhlet ekstrakcije (poglavlje 4.4.). Nakon odstranjivanja ekstragensa, prinos suvog ekstrakta iznosio je 1,950\% (m/m), što je oko tri puta veći prinos u odnosu na prethodno određeni sadržaj etarskog ulja u bosiljku. Soxhlet ekstrakcijom, iz ispitivanog uzorka bosiljka, osim etarskog ulja ekstrahovana su i ostala lipofilna (nepolarna) jedinjenja.

Primenom GC/MS hromatografije izvršena je kvalitativna i kvantitativna (relativni udeo (\%)), kao i kvantitativna analiza (primenom GC/FID i standardnih jedinjenja) suvog ekstrakta bosiljka. Detektovana jedinjenja i njihov sadržaj dati su u tabeli 14, a hromatogram je prikazan na slici 24.

U odnosu na hemijski sastav etarskog ulja, totalni ekstrakt dobijen metilen-hloridom se znatno razlikuje $\mathrm{u}$ pogledu broja identifikovanih jedinjenja (15 identifikovanih komponenata) i njihovog relativnog procentnog sadržaja. Najzastupljenija hemijska grupa u ovom ekstraktu su seskviterpenski ugljovodonici (18,61\%), zatim slede oksidovani monoterpeni (16,22\%), aromatični oksidovani monoterpeni (11,07\%) i oksidovani seskviterpeni (2,22\%). Sadržaj dominantne komponente linaloola je znatno manji nego u etarskom ulju bosiljka i iznosi svega 11,46\% (GC/MS) (kvantitativni sadržaj je 2,56 \% (m/m), odnosno prinos ekstrakcije je 49,92 mg/100 g droge, određen i GC/FID metodom). Sadržaj 
ostalih komponenti koje se nalaze u većem procentu je sledeći: eugenol 10,16\% (2,27\% $(\mathrm{m} / \mathrm{m})), \delta$-kadinen $8,27 \%(1,85 \%(\mathrm{~m} / \mathrm{m}))$ i $\gamma$-kadinen $4,11 \%(0,92 \%(\mathrm{~m} / \mathrm{m}))$. Takođe se uočava da je u ekstraktu u većem udelu $(23,50 \%$, odnosno $5,25 \%(\mathrm{~m} / \mathrm{m}))$ prisutna nepolarna komponenta veće molekulske mase koja se eluira pri većem retencionom vremenu $(52,90$ min), a koja nije identifikovana.

Rezultati hromatografske analize ekstrakta bosiljka dobijenog Soxhlet ekstrakcijom pokazuju da se ovim postupkom ekstrakcije, osim etarskog ulja ekstrahuju gotovo sve prisutne lipidne komponente i biljni pigmenti.

Tabela 14. Kvalitativni i kvantitativni sastav ekstrakta dobijenog Soxhlet ekstrakcijom

\begin{tabular}{|c|c|c|c|c|c|}
\hline $\mathbf{N}^{\circ}$ & Komponente & $\begin{array}{c}\mathbf{t}_{\mathbf{R}} \\
(\mathrm{min})\end{array}$ & $\begin{array}{l}\text { Relativni } \\
\text { udeo }(\%)\end{array}$ & $\begin{array}{l}\text { Sadržaj } \\
(\mathrm{g} / 100 \mathrm{~g})\end{array}$ & $\begin{array}{l}\text { Prinos ekstrakcije } \\
\text { (mg/100 g) }\end{array}$ \\
\hline 1 & 1,8-Cineol & 9,21 & 0,26 & 0,1 & 1,95 \\
\hline 2 & Linalool & 12,37 & 11,46 & 2,56 & 49,92 \\
\hline 3 & Kamfor & 13,88 & 0,52 & 0,12 & 2,34 \\
\hline 4 & $\alpha$-Terpineol & 16,01 & 2,81 & 1,49 & 29,05 \\
\hline 5 & Metil-havikol & 16,14 & 0,91 & 0,34 & 6,63 \\
\hline 6 & n.i. & 16,38 & 6,02 & 1,34 & 26,13 \\
\hline 7 & Geraniol & 18,43 & 0,64 & 0,22 & 4,29 \\
\hline 8 & Bornilacetat & 19,25 & 0,53 & 0,12 & 2,34 \\
\hline 9 & n.i. & 19,59 & 9,83 & 2,20 & 42,90 \\
\hline 10 & Eugenol & 22,18 & 10,16 & 2,27 & 44,26 \\
\hline 11 & $\beta$-Elemen & 22,80 & 2,25 & 0,50 & 9,75 \\
\hline 12 & $\alpha$-Bergamoten & 24,42 & 2,03 & 0,45 & 8,78 \\
\hline 13 & $\beta$-Kubeben & 25,39 & 0,56 & 0,13 & 2,53 \\
\hline 14 & $\gamma$-Kadinen & 27,07 & 4,11 & 0,92 & 17,94 \\
\hline 15 & n.i. & 27,34 & 0,36 & 0,08 & 1,56 \\
\hline 16 & $\alpha$-Selinen & 28,81 & 1,39 & 0,31 & 6,04 \\
\hline 17 & Spatulenol & 29,27 & 2,22 & 0,50 & 9,75 \\
\hline 18 & n.i. & 30,33 & 1,42 & 0,32 & 6,24 \\
\hline 19 & $\delta$-Kadinen & 31,18 & 8,24 & 1,85 & 36,07 \\
\hline 20 & n.i. & 31,58 & 0,61 & 0,14 & 2,73 \\
\hline 21 & n.i. & 32,55 & 3,55 & 0,79 & 15,40 \\
\hline 22 & n.i. & 33,63 & 1,43 & 0,32 & 6,24 \\
\hline 23 & n.i. & 36,42 & 1,39 & 0,31 & 6,04 \\
\hline 24 & n.i. & 43,47 & 2,42 & 0,54 & 10,53 \\
\hline 25 & n.i. & 52,90 & 23,50 & 5,25 & 102,37 \\
\hline 26 & n.i. & 58,03 & 1,38 & 0,31 & 6,04 \\
\hline \multicolumn{3}{|c|}{$\Sigma$} & 100,00 & 23,48 & 457,86 \\
\hline \multicolumn{3}{|c|}{ Ostala lipofilna jedinjenja } & & 76,52 & $1.492,14$ \\
\hline
\end{tabular}

$\mathrm{t}_{\mathrm{R}}$ - Retenciono vreme

n.i. - Neidentifikovana komponenta 


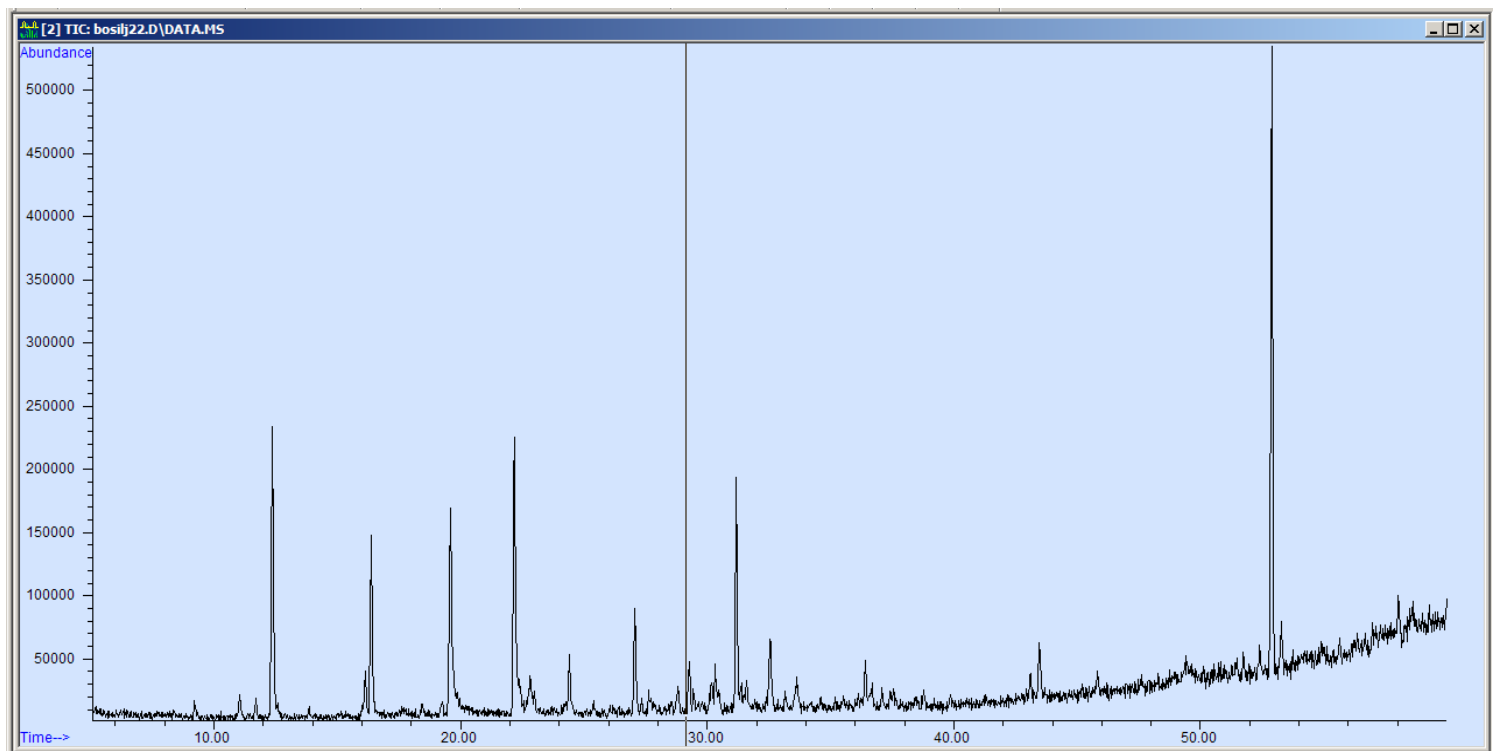

Slika 24. GC/MS hromatogram ekstrakta bosiljka dobijenog Soxhlet ekstrakcijom

\subsubsection{Superkritična ekstrakcija}

\subsubsection{Totalni (ukupni) ekstrakti}

Prinosi ekstrakcije bosiljka superkritičnim ugljendioksidom dati su u tabeli 13, a rezultati relativanog udela komponenata u dobijenim ekstraktima primenom GC/MS metode, dati su u tabeli 15 .

Komponente prisutne u ekstraktima grupisane su u četiri osnovne grupe: oksidovani monoterpeni, aromatični oksidovani monoterpeni, seskviterpenski ugljovodonici i oksidovani seskviterpeni. Udeo oksidovanih monoterpena se kretao od 25,03 do 33,4\%, aromatičnih oksidovanih monoterpena od 15,75 do $20,29 \%$, seskviterpenskih ugljovodonika od 27,68 do $38,81 \%$ i oksidovanih seskviterpena od 1,63 do $2,67 \%$.

Kvantitativni sadržaj komponenata u dobijenim $\mathrm{CO}_{2}$ ekstraktima određen je primenom GC/FID metode i metode spoljašnjeg standarda (eksperimentalni deo 4.7.), dobijeni su rezultati koji su dati u tabeli 16 .

Najveći sadržaj oksidovanih monoterpena iznosio je 18,73\% u ekstraktu bosiljka 100/40. Sadržaj oksidovanih monoterpena sa porastom pritiska (od 100 do 300 bar), tj. gustine $\mathrm{CO}_{2}$, pri konstantnoj temperaturi opada. $\mathrm{Na} 40^{\circ} \mathrm{C}$ sa $18,73 \%$ na $13,48 \%$, na $50^{\circ} \mathrm{C}$ sa $13,48 \%$ na $11,98 \%$, i na temperaturi $60^{\circ} \mathrm{C}$ sa $11,42 \%$ na $8,4 \%$. Najveći sadržaj aromatičnih oksidovanih monoterpena od 10,4\% je ostvaren u ekstraktu 100/50. I u ovom slučaju, sa 
porastom pritiska pri konstantnoj temperaturi, opada sadržaj ove grupe komponenata. Najveći sadržaj seskviterpenskih ugljovodonika od 21,44\% određen je u ekstraktu 100/50, i sa porastom pritiska pri izotermskim uslovima ovaj sadržaj se smanjuje. Oksidovani seskviterpen (spatulenol) je najveći sadržaj imao u ekstraktu 100/40 (1,27\%) i pokazuje, takođe, smanjenje sadržaja sa porastom pritiska na konstantnoj temperaturi.

U dobijenim ekstraktima bosiljka dominatne su sledeće komponente: linalool, eugenol i $\delta$-kadinen. Ostale komponente koje su imale sadržaj iznad 2\% su: $\alpha$-bergamoten, germakren D, $\gamma$-kadinen i $\beta$-selinen.

Najveći sadržaj linaloola (16,6\%) određen je u ekstraktu 100/40, ali najveća količina linaloola koja je ekstrahovana iz $100 \mathrm{~g}$ droge nije dobijena pri ovim ekstrakcionim uslovima. Najveći prinos linaloola je dobijen primenom pritiska od 200 bar na $40^{\circ} \mathrm{C}$ (uzorak 200/40), odnosno gustine $\mathrm{CO}_{2} 0,831 \mathrm{~kg} / \mathrm{m}^{3}$ i iznosi $199,75 \mathrm{mg} / 100 \mathrm{~g}$ droge (tabela 17). U grupi aromatičnih oksidovanih monoterpena najveći prinos eugenola od 123,29 mg/100 g droge je dobijen u ekstraktu 150/60, iako je najveći udeo ove komponente (9,78\%) u ekstraktu 100/50. $\delta$-Kadinen je dominatna komponenta grupe seskviterpenskih ugljovodonika sa najvećim udelom u ekstraktu bosiljka (uzorak 100/50) od 7,21\%. Najveći prinos $\delta$-kadinena, na osnovu proračuna je ipak, ostvaren u ekstraktu 150/50 (91,79 mg/100 g droge). 
Tabela 15. Relativni udeo komponenata totalnog ekstrakata dobijenih superkritičnom ekstrakcijom

\begin{tabular}{|c|c|c|c|c|c|c|c|c|c|c|c|c|}
\hline \multirow{3}{*}{ Komponente } & \multicolumn{12}{|c|}{ Relativni udeo (\%) } \\
\hline & \multicolumn{12}{|c|}{ Pritisak (bar)/temperatura $\left({ }^{\circ} \mathbf{C}\right)$} \\
\hline & $100 / 40$ & $150 / 40$ & $200 / 40$ & $300 / 40$ & $100 / 50$ & 150/50 & $200 / 50$ & $300 / 50$ & $100 / 60$ & $150 / 60$ & $200 / 60$ & $300 / 60$ \\
\hline Oksidovani monoterpeni & 31,52 & 32,86 & 33,4 & $\mathbf{3 1 , 5 7}$ & 25,03 & 27,69 & 27,10 & 27,65 & 23,77 & 25,99 & 27,10 & 30,13 \\
\hline 1,8-Cineol & 0,61 & 0,91 & 0,99 & 2,00 & 0,48 & 0,71 & 1,15 & 0,89 & 0,20 & 0,71 & 1,00 & 1,09 \\
\hline Linalool & 27,80 & 29,33 & 29,40 & 26,09 & 21,33 & 24,35 & 23,12 & 23,55 & 21,64 & 22,83 & 23,90 & 26,26 \\
\hline Kamfor & 0,39 & 0,28 & 0,34 & 0,38 & - & 0,20 & 0,31 & 0,29 & - & - & - & - \\
\hline$\alpha$-Terpineol & 1,03 & 0,92 & 1,05 & 1,50 & 2,00 & 0,98 & 1,21 & 1,42 & 1,04 & 1,11 & 1,10 & 0,66 \\
\hline Geraniol & 1,25 & 0,95 & 1,19 & 0,96 & 1,22 & 1,06 & 0,74 & 1,10 & 0,89 & 1,34 & 1,10 & 1,61 \\
\hline Bornilacetat & 0,44 & 0,47 & 0,43 & 0,64 & - & 0,39 & 0,57 & 0,40 & - & - & - & 0,51 \\
\hline $\begin{array}{c}\text { Aromatični oksidovani } \\
\text { monoterpeni }\end{array}$ & 17,14 & 15,8 & 16,68 & 17,23 & 19,62 & 16,76 & 19,07 & 14,91 & 20,29 & 19,93 & 18,90 & 15,75 \\
\hline Eugenol & 15,56 & 14,36 & 14,86 & 16,09 & 17,69 & 15,37 & 17,87 & 13,72 & 19,41 & 18,90 & 18,0 & 14,03 \\
\hline Metil-havikol & 1,58 & 1,44 & 1,82 & 1,14 & 1,93 & 1,39 & 1,20 & 1,19 & 0,88 & 1,03 & 0,90 & 1,72 \\
\hline $\begin{array}{c}\text { Seskviterpenski } \\
\text { ugljovodonici }\end{array}$ & 33,10 & $\mathbf{3 4 , 3 7}$ & 32,24 & 34,81 & 38,81 & 35,56 & 34,26 & 27,68 & 35,71 & 32,15 & 35,6 & 33,98 \\
\hline$\beta$-Kubeben & 0,58 & 0,94 & 0,74 & 0,86 & 0,98 & 0,73 & 0,88 & 0,96 & 0,75 & 0,61 & 0,90 & 0,60 \\
\hline$\beta$-Elemen & 0,99 & 1,03 & 0,85 & 1,16 & 1,38 & 0,82 & 1,32 & 0,66 & 1,06 & 0,99 & 1,00 & 1,58 \\
\hline Trans-Kariofilen & 0,74 & 0,75 & 0,39 & 0,61 & 0,81 & 0,69 & - & 0,52 & 0,82 & 0,58 & 0,7 & 0,56 \\
\hline$\alpha$-Bergamoten & 4,26 & 5,56 & 5,23 & 5,57 & 5,24 & 5,23 & 4,12 & 4,14 & 4,19 & 5,19 & 5,0 & 4,67 \\
\hline$\alpha$-Humulen & 1,11 & 1,29 & 1,11 & 1,20 & 1,25 & 1,05 & 1,31 & 1,07 & 1,40 & 0,96 & 1,0 & 0,73 \\
\hline Germakren D & 5,30 & 4,81 & 5,00 & 5,63 & 5,29 & 4,42 & 4,52 & 4,30 & 4,89 & 2,54 & 4,7 & 5,47 \\
\hline$\gamma$-Kadinen & 4,55 & 4,54 & 4,13 & 4,31 & 4,83 & 4,83 & 4,58 & 3,36 & 5,49 & 4,87 & 4,3 & 4,26 \\
\hline$\delta$-Kadinen & 11,64 & 11,37 & 10,72 & 10,67 & 13,05 & 12,69 & 12,29 & 9,16 & 14,03 & 13,28 & 12,4 & 12,02 \\
\hline$\alpha$-Selinen & 0,99 & 1,45 & 1,32 & 1,29 & 1,88 & 1,84 & 1,36 & 0,70 & - & 1,39 & 1,6 & 1,13 \\
\hline$\beta$-Selinen & 2,94 & 2,63 & 2,75 & 3,51 & 3,35 & 2,74 & 3,21 & 2,14 & 3,08 & 1,74 & 3,00 & 2,96 \\
\hline$\gamma$-Elemen & - & - & - & - & 0,75 & 0,52 & 0,67 & 0,67 & - & - & 1,00 & - \\
\hline Oksidovani seskviterpeni & 2,12 & 2,13 & 2,21 & 2,01 & 2,26 & 2,67 & 1,92 & 1,67 & 2,59 & $\mathbf{2 , 7 0}$ & 2,30 & 1,63 \\
\hline Spatulenol & 2,12 & 2,13 & 2,21 & 2,01 & 2,26 & 2,67 & 1,92 & 1,67 & 2,59 & 2,70 & 2,30 & 1,63 \\
\hline Ukupno & 83,88 & 85,16 & 84,53 & 85,62 & 85,72 & 83,29 & 82,35 & 71,91 & 82,36 & 80,77 & 83,9 & 81,49 \\
\hline
\end{tabular}


Tabela 16. Kvantitativna analiza totalnih ekstrakata bosiljka

\begin{tabular}{|c|c|c|c|c|c|c|c|c|c|c|c|c|}
\hline \multirow{3}{*}{ Komponente } & \multicolumn{12}{|c|}{ Sadržaj komponente $(\%, \mathrm{~g} / 100$ g ekstrakta) } \\
\hline & \multicolumn{12}{|c|}{ Pritisak (bar)/temperatura $\left({ }^{\circ} \mathbf{C}\right)$} \\
\hline & $100 / 40$ & $150 / 40$ & $200 / 40$ & $300 / 40$ & $100 / 50$ & $150 / 50$ & $200 / 50$ & $300 / 50$ & $100 / 60$ & $150 / 60$ & $200 / 60$ & $300 / 60$ \\
\hline Oksidovani monoterpeni & 18,73 & 14,98 & 17,12 & 13,48 & 13,48 & 13,62 & 11,75 & 11,98 & 11,42 & 12,11 & 11,10 & $\mathbf{8 , 4 0}$ \\
\hline 1,8-Cineol & 0,23 & 0,35 & 0,44 & 1,10 & 0,25 & 0,29 & 0,68 & 0,45 & 0,10 & 0,33 & 0,47 & 0,28 \\
\hline Linalool & 16,6 & 13,23 & 15,11 & 10,72 & 11,79 & 11,87 & 9,58 & 10,14 & 10,00 & 10,63 & 9,66 & 6,99 \\
\hline Kamfor & 0,23 & 0,13 & 0,17 & 0,16 & - & 0,10 & 0,13 & 0,12 & - & - & - & - \\
\hline$\alpha$-Terpineol & 0,60 & 0,47 & 0,51 & 0,8 & 0,79 & 0,53 & 0,69 & 0,54 & 0,69 & 0,62 & 0,53 & 0,28 \\
\hline Geraniol & 0,81 & 0,59 & 0,67 & 0,44 & 0,65 & 0,64 & 0,43 & 0,56 & 0,63 & 0,53 & 0,44 & 0,71 \\
\hline Bornilacetat & 0,26 & 0,21 & 0,22 & 0,26 & - & 0,19 & 0,24 & 0,17 & - & - & - & 0,14 \\
\hline $\begin{array}{c}\text { Aromatični oksidovani } \\
\text { monoterpeni }\end{array}$ & 10,16 & 7,21 & $\mathbf{8 , 5 0}$ & 7,27 & 10,40 & 8,62 & 7,92 & 6,51 & $\mathbf{9 , 4 3}$ & $\mathbf{9 , 4 2}$ & $\mathbf{7 , 8 2}$ & 4,16 \\
\hline Eugenol & 9,29 & 6,48 & 7,64 & 6,61 & 9,78 & 7,97 & 7,40 & 5,91 & 8,97 & 8,80 & 7,28 & 3,74 \\
\hline Metil-havikol & 0,87 & 0,73 & 0,86 & 0,66 & 0,62 & 0,65 & 0,52 & 0,6 & 0,46 & 0,62 & 0,54 & 0,42 \\
\hline Seskviterpenski ugljovodonici & 19,76 & $\mathbf{1 5 , 5 8}$ & 16,57 & 14,29 & 21,44 & 17,34 & 14,19 & 11,9 & 16,51 & 14,97 & 14,37 & $\mathbf{9 , 0 4}$ \\
\hline$\beta-$ Kubeben & 0,35 & 0,42 & 0,38 & 0,35 & 0,54 & 0,36 & 0,36 & 0,41 & 0,35 & 0,28 & 0,36 & 0,16 \\
\hline$\beta$-Elemen & 0,59 & 0,46 & 0,44 & 0,48 & 0,76 & 0,40 & 0,55 & 0,28 & 0,49 & 0,46 & 0,40 & 0,42 \\
\hline Trans-Kariofilen & 0,44 & 0,34 & 0,20 & 0,25 & 0,45 & 0,34 & - & 0,22 & 0,38 & 0,27 & 0,28 & 0,15 \\
\hline$\alpha$-Bergamoten & 2,54 & 2,59 & 2,69 & 2,29 & 2,90 & 2,55 & 1,71 & 1,78 & 1,94 & 2,42 & 2,02 & 1,24 \\
\hline$\alpha$-Humulen & 0,66 & 0,58 & 0,57 & 0,49 & 0,69 & 0,51 & 0,54 & 0,46 & 0,65 & 0,45 & 0,40 & 0,19 \\
\hline Germakren D & 3,16 & 2,17 & 2,57 & 2,31 & 2,92 & 2,15 & 1,87 & 1,85 & 2,26 & 1,18 & 1,90 & 1,46 \\
\hline$\gamma$-Kadinen & 2,72 & 2,05 & 2,12 & 1,77 & 2,67 & 2,35 & 1,90 & 1,45 & 2,54 & 2,27 & 1,74 & 1,13 \\
\hline$\delta$-Kadinen & 6,95 & 5,13 & 5,51 & 4,38 & 7,21 & 6,19 & 5,09 & 3,94 & 6,48 & 6,18 & 5,01 & 3,20 \\
\hline$\alpha$-Selinen & 0,59 & 0,65 & 0,68 & 0,53 & 1,04 & 0,90 & 0,56 & 0,30 & 0 & 0,65 & 0,65 & 0,30 \\
\hline$\beta$-Selinen & 1,76 & 1,19 & 1,41 & 1,44 & 1,85 & 1,34 & 1,33 & 0,92 & 1,42 & 0,81 & 1,21 & 0,79 \\
\hline$\gamma$-Elemen & - & - & - & - & 0,41 & 0,25 & 0,28 & 0,29 & - & - & 0,40 & - \\
\hline Oksidovani seskviterpeni & 1,27 & 0,96 & 1,14 & $\mathbf{0 , 8 3}$ & 1,25 & 1,30 & $\mathbf{0 , 8 0}$ & 0,72 & 1,20 & 1,26 & 0,93 & $\mathbf{0 , 4 3}$ \\
\hline Spatulenol & 1,27 & 0,96 & 1,14 & 0,83 & 1,25 & 1,30 & 0,80 & 0,72 & 1,20 & 1,26 & 0,93 & 0,43 \\
\hline Ukupno & 49,92 & 38,73 & 43,33 & 35,87 & 46,57 & 35,7 & 34,66 & 31,11 & 38,56 & 37,76 & 34,22 & 22,03 \\
\hline Neidentifikovane komponente & 50,08 & 61,27 & 56,67 & 64,13 & 53,43 & 64,3 & 65,34 & 68,89 & 61,44 & 62,24 & 65,78 & 77,97 \\
\hline
\end{tabular}


Tabela 17. Prinos ekstrakcije komponenata bosiljka (mg/100 g droge)

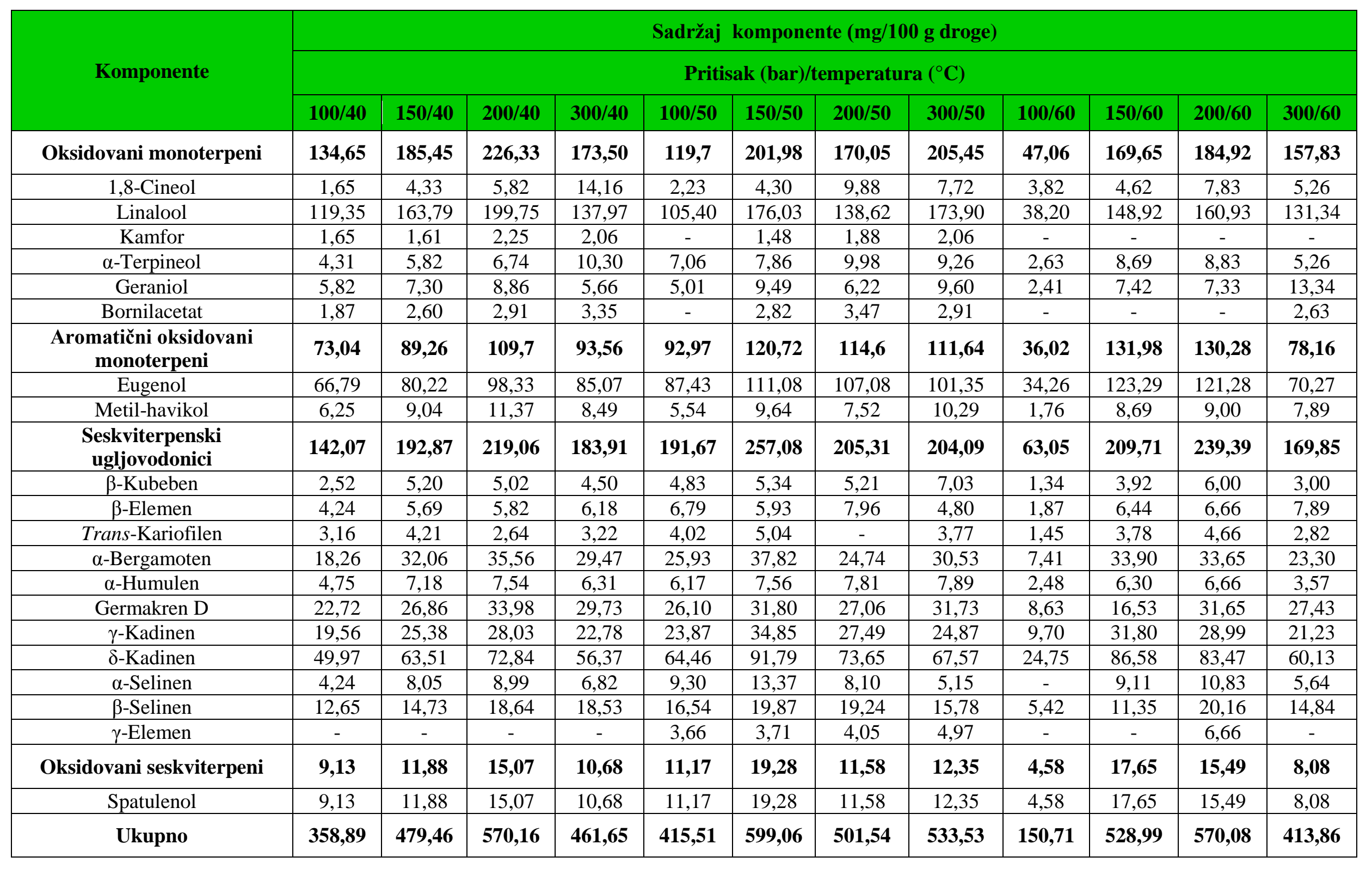


Na slici 25 je dat prikaz prinosa dominatnih komponenata u zavisnosti od ekstrakcionih uslova, odnosno gustine superkritičnog $\mathrm{CO}_{2}$.

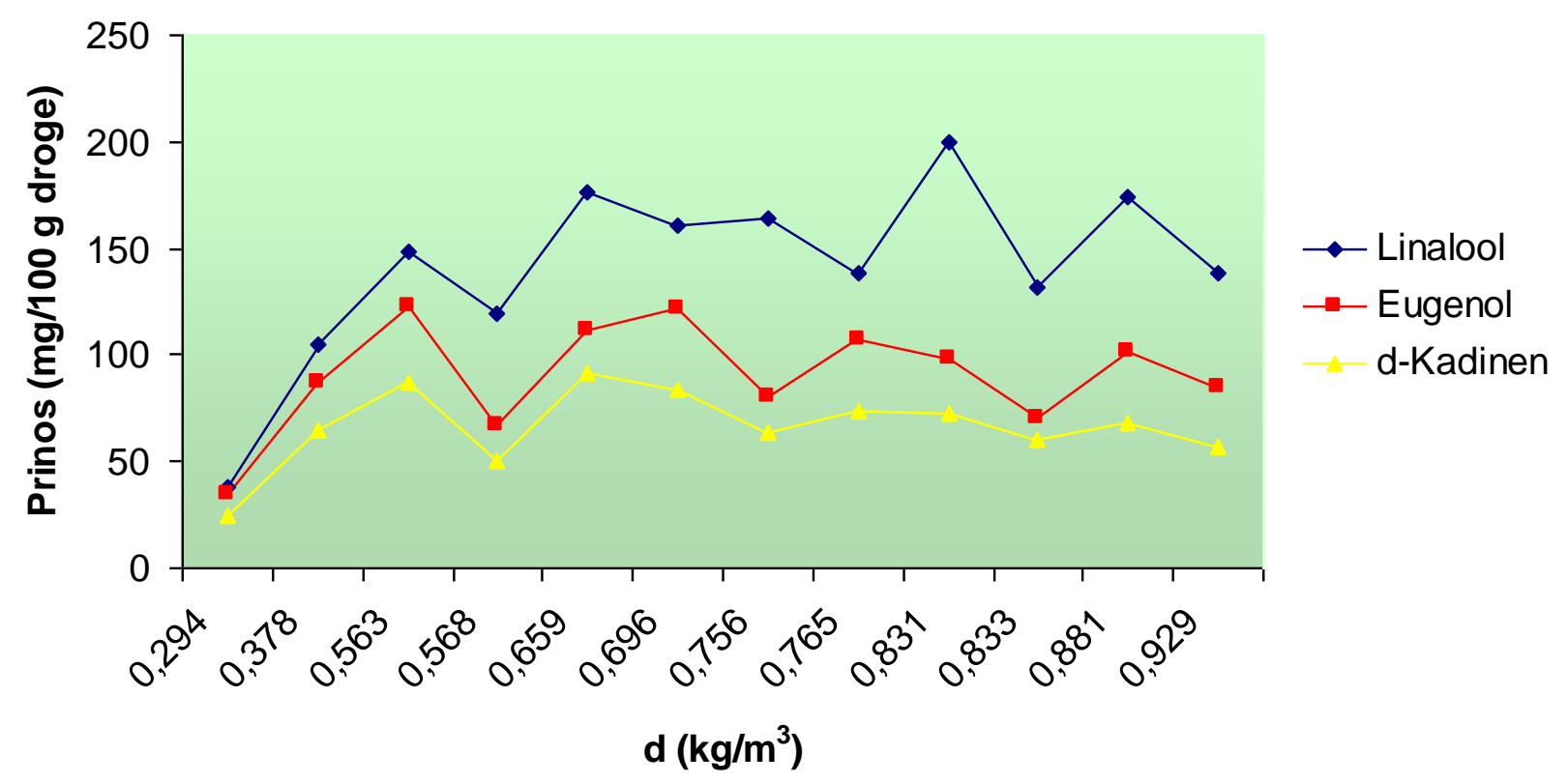

Slika 25. Prinos ekstrakcije dominantnih komponenata u zavisnosti od gustine ugljendioksida (d).

Najveći prinos linaloola je ostvaren pri gustini $\mathrm{CO}_{2}$ od $0,831 \mathrm{~kg} / \mathrm{m}^{3}$, eugenola pri gustini $\mathrm{CO}_{2}$ od $0,563 \mathrm{~kg} / \mathrm{m}^{3}$, a $\delta$-kadinena pri gustini $\mathrm{CO}_{2}$ od $0,659 \mathrm{~kg} / \mathrm{m}^{3}$. Ova tri dominantna jedinjenja pokazuju slične osobine rastvaranja u odnosu na gustinu superkritičnog $\mathrm{CO}_{2}$.

Najveći relativni sadržaj $\gamma$-kadinena $(2,72 \%)$ i germakrena D $(3,16 \%)$ je ostvaren u ekstraktu 100/40, dok je sadržaj $\alpha$-bergamotena $(2,90 \%)$ i $\beta$-selinena (1,85\%) imao najveću vrednost u ekstraktu bosiljka 100/50. Prinosi ekstrakcije $\gamma$-kadinena $(34,85 \mathrm{mg} / 100 \mathrm{~g})$ i $\alpha$-bergamotena $(37,82$ mg/100 g) su bili najveći u ekstraktu 150/50, germakrena D (33,98 mg/100 g) u ekstraktu 200/40, a $\beta$-selinena $(20,16 \mathrm{mg} / 100 \mathrm{~g})$ u ekstraktu 200/60.

Diaz - Maroto i saradnici (2002) su primenom superkritične ekstrakcije $\left(120 \mathrm{bar}, 40^{\circ} \mathrm{C}\right) \mathrm{u}$ ekstraktima bosiljka kao dominatne komponente detektovali linalool (30,73\%) i eugenol (21,80\%). Superkritičnom ekstrakcijom O. basilicum L. Mazutti i saradnici (2006) su u dobijenim ekstraktima odredili dominatne komponente: linalool (47,3\%), estragol (25,4\%) i 1,8-cineol (4,2\%), čije se sadržaj u ekstraktima menjao sa variranjem uslova ekstrakcije, odnosno variranjem gustine $\mathrm{CO}_{2}$. Lachowicz i saradnici su u svom radu još 1996. god. pokazali da se etarsko ulje bosiljka $(O$. basilicum L.) dobijeno hidrodestilacijom, kvalitativno i kvantitativno razlikuje od $\mathrm{CO}_{2}$ ekstrakta. $\mathrm{Na}$ osnovu prethodnih i naših istraživanja može se zaključiti da ekstrakti bosiljka dobijeni superkritičnom ekstrakcijom sadrže visoko vredne komponente, gde se variranjm uslova ekstrakcije 
postiže odgovarajući odnos najznačajnijih terpenskih grupa i time omogućava kreiranje novih prirodnih proizvoda prema željenoj nameni.

\subsubsection{Ekstrakti dobijeni sukcesivnom (frakcionom) ekstrakcijom}

Prinosi ekstrakcije bosiljka dobijeni sukcesivnom superkritičnom ekstrakcijom (eksperimentalni deo 4.5.), tj. frakcionisanjem lipofilnih komponenata, dati su u tabeli 13, a kvalitativni sastav dobijenih ekstrakata je dat u tabeli 18.

Procenat detektovanih komponenata u ekstraktima se kreće od 88,11\% do 11,39\%, odnosno procenat neidentifikovanih komponenata od $11,89 \%$ do $80,61 \%$. Evidentno je da se tokom frakcionisanja lipofilnih jedinjenja procenat identifikovanih komponenata smanjuje sa povećanjem pritiska pri konstantnoj temperaturi sa iscrpljivanjem droge. $\mathrm{Na}$ osnovu toga može se zaključiti da se u prvom stupnju procesa frakcionisanja dobija ekstrakt (frakcija) koja sadrži uglavnom komponente etarskog ulja bosiljka. U narednim frakcijama se povećava udeo tvz. koekstrahovanih supstanci, koje su lipofilne, ali nisu isparljive, tako da nisu prisutne u EU dobivenom destilacijom vodenom parom. $\mathrm{Na} 40^{\circ} \mathrm{C}$ sa povećanjem pritiska od 100 do 300 bara procenat identifikovanih komponenti opada sa $88,11 \%$ na $41,69 \%$, na $50^{\circ} \mathrm{C}$ povećanjem pritiska procenat identifikovanih komponenata takođe opada sa $82,2 \%$ na $72,05 \%$, a na temperaturi $60^{\circ} \mathrm{C}$ taj procenat opada od $83,01 \%$ na samo 11,39\%. Udeo isparljivih detektovanih komponenata u odnosu na ostale neidentifikovane komponenate se tokom frakcionisanja menja sa odnosa 1,25:1 na odnos 1:25. Na osnovu ovih rezultata može se zaključiti da se sa povećenjem pritiska, odnosno gustine ekstragensa, pri konstantnoj temperaturi, smanjuje udeo lako isparljivih nepolarnih komponenata (komponente etarskog ulja), a povećava udeo komponenata veće molekulske mase (voskovi, masna ulja, fitosteroli i sl.) koji se ekstrahuju na višim pritiscima, pa se time menja kvalitet ekstrakta u toku ekstrakcije (Filip i sar., 2013). Reverchon i de Marco (2006) su za superkritičnu ekstrakciju etarskog ulja iz biljnih sirovina predložili pritisak od 90 do 100 bara i temperaturu u opsegu od 40 do $50^{\circ} \mathrm{C}$.

Kvantitativna analiza komponenata u izdvojenim ekstraktima izvršena je pomoću GC/FID metode, a rezultati su dati u tabeli 19. I na osnovu ovih rezultata se može uočiti da se sadržaj identifikovanih komponenata smanjuje (od 55,26 do 3,86 g/100 g ekstrakta) sa povećanjem pritiska pri konstantnoj temperaturi, a da se sadržaj neidentifikovanih komponenata povećava (od 44,74 do 96,14 g/100 g ekstrakta). 
Tabela 18. Relativni udeo komponenata ekstrakata dobijenih frakcionisanjem lipofilnih komponenata

\begin{tabular}{|c|c|c|c|c|c|c|c|c|c|c|c|c|}
\hline \multirow{3}{*}{ Komponente } & \multicolumn{12}{|c|}{ Relativni udeo (\%) } \\
\hline & \multicolumn{12}{|c|}{ Pritisak (bar)/temperatura $\left({ }^{\circ} \mathbf{C}\right)$} \\
\hline & $100 / 40$ & $150 / 40$ & $200 / 40$ & $300 / 40$ & 100/50 & 150/50 & $200 / 50$ & $300 / 50$ & $100 / 60$ & $150 / 60$ & $200 / 60$ & $300 / 60$ \\
\hline Oksidovani monoterpeni & 36,42 & 16,88 & 8,93 & 8,71 & 30,12 & 17,58 & 10,14 & 7,25 & 25,26 & 17,18 & 7,19 & 3,38 \\
\hline 1,8-Cineol & 0,55 & 0,82 & - & - & 0,38 & - & - & - & 0,22 & - & - & - \\
\hline Linalool & 32,68 & 13,93 & 7,93 & 8,26 & 26,84 & 15,91 & 9,00 & 5,29 & 22,43 & 14,81 & 5,25 & 2,64 \\
\hline Kamfor & 0,36 & - & - & - & 0,23 & - & - & - & 0,28 & - & - & - \\
\hline$\alpha$-Terpineol & 1,05 & 1,00 & 0,42 & - & 0,99 & 0,70 & 0,30 & 0,71 & 0,84 & 0,85 & 0,41 & - \\
\hline Geraniol & 1,39 & 1,13 & 0,58 & 0,45 & 1,22 & 0,97 & 0,84 & 1,25 & 1,13 & 1,04 & 1,53 & 0,74 \\
\hline Bornilacetat & 0,39 & - & - & - & 0,46 & - & - & - & 0,36 & 0,48 & - & - \\
\hline Aromatični oksidovani monoterpeni & 16,24 & 17,14 & 11,26 & 9,81 & 16,59 & 18,42 & 17,09 & 18,28 & 19,05 & 16,68 & 17,80 & 3,10 \\
\hline Eugenol & 14,15 & 16,77 & 11,26 & 9,81 & 15,07 & 17,75 & 17,09 & 18,28 & 17,89 & 16,11 & 17,80 & 3,10 \\
\hline Metil-havikol & 2,09 & 0,37 & - & - & 1,52 & 0,67 & - & - & 1,16 & 0,57 & - & - \\
\hline Seskviterpenski ugljovodonici & 33,57 & 38,26 & 13,31 & 21,25 & 33,56 & 36,97 & 43,55 & 43,21 & 36,59 & 39,16 & 41,68 & 4,29 \\
\hline$\beta$-Kubeben & 0,96 & 0,84 & 0,53 & - & 0,68 & 0,88 & 1,79 & 1,06 & 1,04 & 0,89 & 1,12 & - \\
\hline$\beta$-Elemen & 1,03 & 1,47 & - & - & 1,02 & 1,05 & 2,14 & 0,98 & 1,05 & 0,83 & 1,57 & - \\
\hline Trans-Kariofilen & 0,76 & 1,05 & - & - & 0,62 & 0,89 & - & - & 0,66 & 0,81 & - & - \\
\hline$\delta$-Kadinen & 9,90 & 14,22 & - & 12,00 & 11,54 & 15,43 & 16,49 & 18,43 & 12,54 & 15,99 & 16,75 & 2,21 \\
\hline$\alpha$-Selinen & 1,06 & 1,06 & 0,74 & - & 0,98 & 0,78 & 1,39 & 2,77 & 1,05 & 1,19 & 2,29 & - \\
\hline$\beta$-Selinen & 2,79 & 2,25 & 3,57 & 1,25 & 2,81 & 2,42 & 2,99 & 2,99 & 3,18 & 2,84 & 3,08 & 0,22 \\
\hline$\gamma$-Elemen & 0,77 & - & 1,38 & - & 0,40 & - & - & - & 0,60 & - & - & - \\
\hline Oksidovani seskviterpeni & 1,52 & 3,09 & 1,67 & 1,92 & 1,93 & 2,96 & 3,06 & 3,31 & 2,11 & 2,76 & 2,80 & 0,62 \\
\hline Spatulenol & 1,52 & 3,09 & 1,67 & 1,92 & 1,93 & 2,96 & 3,06 & 3,31 & 2,11 & 2,76 & 2,80 & 0,62 \\
\hline Ukupno & 88,11 & 75,37 & 35,17 & 41,69 & 82,2 & 75,93 & 73,84 & 72,05 & 83,01 & 75,78 & 69,47 & 11,39 \\
\hline Neidentifikovane komponente & 11,89 & 24,63 & 64,83 & 50,31 & 17,8 & 24,07 & 26,16 & 27,95 & 16,99 & 24,22 & 30,53 & 80,61 \\
\hline
\end{tabular}


Tabela 19. Rezultati kvantitativne analize ekstrakata bosiljka dobijenih frakcionisanjem

\begin{tabular}{|c|c|c|c|c|c|c|c|c|c|c|c|c|}
\hline \multirow{3}{*}{ Komponente } & \multicolumn{12}{|c|}{ Sadržaj komponente $(\%, \mathrm{~g} / 100 \mathrm{~g}$ ekstrakta) } \\
\hline & \multicolumn{12}{|c|}{ Pritisak (bar)/temperatura $\left({ }^{\circ} \mathbf{C}\right)$} \\
\hline & $100 / 40$ & $150 / 40$ & 200/40 & $300 / 40$ & $100 / 50$ & 150/50 & $200 / 50$ & $300 / 50$ & 100/60 & 150/60 & 200/60 & $300 / 60$ \\
\hline Oksidovani monoterpeni & 22,94 & 4,69 & 1,61 & $\mathbf{0 , 9 1}$ & 18,77 & 5,41 & 3,37 & 1,62 & 16,03 & 6,02 & 2,56 & 1,56 \\
\hline 1,8-Cineol & 0,30 & 0,47 & - & - & 0,28 & - & - & - & 0,1 & - & - & - \\
\hline Linalool & 20,71 & 3,36 & 1,2 & 0,74 & 16,57 & 4,74 & 2,89 & 1,04 & 14,15 & 5,14 & 2,04 & 1,22 \\
\hline Kamfor & 0,23 & - & - & - & 0,14 & - & - & - & 0,18 & - & - & - \\
\hline$\alpha$-Terpineol & 0,64 & 0,56 & 0,16 & - & 0,67 & 0,33 & 0,14 & 0,23 & 0,59 & 0,34 & 0,15 & - \\
\hline Geraniol & 0,81 & 0,30 & 0,25 & 0,17 & 0,83 & 0,34 & 0,34 & 0,35 & 0,78 & 0,37 & 0,37 & 0,34 \\
\hline Bornilacetat & 0,25 & - & - & - & 0,28 & - & - & - & 0,23 & 0,17 & - & - \\
\hline Aromatični oksidovani monoterpeni & 10,09 & 4,22 & 1,7 & $\mathbf{0 , 8 7}$ & 10,16 & 5,49 & 5,49 & 3,59 & 12,02 & 5,79 & 6,92 & 1,43 \\
\hline Eugenol & 8,97 & 4,05 & 1,70 & 0,87 & 9,30 & 5,29 & 5,49 & 3,59 & 11,29 & 5,59 & 6,92 & 1,43 \\
\hline Metil-havikol & 1,12 & 0,17 & - & - & 0,86 & 0,20 & - & - & 0,73 & 0,20 & - & - \\
\hline Seskviterpenski ugljovodonici & 21,27 & $\mathbf{9 , 2 2}$ & 2,01 & 1,91 & 20,71 & 11,01 & 13,96 & 8,49 & 23,08 & 13,59 & 16,21 & 1,98 \\
\hline$\beta$-Kubeben & 0,61 & 0,20 & 0,08 & - & 0,42 & 0,26 & 0,57 & 0,21 & 0,66 & 0,31 & 0,44 & - \\
\hline$\beta$-Elemen & 0,65 & 0,35 & - & - & 0,63 & 0,31 & 0,67 & 0,19 & 0,66 & 0,29 & 0,61 & - \\
\hline Trans-Kariofilen & 0,48 & 0,25 & - & - & 0,38 & 0,27 & - & - & 0,42 & 0,28 & - & - \\
\hline$\alpha$-Bergamoten & 3,28 & 1,49 & 0,59 & 0,27 & 3,21 & 1,65 & 1,84 & 0,99 & 3,50 & 1,70 & 2,01 & 0,40 \\
\hline$\alpha$-Humulen & 0,87 & 0,26 & 0,05 & - & 0,56 & 0,30 & 0,50 & 0,18 & 0,52 & 0,47 & 0,47 & - \\
\hline Germakren D & 3,59 & 1,07 & 0,40 & 0,18 & 3,07 & 1,32 & 1,73 & 0,93 & 3,38 & 1,57 & 1,85 & 0,28 \\
\hline$\gamma$-Kadinen & 2,59 & 1,37 & 0,03 & 0,27 & 2,73 & 1,35 & 1,94 & 1,24 & 2,99 & 2,02 & 2,23 & 0,18 \\
\hline$\delta$-Kadinen & 6,27 & 3,43 & - & 1,08 & 7,12 & 4,60 & 5,30 & 3,62 & 7,91 & 5,55 & 6,51 & 1,02 \\
\hline$\alpha$-Selinen & 0,67 & 0,26 & 0,11 & - & 0,61 & 0,23 & 0,45 & 0,54 & 0,66 & 0,41 & 0,89 & - \\
\hline$\beta$-Selinen & 1,77 & 0,54 & 0,54 & 0,11 & 1,73 & 0,72 & 0,96 & 0,59 & 2,00 & 0,99 & 1,20 & 0,10 \\
\hline$\gamma$-Elemen & 0,49 & - & 0,21 & - & 0.25 & - & - & - & 0,38 & - & - & - \\
\hline Oksidovani seskviterpeni & 0,96 & $\mathbf{0 , 7 4}$ & 0,25 & $\mathbf{0 , 1 7}$ & 1,19 & $\mathbf{0 , 8 8}$ & $\mathbf{0 , 9 8}$ & $\mathbf{0 , 6 5}$ & 1,33 & 0,96 & 1,09 & $\mathbf{0 , 2 9}$ \\
\hline Spatulenol & 0,96 & 0,74 & 0,25 & 0,17 & 1,19 & 0,88 & 0,98 & 0,65 & 1,33 & 0,96 & 1,09 & 0,29 \\
\hline Ukupno & 55,26 & 18,87 & $\mathbf{5 , 5 7}$ & 3,86 & $\mathbf{5 0 , 8 3}$ & 22,79 & 23,8 & 14,35 & 52,46 & 26,36 & 26,78 & 5,26 \\
\hline Neidentifikovane komponente & 44,74 & 81,13 & 94,43 & 96,14 & 49,17 & 77,21 & 76,2 & 85,65 & 47,54 & 73,64 & 73,22 & 94,74 \\
\hline
\end{tabular}


$\mathrm{Na}$ osnovu dobijenih rezultata (tabela 19) ekstrakt bosiljka 100/40 je imao najviše oksidovanih monoterpena (22,94\%), dok je ekstrakt bosiljka 100/60 najviše imao seskviterpenskih ugljovodonika (23,08\%). Uočljivo je da se sadržaj svih grupa komponenata sa povećanjem pritiska pri konstantnoj temperaturi smanjuje sa iscrpljivanjem droge (slika 26).

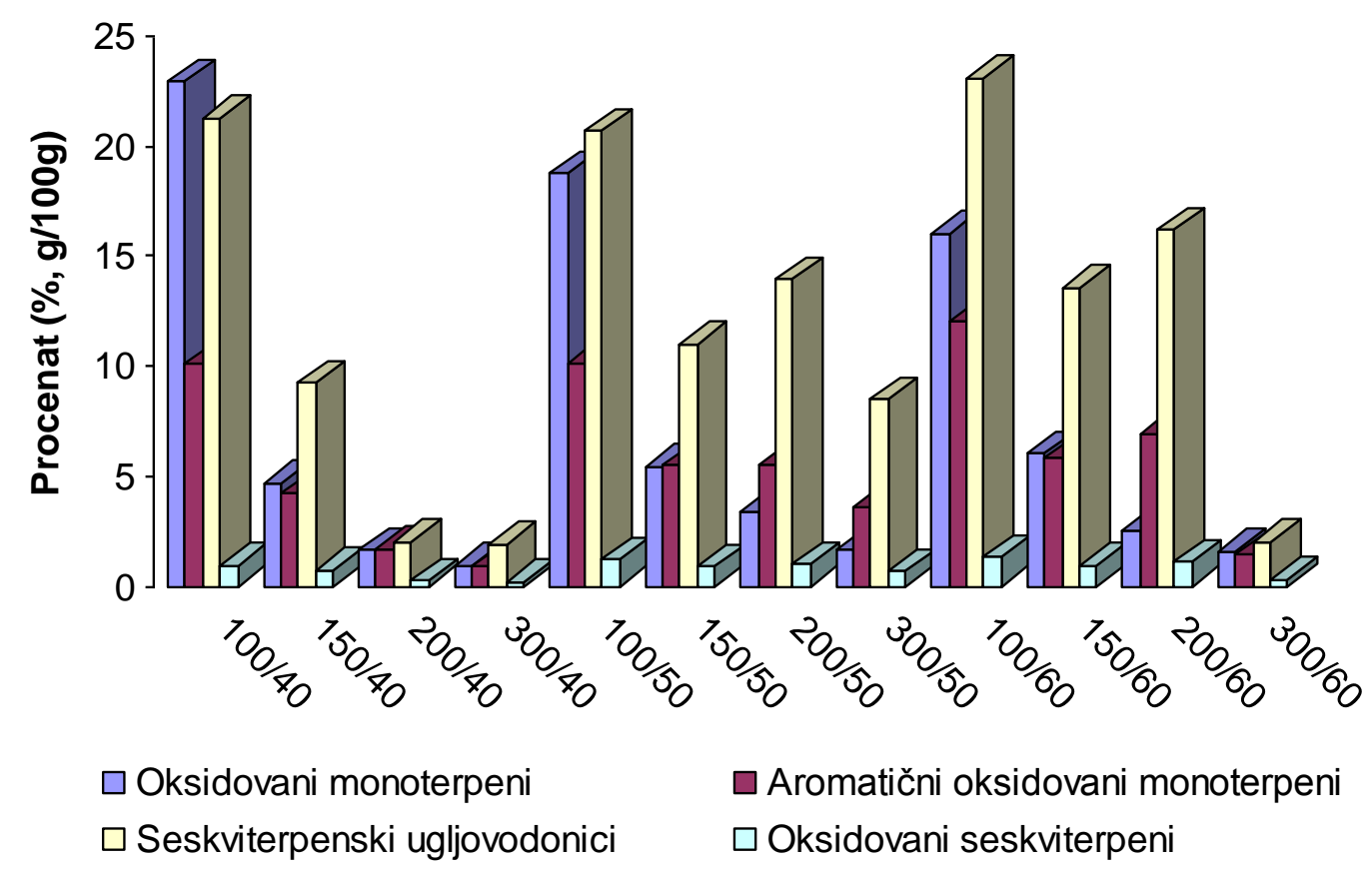

Slika 26. Histogram sadržaja najznačajnijih grupa u ekstraktu bosiljka dobijenih frakcionisanjem

U ekstraktima bosiljka dobijenim frakcionisanjem dominatne su sledeće komponente: linalool, eugenol, $\alpha$-bergamoten, germakren D, $\gamma$-kadinen, $\delta$-kadinen, $\beta$-selinen i spatulenol.

Najveći sadržaj linaloola (20,71\%) određen je u ekstraktu 100/40, ali najveći prinos linaloola koji je ekstrahovana iz 100 g droge nije dobijen pri ovim ekstrakcionim uslovima. Najveći prinos linaloola tokom ekstrakcije je dobijen pri pritisku od 100 bar i temperaturi $50^{\circ} \mathrm{C}$ (uzorak 100/50) i iznosi 167,03 mg/100 g droge (tabela 20). Prinos linaloola opada od 167,03 mg/100 g droge do 3,67 mg/100 g droge sa porastom pritiska (od 100 do 300 bar) pri konstantnoj temperaturi $\left(50^{\circ} \mathrm{C}\right)$ sa iscrpljivanjem droge.

U grupi aromatičnih oksidovanih monoterpena najveći prinos eugenola od 93,74 mg/100 g droge je određen u ekstraktu 100/50, iako je najveći udeo ove komponente $(11,29 \%)$ u ekstraktu 100/60. Prinos eugenola opada od $93,74 \mathrm{mg} / 100 \mathrm{~g}$ droge do $12,67 \mathrm{mg} / 100 \mathrm{~g}$ droge sa porastom pritiska $\mathrm{CO}_{2}$ pri konstantnoj temperaturi od $50^{\circ} \mathrm{C}$ sa iscrpljivanjem droge. 
Tabela 20. Prinos ekstrakcije komponenata bosiljka dobijenih frakcionisanjem (mg/100 g droge)

\begin{tabular}{|c|c|c|c|c|c|c|c|c|c|c|c|c|}
\hline \multirow{3}{*}{ Komponente } & \multicolumn{12}{|c|}{ Sadržaj komponente (mg/100 g droge) } \\
\hline & \multicolumn{12}{|c|}{ Pritisak (bar)/temperatura $\left({ }^{\circ} \mathbf{C}\right)$} \\
\hline & $100 / 40$ & $150 / 40$ & $200 / 40$ & $300 / 40$ & 100/50 & $150 / 50$ & 200/50 & $\mathbf{3 0 0 / 5 0}$ & $100 / 60$ & $150 / 60$ & $200 / 60$ & $300 / 60$ \\
\hline Oksidovani monoterpeni & 158,97 & 20,54 & 4,36 & 1,25 & 189,2 & 37,5 & 11,73 & 5,71 & 105,31 & 50,62 & 12,13 & 3,64 \\
\hline 1,8-Cineol & 2,08 & 2,06 & - & - & 2.82 & - & - & - & 0,66 & 0 & 0 & 0 \\
\hline Linalool & 143,52 & 14,72 & 3,25 & 1,02 & 167,03 & 32,85 & 10,06 & 3,67 & 92,96 & 43,22 & 9,67 & 2,85 \\
\hline Kamfor & 1,59 & - & - & - & 1.41 & - & - & - & 1,18 & 0 & 0 & 0 \\
\hline$\alpha$-Terpineol & 4,44 & 2,45 & 0,43 & - & 6,75 & 2,29 & 0,49 & 0,81 & 3,88 & 2,86 & 0,71 & 0 \\
\hline Geraniol & 5,61 & 1,31 & 0,68 & 0,23 & 8,37 & 2,36 & 1,18 & 1,23 & 5,12 & 3,11 & 1,75 & 0,79 \\
\hline Bornilacetat & 1,73 & - & - & - & 2.82 & - & - & - & 1,51 & 1,43 & - & - \\
\hline Aromatični oksidovani monoterpeni & 69,92 & 18,48 & 4,61 & 1,20 & 102,41 & 38,05 & 19,10 & 12,67 & $\mathbf{7 8 , 9 7}$ & 48,69 & 32,8 & 3,35 \\
\hline $\begin{array}{l}\text { Eugenol } \\
\end{array}$ & 62,16 & 17,74 & 4,61 & 1,20 & 93,74 & 36,66 & 19,10 & 12,67 & 74,17 & 47,01 & 32,80 & 3,35 \\
\hline Metil-havikol & 7,76 & 0,74 & - & - & 8,67 & 1,39 & - & - & 4,80 & 1,68 & - & - \\
\hline Seskviterpenski ugljovodonici & 147,4 & 40,39 & 5,45 & 2,63 & 208,75 & 76,29 & 48,57 & 29,96 & 151,65 & 114,28 & $\mathbf{7 6 , 8 5}$ & 4,63 \\
\hline$\beta$-Kubeben & 4,23 & 0,88 & 0,22 & - & 4,23 & 1,80 & 1,98 & 0,74 & 4,34 & 2,61 & 2,09 & - \\
\hline$\beta$-Elemen & 4,50 & 1,53 & - & - & 6,35 & 2,15 & 2,33 & 0,67 & 4,34 & 2,44 & 2,89 & - \\
\hline Trans-Kariofilen & 3,33 & 1,10 & - & - & 3,83 & 1,87 & - & - & 2,76 & 2,35 & - & - \\
\hline$\alpha$-Bergamoten & 22,73 & 6,53 & 1,60 & 0,37 & 32,36 & 11,43 & 6,40 & 3,49 & 22,99 & 14,30 & 9,53 & 0,94 \\
\hline$\alpha$-Humulen & 6,03 & 1,14 & 0,14 & - & 5,64 & 2,08 & 1,74 & 0,63 & 3,42 & 3,95 & 2,23 & - \\
\hline Germakren D & 24,88 & 4,69 & 1,08 & 0,25 & 30,94 & 9,15 & 6,02 & 3,28 & 22,21 & 13,20 & 8,77 & 0,65 \\
\hline$\gamma$-Kadinen & 17,95 & 6,00 & 0,08 & 0,37 & 27,52 & 9,35 & 6,75 & 4,38 & 19,64 & 16,99 & 10,57 & 0,42 \\
\hline$\delta$-Kadinen & 43,45 & 15,02 & - & 1,49 & 71,77 & 31,88 & 18,44 & 12,78 & 51,97 & 46,67 & 30,86 & 2,39 \\
\hline$\alpha$-Selinen & 4,64 & 1,14 & 0,30 & - & 6,15 & 1,59 & 1,57 & 1,91 & 4,34 & 3,45 & 4,22 & - \\
\hline$\beta$-Selinen & 12,26 & 2,36 & 1,46 & 0,15 & 17,44 & 4,99 & 3,34 & 2,08 & 13,14 & 8,32 & 5,69 & 0,23 \\
\hline$\gamma$-Elemen & 3,40 & - & 0,57 & - & 2,52 & - & - & - & 2,50 & - & - & - \\
\hline Oksidovani seskviterpeni & 6,39 & 3,24 & 0,68 & $\mathbf{0 , 2 3}$ & 11,99 & 6,10 & 3,41 & 2,29 & 8,74 & 8,07 & 5,17 & 0,68 \\
\hline Spatulenol & 6,39 & 3,24 & 0,68 & 0,23 & 11,99 & 6,10 & 3,41 & 2,29 & 8,74 & 8,07 & 5,17 & 0,68 \\
\hline Ukupno & 382,68 & 82,65 & 15,10 & 5,31 & 512,35 & 157,94 & 82,81 & 50,63 & 344,67 & 221,66 & 126,95 & 12,3 \\
\hline
\end{tabular}


$\delta$-Kadinen je dominatna komponenta u grupi seskviterpenskih ugljovodonika sa najvećim udelom u ekstraktu bosiljka 100/60 u iznosu od 7,91\%. Najveći prinos $\delta$-kadinena, na osnovu proračuna, je dobijen u ekstraktu 100/50 (71,77 mg/100 g droge) pri čemu ova vrednost, sa porastom pritiska $\left(100\right.$ - 300 bar) pri konstantnoj temperaturi $\left(50^{\circ} \mathrm{C}\right)$, opada do $12,78 \mathrm{mg} / 100 \mathrm{~g}$ droge. $U$ istoj grupi najveći udeo $\gamma$-kadinena (2,99\%), $\alpha$-bergamotena $(3,50 \%)$ i $\beta$-selinena $(2,0 \%)$ je ostvaren u ekstraktu 100/60, dok je sadržaj germakrena D (3,59\%) imao najveću vrednost u ekstraktu bosiljka 100/40. Prinos ove četiri komponente bio je, takođe, najveći u ekstraktu 100/50 i iznosio je za $\gamma$-kadinen 27,52 mg/100 g, za $\alpha$-bergamoten 32,36 mg/100 g, $\beta$-selinen 17,44 mg/100 g i za germakrena D 30,94 mg/100 g droge.

Spatulenol kao predstavnik oksidovanih seskviterpena najveći udeo imao je u ekstraktu 100/60 i iznosio je 1,33\%, odnosno u 100 g droge najveći prinos spatulenola od 11,99 mg/100 g bio je u ekstraktu bosiljka 100/50.

Treba napomenuti da sadržaj svih komponenata ( $\gamma$-kadinen, $\alpha$-bergamoten, $\beta$-selinen, germakrena D i spatulenol) opada tokom ekstrakcije (sa porastom pritiska od 100 do 300 bar pri konstantnoj temperaturi od $50^{\circ} \mathrm{C}$ ) sa iscrpljivanjem droge. Pojedine komponente, kao što su 1,8 cineol, kamfor, bornilaceta, metil-havikol, trans-kariofilen i $\gamma$-elemen, su potpuno ekstrahovane u prethodnim stepenima ekstrakcije.

$\mathrm{Na}$ osnovu rezultata datih u tabeli 20 može se uočiti da je za izdvajanje etarskog ulja iz ispitivane droge najpogodnija kombinacija radnih uslova superkritične ekstrakcije pritiska 100 bar $\mathrm{i}$ temperature $50^{\circ} \mathrm{C}$, odnosno odgovarajuće gustine $\mathrm{CO}_{2}\left(0,378 \mathrm{~kg} / \mathrm{m}^{3}\right)$. Ovu konstataciju potvrđuje zaključak Reverchona i de Marca (2006) o optimalnim uslovima ekstrakcije od 80 do 100 bar i temperaturi od 40 do $50^{\circ} \mathrm{C}$.

Upoređujući rezultate dominatnih komponenti u totalnim ekstraktima i ekstraktima dobijenih frakcionisanjem lipofilnih komponenata, mogu se videti značajno veće količine ovih komponenata na višim pritiscima (većim gustinama $\mathrm{CO}_{2}$ ), iako je od strane velikog broja autora $\mathrm{u}$ literaturi predložena ekstrakcija EO pri „blagim“ ekstrakcionim uslovima (pritisak od 80 do 100 bar i temperatura od 40 do $50^{\circ} \mathrm{C}$ ). Najveći prinos linaloola (tabela 17) od 199,75 mg/100 g droge dobijen je pri ekstrakciji bosiljka na pritisku od 200 bar i temperaturi od $40^{\circ} \mathrm{C}$ (gustina $\mathrm{CO}_{2} 0,831$ $\mathrm{kg} / \mathrm{m}^{3}$ ). Nadalje, najveći prinos eugenola od 123,29 mg/100 g droge dobijen je pri ekstrakciji bosiljka na pritisku od 150 bar i temperaturi od $60^{\circ} \mathrm{C}$ (gustina $\mathrm{CO}_{2} 0,563 \mathrm{~kg} / \mathrm{m}^{3}$ ). Najveći prinos $\delta$ kadinena od $91,79 \mathrm{mg} / 100 \mathrm{~g}$ droge dobijen je pri ekstrakciji bosiljka na pritisku od 150 bar i temperaturi od $50^{\circ} \mathrm{C}$.

$\mathrm{Na}$ osnovu dobijenih rezultata može se zaključiti da se odabirom ekstrakcionih uslova (temperature, pritiska, odnosno gustine i protoka ekstragensa) može uticati na selektivnost 
superkritične ekstrakcije, a samim tim i na sastav dobijenog ekstrakta.

\subsection{OPTIMIZACIJA EKSTRAKCIJE BOSILJKA METODOM ODZIVNE POVRŠINE (RSM)}

Radi utvrđivanja najpogodnijih uslova ekstrakcije i dobijanja maksimalnog prinosa linaloola izvršena je optimizacija procesa ekstrakcije primenom Metode odzivne površine (poglavlje 4.6.) U okviru ovog rada je korišćen $3^{2}$ faktorijalni dizajn gde je ispitan uticaj dve nezavisne promenljive (pritisak i temperatura) na prinos ekstrakcije (Y, \%) i na prinos linaloola (g/100 g), koji je dominantno jedinjenje ekstrakata dobijenih supekritičnim $\mathrm{CO}_{2}$. Kodirane vrednosti nezavisnih promenljivih su dobijene korišćenjem jednačine 63 (eksperimentalni deo 4.6.).

U tabeli 21 su prikazane dobijene vrednosti prinosa ekstrakcije i linaloola pri različitim kombinacijama ekstrakcionih parametara (pritisak i temperatura), pri čemu su svi ostali parametri (vreme ekstrakcije, stepen usitnjenosti i dr.) održavani konstantnim.

Tabela 21. Eksperimentalni dizajn $3^{2}$ i vrednosti nezavisnih promenljivih pri različitim ulaznim veličinama

\begin{tabular}{ccccc}
\hline Proba & Pritisak (bar) & Temperatura $\left({ }^{\circ} \mathbf{C}\right)$ & Y $(\%)$ & Linalool (g/100 g) \\
\hline 1 & $100(-1)$ & $40(-1)$ & 0,719 & 16,60 \\
2 & $200(0)$ & $40(-1)$ & 1,322 & 15,11 \\
3 & $300(1)$ & $40(-1)$ & 1,287 & 10,72 \\
4 & $100(-1)$ & $50(0)$ & 0,894 & 11,79 \\
5 & $200(0)$ & $50(0)$ & 1,447 & 9,58 \\
6 & $300(1)$ & $50(0)$ & 1,715 & 10,14 \\
7 & $100(-1)$ & $60(1)$ & 0,382 & 10,00 \\
8 & $200(0)$ & $60(1)$ & 1,666 & 9,66 \\
9 & $300(1)$ & $60(1)$ & 1,879 & 6,99 \\
\hline
\end{tabular}

Vrednosti za ukupan prinos ekstrakcije su se kretale od 0,382 do 1,879\% u zavisnosti od primenjenih uslova ekstrakcije. Najveća vrednost prinosa ekstrakcije $(1,879 \%)$ dobijena je pri pritisku od 300 bar i temperaturi od $60^{\circ} \mathrm{C}$ (maksimalni nivo vrednosti nezavisnih promenljivih).

Vrednosti regresionih koeficijenata sa nivoom značajnosti, koeficijent determinacije $\left(\mathrm{R}^{2}\right) \mathrm{i}$ koeficijent varijacije (KV) prikazani su u tabeli 22. 
Tabela 22. Regresioni koeficijenti za predviđeni model

\begin{tabular}{|c|c|}
\hline $\begin{array}{l}\text { Regresioni } \\
\text { koeficijent }\end{array}$ & $\begin{array}{c}\text { Prinos } \\
\text { ekstrakcije }\end{array}$ \\
\hline$\beta_{\mathrm{o}}$ & $1,573556^{*}$ \\
\hline \multicolumn{2}{|c|}{ Linearni } \\
\hline$\beta_{1}$ & $0,481000^{*}$ \\
\hline$\beta_{2}$ & 0,099833 \\
\hline \multicolumn{2}{|c|}{ Interakcija } \\
\hline$\beta_{12}$ & $0,232250^{* * *}$ \\
\hline \multicolumn{2}{|c|}{ Kvadratni } \\
\hline$\beta_{11}$ & $-0,332330^{* * *}$ \\
\hline$\beta_{22}$ & $-0,142830$ \\
\hline $\mathrm{R}^{2}$ & 0,966580 \\
\hline $\mathrm{KV}$ & 11,852910 \\
\hline
\end{tabular}

Izrazito visoka vrednost koeficijenta determinacije $(0,96658)$ ukazuje na odlično slaganje eksperimentalnih vrednosti sa predviđenim kvadratnim modelom. U prilog ovoj tvrdnji ide $\mathrm{i}$ relativno niska vrednost koeficijenta varijacije i grafik koji pokazuje zavisnost vrednosti predviđenih matematičkim modelom $\left(\mathrm{Y}_{\text {pred }}\right)$ od eksperimentalno dobijenih vrednosti $\left(\mathrm{Y}_{\mathrm{eksp}}\right)$ odakle se može uočiti da su tačke blisko grupisane oko prave (slika 27).

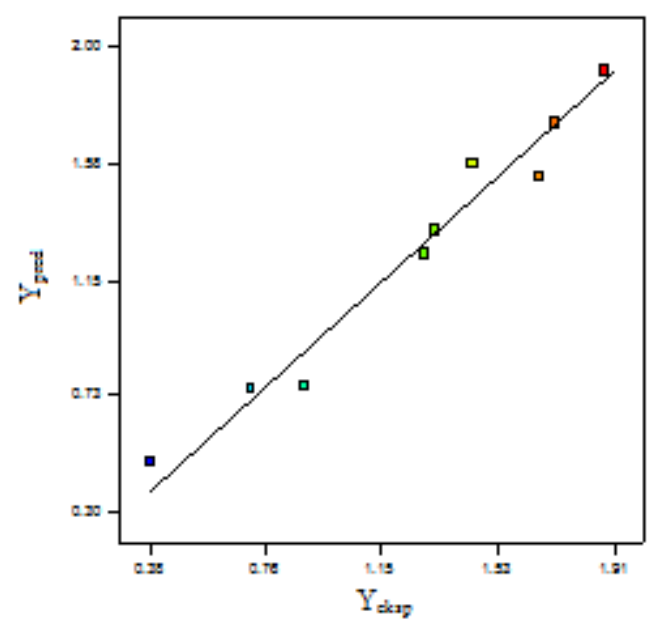

Slika 27. Raspodela predviđenih i eksperimentalno dobijenih vrednosti prinosa ekstrakcije

Analiza varijanse (ANOVA) za ispitivani model je prikazana u tabeli 23. Na osnovu $F$ vrednosti može se zaključiti da pretpostavljeni model dobro opisuje ispitivani sistem $(p<0,05)$, što ukazuje i relativno nizak udeo sume kvadrata za ostatak koji je relativno nizak u poređenju sa sumom kvadrata za ispitani model. 
Tabela 23. ANOVA za ispitivani model

\begin{tabular}{cccccc}
\hline & $\mathbf{S S}^{\mathbf{a}}$ & $\mathbf{D f}^{\mathbf{b}}$ & $\mathbf{M S}^{\mathbf{c}}$ & $\boldsymbol{F}$-vrednost & $\boldsymbol{p}_{\text {-vrednost }}$ \\
\hline Model & 1,925420 & 5 & 0,385084 & 17,35355 & 0,0201 \\
Ostatak & 0,066572 & 3 & 0,022191 & & \\
Ukupno & 1,991992 & 8 & & & \\
\hline
\end{tabular}

\footnotetext{
${ }^{a}$ Suma kvadrata

${ }^{\mathrm{b}}$ Broj stepeni slobode

${ }^{\mathrm{c}}$ Srednja vrednost kvadrata
}

Može se zaključiti da na ukupan prinos ekstrakcije najznačajnije utiče linearni član pritiska $(p<0,05)$. Ovo se može potvrditi i sa slike 28 , gde se vidi jasno izražen pozitivan uticaj pritiska na vrednost Y. Interakcija između nezavisnih promenljivih, kao i kvadratni član radnog pritiska imaju značajan $(p<0,1)$ uticaj na prinos. Negativna vrednost kvadratnog člana pritiska ukazuje da prinos na određenoj vrednosti pritiska dostiže svoj maksimum nakon čega njegovim daljim povećanjem dolazi do opadanja prinosa. Sa grafika se može uočiti da se prevojna tačka (maksimum) nalazi na vrednostima pritiska i temperature bliskim maksimalnim (slika 28). Uticaj ostalih članova na ukupan prinos ekstrakcije nije značajnije izražen $(p>0,1)$.

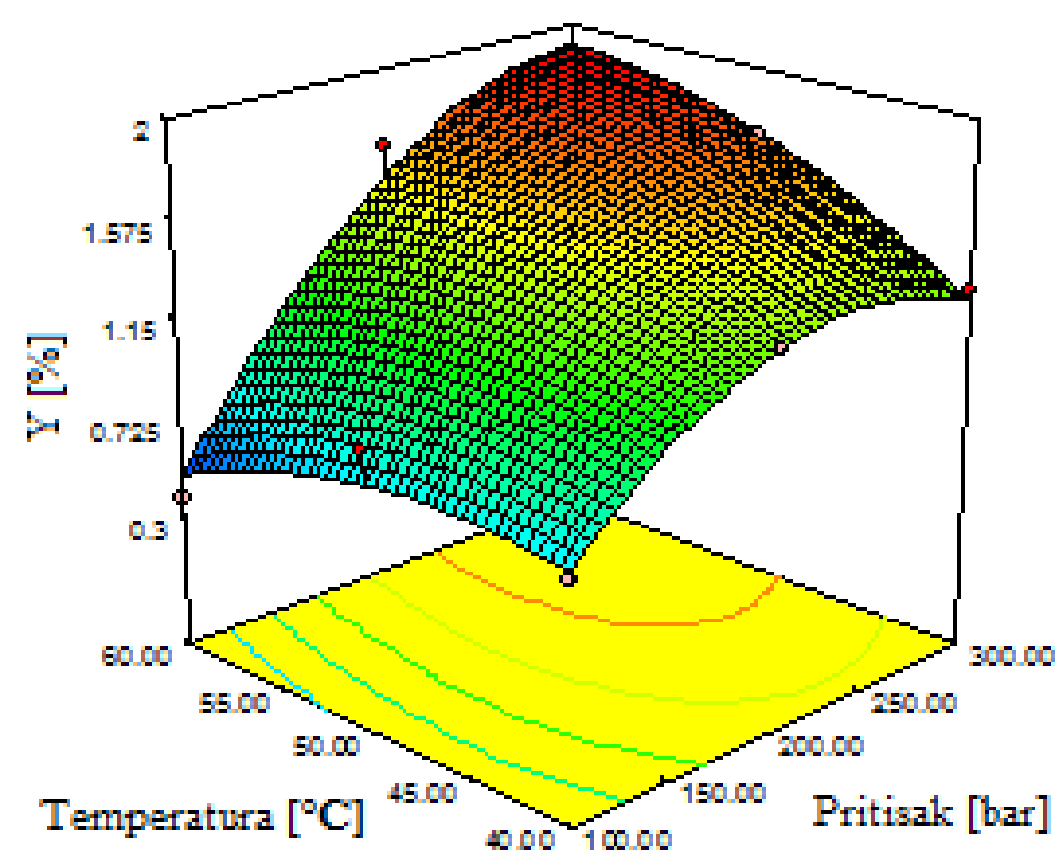

Slika 28. Uticaj ekstrakcionih parametara na prinos ekstrakcije

Matematički model koji opisuje ispitivani sistem $\left(\mathrm{R}^{2}=0,967\right)$ je prikazan sledećom polinomnom jednačinom drugog reda:

$$
Y=1,573556+0,481 p+0,099833 t+0,23225 p t-0.33233 p^{2}-0,14283 t^{2}
$$


U cilju intenzifikacije procesa ekstrakcije izvršena je optimizacija parametara ekstrakcije korišćenjem jednačine (59). Izračunate vrednosti za pritisak, odnosno temperaturu bile su 297 bar i $59,2^{\circ} \mathrm{C}$. Matematički model predviđa da će vrednost prinosa ekstrakcije ( $\left.\mathrm{Y}_{\text {pred }}\right)$ izvedene pri navedenim uslovima biti $1,91 \%$, odnosno da će interval poverenja za eksperimentalno dobijenu vrednost sa $95 \%$ sigurnosti biti od 1,52 do 2,29\%. S obzirom da su najveći prinosi ekstrakcije eksperimentalno dobijeni pri sličnim uslovima $\left(300\right.$ bar i $\left.60^{\circ} \mathrm{C}\right)$, kao i da se prevojna tačka na površini prikazanoj na slici 28 nalazi u tom intervalu, može se zaključiti da je optimizacija uspešno izvršena.

U cilju definisanja ekstrakcionih parametara (temperature i pritiska) pri kojima bi prinos linaloola (g/100 g ekstrakta) bio najveći, optimizacija nije mogla da bude na isti način izvršena zbog toga što kvadratni model opisan jednačinom (65) ne opisuje dobro sistem $(p>0,05)$. Ustanovljeno je da linearni model opisan jednačinom (60) bolje opisuje ekstrakcioni sistem.

$$
Y=\beta_{\mathrm{o}}+\beta_{1} X_{1}+\beta_{2} X_{2}
$$

gde regresioni koeficijenti $(\beta)$ i nezavisne promenljive $\left(\mathrm{X}_{1} \mathrm{i} \mathrm{X}_{2}\right)$ imaju isto značenje kao u jednačini (59), dok Y označava prinos linaloola. Linearni model relativno dobro opisuje ispitivani sistem $(p<0,05)$, ipak nešto niža vrednost koeficijenta determinacije $\left(\mathrm{R}^{2}=0,85\right)$ ukazuje na izvesne nedostatke. Linearni model koji matematički opisuje ponašanje sistema prikazan je jednačinom (61), a uticaj pojedinih faktora na prinos linaloola može se videti na slici 29.

$$
\mathrm{Y}=11,17667-1,75667 \mathrm{p}-2,63 \mathrm{t}
$$
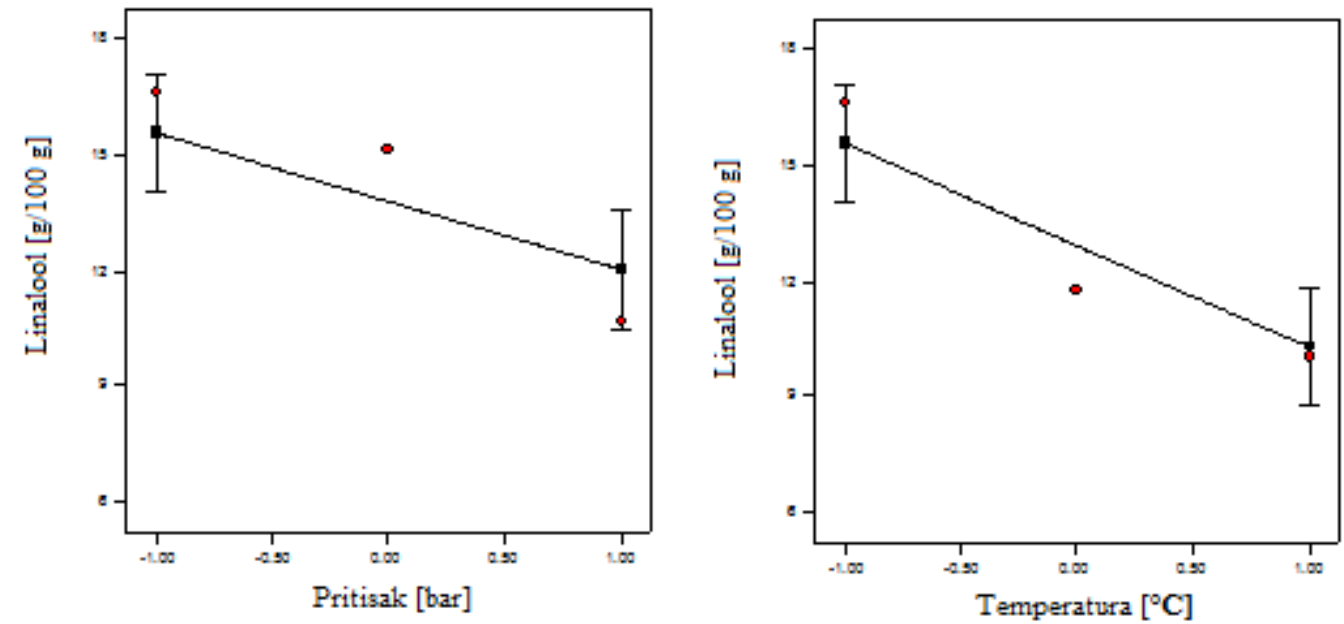

Slika 29. Uticaj ekstrakcionih parametara na prinos linaloola

Prvi grafik pokazuje uticaj pritiska na prinos linaloola pri temperaturi od $40^{\circ} \mathrm{C}(-1)$, dok drugi prikazuje uticaj temperature na istu veličinu pri pritisku od 100 bar (-1). Može se vidi da oba 
parametra imaju negativan uticaj na prinos linaloola, a izraženiji je uticaj temperature, što se odražava većim nagibom duži u odnosu na horizontalnu osu. S obzirom da je najveća eksperimentalna vrednosta za prinos linaloola dobijena na najnižim nivoima pritiska i temperature (100 bar i $\left.40^{\circ} \mathrm{C}\right)$, za očekivati je da optimalni parametri budu u blizini ovih vrednosti.

\subsection{MATEMATIČKO MODELOVANJE SUPERKRITIČNE EKSTRAKCIJE BOSILJKA}

Matematički modeli koji se koriste za opisivanje procesa superkritične ekstrakcije najčešće imaju jedan, dva ili više parametara, koje je neophodno izračunati, odnosno prilagoditi njihove vrednosti eksperimentalnim podacima. Kao rezultat matematičkog modelovanja, dobijene su vrednosti parametara različitih primenjenih modela minimizirajući odstupanje vrednosti prinosa izračunatih modelom od odgovarajućih eksperimentalnih vrednosti i izračunate srednje vrednosti relativnog odstupanja (AARD).

Za opisivanje kinetike superkritične ekstrakcije u ovom radu primenjena su tri modela (Kandiah i Spiro, Brunner i Esquivel i sar.) prema izrazima (1), (16) i (36), koji su dati u teorijskom delu rada. Programskim paketima Mathcad 14 i Solver dodatkom unutar Microsoft Excel 2007, određeni su parametri ispitivanih modela u cilju najboljeg slaganja modela sa eksperimentalnim podacima. U tabelama 24,25 i 26 dati su rezultati primenjenih matematičkih modela i njihova srednja relativna odstupanja.

Tabela 24. Parametri Kandiah i Spiro modela pri različitim uslovima superkritične ekstrakcije

\begin{tabular}{cccccc}
\hline $\begin{array}{c}\text { Ekstrakcioni } \\
\text { uslovi }\end{array}$ & $f_{1}$ & $f_{2}$ & $\begin{array}{c}k_{1} \\
(1 / \mathrm{h})\end{array}$ & $\begin{array}{c}k_{2} \\
(1 / \mathrm{h})\end{array}$ & $\begin{array}{c}\text { AARD } \\
(\%)\end{array}$ \\
\hline $100 \mathrm{bar}, 40^{\circ} \mathrm{C}$ & 0,4756 & 0,4754 & 0,1207 & 0,1204 & 8,947 \\
$100 \mathrm{bar}, 50^{\circ} \mathrm{C}$ & 0,4719 & 0,4829 & 0,1660 & 0,1660 & 11,795 \\
$100 \mathrm{bar}, 60^{\circ} \mathrm{C}$ & 0,4950 & 0,4950 & 0,0505 & 0,0505 & 7,688 \\
$150 \mathrm{bar}, 40^{\circ} \mathrm{C}$ & 0,5054 & 0,5064 & 0,2654 & 0,2654 & 7,516 \\
$150 \mathrm{bar}, 50^{\circ} \mathrm{C}$ & 0,5368 & 0,3906 & 0,5360 & 0,3906 & 25,227 \\
$150 \mathrm{bar}, 60^{\circ} \mathrm{C}$ & 0,5145 & 0,3071 & 0,4952 & 0,3071 & 14,235 \\
$200 \mathrm{bar}, 40^{\circ} \mathrm{C}$ & 0,4450 & 0,3343 & 0,4385 & 0,3343 & 11,319 \\
$200 \mathrm{bar}, 50^{\circ} \mathrm{C}$ & 0,4974 & 0,3231 & 0,4996 & 0,3231 & 9,522 \\
$200 \mathrm{bar}, 60^{\circ} \mathrm{C}$ & 0,5398 & 0,4258 & 0,5399 & 0,4258 & 38,211 \\
$300 \mathrm{bar}, 40^{\circ} \mathrm{C}$ & 0,4952 & 0,4953 & 0,2700 & 0,2700 & 16,213 \\
$300 \mathrm{bar}, 50^{\circ} \mathrm{C}$ & 0,5271 & 0,5157 & 0,6139 & 0,6139 & 10,603 \\
$300 \mathrm{bar}, 60^{\circ} \mathrm{C}$ & 0,5323 & 0,5323 & 0,6104 & 0,6104 & 25,452 \\
\hline
\end{tabular}


Tabela 25. Parametri Brunner modela

\begin{tabular}{ccc}
\hline $\begin{array}{c}\text { Ekstrakcioni } \\
\text { uslovi }\end{array}$ & $\begin{array}{c}k \\
(1 / \mathrm{h})\end{array}$ & $\begin{array}{c}\text { AARD } \\
(\%)\end{array}$ \\
\hline $100 \mathrm{bar}, 40^{\circ} \mathrm{C}$ & 0,1407 & 17,455 \\
$100 \mathrm{bar}, 50^{\circ} \mathrm{C}$ & 0,1812 & 10,459 \\
$100 \mathrm{bar}, 60^{\circ} \mathrm{C}$ & 0,0541 & 10,492 \\
$150 \mathrm{bar}, 40^{\circ} \mathrm{C}$ & 0,260 & 8,527 \\
$150 \mathrm{bar}, 50^{\circ} \mathrm{C}$ & 0,3549 & 40,899 \\
$150 \mathrm{bar}, 60^{\circ} \mathrm{C}$ & 0,3026 & 14,036 \\
$200 \mathrm{bar}, 40^{\circ} \mathrm{C}$ & 0,4103 & 17,068 \\
$200 \mathrm{bar}, 50^{\circ} \mathrm{C}$ & 0,3246 & 9,306 \\
$200 \mathrm{bar}, 60^{\circ} \mathrm{C}$ & 0,3857 & 50,169 \\
$300 \mathrm{bar}, 40^{\circ} \mathrm{C}$ & 0,2745 & 20,342 \\
$300 \mathrm{bar}, 50^{\circ} \mathrm{C}$ & 0,5849 & 12,810 \\
$300 \mathrm{bar}, 60^{\circ} \mathrm{C}$ & 0,5685 & 31,458 \\
\hline
\end{tabular}

Tabela 26. Parametri modela Esquivel i sar.

\begin{tabular}{ccc}
\hline $\begin{array}{c}\text { Ekstrakcioni } \\
\text { uslovi }\end{array}$ & $\begin{array}{c}b \\
(1 / \mathrm{h})\end{array}$ & $\begin{array}{c}\text { AARD } \\
(\%)\end{array}$ \\
\hline $100 \mathrm{bar}, 40^{\circ} \mathrm{C}$ & 5,5971 & 12,2306 \\
$100 \mathrm{bar}, 50^{\circ} \mathrm{C}$ & 4,1378 & 9,173 \\
$100 \mathrm{bar}, 60^{\circ} \mathrm{C}$ & 16,898 & 9,6977 \\
$150 \mathrm{bar}, 40^{\circ} \mathrm{C}$ & 2,7402 & 17,644 \\
$150 \mathrm{bar}, 50^{\circ} \mathrm{C}$ & 1,9309 & 59,639 \\
$150 \mathrm{bar}, 60^{\circ} \mathrm{C}$ & 2,280 & 17,248 \\
$200 \mathrm{bar}, 40^{\circ} \mathrm{C}$ & 1,3967 & 7,186 \\
$200 \mathrm{bar}, 50^{\circ} \mathrm{C}$ & 2,0451 & 15,011 \\
$200 \mathrm{bar}, 60^{\circ} \mathrm{C}$ & 1,7451 & 83,538 \\
$300 \mathrm{bar}, 40^{\circ} \mathrm{C}$ & 2,5242 & 7,155 \\
$300 \mathrm{bar}, 50^{\circ} \mathrm{C}$ & 1,1647 & 22,9154 \\
$300 \mathrm{bar}, 60^{\circ} \mathrm{C}$ & 1,0632 & 48,9251 \\
\hline
\end{tabular}

Uspešnost aproksimacije primenjenih matematičkih modela analizirana je na osnovu srednje vrednosti relativnog odstupanja (AARD, \%) za koju se smatra da je prihvatljiva do 5\%, dok iznad $10 \%$ označava loše slaganje eksperimentalno određenih i modelom predviđenih vrednosti podataka.

Iz tabele 24 uočava se da su vrednosti parametara Kandiah i Spiro modela, baziranog na postojanju hemijske reakcije, $k_{1}$ i $k_{2}$ vrlo slične, kao i da su vrednosti za frakcije ekstrahovane rastvorene supstance $f_{1}$ i $f_{2}$, takođe veoma slične. Stoga se može zaključiti da je model baziran na hemijskoj reakciji moguće primenjivati samo u slučajevima kada je hemijska reakcija tokom procesa ekstrakcije vrlo spora i samim tim ograničavajući uslov procesa, dok su brzine desorpcije, rastvaranja i difuzije ekstrahovanih komponenata prevelike da bi usporavale proces. Na osnovu vrednosti relativnog odstupanja, može se zaključiti da je prihvatljivo fitovanje eksperimentalnih podataka i modela koji su dali Kandiah i Spiro u slučaju ekstrakcije bosiljka na 100 bar $40^{\circ} \mathrm{C}, 150$ bar $40^{\circ} \mathrm{C}$ i 100 bar $60^{\circ} \mathrm{C}$ (slika 30), odnosno na nižim pritiscima i nižoj temperaturi. 


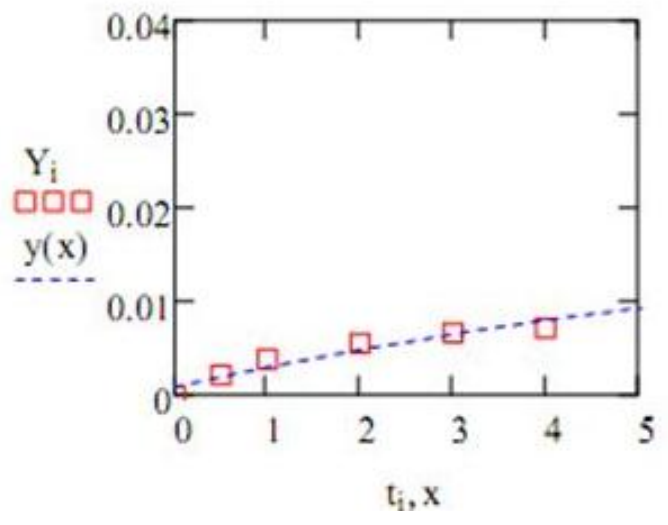

a) 100 bar $40^{\circ} \mathrm{C}$

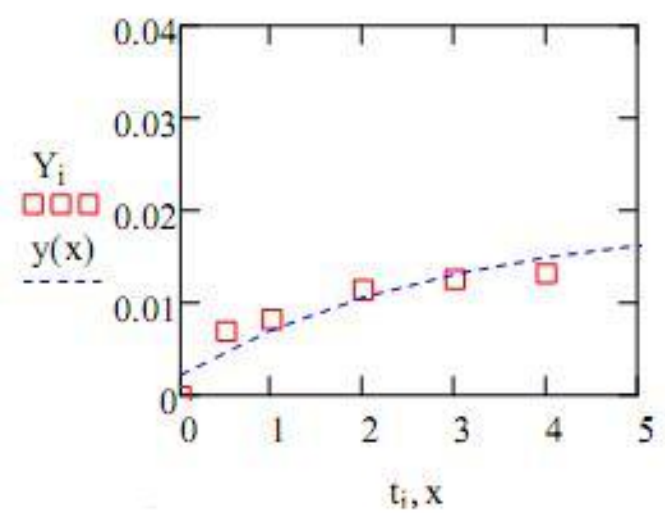

c) 200 bar $40^{\circ} \mathrm{C}$

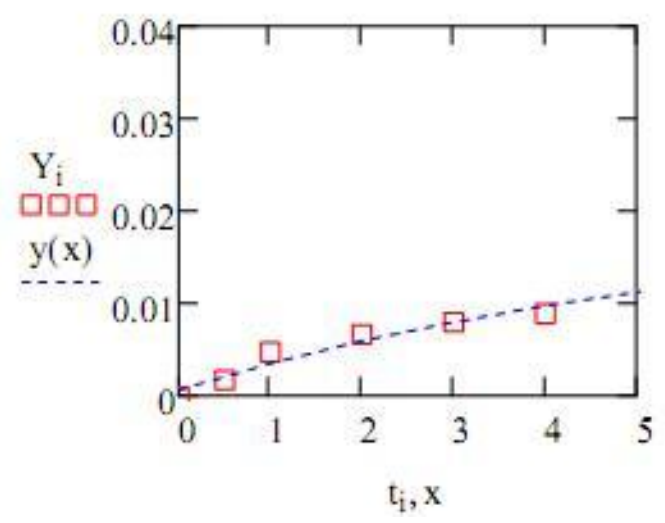

e) 100 bar $50^{\circ} \mathrm{C}$

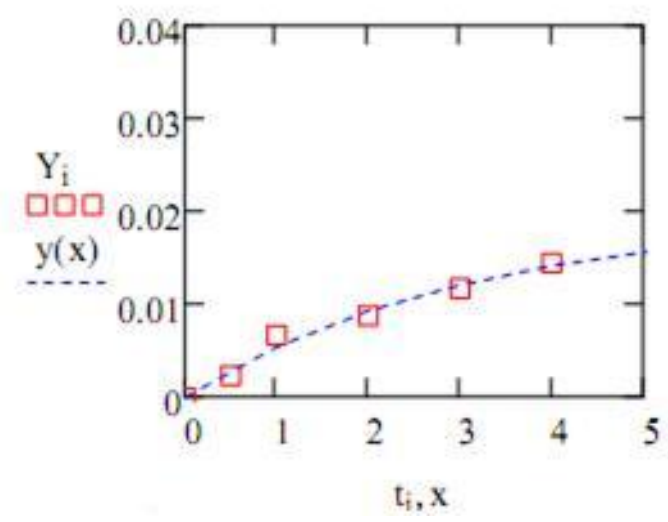

g) $200 \mathrm{bar} 50^{\circ} \mathrm{C}$

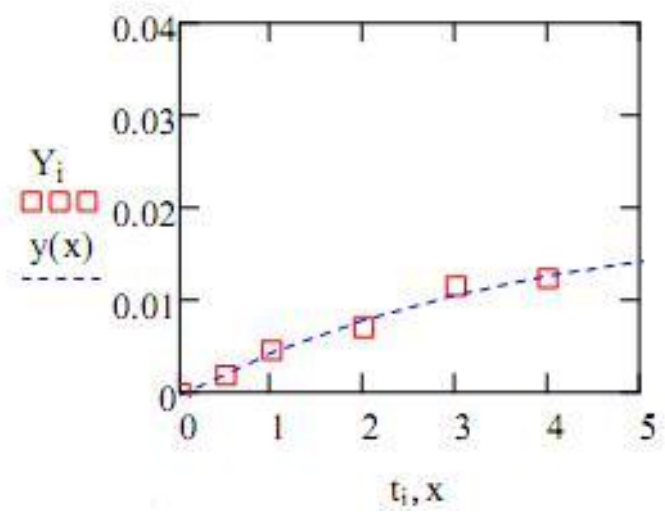

b) 150 bar $40^{\circ} \mathrm{C}$

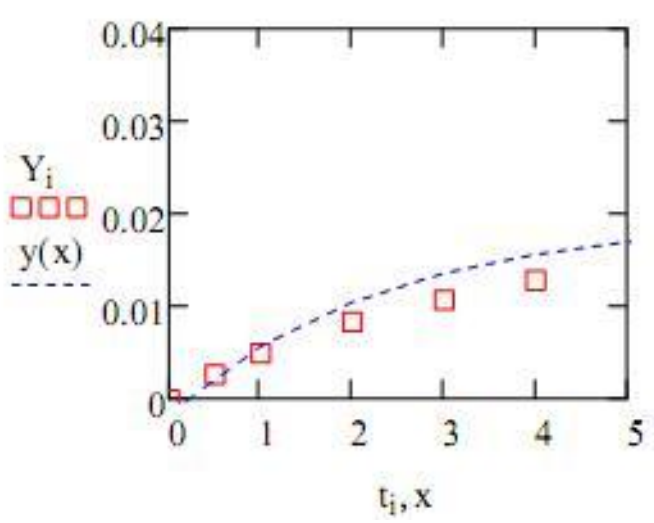

d) $300 \mathrm{bar} 40^{\circ} \mathrm{C}$

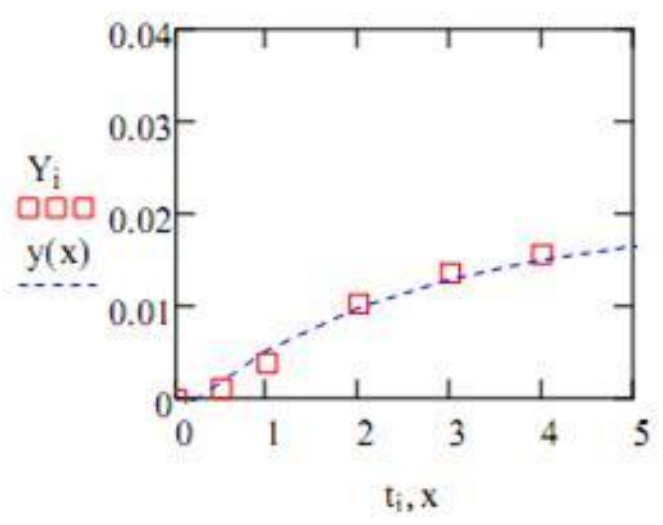

f) $150 \mathrm{bar} 50^{\circ} \mathrm{C}$

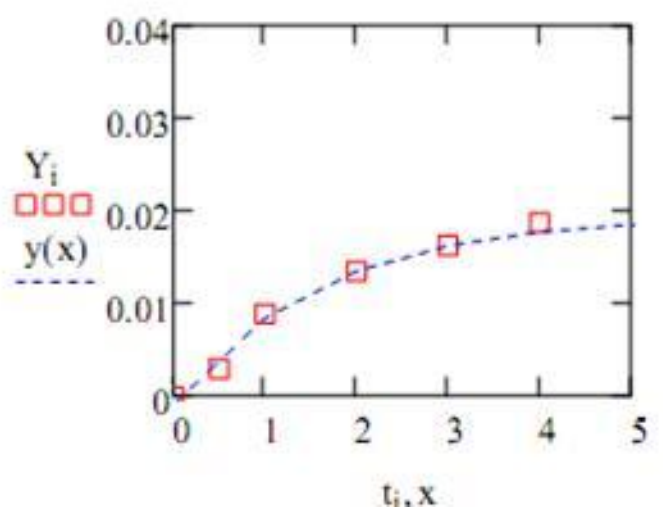

h) $300 \mathrm{bar} 50^{\circ} \mathrm{C}$ 


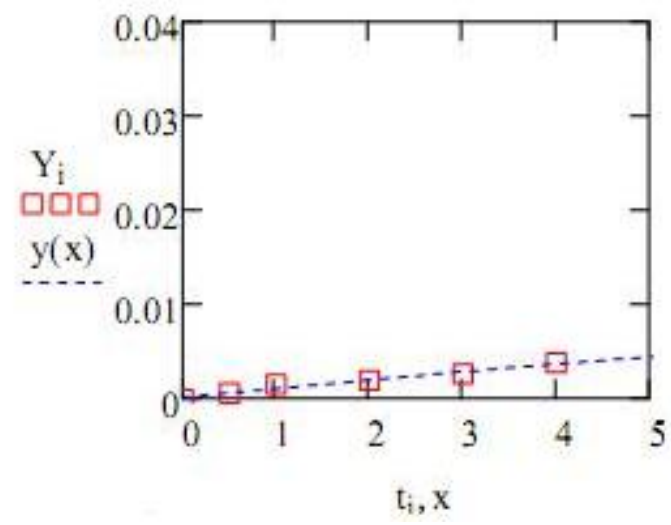

i) 100 bar $60^{\circ} \mathrm{C}$

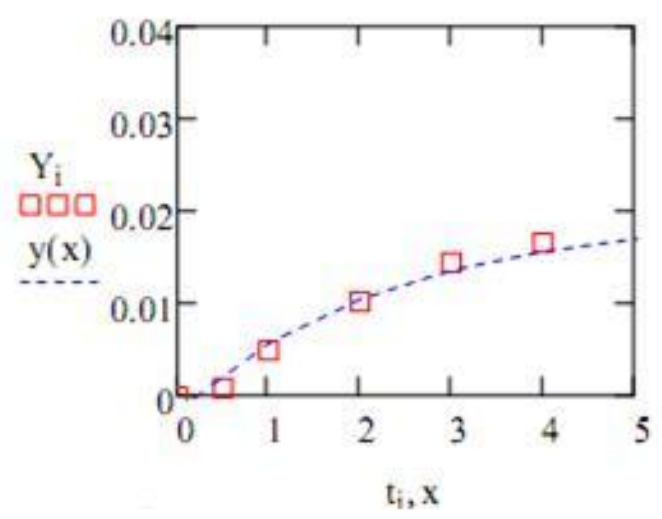

k) 200 bar $60^{\circ} \mathrm{C}$

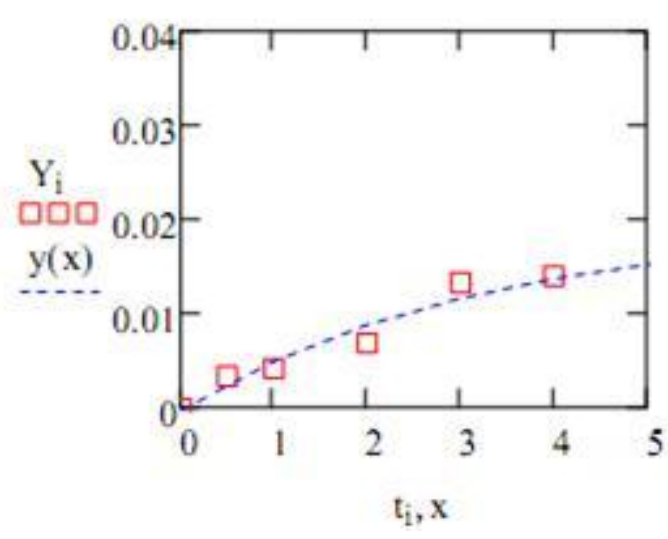

j) 150 bar $60^{\circ} \mathrm{C}$

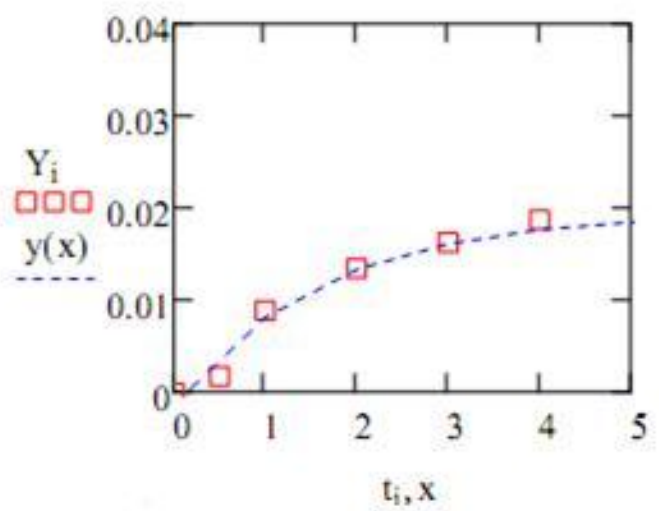

1) 300 bar $60^{\circ} \mathrm{C}$

Slika 30. Poređenje eksperimentalnih i izračunatih vrednosti prinosa ekstrakcije u toku superkritične ekstrakcije bosiljka na različitim pritiscima i temperaturama (simboli - eksperimentalni podaci, isprekidane linije - aproksimacijske krive prema modelu Kandiah i Spiro).

Tabela 25 pokazuje rezultate modelovanja superkritične ekstrakcije pomoću jednostavnog modela koji je predložio Brunner (1984). Ovaj model pretpostavlja da se ekstrakcija odvija u jednom stepenu, gde je difuzija kontrolisana samo pomoću unutrašnjeg prenosa mase. AARD vrednosti se kreću od 8,527\% do 50,169\%, što pokazuje da Brunnerov model pokazuje lošije slaganje eksperimentalno određenih i modelom izračunatih prinosa ekstrakta (osim u slučaju superkritične ekstrakcije na 150 bar, $40^{\circ} \mathrm{C}$ (slika 31$)$. 


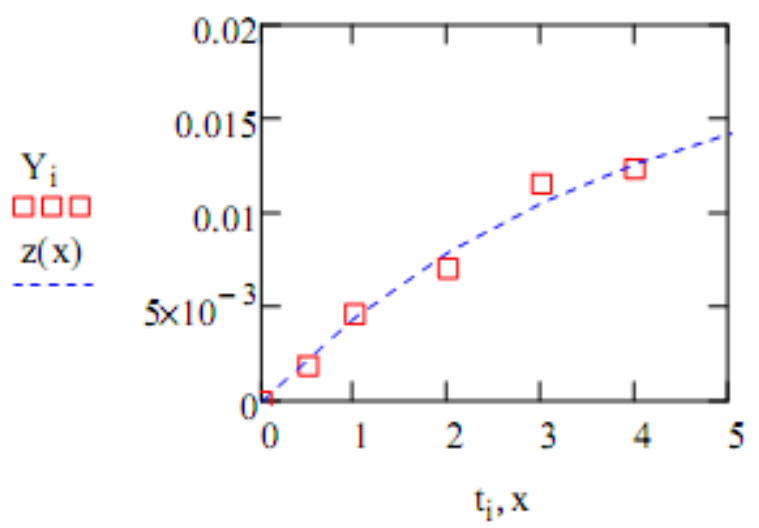

Slika 31. Poređenje eksperimentalnih i izračunatih vrednosti prinosa ekstrakcije u toku superkritične ekstrakcije bosiljka na pritisku 150 bar i temperaturi $40^{\circ} \mathrm{C}$ (simboli - eksperimentalni podaci, isprekidane linije - aproksimacijske krive prema modelu Brunner).

Tabela 26 pokazuje rezultate modelovanja prema jednačini (36) koju su predložili Esquivel i saradnici (1999). Na osnovu AARD vrednosti koje su se kretale od 7,155\% do 83,538\% može se zaključiti, da se osim u slučaju ekstrakcije bosiljka na 200 bar, $40^{\circ} \mathrm{C}$ i 300 bar, $40^{\circ} \mathrm{C}$ (slika 32 ), gde je prihvatljivo fitovanje eksperimentalnih i modelom izračunatih vrednosti prinosa ekstrakcije, $u$ svim ostalim slučajevima pokazano lošije slaganje eksperimentalno određenih i modelom izračunatih prinosa superkritične ekstrakcije.

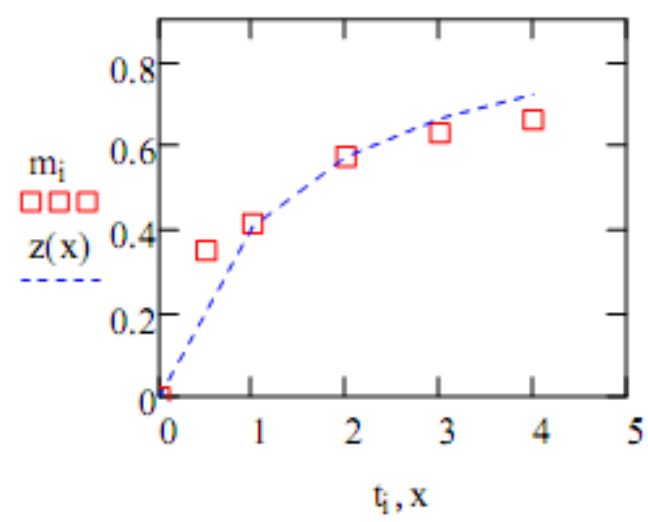

a) $200 \mathrm{bar}, 40^{\circ} \mathrm{C}$

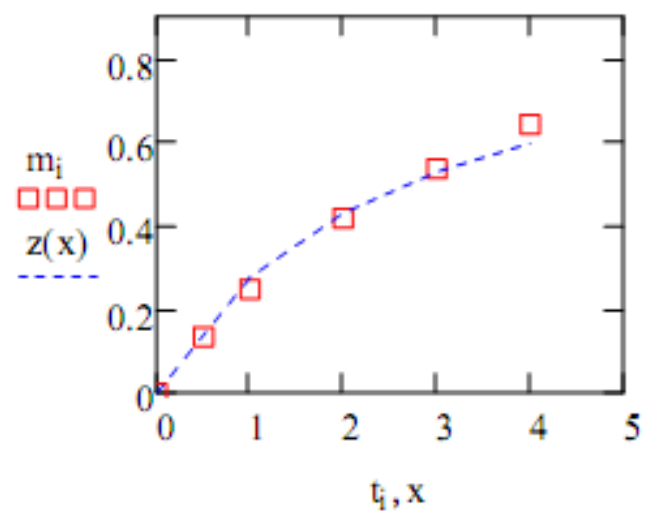

b) 300 bar, $40^{\circ} \mathrm{C}$

Slika 32. Poređenje eksperimentalnih i izračunatih vrednosti prinosa ekstrakcije u toku superkritične ekstrakcije bosiljka na različitim pritiscima i temperaturama (simboli - eksperimentalni podaci, isprekidane linije - aproksimacijske krive prema modelu Esquivel i sar.).

$\mathrm{Na}$ osnovu rezultata dobijenih primenom tri matematička modela (Kandiah i Spiro, Brunner i Esquivel i sar.) može se zaključiti da odabrani modeli ne pokazuju najbolje slaganje eksperimentalno određenih i modelom izračunatih prinosa ekstrakcije. U cilju iznalaženja modela 
koji bi pokazao bolje fitovanje rezultata, dalja istraživanja mogu se usmeriti na odabir modela koji bi preciznije opisao prenos mase u ekstrakcionom sistemu bosiljak-superkritični ugljendioksid.

\subsection{ANTIOKSIDATIVNO DELOVANJE}

Antioksidativna aktivnost etarskog ulja i ekstrakata bosiljka određena je neutralizacijom $\mathrm{DPPH}^{\bullet}$ radikala. Slobodni $\mathrm{DPPH}^{\bullet}$ radikali se najčešće upotrebljavaju u antioksidativnim testovima za određivanje sposobnosti prirodnih sekundarnih metabolita prisutnih u ekstraktima da predaju vodonikov atom slobodnim radikalima. Ovaj mehanizam predstavlja najčešći i najjednostavniji mehanizam antioksidativne zaštite $\left(\mathrm{DPPH}^{\bullet}+\right.$ Antioksidant $\rightarrow$ DPPH-H + Antioksidant ${ }^{\circ}$ (Goupy i sar., 2003). Zbog nesparenog elektrona DPPH ${ }^{\bullet}$ apsorbuje svetlost u vidljivom delu spektra, na talasnoj dužini od $517 \mathrm{~nm}$ (ljubičasta boja). Kada se ovaj elektron spari u prisustvu antioksidanta, apsorbanca na ovoj talasnoj dužini opada (transformacija ljubičaste boje u žutu). Promenjen intenzitet boje srazmeran je broju uhvaćenih (stabilizovanih) radikala. Određivanje kapaciteta neutralizacije $\mathrm{DPPH}^{\bullet}$ radikala je metoda koja je široko prihvaćena i primenjiva zbog dostupnosti $\mathrm{DPPH}^{\bullet}$ radikala, tačnosti, osetljivosti i brzine metode.

Antioksidativna aktivnost je izražena vrednošću $\mathrm{IC}_{50}$ koja predstavlja koncentraciju (mg suvog ekstrakta po $1 \mathrm{ml}$ ) za neutralisanje 50\% DPPH radikala. $\mathrm{IC}_{50}$ vrednosti se dobijaju određivanjem RSC vrednosti na osnovu izmerenih vrednosti apsorbance prema prethodno datoj jednačini (eksperimentalni deo 4.9.), a zatim izračunavanjem iz jednačine linearne regresije. Manja $\mathrm{IC}_{50}$ vrednost ukazuje na veću antioksidativnost.

U tabeli 27 dat je prikaz antioksidativnog potencijala etarskog ulja i pojedinih ekstrakata bosiljka dobijenih pri različitim pritiscima superkritčnog $\mathrm{CO}_{2}$ i konstantnoj temperaturi ekstrakcije.

$\mathrm{IC}_{50}$ vrednosti ispitivanih ekstrakta bosiljka iznose od 18,93 do 136,60 $\mu \mathrm{g} / \mathrm{ml}$. Koncentracija etarskog ulja koja je potrebna da se ostvari 50\% inhibicije DPPH ${ }^{\bullet}$ radikala iznosi 52,92 $\mu \mathrm{g} / \mathrm{ml}$. Na osnovu $\mathrm{IC}_{50}$ vrednosti evidentno je da etarsko ulje i svi ekstrakti poseduju antioksidativnu aktivnost dovodeći do prevođenja stabilnog u neutralni oblik DPPH radikala. 
Tabela 27. Rezultati određivanja antioksidativne aktivnosti etarskog ulja i ekstrakata bosiljka dobijenih sukcesivnom ekstrakcijom (frakcionisanjem) ugljendioksidom na temperaturi od $60^{\circ} \mathrm{C}$ i povećanjem pritiska od 100 do 300 bar

\begin{tabular}{cc}
\hline Uzorak & IC $_{\mathbf{5 0}}(\boldsymbol{\mu g} / \mathbf{m l})$ \\
\hline EO & 52,92 \\
E1 & 18,93 \\
E2 & 113,62 \\
E3 & 117,26 \\
E4 & 136,60 \\
\hline
\end{tabular}

Oznake uzoraka:

EO - Etarsko ulje

$\mathrm{E} 1\left(\mathrm{p}=100 \mathrm{bar}, \mathrm{t}=60^{\circ} \mathrm{C}\right)$

$\mathrm{E} 2\left(\mathrm{p}=150 \mathrm{bar}, \mathrm{t}=60^{\circ} \mathrm{C}\right)$

$\mathrm{E} 3\left(\mathrm{p}=200\right.$ bar, $\left.\mathrm{t}=60^{\circ} \mathrm{C}\right)$

$\mathrm{E} 4\left(\mathrm{p}=300\right.$ bar, $\left.\mathrm{t}=60^{\circ} \mathrm{C}\right)$

Redosled antiradikalske aktivnosti ispitivanih uzoraka na DPPH ${ }^{\bullet}$ je: E1 > Etarsko ulje > E2 $>$ E3 > E4, iz čega se zaključuje da najveću antioksidativnu aktivnost poseduje ekstrakt E1. Antioksidativno dejstvo ekstrakta E1 je oko 5 puta veće od antioksidativne aktivnosti etarskog ulja, a čak do 10 puta veća od aktivnosti ostalih ekstrakata (E2, E3 i E4). Visoka antioksidativna aktivnost ekstrakta E1 se može objasniti pre svega kvalitativnim i kvantitativnim sastavom ekstrakta, kao i velikim sadržajem linaloola u ekstraktu E1, u odnosu na ekstrakte dobijene procesom frakcionisanja na višim pritiscima iz delimično iscrpljene droge. Kako se sadržaj linaloola u dobijenim ekstraktima smanjuje (tabela 28), IC $_{50}$ vrednost se povećava a rezulta je smanjenje antiradikalske aktivnosti. Ovo navodi na zaključak o važnosti linaloola kao najsnažnijem antioksidantu $\mathrm{u}$ ispitivanim uzorcima.

Tabela 28. Sadržaj (g/100 g) dominatnih komponenata u ispitivanim ekstraktima bosiljka

\begin{tabular}{lcccc} 
Komponente & E1 & E2 & E3 & E4 \\
\hline Linalool & 14,15 & 5,14 & 2,04 & 1,22 \\
Eugenol & 11,29 & 5,59 & 6,92 & 1,43 \\
$\alpha$-Bergamoten & 3,50 & 1,70 & 2,01 & 0,40 \\
$\delta$-Kadinen & 7,91 & 5,55 & 6,51 & 1,02 \\
Germakren D & 3,38 & 1,57 & 1,85 & 0,28 \\
Metil-havikol & 0,73 & 0,20 & - & - \\
\hline
\end{tabular}

$\mathrm{Na}$ osnovu literaturnih podataka, komponente etarskog ulja bosiljka kod kojih je najčešće proučavana antioksidativna aktivnost su: linalool, metil-havikol, 1,8-cineol i eugenol. 
Antioksidativna aktivnost eugenola, kao jedne od najzastupljenijih komponenata $\mathrm{u}$ ispitivanim ekstraktima bosiljka dokazana je u in vitro i in vivo uslovima (Nagababu i sar., 2010). Na osnovu prethodno iznetog, može se zaključiti da osim linaloola, ostale komponente prisutne u ekstraktu E1 (eugenol, $\alpha$-bergamoten, metil-havikol, $\delta$-kadinen, germakren D) imaju sinergistički efekat i povećavaju antioksidativno delovanje. 


\section{EKSPERIMENTALNI DEO}

Eksperimentalni rad ove doktorske disertacije je urađen u laboratorijama Katedre za biotehnologiju i farmaceutsko inženjerstvo, Tehnološkog fakulteta Univerziteta u Novom Sadu i SP Laboratorije iz Bečeja.

Biljni materijal. Bosiljak (Ocimum basilicum L.) je plantažno gajen 2011. godine u Bačkom Petrovcu, u Institutu za organsku proizvodnju i biodiverzitet. Osušena herba (list i cvet) je čuvana na sobnoj temperaturi na tamnom i suvom mestu.

\section{Hemikalije}

Svi reagensi i hemikalije upotrebljeni u eksperimentalnom radu bili su analitičke čistoće.

- Metanol, Sigma (Deisenhofen, Nemačka),

- 1,1-difenil-2-pikrilhidrazil (DPPH'), Sigma-Aldricht GmbH (Sternheim, Nemačka),

- Komercijalni ugljendioksid $\left(\mathrm{CO}_{2}\right)$, ( $\left.\geq 99 \%\right)$, Messer Tehnogas, Novi Sad, Srbija,

- Metilen-hlorid, Centrohem, Stara Pazova, Srbija

- Destilovana voda, TKA water purification system tip:05.30C 7-DEN,

- Standardi za GC/FID ((+)-limonen, eukaliptol, linalool, $\alpha$-terpineol, metil-havikol, geraniol) proizvođača Ehrenstorfen (Nemačka) i Carl Roth GmbH (Nemačka)

\section{Aparati i uređaji}

- Ekstrakcija ugljendioksidom u superkritičnom stanju izvršena je u laboratorijskom uređaju (HPEP - High Pressure Extraction Plant, NOVA - Swiss, Effretikon, Switzerland),

- Analitička vaga, Sartorius 2474, Nemačka,

- Vortex mikser, EV - 100, Tehnica, Železniki, Slovenija,

- Mlin za kafu, Bosch, Nemačka,

- Rotavapor, Devarot, Elektromedicina, Ljubljana, Slovenija,

- Spektofotometrijska merenja rađena su na spektofotometru Jenway 6300 VIS, Velika Britanija,

- GC/MS i GC/FID, GC 6890N, Agilent i MS 5795, Agilent, USA. 


\subsection{Određivanje stepena usitnjenosti}

Herba bosiljka se usitni u mlinu za kafu (1200 g). Odmeri se 100 g droge u cilju određivanja srednjeg pričnika čestica i proseje kroz set sita proizvođača ERWEKA (Nemačka). Izmeri se masa droge koja je zaostala na svakom situ nakon prosejavanja, i izračuna srednji prečnik čestica na osnovu sledeće jednačine:

$$
\frac{100}{d}=\sum \frac{m_{i}}{d_{i}}
$$

gde je:

$\mathrm{m}_{\mathrm{i}}$ - maseni procenat i-te frakcije,

$\mathrm{d}_{\mathrm{i}}$ - srednji prečnik i-te frakcije.

Srednji prečnik čestica usitnjenog materijala određen analizom sejanja iznosio je: $\mathrm{d}=0,657 \pm 0,012 \mathrm{~mm}$

\subsection{Određivanje sadržaja vlage}

Sadržaj vlage u biljnom materijalu određen je gravimetrijskim postupkom na osnovu gubitka sušenjem koji propisuje Ph. Jug. IV.

\subsection{Određivanje sadržaja etarskog ulja}

Sadržaja etarskog ulja hidrodestilacijom određen je po Ph. Jug. IV.

\subsection{Određivanje ukupnih ekstraktivnih materija (Soxhlet ekstrakcija)}

$20 \mathrm{~g}$ usitnjene droge se prenese u ekstrakcionu čauru i postavi u telo ekstraktora. Iznad tela ekstraktora postavi se kondenzator. U balon se sipa $130 \mathrm{ml}$ metilen-hlorida (2/3 zapremine balona). Sadržaj balona se zagreva pri čemu pare rastvarača prolaze kroz cev ekstraktora, kondenzuju se u kondenzatoru, vraćaju u telo ekstraktora, i ekstrahuju supstance iz uzorka. Kad se telo ekstraktora napuni rastvaračem, sadržaj se preliva (,sifonira“) preko cevi u balon. Ukupan broj „sifoniranje“ iznosio je 15 puta. Nakon završene ekstrakcije izvršeno je uklanjanje rastvarača iz ekstrakta uparavanjem na rotacionom vakuum uparivaču do suvog ostatka. Na osnovu mase ekstrakta izračuna se prinos ekstrakcije $(\%, \mathrm{~m} / \mathrm{m})$ 


\subsection{Ekstrakcija bosiljka ugljendioksidom u superkritičnom stanju}

Ekstrakcija droge vršena je u laboratorijskom uređaju High Pressure Extraction Plant (HPEP, NOVA - Swiss), čija je šema prikazana na slici 33.

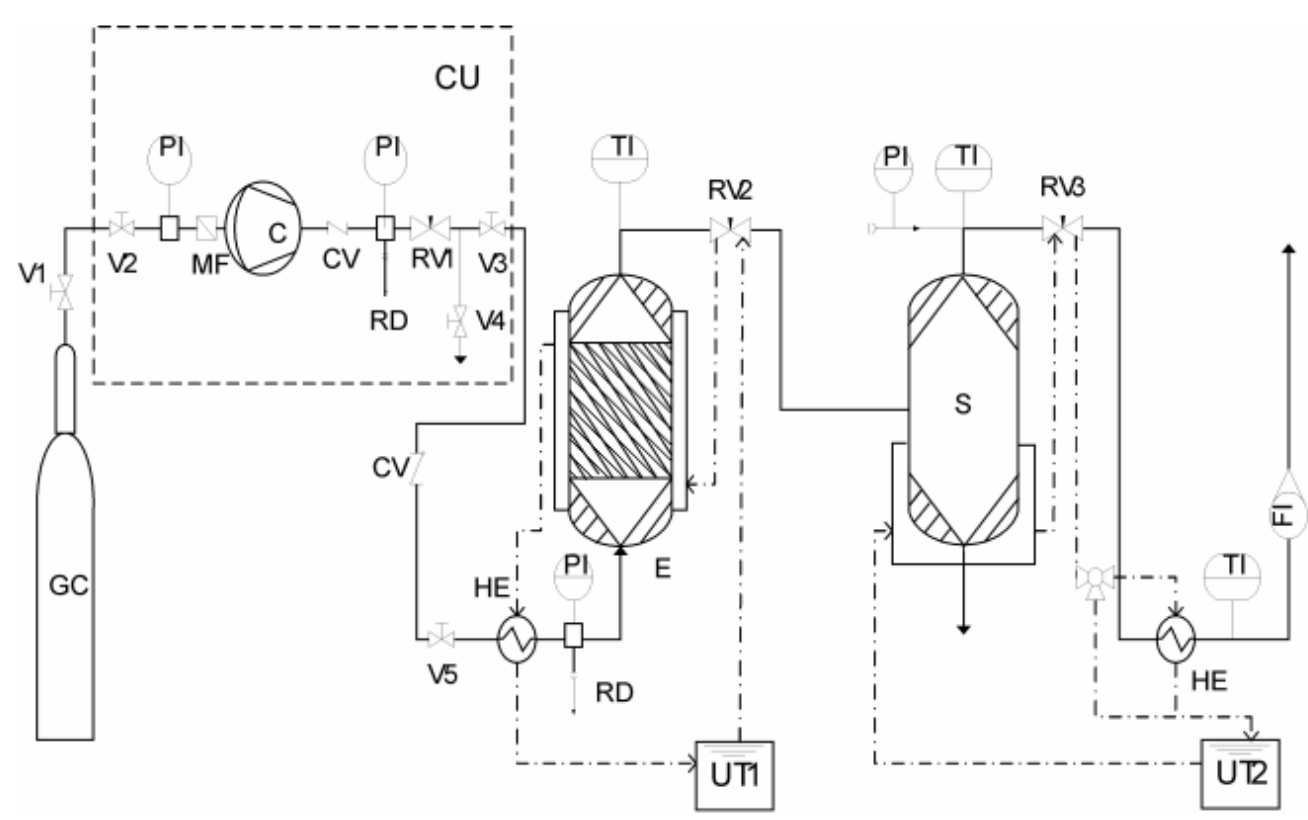

Slika 33. Šema laboratorijskog uređaja za ekstrakciju čvrstog materijala superkritičnim ugljendioksidom

GC-boca sa $\mathrm{CO}_{2}, \mathrm{CU}$-kompresorska jedinica, C-kompresor sa dijafragmom, E-ekstraktor, $S$-separator, HE-izmenjivač toplote, UT-ultratermostat, RV-regulacioni ventil, $V$-ventil, MF-mikrofilter, CV-nepovratni ventil, RD-rupturni disk, PI-merač pritiska, TI-merač temperature, FI-merač protoka.

Odmeri se 50,0 g uzorka i unese u ekstraktor (E) (slika 33). Biljni materijal u ekstraktoru se najpre oslobađa prisutnog vazduha produvavanjem $\mathrm{CO}_{2}$ iz boce (GC) $\mathrm{u}$ gasovitom stanju, nakon čega se zatvore ventil (V5) i regulacioni ventil (RV2). Ultratermostatima (UT1) i (UT2) se održavaju radne temperature u ekstraktoru (E) i separatoru (S) pri zatvorenom ventilu (V1) boce sa $\mathrm{CO}_{2}$. Zatim se, nakon otvaranja ventila od V1 do V5 (V4 je zatvoren), kompresor na kome je podešen pritisak nešto iznad radnog pusti u pogon i regulacionim ventilom (RV1) se podesi radni pritisak. Ugljendioksid se nakon prolaska kroz izmenjivač toplote (HE) otvaranjem ventila (V5) uvodi u ekstraktor, pri čemu je regulacioni ventil (RV2) zatvoren. Otvaranjem i podešavanjem regulacionih ventila (RV2) i (RV3) se ostvaruje željeni pritisak u separatoru, kao i održavanje radnog protoka ekstragensa. 
Ekstrakcioni uslovi su dati u tabeli 29 , a separacioni uslovi su $\mathrm{p}=15$ bar i $\mathrm{t}=25^{\circ} \mathrm{C}$.

Tabela 29. Ekstrakcioni uslovi pri superkritičnoj ekstrakciji bosiljka

\begin{tabular}{|c|c|c|}
\hline $\mathbf{t}\left({ }^{\circ} \mathbf{C}\right)$ & $\mathbf{P}(\mathbf{b a r})$ & $\mathbf{d}\left(\mathbf{k g} / \mathbf{m}^{\mathbf{3}}\right)$ \\
\hline \multirow{4}{*}{40} & 100 & 0,568 \\
\cline { 2 - 3 } & 150 & 0,756 \\
\cline { 2 - 3 } & 200 & 0,831 \\
\cline { 2 - 3 } & 300 & 0,929 \\
\hline \multirow{4}{*}{50} & 100 & 0,378 \\
\cline { 2 - 3 } & 150 & 0,659 \\
\cline { 2 - 3 } & 200 & 0,765 \\
\hline \multirow{4}{*}{60} & 300 & 0,881 \\
\cline { 2 - 3 } & 100 & 0,294 \\
\cline { 2 - 3 } & 150 & 0,563 \\
\cline { 2 - 3 } & 200 & 0,696 \\
\hline
\end{tabular}

U cilju dobijanja ekstrakta bosiljka rađena su dva seta eksperimenata pri navedenim uslovima ekstrakcije.

Prvi set ekstrakcija vršen je u cilju dobijanja totalnog ekstrakta bosiljka. Prinos ekstrakcije praćen je nakon 30, 60, 90, 120, 180 i 240 minuta i protoku ugljendioksida od 3,225 g/min. Ispitane su kombinacije P i t date u tabeli 29.

Drugi set ekstrakcija imao je za cilj frakcionisanje ekstrakata bosiljka iscrpljivanjem droge. Uzorak bosiljka (50,0 g) se prvo ekstrahuje na pritisku od 100 bara i temperaturi od $40^{\circ} \mathrm{C}$ u cilju dobijanja ekstrakta E1 koji se izdvaja. Nakon prve ekstrakcije delimično iscrpljena droga se dalje ekstrahuje ugljen-dioksidom na pritisku 150 bara i temperaturi od $40^{\circ} \mathrm{C}$ u cilju dobijanja ekstrakta E2. Ekstrakcija se sa istom drogom dalje vrši na 200 bara i $40^{\circ} \mathrm{C}$ (ekstrakt E3), a zatim na pritisku od 300 bara i temperaturi od $40^{\circ} \mathrm{C}$ (ekstrakt E4). $\mathrm{Na}$ isti način ekstrakcija bosiljka je vršena i na temperaturama od 50 i $60^{\circ} \mathrm{C}$. Šematski prikaz frakcionisanja superkritičnom ekstrakcijom dat je na slici 34.

Dobijeni ekstrakti bosiljka su preneti u staklene bočice, koje su zatvorene i čuvane u frižideru na temperaturi od $4{ }^{\circ} \mathrm{C}$. 


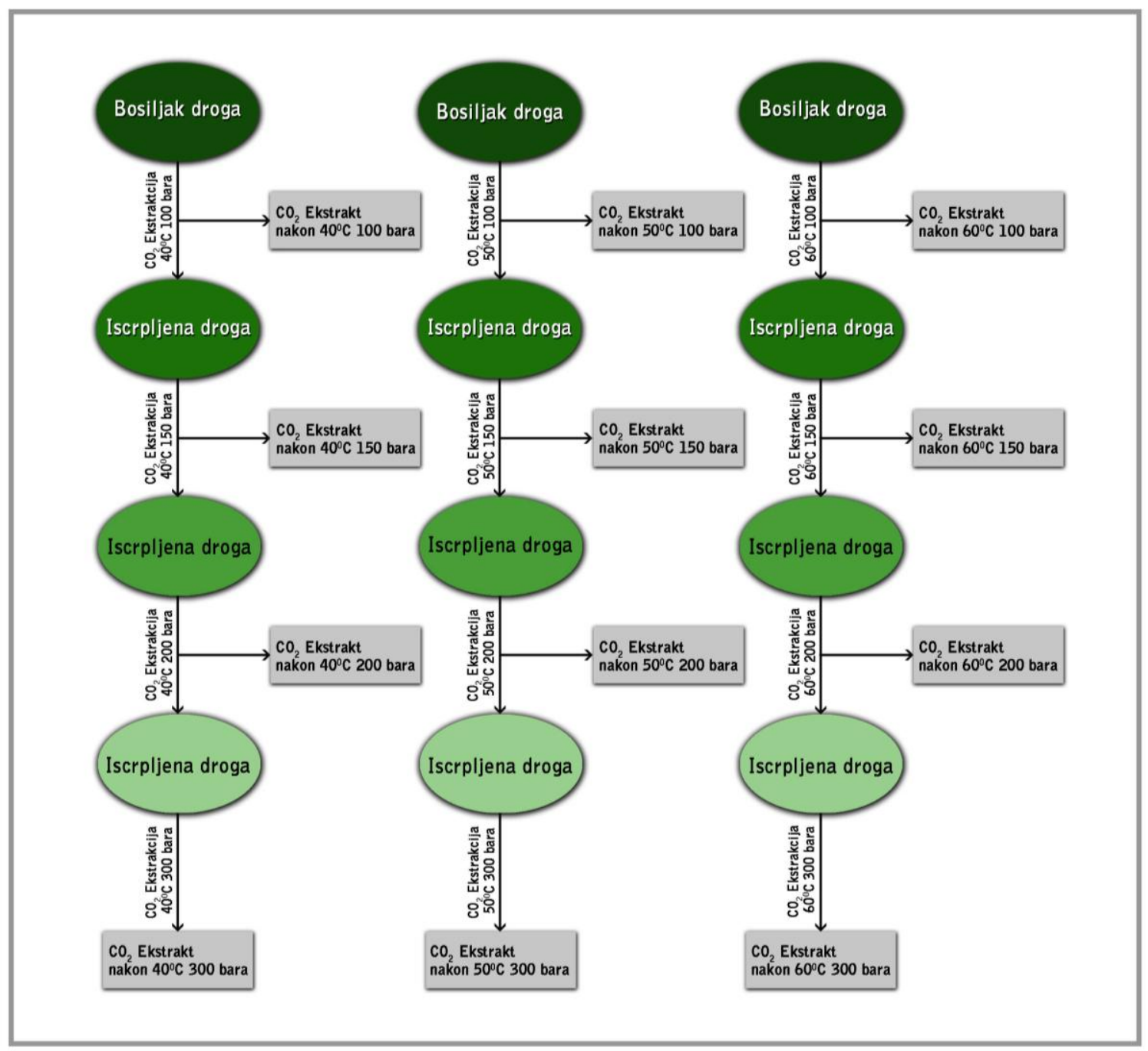

Slika 34. Šema frakcionisanja superkritičnom ekstrakcijom bosiljka

\subsection{Metod odzivne površine}

U cilju dobijanja optimalnih parametara ekstrakcije superkritičnim ugljendioksidom primenjen je Model odzivne površine (Response Surface Methodology - RSM). RSM je skup statističkih i matematičkih modela pogodnih za razvoj, poboljšanje i optimizaciju procesa u kojim karakteristika koja je od važnosti (npr. prinos ekstrakcije) zavisi od nekoliko promenljivih, a krajnji cilj je optimizacija te karakteristike. Ova metoda ima važnu primenu u izradi modela, razvoju i formulaciji novih proizvoda, kao i unapređenju postojećih proizvodnih modela. Ova metoda jasno definiše uticaj nezavisnih promenljivih na proces, samih ili u kombinaciji. 
Optimizaciju pomoću RSM moguće je podeliti u tri faze :

\section{Određivanje nezavisnih parametara i njihovih nivoa}

Kako je nemoguće odrediti uticaj svih parametara, potrebno je odabrati parametre sa najvećim uticajem. Za odabrane parametre vrlo je važno odrediti nivoe ispitivanja, jer je uspeh optimizacije procesa povezan sa njima. Pogrešno odabrani nivoi dovode do neuspešne optimizacije. Kako bi se izvršilo modelovanje procesa realne vrednosti ispitivanih parametara se prevode u kodirane vrednosti koje se dalje koriste u modelovanju.

Opšta jednačina koja se koristi za kodiranje realnih vrednosti parametara ima oblik:

$$
\mathrm{X}=\frac{x-\left[x_{\text {max }}+x_{\text {min }}\right] / 2}{\left[x_{\text {max }}-x_{\text {min }}\right] / 2}
$$

gde su :

$\mathrm{x}$ - prava vrednost promenljive,

$\mathrm{X}$ - kodirana vrednost promenljive,

$\mathrm{x}_{\max }$ - maksimalna vrednost prave vrednosti promenljive $\mathrm{i}$

$\mathrm{x}_{\min }-$ minimalna vrednost prave vrednosti promenljive.

\section{Izbor odgovarajućeg eksperimentalnog modela, predviđanje i provera jednačine modela}

Kompjuterski programski paketi nude optimalni model zasnovan na posebnom kriterijumu i podacima koje unosi korisnik. Ovi modeli se razlikuju jedan od drugog po izboru eksperimentalnih tačaka i broju ponavljanja. Nakon izbora modela, određuje se jednačina modela i regresioni koeficijenti (Bas i sar., 2007). Za oprimizaciju eksperimentalnih podataka u metodi odzivne površine najčešće se koristi model Box-Behnken sa tri promenljive, koji predstavlja kvadratnu jednačinu (ili njen skraćeni oblik):

$$
Y=b_{0}+\sum b_{i} X_{i}+\sum b_{i i} X_{i i}^{2}+\sum b_{i j} X_{i} X_{j}
$$

gde su:

$Y$ - odzivna funkcija,

$b_{0}$ - odsečak.

$b_{i}$ - linearni koeficijent,

$b_{i i}$ - kvadratni koeficijent,

$b_{i j}$ - koeficijent interakcije,

$X_{i}, X_{j}$ - kodirane vrednosti nezavisno promenljivih. 
Nakon određivanja koeficijenata, proračun odziva se dobija pomoću jednačine modela. Pogodnost modela, odnosno provera da li model odgovara eksperimentalnim rezultatima, obično se tumači na osnovu koeficijenta determinacije $\left(\mathrm{R}^{2}\right)$, koji je mera odstupanja odzivne funkcije od eksperimentalno dobijenih rezultata.

\section{Grafičko prikazivanje jednačine modela i određivanje optimalnih radnih uslova}

Jednačina modela grafički može biti prikazana na dva načina, u dve ili tri dimenzije. Trodimenzionalni dijagram se naziva odzivna površina $i$ on pokazuje povezanost odziva $i$ nezavisno promenljivih. Dvodimenzionalni dijagram, u obliku kontura, daje dobru sliku oblika odzivne površine. Kada ovaj dijagram pokaže elipsu ili krug, centar sistema daje maksimum ili minimum odziva. Ukoliko dijagram pokaže hiperbolu ili parabolu, fiksna tačka se naziva prevojna tačka i ona nije ni minimum ni maksimum.

Fiksna tačka (minimalna ili maksimalna) je tačka u kojoj je prvi izvod date funkcije jednak nuli:

$Y=f\left(X_{1}, X_{2}, X_{3}\right)=b_{0}+b_{1} X_{1}+b_{2} X_{2}+b_{3} X_{3}+b_{11} X_{1}^{2}+b_{22} X_{2}^{2}+b_{33} X_{3}^{2}+b_{12} X_{1} X_{2}+b_{13} X_{1} X_{3}$

$+b_{23} X_{2} X_{3}$

Izračunate vrednosti $\mathrm{X}_{1}, \mathrm{X}_{2}, \mathrm{X}_{3}$ označavaju kodirane vrednosti nezavisnih promenljivih koje daju najveći i najmanji odziv (Bas i sar., 2007).

Sve vrednosti nezavisno promenljivih u ovom radu ispitivane su na 3 nivoa $(-1,0,+1)$, a njihove kodirane i nekodirane vrednosti date su u tabeli 30.

Tabela 30. Kodirane i nekodirane vrednosti nivoa nezavisno promenljivih

\begin{tabular}{|l|c|c|c|c|}
\hline Nezavisne promenljive & Simbol & \multicolumn{3}{c|}{ Nivoi } \\
\hline \multicolumn{2}{|c|}{} & $(-1)$ & 0 & 1 \\
\hline Pritisak (bar) & $\mathrm{X}_{1}$ & 100 & 200 & 300 \\
\hline Temperatura $\left({ }^{\circ} \mathrm{C}\right)$ & $\mathrm{X}_{2}$ & 40 & 50 & 60 \\
\hline
\end{tabular}

Ispitana su dva procesna parametra: pritisak i temperatura.

Statistička obrada eksperimentalnih podataka urađena je komercijalnim programom Design-Expert v.7 Trial (Stat-Ease, Minneapolis, Minnesota, USA). Analiza varijanse (ANOVA) je primenjena pri obradi podataka sa kriterijumom da je stepen pouzdanosti 95,0\%. 


\subsection{Analiza $\mathrm{CO}_{2}$ ekstrakta bosiljka primenom GC-MS(FID)}

Analiza svih dobijenih uzoraka izvršena je pomoću GC/MS i GC/FID hromatografije. Za razdvajanje komponenti korišćen je gasni hromatograf GC 9890N, Agilent, opremeljen split/splitless injektorom, HP-5MS kapilarnom kolonom (dužine $30 \mathrm{~m}$, unutrašnjeg prečnika $0,25 \mathrm{~mm}$, debljine filma $0,25 \mu \mathrm{m})$. Kvantifikacija supstanci izvršena je na osnovu standarda (limonen, eukaliptol, linalool, $\alpha$-terpineol, metil-havikol, geraniol). Uzorci i rastvori referentnih standardnih supstanci su injektovani u zapremini od $5 \mu$, pri split odnosu 1:30.

Kvantifikacija organskih komponenata je urađena pomoću plameno-jonizujućeg detektora (FID), korišćenjem kalibracionog dijagrama za svaku pojedinačnu komponentu. Standardne supstance su rastvorene u metanolu pri čemu je dobijena serija rastvora koncentracije od 1 do $500 \mu \mathrm{g} / \mathrm{ml}$. Minimalni koeficijent korelacije iznosio je 0,99.

Uslovi rada GC/MS instrumenta su sledeći:

Temperatura injektora je $250^{\circ} \mathrm{C}$, linearni temperaturni režim od $60^{\circ} \mathrm{C}$ do $150^{\circ} \mathrm{C}\left(4^{\circ} \mathrm{C} / \mathrm{min}\right)$. Kao gas nosač korišćen je He ( $2 \mathrm{ml} / \mathrm{min})$.

Uslovi rada GC/FID instrumenta su sledeći:

Temperatura injektora iznosila je $250^{\circ} \mathrm{C}$. Linearni temperaturni režim od $60^{\circ} \mathrm{C}$ do $150^{\circ} \mathrm{C}$ $\left(4^{\circ} \mathrm{C} / \mathrm{min}\right)$, dok je temperatura detektora iznosila $300^{\circ} \mathrm{C}$.

Identifikacija organskih komponenti rađena je pomoću masenog spektometra MS 5795, Agilent, poređenjem masenog spektra jedinjenja dobijenog iz uzorka, na odgovarajućem retencionom vremenu i masenog spektra iz baze podataka masenih spektara. Korišćene su biblioteke sa podacima masenih spektara Wiley 7n i NIST 05.

\subsection{Matematičko modelovanje kinetike ekstrakcije bosiljka superkritičnim $\mathrm{CO}_{2}$}

Za opisivanje kinetike ekstrakcije bosiljka superkritičnim ugljen-dioksidom ispitana je primenjivost sledećih matematičkih modela:

$>$ Kandiah i Spiro (1990),

$>$ Brunner (1984),

$>$ Esquivel i sar. (1999).

Uspešnost aproksimacije eksperimentalnih podataka ekstrakcije odabranim matematičkim modelom procenjena je na osnovu srednje vrednosti relativnog odstupanja (engl. Average Absolute Relative Deviation - AARD) izračunatih vrednosti pomoću modela $\left(\mathrm{Y}_{\mathrm{izr}, \mathrm{i}}\right)$ i eksperimentalno određenih vrednosti $\left(\mathrm{Y}_{\mathrm{eks}, \mathrm{i}}\right)$ : 
$\mathrm{AARD}=\frac{1}{n} \cdot \sum_{i=1}^{n}\left|\frac{Y_{e k s, i}-Y_{i z r, i}}{Y_{e k s, i}}\right| \cdot 100$

gde je:

n broj eksperimenata.

\subsection{Određivanje antioksidativne aktivnosti DPPH metodom}

Određivanje sposobnosti neutralizacije $\mathrm{DPPH}^{\bullet}$ (1,1-difenil-2-pikrilhidrazil) radikala urađeno je primenom spektofotometrijske metode (Espin i sar., 2000) koja je zasnovana na praćenju promene boje ljubičasto obojenog rastvora stabilnog $\mathrm{DPPH}^{\bullet}$ radikala u redukovanu, žuto obojenu formu, DPPH-H (slika 35). Kapacitet „hvatanja“ slobodnih radikala, odnosno „skevindžer“ aktivnost (RSC, Radical Scavengig Capacity) ispitivanih ekstrakata određen je merenjem njihove sposobnosti da neutrališu $\mathrm{DPPH}$ radikale, a zatim je određena $\mathrm{IC}_{50}$ vrednost (koncentracija ispitivane supstance pri kojoj je neutralisano 50\% radikala).

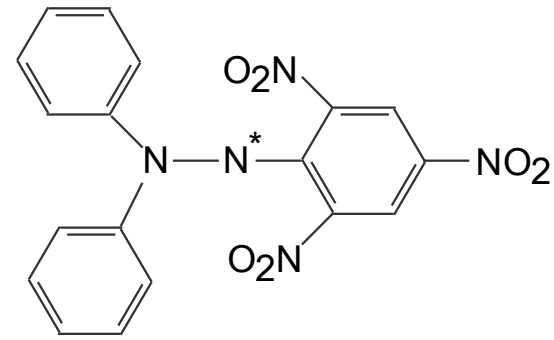

$\mathrm{DPPH}^{\bullet}$ radikal (ljubičast)

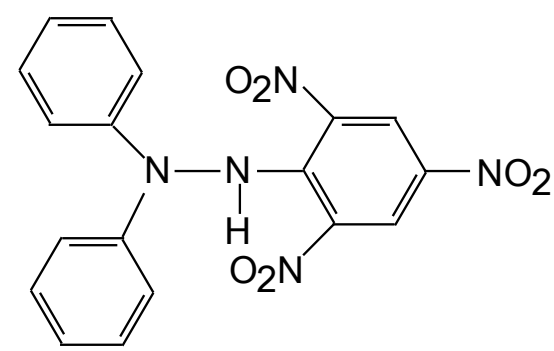

DPPH-H (̌̌ut)

Slika 35. Radikalska i redukovana forma DPPH

Slobodni $\mathrm{DPPH}^{\bullet}$ radikal reaguje sa antioksidativnom komponentom, koja je donor vodonikovih atoma, pri čemu dolazi do redukcije (nastaje DPPH-H forma), odnosno ljubičasto obojeni stabilni $\mathrm{DPPH}^{\bullet}$ radikal se transformiše u žuto obojenu neutralnu formu DPPH-H. Promena intenziteta boje je proporcionalna broju uhvaćenih radikala.

Postupak: Ekstrakt bosiljka se rastvori u 95\% metanolu do koncentracije od $1 \mathrm{mg} / \mathrm{ml}$. U kiveti se pomešaju određene zapremine metanolnog rastvora ekstrakta $(80-800 \mu \mathrm{l}) \mathrm{sa} 1 \mathrm{ml}$ $90 \mu \mathrm{mol} / \mathrm{dm}^{3}$ rastvora $\mathrm{DPPH}^{*}$ radikala i dopuni $95 \%$ metanolom do $4 \mathrm{ml}$. Na ovaj način se dobijaju pet različitih koncentracija ekstrakta bosiljka $(0,01 ; 0,02 ; 0,05 ; 0,1$ i $0,2 \mathrm{mg} / \mathrm{ml})$. Kontrolni uzorak predstavlja smešu u kojoj je umesto ekstrakta dodata destilovana voda. Kao 
slepa proba koristi se 95\% metanol. Nakon inkubacije od 60 min na sobnoj temperaturi izmeri se apsorbanca reakcione smeše na talasnoj dužini od $515 \mathrm{~nm}$.

Antioksidativna aktivnost određena primenom ove metode izražava se preko RSC vrednosti (kapacitet „hvatanja“ radikala, ili Radical Scavengig Capacity), koja se izračunava primenom jednačine:

$$
\operatorname{RSC}(\%)=100-\frac{A u z \cdot 100}{A s p}
$$

gde su:

$A u z$ - apsorbanca uzorka,

Asp - apsorbanca slepe probe.

$\mathrm{IC}_{50}$ vrednost $(\mathrm{mg} / \mathrm{ml})$, definisana kao koncentracija ekstrakta potrebna da reagije sa $50 \% \mathrm{DPPH}^{\circ}$ radikala $(\mathrm{RSC}=50 \%)$ u uslovima koje definiše metoda, dobijena je računski iz jednačine linearne regresije. 


\section{ZAKLJUČCI}

U okviru ove doktorske teze izvršena su ispitivanja ekstrakcije bosiljka (Ocimum basilicum L.), hemijskog sastava, antioksidativnog delovanja dobijenih ekstrakata i modelovanja ekstrakcionog sistema primenom matematičkih model jednačina. Na osnovu dobijenih rezultata mogu se izvesti sledeći zaključci:

1. Hidrodestilacijom bosiljka određen je sadržaj etarskog ulja koji iznosi $0,565 \%$, i nalazi se u granicama koje navodi literatura. Kvalitativni i kvantitativni sastav etarskog ulja određivan je GC/MS i GC/FID metodom. Identifikovano je 25 komponenata koje su grupisane u pet grupa: monoterpenski ugljovodonici (1,26\%), oksidovani monoterpeni (55,84\%), aromatični oksidovani monoterpeni (7,06\%), seskviterpenski ugljovodonici $(30,77 \%)$ i oksidovani seskviterpeni $(0,73 \%)$. Na osnovu dobijenih rezultata kvalitativne i kvantitativne GC-MS analize može se zaključiti da je dominantno jedinjenje u etarskom ulju bosiljka linalool sa relativnim udelom 50,09\% (GC-MS), odnosno sa sadržajem u etarskom ulju od 49,79\% (m/m) (GC-FID) i prinosom 281,31 mg/100 g droge. Ostale komponente koje se nalaze u većem procentu od $3 \%$ su $\delta$-kadinen $8,12 \%$ (odnosno $8,07 \%(\mathrm{~m} / \mathrm{m})$ ), germakren $5,76 \%$ (odnosno 5,73\% (m/m)), $\alpha$-bergamoten 4,14\% $(4,11 \%(\mathrm{~m} / \mathrm{m})$ ), eugenol 3,76\% $(3,74 \%$ $(\mathrm{m} / \mathrm{m}), \beta$-selinen 3,58\% $(3,56 \%(\mathrm{~m} / \mathrm{m}))$ i metil-havikol 3,30\% (odnosno 3,38\% (m/m)).

2. Rezultati ispitivanja hemijskog sastava etarskog ulja Ocimum basilicum L. pokazuju da ono pripada linaloolskom hemotipu (hemotip A) koji je karakterističan za Evropsko područje, a karakteriše se najboljim kvalitetom i aromom.

3. Ekstrakcija bosiljka metilen-hloridom uz povremeno ispuštanje ekstrakta (Soxhlet ekstrakcija) dala je prinos od $1,950 \%(\mathrm{~m} / \mathrm{m})$, što je za oko tri puta više u odnosu na sadržaj etarskog ulja u bosiljku. Kvalitativnom i kvantitativnom GC/MS analizom metilen-hloridnog totalnog ekstrakta detektovano je 15 komponenata (sa udelom od 48,12\%). Sadržaj dominantne komponente linaloola je znatno manji nego u etarskom ulju bosiljka i iznosi svega 11,46\% (GC/MS) (kvantitativni sadržaj 2,56 \% (m/m) određen GC/FID) odnosno prinos ekstrakcije je 49,92 mg/100 g droge. Rezultati hromatografske analize totalnog ekstrakta pokazuju da se ovim postupkom ekstrakcije, osim etarskog ulja ekstrahuju i sve komponente koje nisu u sastavu etarskog ulja (sa udelom od 51,91\%).

4. Superkritičnom ekstrakcijom bosiljka na temperaturama od 40,50 i $60^{\circ} \mathrm{C}$ i pritiscima od 100, 150, 200 i 300 bara, pri protoku $\mathrm{CO}_{2}$ od 3,225 g/min, veličini čestica od $0,657 \mathrm{~mm} \mathrm{i}$ vremenskom trajanju od $4 \mathrm{~h}$, prinosi dobijenih totalnih ekstrakata kretali su se od 0,382 do 
$1,879 \%$. Utvrđeno je da ukupni prinosi pri izotermnoj ekstrakciji rastu, sa porastom pritiska ekstrakcije, zbog povećanja gustine $\mathrm{CO}_{2}$, odnosno rastvorne moći $\mathrm{CO}_{2}$ kao ekstragensa. Sa povećanjem radne temperature ekstrakcije može se uočiti da se prinos ekstrakcije takođe povećava, što se može objasniti povećanjem rastvorljivosti komponenata u superkritičnom fluidu sa povećanjem temperature ekstrakcije. Najveći prinos ekstrakcije je ostvaren na temperaturi od $60^{\circ} \mathrm{C}$ i pritisku od 300 bar, i iznosi $1,879 \%$.

4. Sukcesivnom (frakcionom) superkritičnom ekstrakcijom pri istim radnim uslovima ekstrakcije ( $p=100,150,200$ i 300 bar, $t=40,50$ i $60^{\circ} \mathrm{C}, \tau=4$ h) praćeni su prinosi $\mathrm{i}$ kinetika ekstrakcije. Prinosi dobijenih ekstrakata kretali su se od 0,138 do 1,008\%. Na osnovu dobijenih rezultata tokom frakcionisanja najveći prinos postiže se pri pritisku od 100 bara i $40^{\circ} \mathrm{C}$ i iznosi $0,693 \%$, i 100 bara i $50^{\circ} \mathrm{C}$ u iznosu od $1,008 \%$, odnosno u prvoj fazi frakcione ekstrakcije.

5. Primenom GC/MS i GC/FID metode izvršena je kvalitativna i kvantitativna analiza totalnih $\mathrm{CO}_{2}$ ekstrakata i pojedinačnih frakcija. U dobijenim ekstraktima bosiljka dominatne su sledeće komponente: linalool, eugenol i $\delta$-kadinen. Ostale komponente koje su imale sadržaj iznad 2\% su: $\alpha$-bergamoten, germakren D, $\gamma$-kadinen, $\delta$-kadinen $\beta$-selinen i spatulenol. Najveći sadržaj linaloola (16,6\%) pri jednostepenoj ekstrakciji određen je u ekstraktu 100 bar, $40^{\circ} \mathrm{C}$, ali najveća količina linaloola koja je ekstrahovana iz $100 \mathrm{~g}$ droge nije dobijena pri ovim ekstrakcionim uslovima. Najveći prinos linaloola je dobijen primenom pritiska od 200 bar na $40^{\circ} \mathrm{C}$, odnosno gustine $\mathrm{CO}_{2} 0,831 \mathrm{~kg} / \mathrm{m}^{3}$ i iznosi $199,75 \mathrm{mg} / 100 \mathrm{~g}$ droge. Najveći prinos eugenola od 123,29 mg/100 g droge je određen u totalnom ekstraktu 150 bar, $60^{\circ} \mathrm{C}$, dok je najveći prinos $\delta$-kadinena određen u ekstraktu $150 \mathrm{bar}, 50^{\circ} \mathrm{C}(91,79 \mathrm{mg} / 100 \mathrm{~g}$ droge $)$.

6. Utvrđeno je da se frakcionisanjem lipofilnih komponenata procenat identifikovanih komponenata smanjuje sa povećanjem pritiska, pri konstantnoj temperaturi sa iscrpljivanjem droge, dok se procenat neidentifikovanih komponenata u ekstraktima povećava. Ovo navodi na zakljičak da se sa povećenjem pritiska tj. gustine ekstragensa, pri konstantnoj temperaturi, smanjuje udeo lako isparljivih nepolarnih komponenata (komponente etarskog ulja), a povećava udeo ostalih komponenata veće molekulske mase (voskovi, masna ulja, fitosteroli i sl.) koji se ekstrahuju na većim pritiscima.

Frakciona superkritična ekstrakcija omogućuje da se odabirom ekstrakcionih uslova: temperature, pritiska, odnosno gustine ekstragensa može uticati na selektivnost superkritične ekstrakcije, a samim tim i na sastav dobijenog ekstrakta, čime se omogućava kreiranje novih prirodnih proizvoda na bazi bosiljka, prema željenoj nameni. 
7. Primenom Metode odzivne površine (Response Surface Methodology - RSM) izvršena je optimizacija parametara ekstrakcije. Najveći prinos ekstrakcije ostvaruje se pri pritisku 297 bar i temperaturi od $59,2^{\circ} \mathrm{C}$. Matematički model predviđa da će vrednost prinosa ekstrakcije ( $\mathrm{Y}_{\mathrm{pred}}$ ) izvedene pri navedenim uslovima biti 1,91\%, odnosno da će interval poverenja za eksperimentalno dobijenu vrednost sa $95 \%$ sigurnosti biti od 1,52 do $2,29 \%$. S obzirom da su najveći prinosi ekstrakcije eksperimentalno dobijeni pri sličnim uslovima (300 bar i $60^{\circ} \mathrm{C}$ ), kao i da se prevojna tačka nalazi u tom intervalu, može se zaključiti da primenjeni model u potpunosti odgovara eksperimentalnim uslovima.

8. U cilju definisanja ekstrakcionih parametara (temperature i pritiska) pri kojima bi prinos linaloola (g/100 g ekstrakta) bio najveći, optimizacija je izvršena linearnim modelom. Ovaj model relativno dobro opisuje ispitivani sistem $(p<0,05)$, ali ipak nešto niža vrednost koeficijenta determinacije $\left(R^{2}=0,85\right)$ ukazuje na izvesne nedostatke. Međutim, s obzirom da je najveća eksperimentalna vrednosta za prinos linaloola dobijena na najnižim nivoima pritiska $i$ temperature $\left(100\right.$ bar i $\left.40^{\circ} \mathrm{C}\right)$, za očekivati je da optimalni parametri budu u blizini ovih vrednosti.

9. Za opisivanje kinetike superkritične ekstrakcije u ovom radu ispitana su tri modela (Kandiah i Spiro, Brunner i Esquivel i sar.). Na osnovu vrednosti relativnog odstupanja (oko 8\%) može se zaključiti da je prihvatljivo fitovanje eksperimentalnih podataka i modela koji su dali Kandiah i Spiro u slučaju ekstrakcije bosiljka na nižim pritiscima i nižoj temperaturi. Ostala dva modela pokazuju lošije slaganje eksperimentalno određenih i modelom izračunatih prinosa ekstrakta.

10. Antioksidativna aktivnost etarskog ulja i ekstrakata dobijenih sukcesivnom ekstrakcijom (frakcionisanjem) ugljendioksidom na temperaturi od $60^{\circ} \mathrm{C}$ i povećanjem pritiska od 100 do 300 bar, određene DPPH metodom, pokazala je da se $\mathrm{IC}_{50}$ ispitivanih uzoraka kreće od 18,93 do 136,60 $\mu \mathrm{g} / \mathrm{ml}$. Najveću antioksidativnu aktivnost ima ekstrakt 100 bar, $60^{\circ} \mathrm{C}$, koja je oko 5 puta veće od antioksidativne aktivnosti etarskog ulja, a čak do 10 puta veća od aktivnosti ostalih ispitivanih ekstrakata. Visoka antioksidativna aktivnost ovog ekstrakta se može objasniti pre svega kvalitativnim i kvantitativnim sastavom ekstrakta, kao i velikim sadržajem linaloola $(92,96 \mathrm{mg} / 100 \mathrm{~g})$. Ovo navodi na zaključak o važnosti linaloola kao najsnažnijem antioksidantu u ispitivanim ekstraktima, iako i ostale komponente prisutne $\mathrm{u}$ ekstraktu (eugenol, $\alpha$-bergamoten, metal-havikol, $\delta$-kadinen, germakren D) imaju sinergistički efekat i povećavaju antioksidativno delovanje. 


\section{LITERATURA}

1. Akgerman, A., Madras, G. (1994). Fundamentals of solid extraction by supercritical fluids. In: „Supercritical Fluids. Fundamentals and Application“, Kiran E. and Levelt Sengers J.M.H., Eds., Kluwer, Dordrecht, The Netherlands, pp 669-695.

2. Babović, N., Djilas, S., Jadranin, M., Vajs, V., Ivanović, J., Petrović, S. (2009). Supercritical carbon dioxide extraction of antioxidant fractions from selected Lamiaceae herbs and their antioxidant capacity. Innovative Food Science and Emerging Technologies, 11(1):98-107.

3. Baratta, M.T., Dorman, H.J.D., Deans, S.G., Figueiredo, A.C., Baroso, J.G., Ruberto, G. (1998). Antimicrobial and antioxidant properties of some comercial essential oils. Flavour Fragrance J., 13, 235-244.

4. Barjaktarović, B., Sovilj, M., Knez, Z. (2005). Chemical composition of Juniperus communis L. fruits supercritical $\mathrm{CO}_{2}$ extracts: dependence on pressure and extraction time. J. Agric. Food Chem., 53, 2630-2636.

5. Bas, D., Boyaci, I.H. (2007). Modeling and optimization I: usability of response surface methodology. Journal of Food Engineering, 78, 836-845.

6. Bevan, C.D. and Marshall, P.S. (1994). The use of supercritical fluids in the isolation of natural products. Natural Product Reports, 11,451-456.

7. Bimakr, M. Rahman, R.A., Taip, F.S., Chuan, L.T., Ganjloo, A., Selamat, J., Hamid, A. (2009). Supercritical carbon dioxide $\left(\mathrm{SC}-\mathrm{CO}_{2}\right)$ extraction of bioactive flavonoid compounds from spearmint (Mentha Spicata L.) leaves. Eur. J. Sci. Res., 33, 679-690.

8. Brunner, G. (1984). Mass transfer from sold material in gas extraction. Berichte Bunsengesellschaft fuer Physikalische Chemie, 88, 887-891.

9. Buhler, D.R., Miranda, C. (2000). Antioxidant Activities of Flavonoids. Oregon State University: The Linus Pauling Institute.

10. Catchpole, O.J., Grey, J.B. (1996). Near-Critical Extraction of Sage, Celery and Coriander Seed. The Journal of Supercritical Fluids, 9, 273-279.

11. Cavero, S., García-Risco, M.R., Marín, F.R., Jaime, L., Santoyo, S., Señoráns, F.J., Reglero, G., Ibañez, E. (2006). Supercritical fluid extraction of antioxidant compounds from oregano. Chemical and functional characterization via LC-MS and in vitro assays. J. Supercrit. Fluids, 38, 62-69. 
12. Celiktas, O.Y., Bedir, E., Sukan, F.V. (2007). In vitro antioxidant activities of Rosmarinus officinalis extract treated with supercritical carbon dioxide. Food Chemistry, 10, 14571464.

13. Chang, C.J., Chiu, K., Chen, Y., Chang, C.Y. (2000). Separation of catechins from green tea using carbon dioxide extraction. Food Chemistry, 68, 109-113.

14. Cuvelier, M.E, Richard, H, Berset, C. (1992). Comparison of the antioxidative activity of some acid-phenols: structure-activity relationship. Biosci. Biotech. Biochem., 56:324-325.

15. Cygnarowicz-Provost, M., O’Brien, D.J., Maxwell, R.J., Hampson, J.W. (1992). Supercritical-fluid extraction of fungal lipids using mixed solvents: experiment and modeling. The Journal of Supercritical Fluids, 5, 24-30.

16. Dallmeier, K., Carlini, E.A. (1981). Anesthetic, hypotermic, myorelaxant and anticolvulsant effects of synthetic eugenol derivatives and natural analogues. Pharmacology, 22, 113-127.

17. Darrah, H.H. (1980). The Cultivated Basils. Buckeye Printing Independence, MO.

18. del Valle, J.M., de la Fuente, J.C. (2006). Supercritical $\mathrm{CO}_{2}$ extraction of oilseeds: Rewiev of kinetic and equilibrium models. Critical Reviews in Food Science and Nutrition, 46, 131-160.

19. del Valle, J.M., Napolitano, P., Fuentes, N. (2000). Estimation of relevant mass transfer parameters for the extraction of packed supstrate beds using supercritical fluids. Industrial \& Engineering Chemistry Resarch, 39, 4720-4728.

20. Diaz, M.S., Brignole, E.A. (2009). Modeling and optimization of supercritical fluid processs. The Journal of Supercritical Fluids, 47, 611-618.

21. Duarte, C., Moldão-Martinez, M., Gouveia, A.F., Beirão da Costa, S., Leitão, A.E., Bernardo-Gil M.G. (2004). Supercritical fluid extraction of reed pepper (Capsicum frutescens L.). Journal of Supercritical Fluids, 30, 155-161.

22. Đarmati, Z., Jankov, R.M., Schwirtlich, E., Đulinac, B., Đorđević, A. (1991). High Antioxidant Activity of Extracts Obtained from Sage by Supercritical $\mathrm{CO}_{2}$ Extraction, JAOCS, 68 (10), 731-734.

23. Eller, F.J., Mose,r J.K., Kenar, J.A., Taylor, S.L. (2010). Extraction and analysis of Tomato seed oil. J. American oil Chemists Society, 87, 755-762.

24. Erler, F., Ulug, I., Yalcinkaya, B. (2006). Repellent activity of five essential oils against Culex pipiens. Fitoterapia, 77, (7-8), 491-494. 
25. Espin, J.C., Soler-Rivas, C., Wichers H.J. (2000). Characterization of total free radical scavenger capacity of vegetable oils and oil fractions using 2,2-diphenyl-1-picrylhydrazyl radical. Journal of Agricultural Food Chemistry, 48, 648-656.

26. Esquivel, M.M., Bernardo-Gil, M.G., King, M.B., (1999). Mathematical models for supercritical extraction of olive husk oil. The Jurnal of Supercritical Fluids, 16, 43-58.

27. Fang, Y.Z., Yang, S., Wu, G. (2002). Free Radicals, antioxidants and nutrition. Nutrition, $18,872-879$.

28. Filip, S., Vidović, S., Adamović, D., Zeković, Z. (2014). Fractionation of non-polar compounds of basil (Ocimum basilicum L.) by supercritical fluid extraction (SFE). The Journal of Supercritical Fluids, 86, 85-90.

29. Fleisgher, A. (1981). Essential oils from two varieties of Ocimum basilicum L. grown in Israel. J. Sci. Food Agric. 32:1119-1122.

30. Gelmez, N., Kincal, N.S., Yener, M.E. (2009). Optimization of supercritical carbon dioxide extraction of antioxidants from roasted wheat germ based on yield, total phenolic and tocopherol contents, and antioxidant activities of the extracts. J. Supercrit. Fluids, 48, 217224.

31. Goli, A. H., Barzegar, M., Sahari, M.A. (2005). Antioxidant activity and total phenolic compounds of pistachio (Pistachia vera) hull extracts. Food Chemistry, 92, 521-525.

32. Goto, M., Roy, B.C., Hirose, T. (1996). Shrinking-Core Leaching Model for Supercritical Fluid Extraction. The Journal of Supercritical Fluids, 9, 128-133.

33. Goto, M., Sato, M., Hirose, T. (1993). Extraction of peppermint oil by supercritical carbon dioxide. Journal of Chemical Engineering of Japan, 26, 401-407.

34. Goto, M., Smith, J.M., McCoy, B.J. (1990). Kinetics and Mass Transfer for Supercritical Fluid Extraction of Wood. Industrial and Engineering Chemistry Research, 29, 282-289.

35. Goupy, P., Dufour, C., Loonis, M., Dangles, O. (2003). Quantitative Kinetic Analysis of Hydrogen Transfer Reaction from Dietary Polyphenols to the DPPH Radical. Journal of Agricultural and Food Chemistry, 51,615-622.

36. Grayer, R.J., Kite, G.C., Veitch, N.C., Eckert, M.R., Marin, P.D., Senanayake, P., Paton, A.J. (2002). Leaf flavonoid glycosides as chemosystematic characters in Ocimum. Biochemical Systematics and Ecology, 30, 327-342.

37. Grayer, R.J., Vieira, R.F., Price, A.M., Kite, G.C., Simon, J.E., Paton, A.J. (2004). Characterization of cultivars within species of Ocimum by exudate flavonoid profiles. Biochemical Systematics and Ecology, 32, 901-913. 
38. Guenther, E. (1949). The essential oils. VIII. Robert E. Krieger Publ. Co. Malabar, Florida, p. 399-433.

39. Halliwell, B., Murcia, M.A., Chirico, S., Aruoma O. I. (1995). Free radicals and antioxidants in food and in vivo: What they do and how they work. Critical Reviews in Food Science and Nutrition, 35, 7-20.

40. Harborne, J.B., Baxter, H., Moss, G.P. (Eds.) (1999). Phytochemical Dictionary, A Hand Book of Bioactive compounds from plants. Taylor and Francis Ltd, London, UK.

41. Heim, K.E., Tagliaferro, A.R, Bobilya, D.J. (2002). Flavonoid antioxidants: chemistry. Metabolism and structure-activity relationships. Journal Nutrition Biochemistry, 13, 572584.

42. Herrmann, K. (1989). Occurrence and content of hidroxycinnamic and hydroxybenzoic acid compounds in foods. Critical Review in Food Science Nutrition, 28, 315-347.

43. Hortaçsu, Ö. (2000). Modeling of natural materials extraction „Supercritical Fluids: Fundamentals and Application“. Kiran, E. Debenedetti, P.G., and Peters, C.J., Eds., Kluwer, Dordrecht, The Netherlands, pp. 499-516.

44. Jančić, R. (2004). Botanika farmaceutika, drugo dopunjeno izdanje, Beograd.

45. Javanmardi, J., Khalighi, A., Kashi, A., Bais, H:P.,Vivanco, J.M. (2002). Chemical characterization of basil (Ocimum basilicum L.) found in local accessions and use in tradicional medicines in Iran. J. Agric. Food Chem., 50, 5878-5883.

46. Jayasinghe, C., Gotoh, N., Aoki, T., Wada, S. (2003). Phenolics composition and antioxidant activity of sweet basil (Ocimum basilicum L.). J. Agric. Food Chem., 51, 4442-4449.

47. Jirovetz, L., Buchbauer, G., Shafi, M.P., Kaniampadi, M.M. (2003). Chemotaxonomical analysis of the essential oil aroma compounds of four different Ocimum species from southern India. Europ. Food Res. and Tech., 217 (2), 120-124.

48. Jokić, S. (2011). Matematičko modeliranje ekstrakcije ulja iz zrna soje superkritičnim $\mathrm{CO}_{2}$. Doktorska disertacija. Prehrambeno-Tehnološki fakultet Osijek, Sveučilište Josipa Jurja Strossmayera u Osjeku, Osijek .

49. Jokić, S., Svilović, S., Zeković, Z., Vidović, S. (2011). Mathematical modeling of soybean oil solubility in supercritical carbon dioxide. International Journal of Food Science \& Technology, 46, 1031-1037.

50. Kandiah, M., Spiro, M. (1990). Extraction of ginger rhizome - kinetic-studies with supercritical carbon dioxide. International Journal of Food Science and Technology, 25, 328-338. 
51. Keita, S.M., Vincen,t C., Schmit, J.P., Belanger, A. (2000). Essential oil composition of Ocimum basilicum L., O. gratissimum L. and $O$. suave L. in the Republic of Guinea. Flavour Fragrance J., 15, 339-341.

52. Keita, S.M., Vincent, C., Schmit, J.P., Ramaswamy, S., Belanger, A. (2000). Effect of various essential oils on Callosobruchus maculatus (F.) (Coleoptera: Bruchidae). J. of Stored Product Research, 36 (4), 355-364.

53. Kelm, M.A., Nair, M.G., Strasburg, G.M., DeWitt, D.L. (2000). Antioxidant and cyclooxygenase inhibitory phenolic compounds from Ocimum sanctum Linn. Phytomedicine, 7 (1), 7-13.

54. King, J.W. (2002). Supercritical Fluid Extraction: Present Status and Prospects. Grasas y Aceites 53, 8-21.

55. Knežević, V. Superkritične tekućine (2008), www.pbf.unizg.hr./hr/content/download/.../Esuperkriticne+tekucine.pdf (01.08.2013)

56. Lang, Q., Wai, C.M. (2001). Supercritical fluid extraction in herbal and natural product studies - a practical review. Talanta, 53,771-782.

57. Lawrence, B.M. (1988). A World Perspective. Proceedings of the $10^{\text {th }}$ International Congree of Essential Oils, Fragrances and Flavours, Washington, DC, USA 1986, Elsevier Sciences Publisher B.V.: Amsterdam 161.

58. Lawrence, B.M., Hogg, J.W., Terhune, S.J. and Pichitakul, N. (1972). Essential oils and their constituents. IX. The oils of Ocimum sanctum and Ocimum basilicum from Thailand, Flavor Ind. Jan., 47-49.

59. Leal, P.F., Chaves, F.C.M., Ming, L.C., Petenate, A.J., Meireles, M.A.A. (2006). Global yields, chemical composition, antioxidant activities of clove basil (Ocimum gratissimum L.) extracts obtained by supercritical fluid extraction. J. of Food Process Eng., 29 (5), 547559.

60. Leal, P.F., Maia, N.B., Carmello, Q.A.C., Catharino, R.R., Eberlin, M.N., Meireles, M.A.A. (2008). Sweet basil (Ocimum basilicum) extracts obtained by supercritical fluid extraction (SFE): Global yields, chemical composition, antioxidant activity, and estimation of the cost of manufacturing. Food and Bioprocess Tech., 1 (4), 326-338.

61. Lee, J., Scagel, C.F. (2009). Chicoric acid found in basil (Ocimum basilicum L.) leaves. Food Chemistry., 115, 650-656.

62. Lepojević, Ž. (2000). Praktikum hemije i tehnologije farmaceutskih proizvoda. Tehnološki fakultet, Novi Sad. 
63. Liu Rui Hai. (2004). Potential synergy of phytochemicals in cancer prevention: Mechanism of action. The Journal of Nutrition, 3479S-3485S.

64. Luque de Castro, M.D., Jimenéz-Carmona, M.M. (2000). Where is supercritical fluid extraction going? Trends in analitycal chemistry, 19, 223-228.

65. Manach, C., Scalbert, A., Morand, C., Remesy, C., Jimenez, L. (2004). Polyphenols: food sources and bioavailability. American Journal of Clinical Nutrition, 79, 727-747.

66. Manaker, A., Kravets, M., Koel, M., Orav, A. (2004). Identification and characterization of supercritical fluid extracts from herbs. C. R. Chimie, 7, 629-633.

67. Marotti, M., Piccaglia, R. and Giovanelli, E. (1996). Differences in essential oil composition of basil (Ocimum basilicum L.) Italian cultivars related to morphological characteristics. J. Agr. Food Chem., 44: 3926-3929.

68. Marrone, C., Poletto, M., Reverchon, E., Stassi, A. (1998). Almond oil extraction by supercritical $\mathrm{CO}_{2}$ : experiments and modeling. Chemical Engineering Sciences, 53, 37113718.

69. Molgaard, P., Johnsen, S., Christensen, P., Cornet,t C. (2003). HPLC method validated for the simultaneous analysis of cichoric acid and alkamides in Echinacea purpurea plants and products. Journal of Agricultural and Food Chemistry, 51, 6922-6933.

70. Murga, R., Ruiz, R., Beltran, S., Cabezas, J.L. (2000). Extraction of natural complex phenols and tanins from grape seeds by using supercritical mixture of carbon dioxide and alcohol. J. Agric. Food Chem., 48, 3408-3412.

71. Naczk, M., Shahidi, F. (2006). Phenolics in cereals, fruits and vegetables: ccurrence, extraction and analysis. Journal of Pharmaceutical and Biomedical Analysis, 41, 15231542.

72. Nagababu, E., Rifkind, J. M., Sesikeram, B., \& Lakshmaiah N. (2010). Assessment of antioxidant activities of Eugenol by in vitro and in vivo methods. Methods in Molecular Biology, 610, 165-180.

73. Nebedum, J., Ajeigb,e K.O., Nwobodo, E., Uba, C., Adesanya, O., Fadera, O., Ofusori, D. (2009). Comparative study of the ethanolic extracts of four Nigerian plants against some pathogenic microorganisms. Res. J. of Medicinal Plant, 3 (1), 23-08.

74. Nguefack, J., Budde, B.B., Jakobsen, M. (2004). Five essential oils from aromatic plants of Cameroon: Their antibacterial activity and ability permeabilize the citoplazmic membrane of Listeria innocua examined by flow cytometry. Letters in Applied Microbiology, 39 (5), 395-400. 
75. Nikolovski, B. (2009). Kinetika i modelovanje ekstrakcije ulja iz bobica kleke (Juniperus communis) i semenki tikve (Cucurbita pepo) natkritičnim ugljendioksidom. Doktorska disertacija. Tehnološki fakultet, Univerzitet u Novom Sadu, Novi Sad.

76. Nikolovski, B. Sovilj, M., Đokić, M., Vidović, S. (2008). Kinetika i modelovanje ekstrakcije ulja iz semena lana (Linum usitatissimum L.) nadkritičnim ugljendioksidom. Hemijska industrija, 62, 283-292.

77. Norhuda, I., Jusoff, K. (2009). Supercritical carbon dioxide $\left(\mathrm{SC}-\mathrm{CO}_{2}\right)$ as a clean technology for palm kernel oil extraction. Journal of Biochemical Technology, 1, 75-78.

78. Nour, A. H., Elhussein, S.A., Osman, N.A., Nour, A.H. (2009). Repellent activities of the essential oils of four sudanese accesssions of basil (Ocimum basilicum L.) against Anopheles mosquito. J. of Applied Sciences, 9 (14), 2645-2648.

79. Nyam, K.L., Tan, C.P., Karim, R., Lai, O.M., Long, K., Che Man, Y.B. (2010). Extraction of tocopherol-enriched oils from Kalahari melon and roselle seeds by supercritical fluid extraction ( $\left.\mathrm{SFE}-\mathrm{CO}_{2}\right)$. Food Chemistry, 119, 1278-1283.

80. Oliveira, E.L.G., Silvestre, A.J.D., Silva, C.M. (2011). Review of kinetic models for supercritical fluid extraction, Chemical Engineering Resarch and Design, 38, 761-770.

81. Ozek, T., Beis, S.H., Demircakmak, B., Baser, K.H.C. (1995). Composition of the essential oil of Ocimum basilicum L. cultiveted in Turky. J. Essent. Oil Res., 7, 203-205.

82. Papamichail, I., Louli, V., Magoulas, K. (2000). Supercritical fluid extraction of celery seed oil. The Journal of Supercritical Fluids, 18, 213-226.

83. Paton, A. (1992). A synopsis of Ocimum L. (Labiate) in Africa. Kew Bul., 47, 403-435

84. Perrut, M., Clavier, J.Y., Poletto, M., Reverchon, E. (1997). Mathematical modelling of sunflower seed extraction by supercritical $\mathrm{CO}_{2}$. Industrial \& Engineering Chemistry Resarch, 36, 430-435.

85. Phippen, W.B. and Simon, J.E. (1998). Anthocyanins in basil, J. Agr. Food Chem., 46,1734-1738.

86. Pietta, P.G. (2000). Flavonoids as antioxidants. Journal of Natural Products, 63, 10351042.

87. Pino, J., Rosado, A., Goire, I., Roncal, E., Garcia, I. (1993). Analysis of the essential oil from cuban basil (Ocimum basilicum L.). Die Nahrung, 37, 501-504.

88. Pripdeevech, P., Chumpolsri, W., Suttiarporn, P., Wongpornchai, S. (2010). The chemical composition and antioxidant activities of basil from Thailand using retention indices and comprehensive tow-dimensional gas chromatography. J. of the Serb. Chem. Soc. 75 (11), 1503-1513. 
89. Radojković, M. (2012). Ekstrakti duda (Morus spp. Moraceae), sastav, delovanje i primena. Doktorska disertacija. Tehnološki fakultet, Univerzitet u Novom sadu, Novi Sad.

90. Rai, M.K., Qureshi, S., Pandey, A.K. (1999). In vitro susceptibility of opportunistic Fusarium spp. to essential oils. Mycoses, 42 (1-2), 97-101.

91. Ramirez, P., Fornari, T., Señoráns, F.J., Ibãnez, E., Reglero, G. (2005). Isolation of phenolic antioxidant compounds by SFE. J. Supercrit. Fluids, 35, 128-132.

92. Razavi, S.M.A., Mortazavi, S.A., Matia-Merino, L., Hosseini Parvar, S., Motamedzadegan, A., Khanipour, E. (2009). Optimisation study of gum extraction from Basil seed (Ocimum basilicum L.). Int. J. of Food Sci. and Tech., 44 (9), 1755-1762.

93. Reverchon, E. (1997). Supercritical fluid extraction and fractionation of essential oils and related products. The Journal of Supercritical Fluids, 10:1 - 37.

94. Reverchon, E., Daghero, J., Marrone, C., Mattea, M., Poletto, M. (1999). Supercritical fractional of fennel seed oil and essential oil: experiments and mathematical modeling. Industrial \& Engineering Chemistry Resarch, 38, 3069-3075.

95. Reverchon, E., De Marco, I. (2006). Supercritical fluid extraction and fractionation of natural matter. The Journal of Supercritical Fluids, 38: 146 - 166.

96. Reverchon, E., Donsi, G., Ossèo, L.S. (1993). Modeling of supercritical fluid extraction from hervaceous matrices. Industrial \& Engineering Chemistry Resarch, 32, 2721-2726.

97. Reverchon, E., Marrone, C. (2001). Modelling and simulation of the supercritical fluid extraction of vegetable oils. The Journal of Supercritical Fluids, 19, 161-175.

98. Reverchon, E., Sesti Ossèo, L. (1994). Modelling the supercritical extraction of basil oil. Third Int. Symp. Supercrit. Fluids, Vol 2., 189-196.

99. Reverchon, E., Sesti Ossèo, L., Gorgoglion, D. (1994). Supercritical $\mathrm{CO}_{2}$ extraction of basil oil: characterization of products and process modeling. The Journal of Supercritical Fluids, 7, (3), 185-190.

100. Rice-Evans, C.A., Packer, L. (2003) Flavonoids in Health and Disease. Boca Raton: CRC Press, 1-43.

101. Robards, K., Prenzler, P., Tucker, G., Swatsitang, P., Glover, W. (1999). Phenolic compounds and their role in oxidative processes in fruits, Food Chemistry, 66, 401-436.

102. Rodrigues, V.M., Tosa, P.T.V., Marques, M.O.M, Petenate, A.J., Meireles, M.A.A. (2003). Supercritical extraction of essential oil from Aniseed (Pimpinella anisum L.) using $\mathrm{CO}_{2}$ : solubility, kinetics and composition data. J. Agric. Food Chem., 51, 15181523. 
103. Ruberto, G., Spadaro, A., Piattelli, M., Piozzi, F., Passannanti, S. (1991). Volatile flavour components of Ocimum basilicum var. hispidum (Lam.) Chiov. Flavour Fragrance J., 6, 225-227.

104. Sahena, F., Zaidul, I.S.M., Jinap, S., Karim, A.A., Abbas, K.A., Norulaini, N.A.N., Omar, A.K.M. (2009). Application of supercritical $\mathrm{CO}_{2}$ in lipid extraction - A review. Journal of Food Engineering, 95, 240-253.

105. Sanchez, E., Garcia, S., Heredia, N. (2010). Extracts of edible and medicinal plants damage membranes of Vibrio cholerae. Applied and Environmental Microbiology, 76 (20), 6888-6894.

106. Sanda, K., Koba, K., Nambo, P., Gaset, A. (1998). Chemical investigation of Ocimum species growing in Togo. Flavour Fragrance J., 13, 226-232.

107. Shartar, S,. Altantsetseg, S. (2000). Essential oil composition of some plants cultivated in Mongolian climate. J. Essent. Oil Res., 12, 754-750.

108. Simon, J.E., Craker, L.E. and Chadwick, A. (1984). Herbs: an indexed bibliography, 1971-1980. The scientific literature on selected herbs, and aromatic and medicinal plants of the temperate zone. Archon Books, Hamden, Ct.

109. Simon, J.E., Quinn, J. And Murray, R.G. (1990). Basil: A source of essential oils. Advances in new crops. Timber Press, Portland, OR. 484-489.

110. Skala, D., Žižović, I., Gavrančić, S. (2002). Primena nadkritične ekstrakcije u prehrambenoj industriji. Hemijska industrija, 56(5), 179-190.

111. Sovová, H. and Stateva, R.P. (2011). Supercritical fluid extraction from vegetable materials. Rev. Chem. Eng., 27: 79-156.

112. Sovová, H. (1994). Rate of vegetable oil extraction with supercritical $\mathrm{CO}_{2}-$ modelling of extraction curves. Chemical Engineering Science, 49 (3), 409-414.

113. Sovová, H. (2005). Mathematical model for supercritical fluid extraction of natural products and extraction curve evaluation. The Journal of Supercritical Fluids, 33 (1), 3522.

114. Sovová, H., Kučera, J., Jež, J. (1994). Rate of vegetable oil extraction with supercritical $\mathrm{CO}_{2}$-II. Extraction of grape oil. Chemical Engineering Science, 49, 415-420.

115. Strack, D. (1997). Phenolic metabolism, U: Plant Biochemistry, Dey, P.M., Harborne, J.B. (Eds.), Academic Press, New York, 387-437.

116. Subra, P., Castellani, S., Jestin, P., Aoufi, A. (1998). Extraction of $\beta$-carotene with supercritical fluids: experimental and modeling. The Journal of Supercritical Fluids, 12, 261-269. 
117. Suppakul, P., Miltz, J., Sonneveld, K. and Bigger, S. (2003). Antimicrobial properties of basil and its possible application in food packaging. J.Agric. Food Chem., 51, 31973207.

118. Tagnolini, M., Barocelli, E., Ballabeni, V., Bruni, R., Bianchi, A., Chiavarini, M., Impicciatore, M. (2006). Comparative screening of plant essential oils: Phenylpropanoid moiety as basic core for antiplatelet activity. Life Sciences, 78 (13), 1419-1432.

119. Terens, W., Schwartz, K. (1995). Antioxidative constituents of Rosmarinus officinalis and Salvia officinalis IV. Determination of carnosic acid in different foodstuffs, Z Lebensm Unters Forsch, 201, 548-550.

120. Tucakov, J. (1990). Lečenje biljem, fitoterapija, Beograd.

121. Umeria, S.C., Anaso, H.U., Anyasoro, L.J.C. (1998). Insecticidal potentials of Ocimum basilicum leaf-extract. Bioresorce Tech., 64 (3), 237-239.

122. Vieira, R.F., Grayer, R.J., Paton, A.J. (2003). Chemical profiling of Ocimum amricanum using external flavonoids. Phytochemistry, 63, 555-567.

123. Vieira, R.F., Simon, J.E. (2000). Chemical characterization of basil (Ocimum spp.) found in the markets and use in traditional medicine in Brazil. Econ. Bot., 54, 207-216.

124. Vina, A., Murillo, E. Essential oil composition from twelve varieties of basil (Ocimum spp.) grow in Columbia. J. of Braz. Chem. Soc. (2003), 14 (5), 744-749.

125. Volpato, G.T., Damasceno, D.C., Calderon, I.M.P., Rudge, M.V.C. (2002). Review of Brazilian plants with proven hypoglycemic effect in the control of diabetes mellitus. Revista Brasileira de Plantes Medicinais, 4 (2), 35-45.

126. Wakao, N., Kaguei, S. (1982). Heat and mass transfer in packed beds. Gordon and Breach, New York, 156.

127. Wang, L., Weller, C.L. (2006). Recente advances in extraction of nutraceuticals from plants. Trends in Food Science \& Technology, 17, 300-312.

128. Wongsa, P., Chaiwarit, J., Zamaludien, A. (2012). In vitro screening of phenolic compounds, potential inhibition against $\alpha$-amylase and $\alpha$-glucosidase of culinary herbs in Thailand. Food Chemistry, 131 (3), 964-971.

129. Yanishlieva-Maslarova, N.V. (2001). Inhibiting oxidation. Antioxidants in Food, Pokorny, J., Yanishlieva, N., Gordon, M. (Eds.), CRC Press, Woodhead Publishing Limited, Cambridge, England, 23-70.

130. Yayi, E., Moudachirou, M., Chalchat, J.C. (2001). Chemotyping of three Ocimum species from Benin: O. basilicum, O. canum and O. gratissimum. J. Essent. Oil Res., $13,13-17$ 
131. Yun, Y.S., Nakajima, Y., Iseda, E., Kunugi, A. (2003). Determination of antioxidant activity of herbs by ESR. Journal of the Food Hygienic Society of Japan, 44 (1), 59-62.

132. Zeggwagh, N.A., Sulpice, T. Eddouks, M. (2007). Anti-hyperglycaemic and hypolipidemic effects of Ocimum basilicum aqueous extract in diabetic rats. Amer. J. of Pharm. and Toxic., 2 (3), 123-129.

133. Zeković, Z., Lepojević, Ž., Milić, S., Adamović, D., Mujić, I. (2009). Supercritical $\mathrm{CO}_{2}$ extraction of mentha (Mentha piperita L.) at different solvent densities. Journal of Serbian Chemical Society, 4 (4), 417-425.

134. Zeković, Z., Lepojević, Ž., Tolić, A. (2001). Modeling of the thyme-supercritical carbon dioxide extraction system; I. The influence of carbon dioxide flow rate and grinding degree of thyme. Separation Science and Technology, 36 (15), 3459-3472.

135. Zeković, Z., Lepojević, Ž., Tolić, A. (2003). Modeling of the thyme-supercritical carbon dioxide extraction system; II. The influence of extraction time and carbon dioxide pressure. Separation Science and Technology, 38 (3), 541-552.

136. Zollo, A., P.H., Biyiti, L., Tchoumbougnang, F., Menut, C., Lamaty, G., Bouchet, P.H. (1998). Aromatic plants of tropical central Africa. Part XXXII. Chemical composition and antifungal activity of thirteen essential oils from aromatic plants of Cameroon. Flavour Fragrance J., 13, 107-114. 


\section{PRILOG}

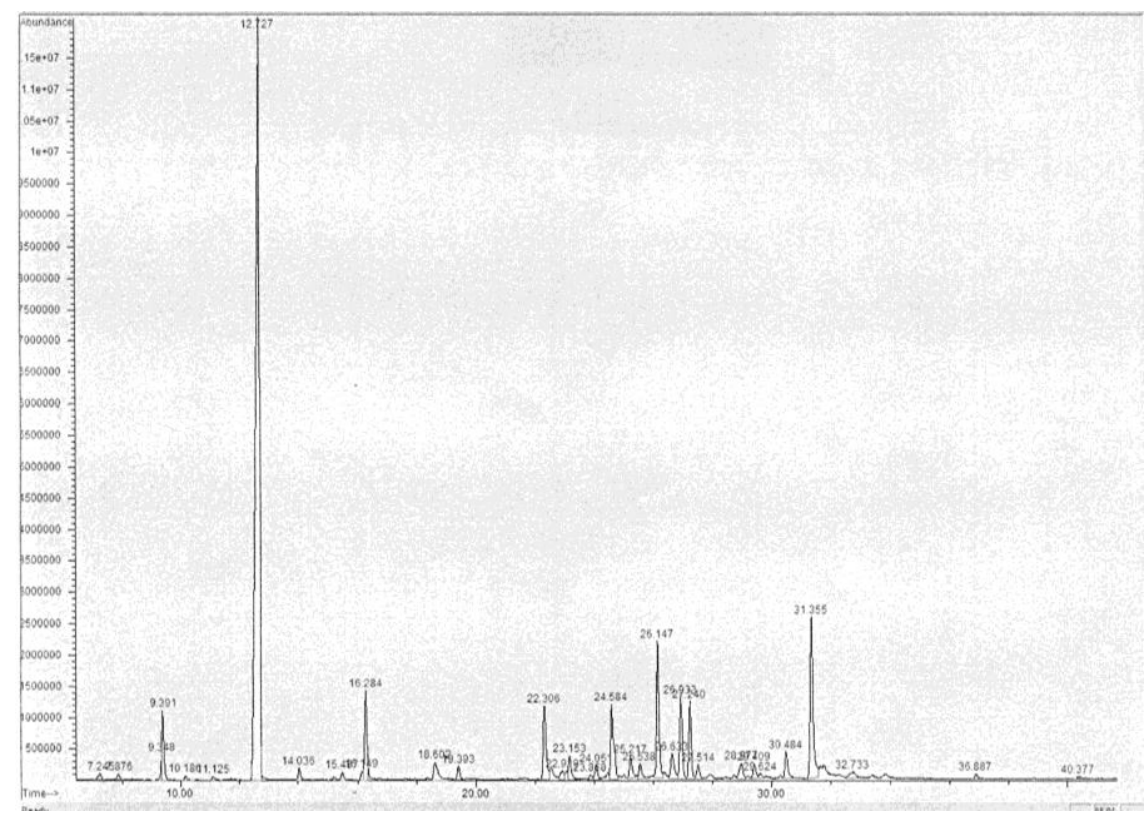

Slika P1. GC hromatogram etarskog ulja bosiljka

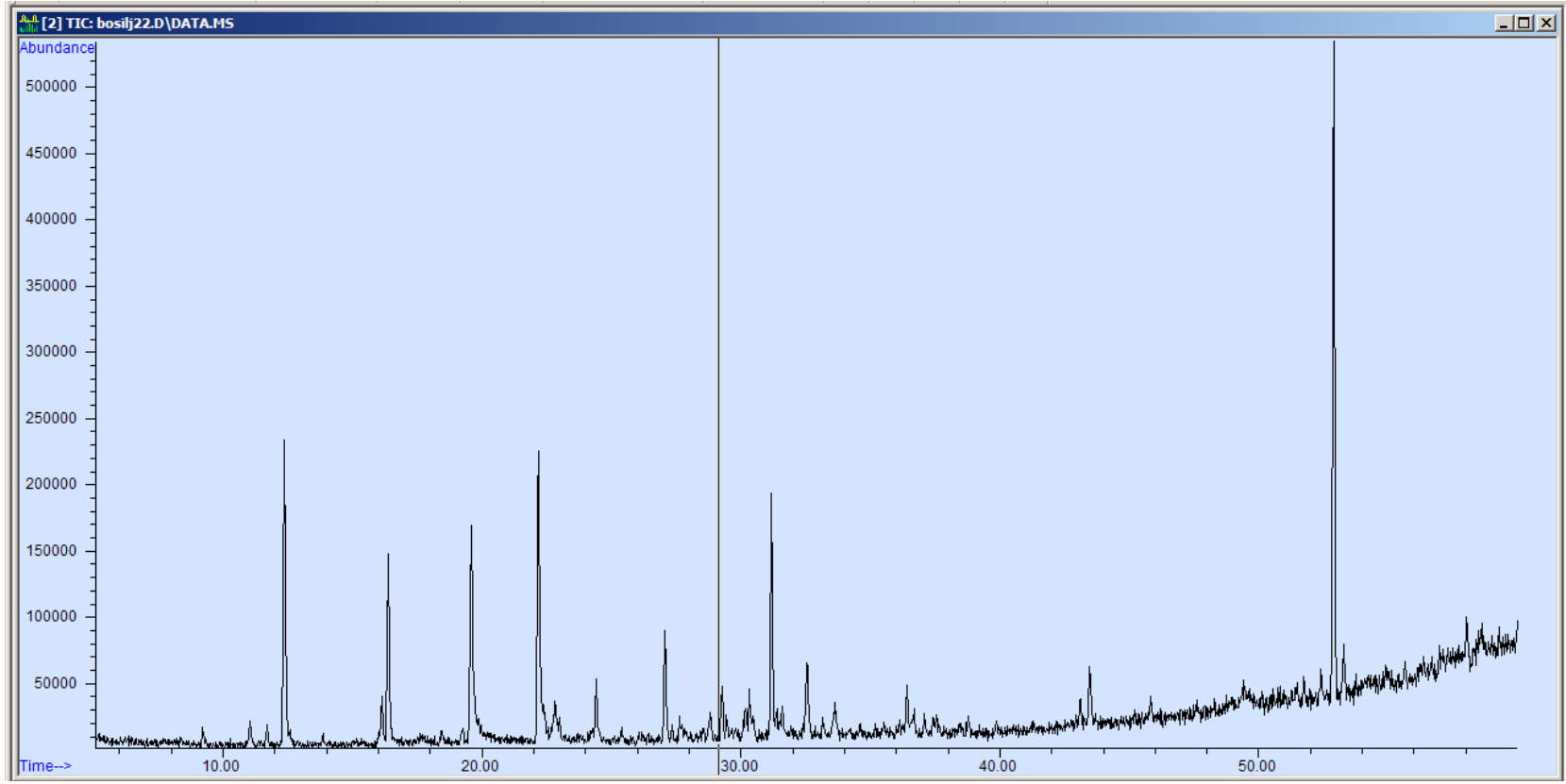

Slika P2. GC hromatogram ekstrakta bosiljka dobijenog Soxhlet ekstrakcijom 


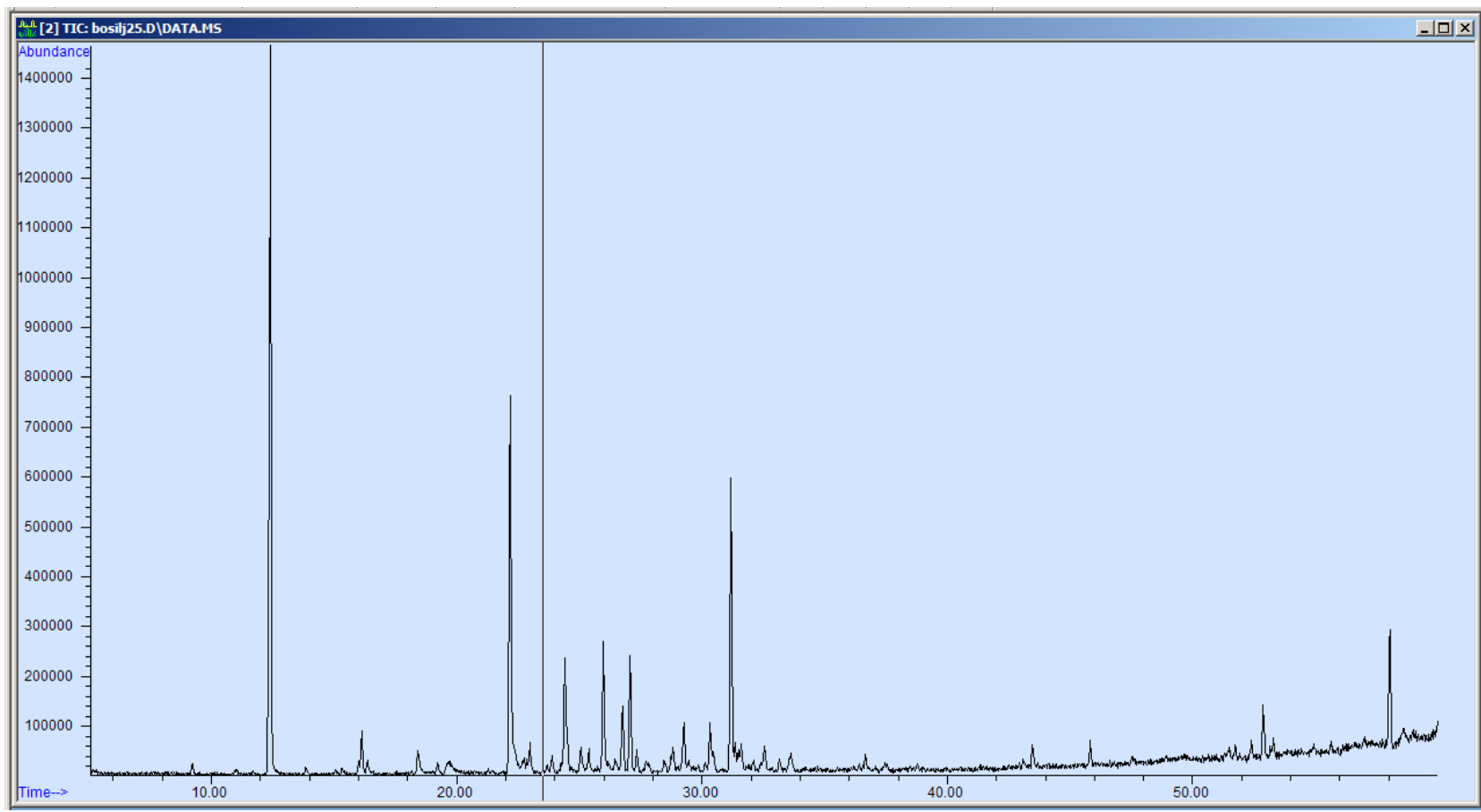

Slika P3. GC hromatogram totalnog $\mathrm{CO}_{2}$ ekstrakta bosiljka na 100 bara i $40^{\circ} \mathrm{C}$

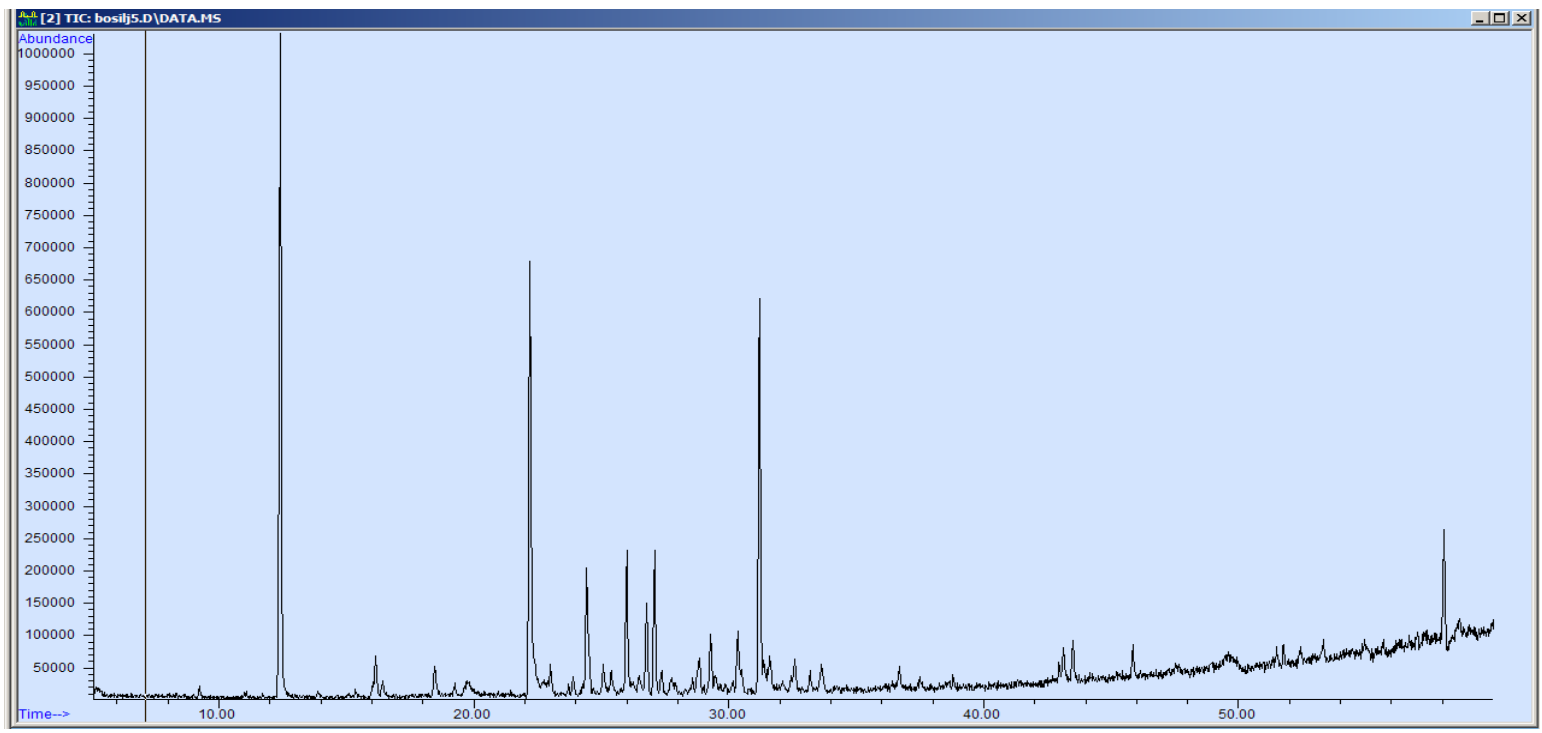

Slika P4. GC hromatogram totalnog $\mathrm{CO}_{2}$ ekstrakta bosiljka na 100 bara i $50^{\circ} \mathrm{C}$ 


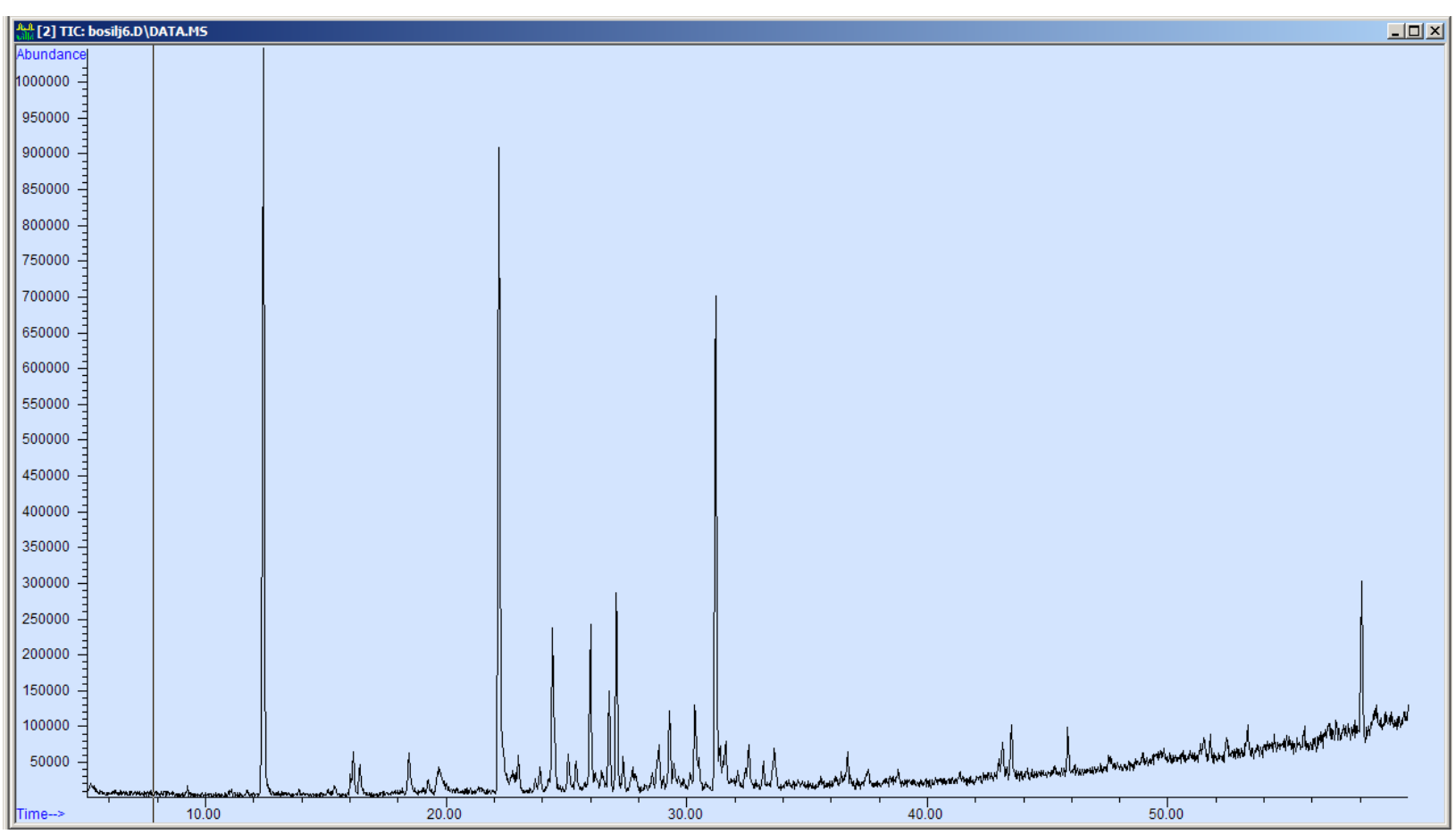

Slika P5. GC hromatogram totalnog $\mathrm{CO}_{2}$ ekstrakta bosiljka na 100 bara i $60^{\circ} \mathrm{C}$

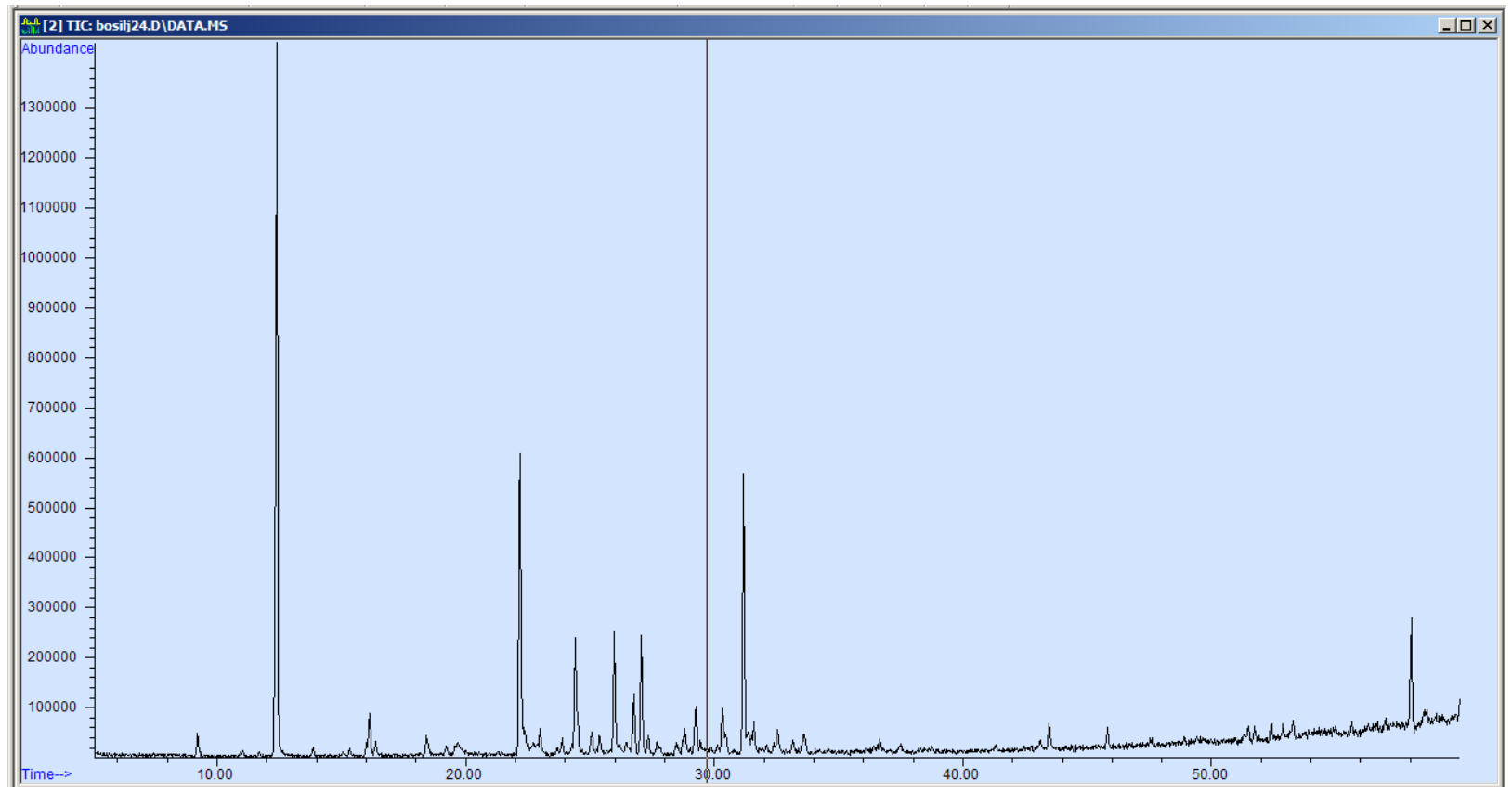

Slika P6. GC hromatogram totalnog $\mathrm{CO}_{2}$ ekstrakta bosiljka na 150 bara i $40^{\circ} \mathrm{C}$ 


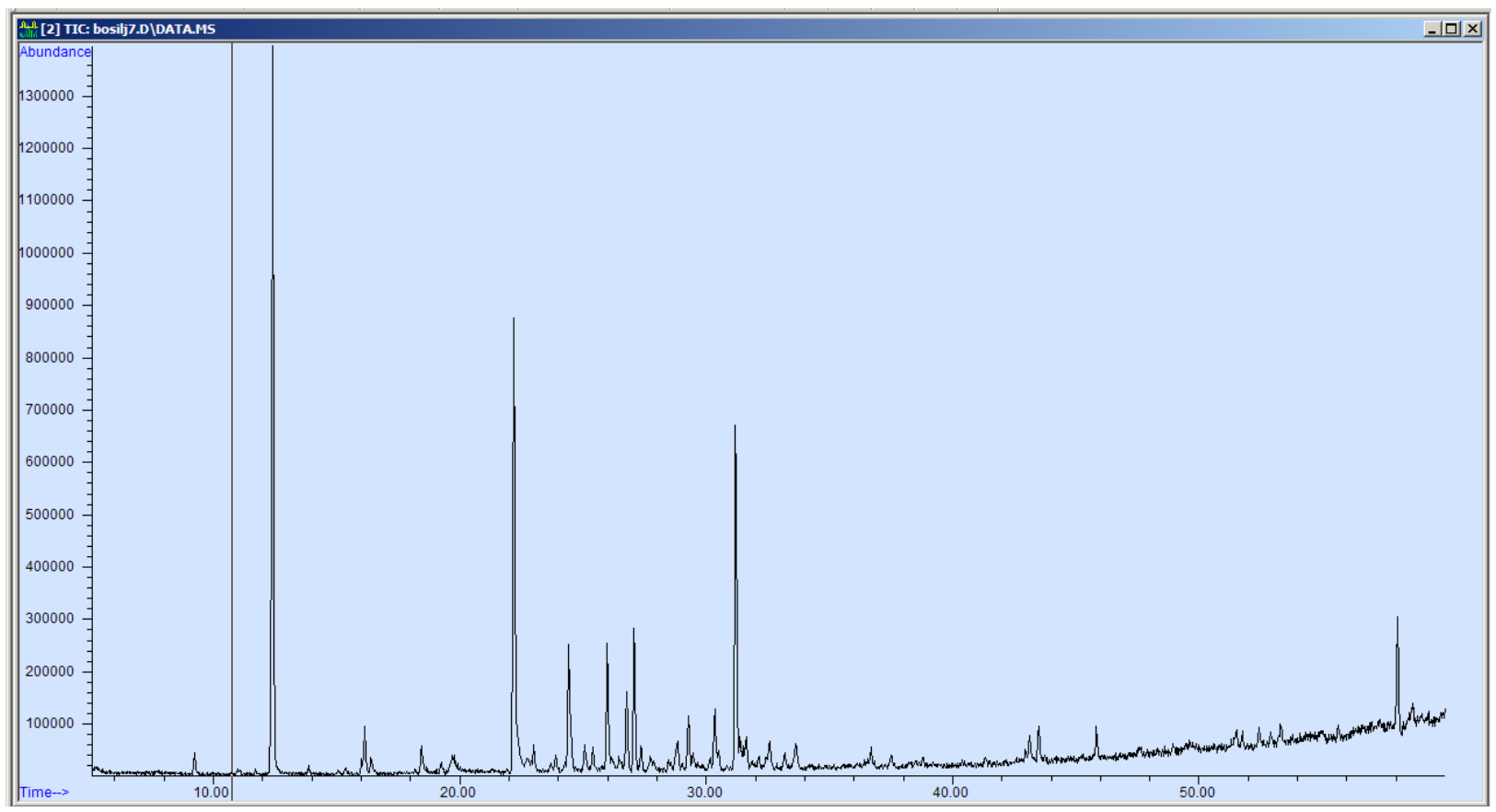

Slika P7. GC hromatogram totalnog $\mathrm{CO}_{2}$ ekstrakta bosiljka na 150 bara i $50^{\circ} \mathrm{C}$

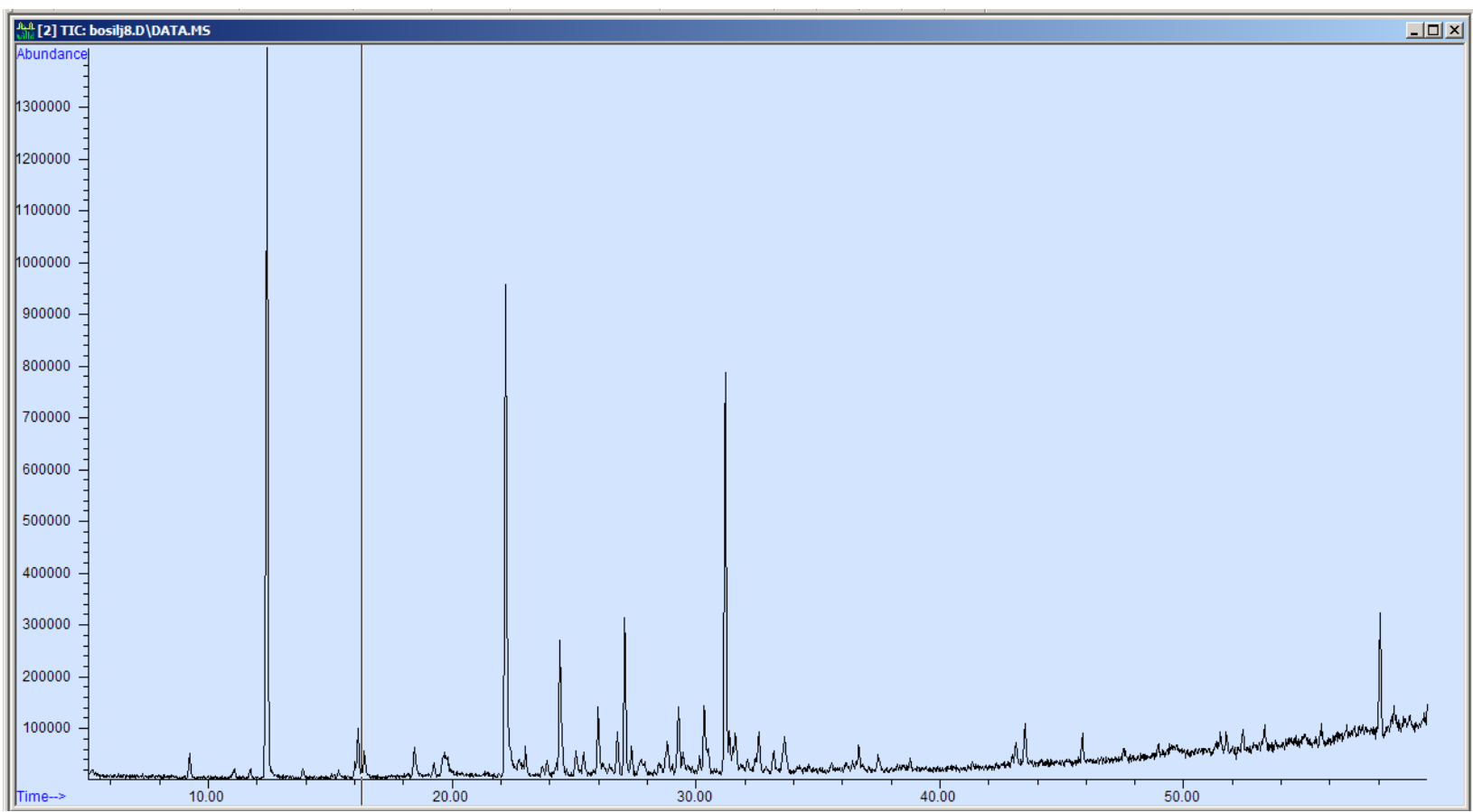

Slika P8. GC hromatogram totalnog $\mathrm{CO}_{2}$ ekstrakta bosiljka na 150 bara i $60^{\circ} \mathrm{C}$ 


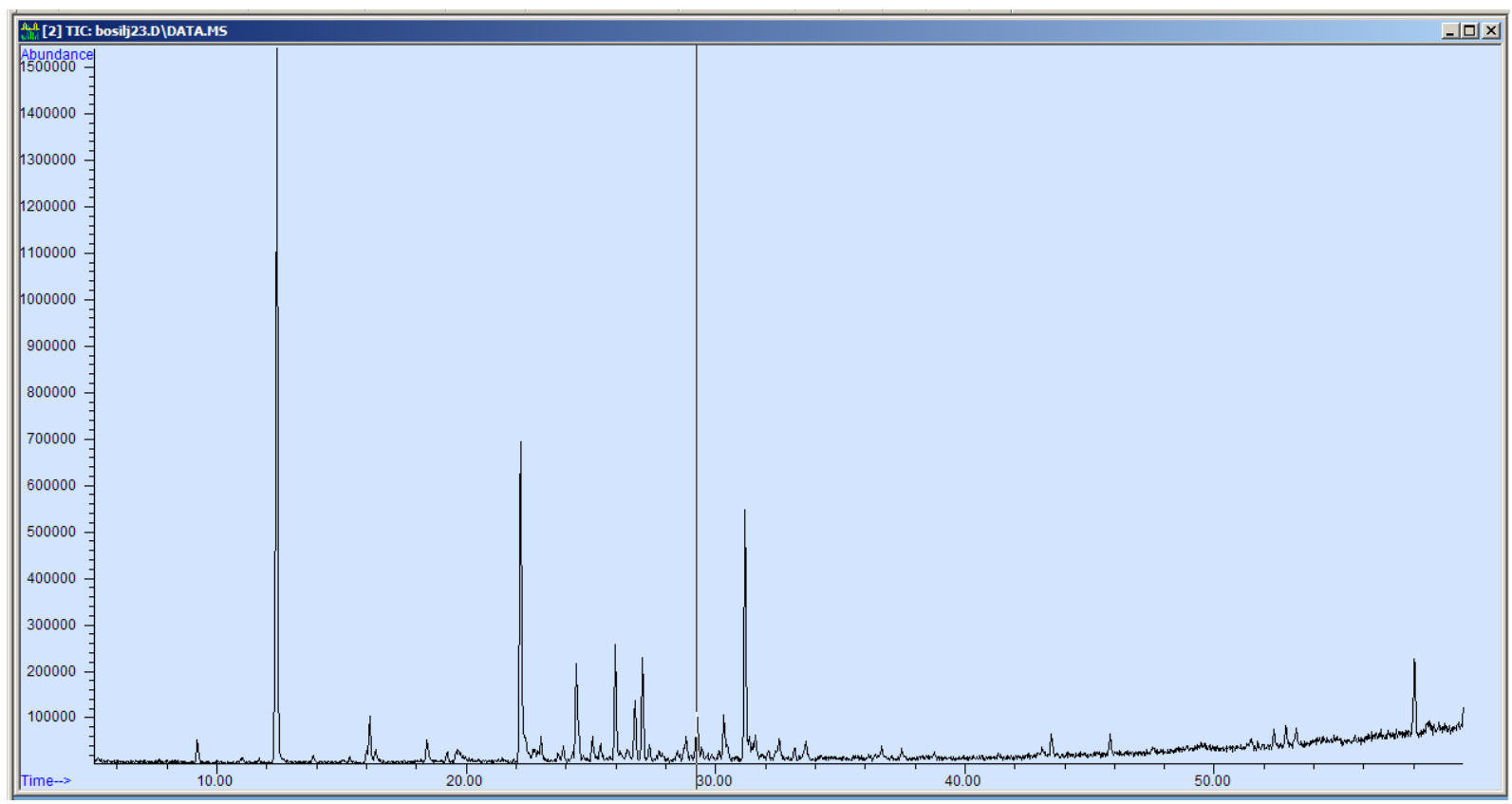

Slika P9. GC hromatogram totalnog $\mathrm{CO}_{2}$ ekstrakta bosiljka na 200 bara i $40^{\circ} \mathrm{C}$

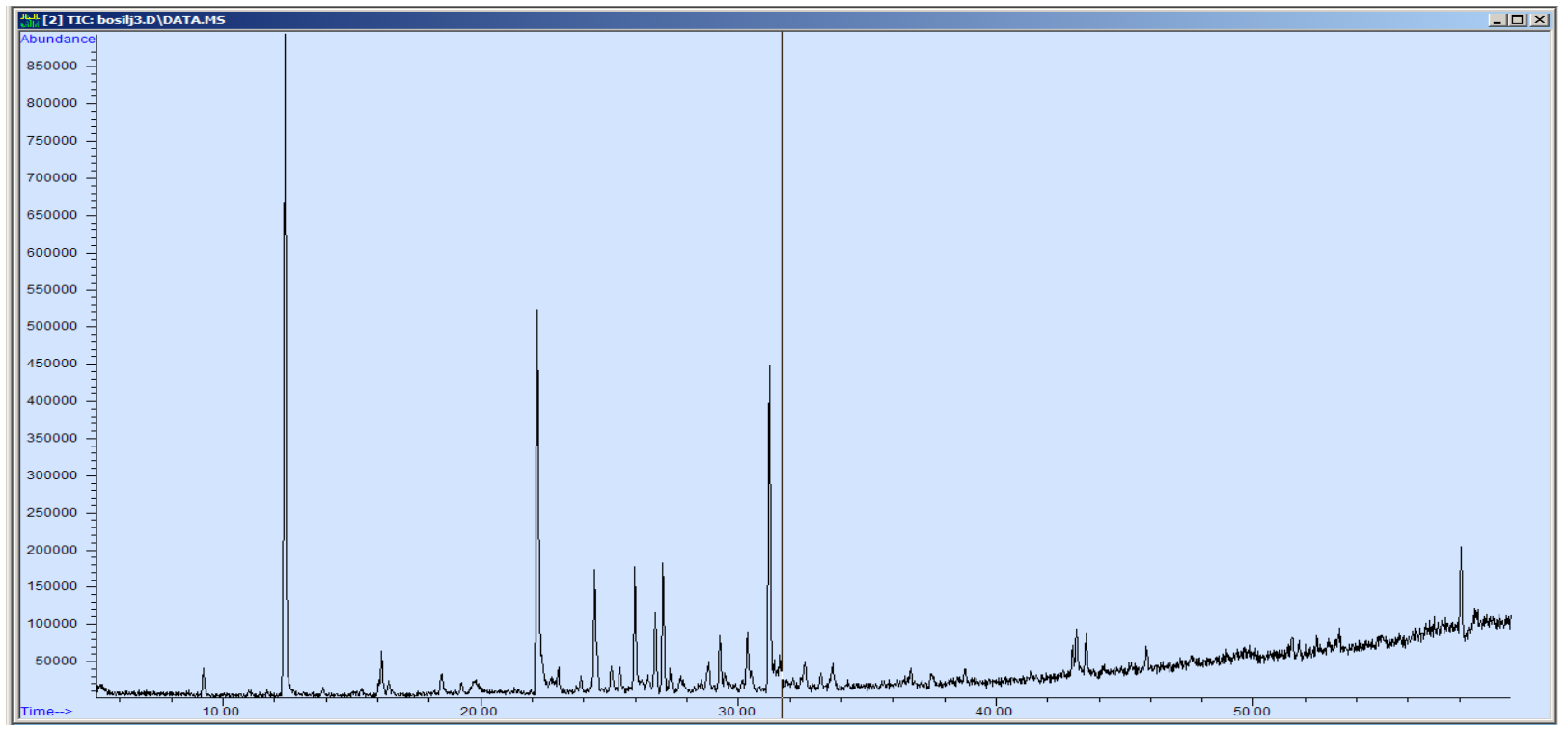

Slika P10. GC hromatogram totalnog $\mathrm{CO}_{2}$ ekstrakta bosiljka na 200 bara i $50^{\circ} \mathrm{C}$ 


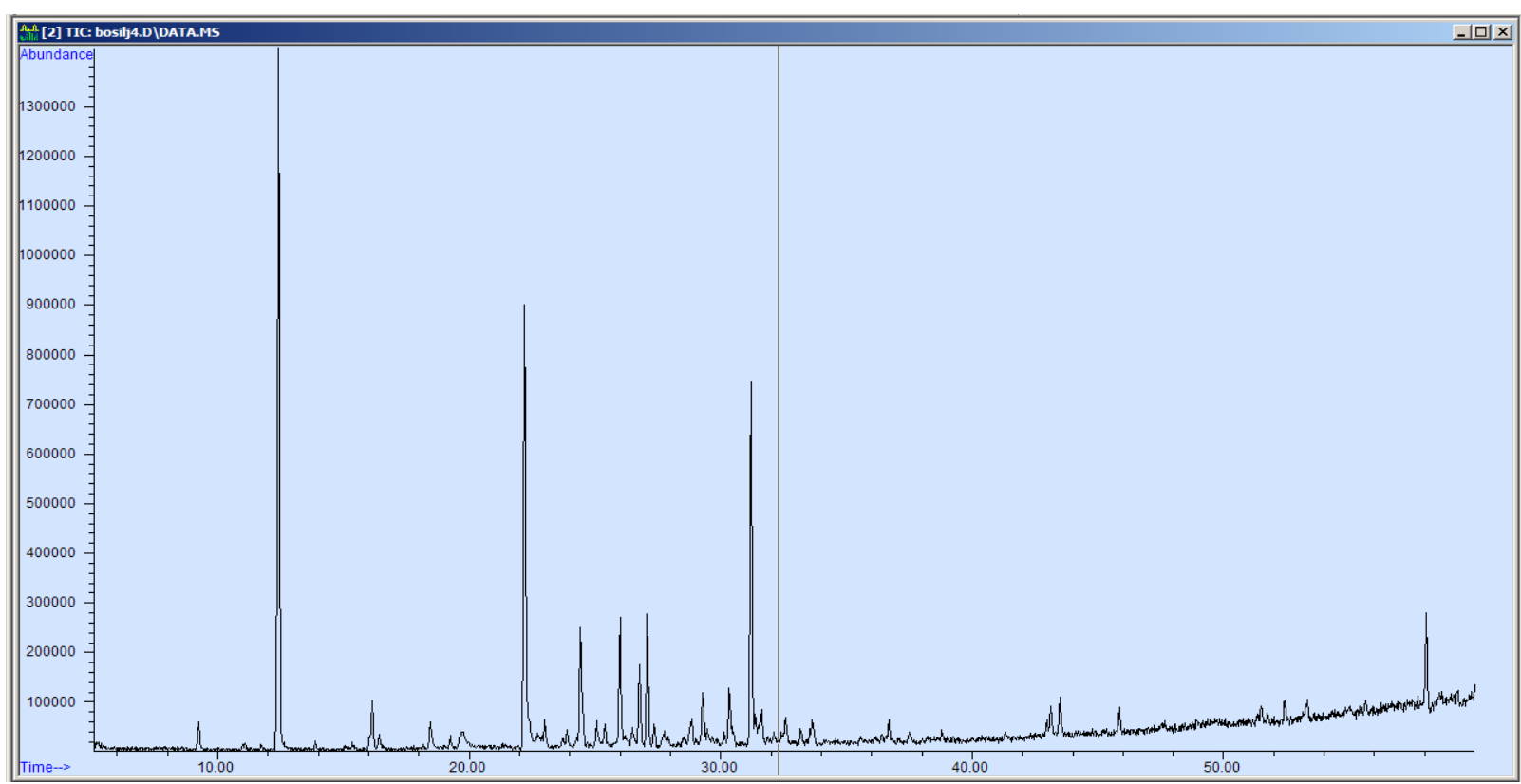

Slika P11. GC hromatogram totalnog $\mathrm{CO}_{2}$ ekstrakta bosiljka na 200 bara i $60^{\circ} \mathrm{C}$

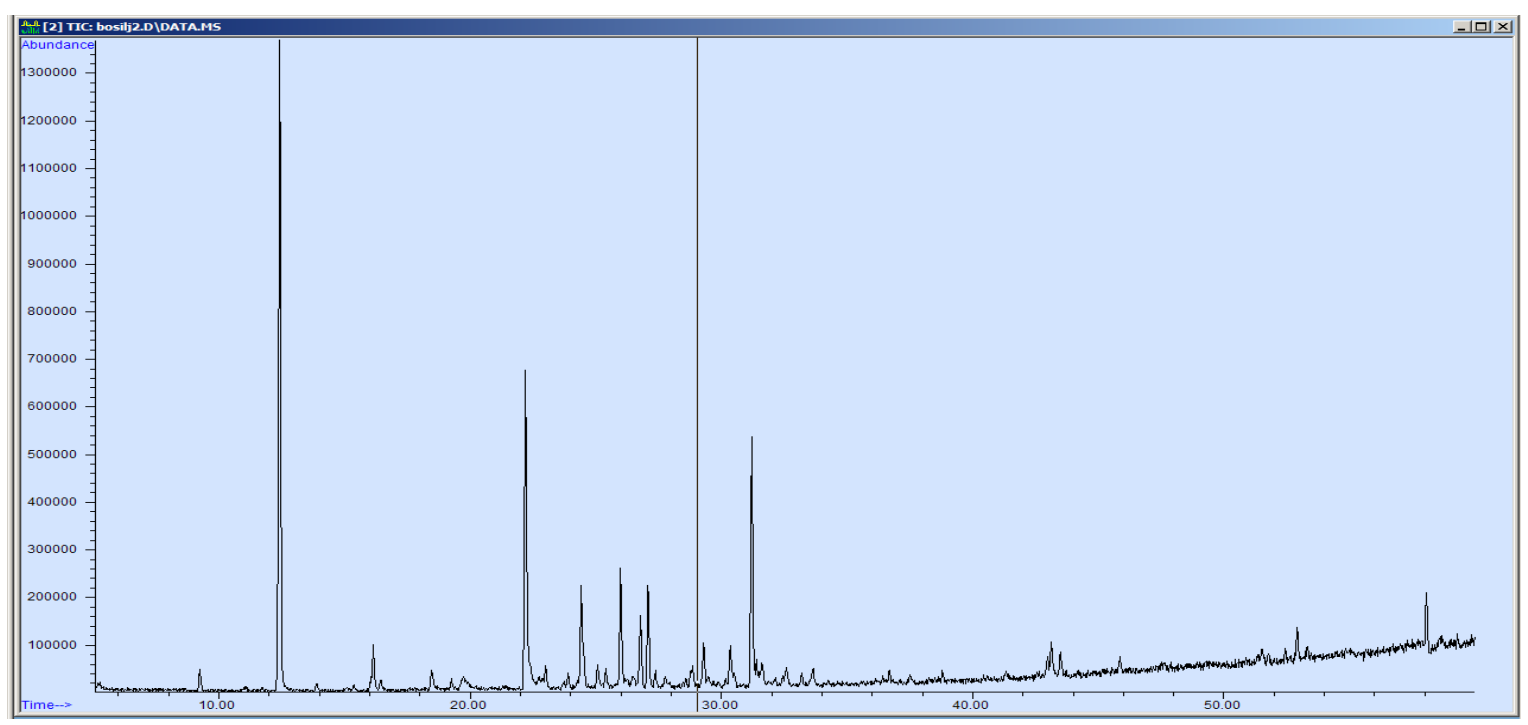

Slika P12. GC hromatogram totalnog $\mathrm{CO}_{2}$ ekstrakta bosiljka na 300 bara i $40^{\circ} \mathrm{C}$ 


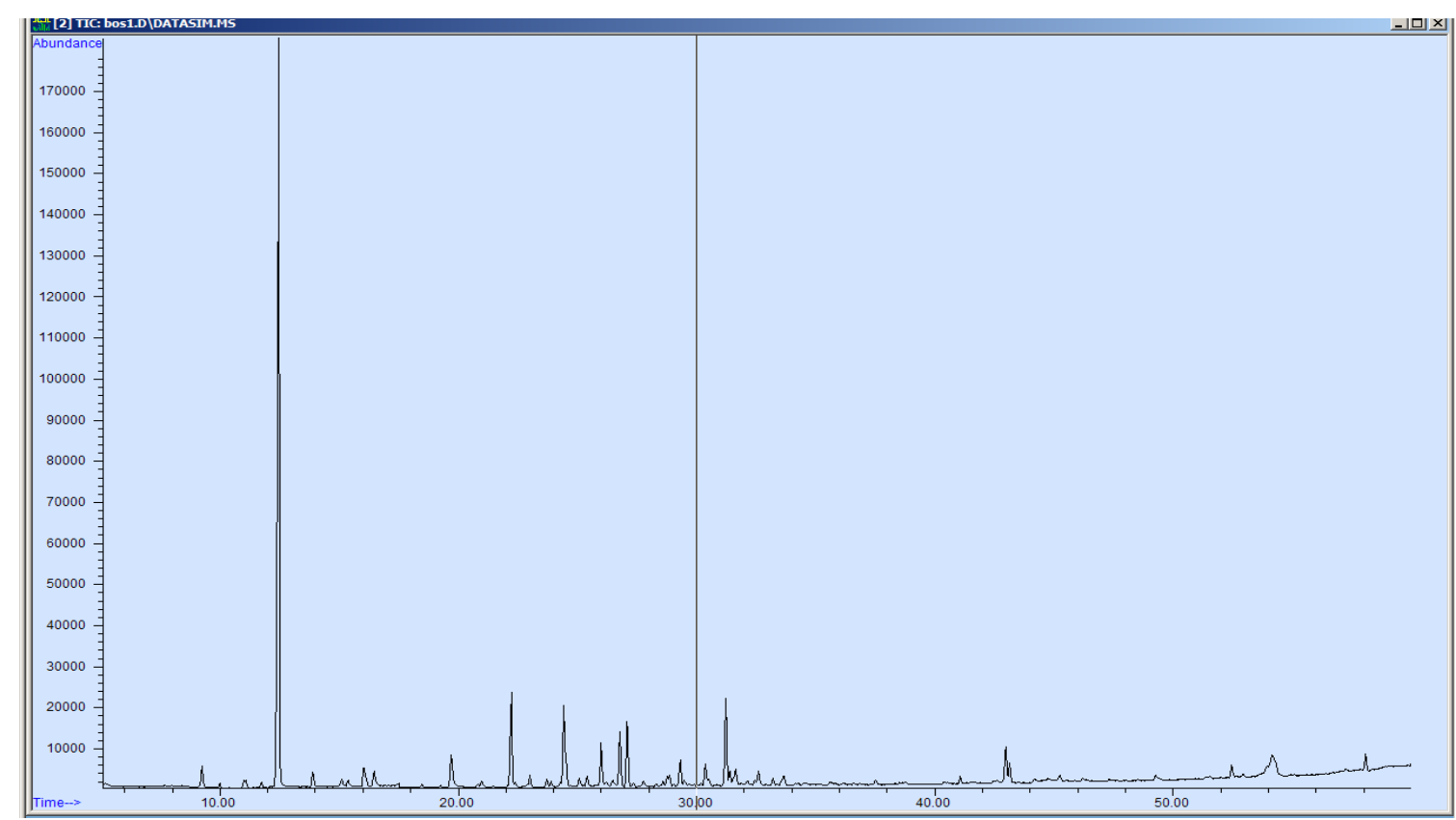

Slika P13. GC hromatogram totalnog $\mathrm{CO}_{2}$ ekstrakta bosiljka na 300 bara i $50^{\circ} \mathrm{C}$

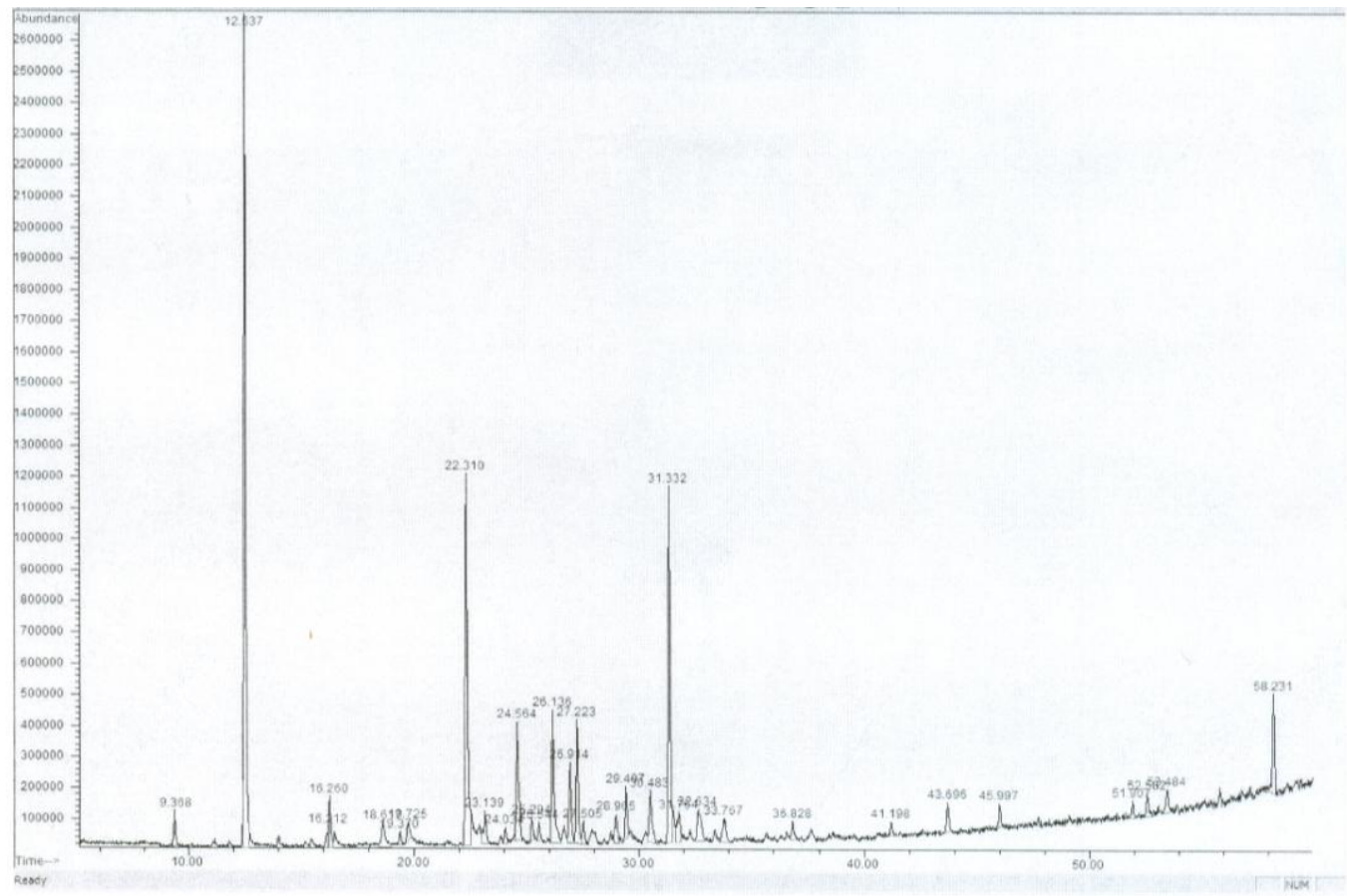

Slika P14. GC hromatogram totalnog $\mathrm{CO}_{2}$ ekstrakta bosiljka na 300 bara i $60^{\circ} \mathrm{C}$ 


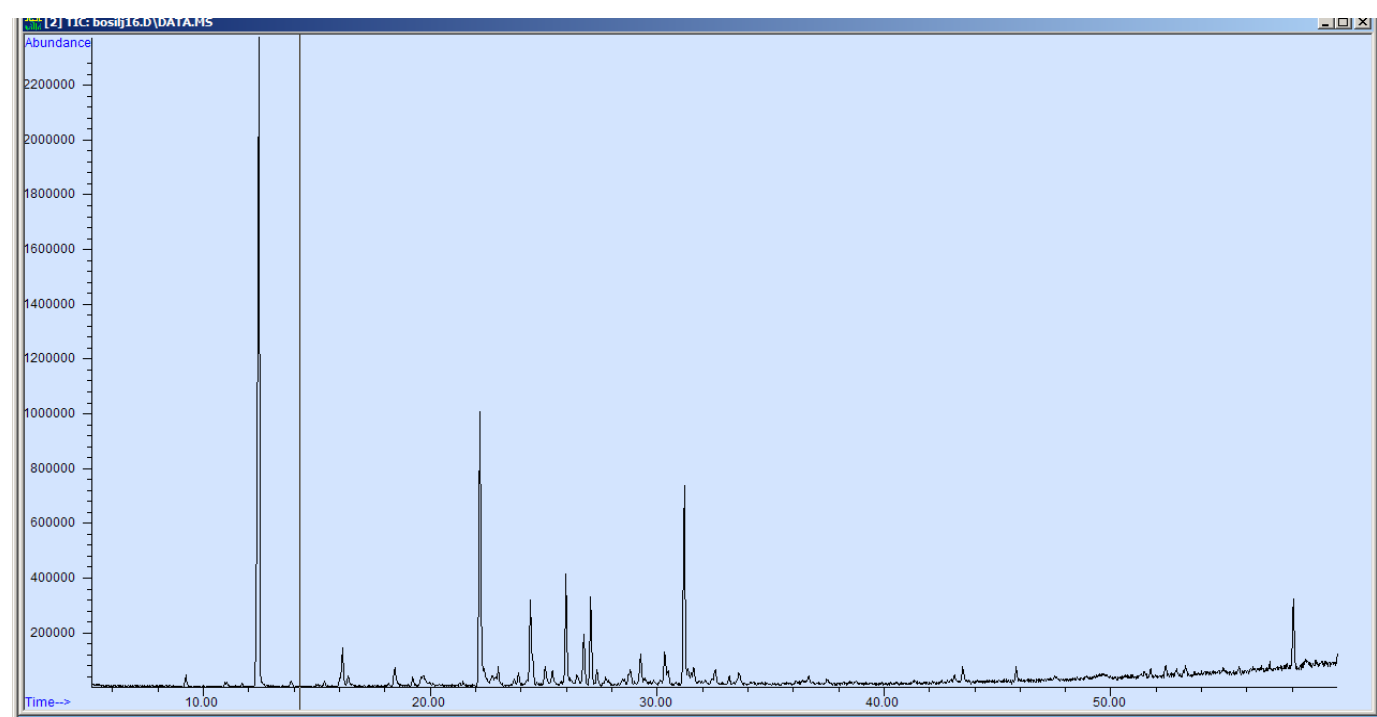

Slika P15. GC hromatogram $\mathrm{CO}_{2}$ ekstrakta bosiljka frakcionisanog na 100 bara i $40^{\circ} \mathrm{C}$

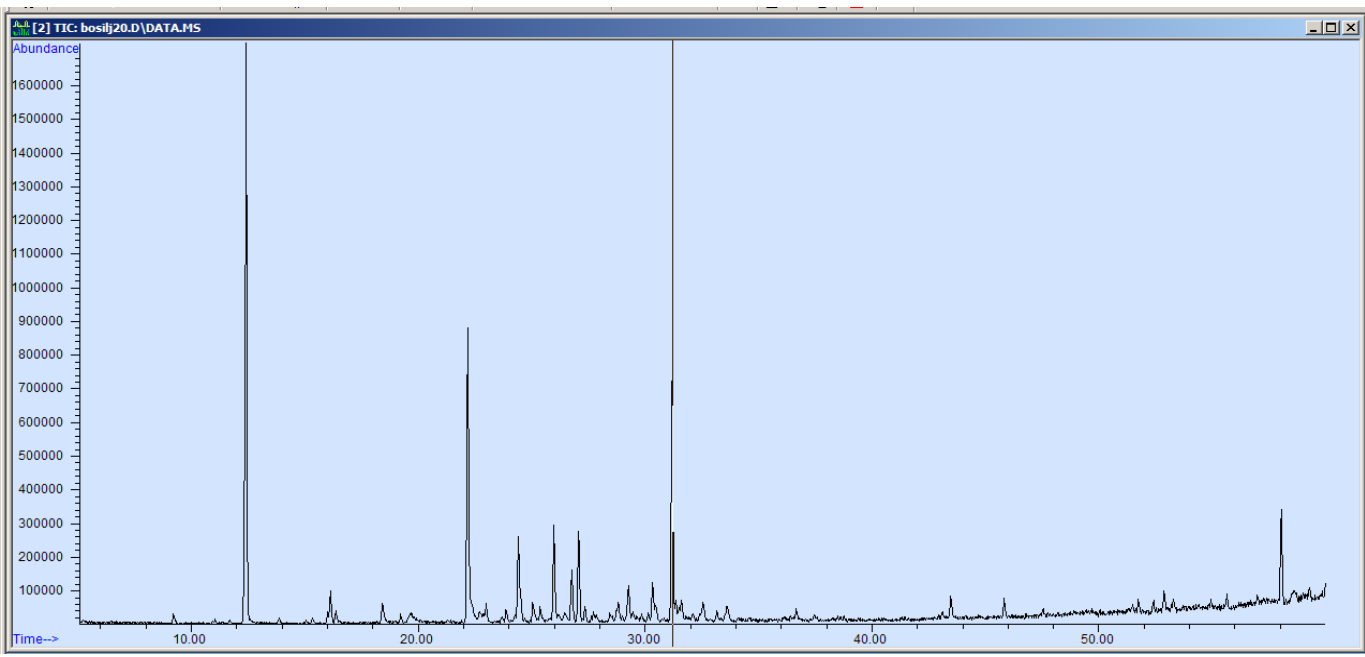

Slika P16. GC hromatogram $\mathrm{CO}_{2}$ ekstrakta bosiljka frakcionisanog na 100 bara i $50^{\circ} \mathrm{C}$

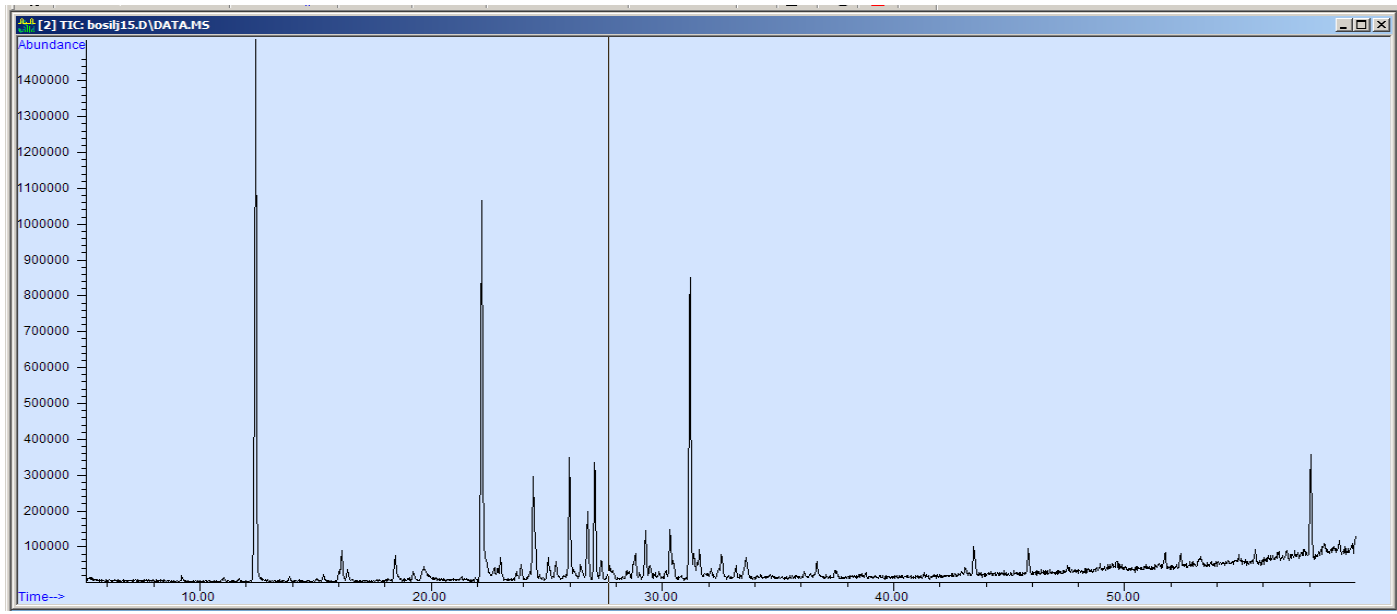

Slika P17. GC hromatogram $\mathrm{CO}_{2}$ ekstrakta bosiljka frakcionisanog na 100 bara i $60^{\circ} \mathrm{C}$ 


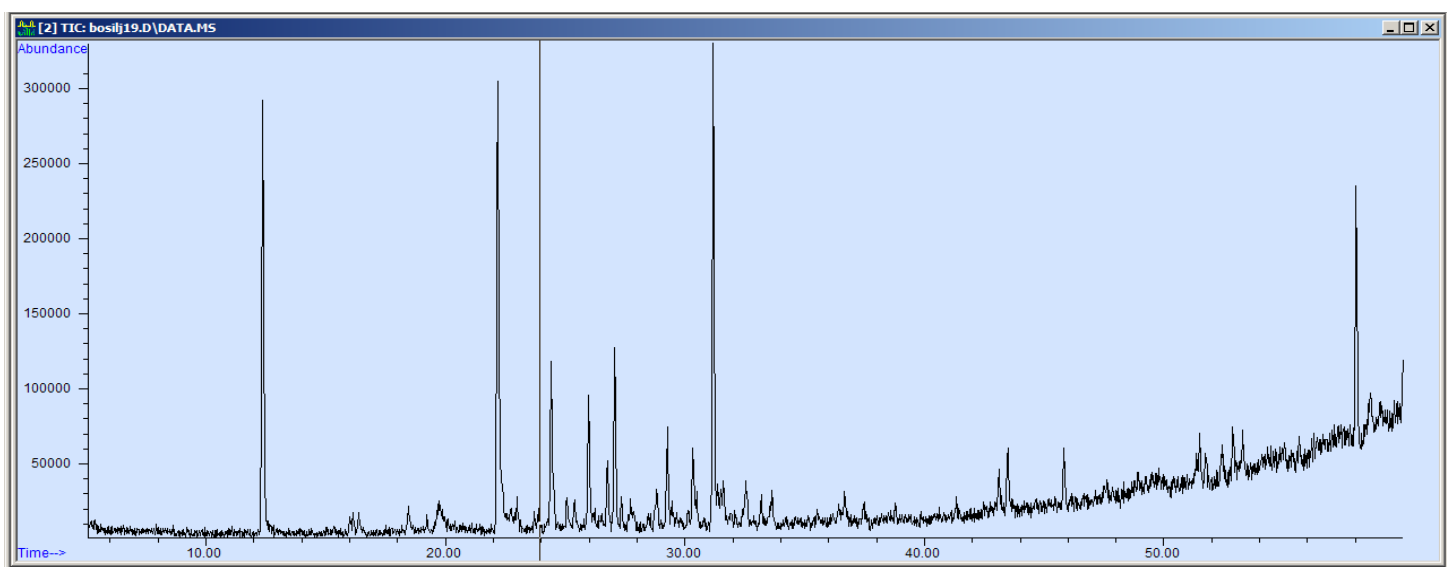

Slika P18. GC hromatogram $\mathrm{CO}_{2}$ ekstrakta bosiljka frakcionisanog na 150 bara i $40^{\circ} \mathrm{C}$

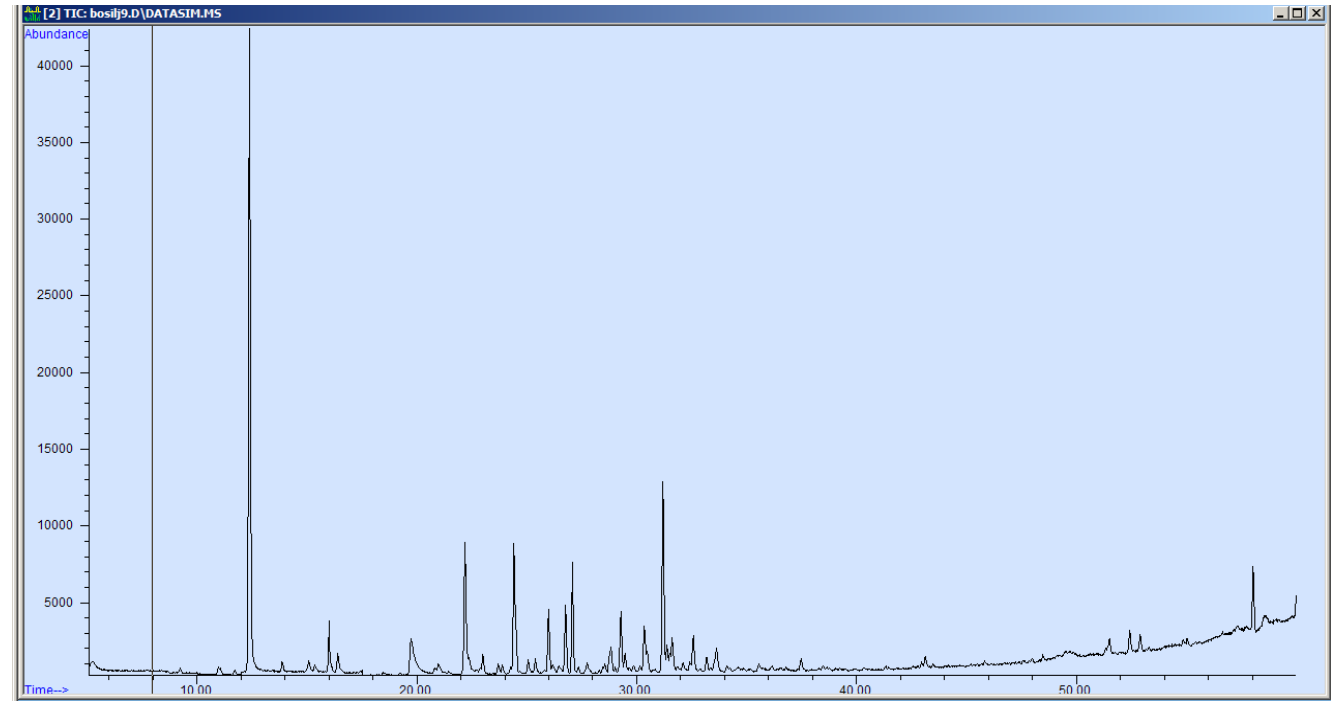

Slika P19. GC hromatogram $\mathrm{CO}_{2}$ ekstrakta bosiljka frakcionisanog na 150 bara i $50^{\circ} \mathrm{C}$

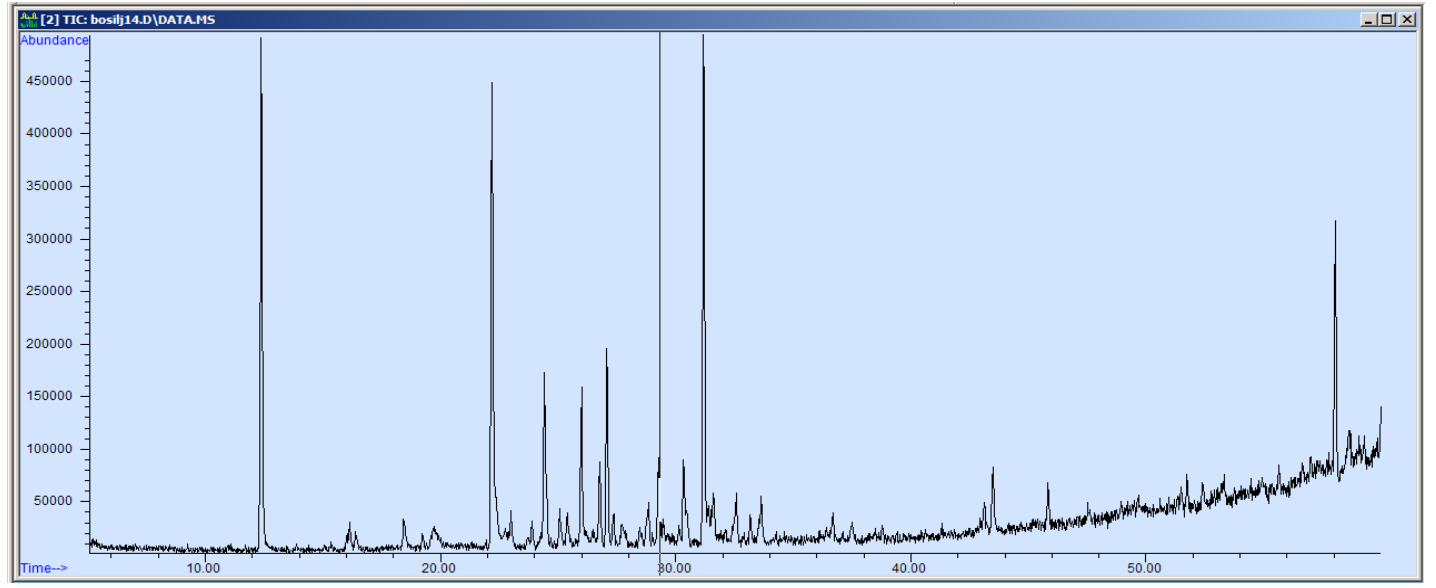

Slika P20. GC hromatogram $\mathrm{CO}_{2}$ ekstrakta bosiljka frakcionisanog na 150 bara i $60^{\circ} \mathrm{C}$ 


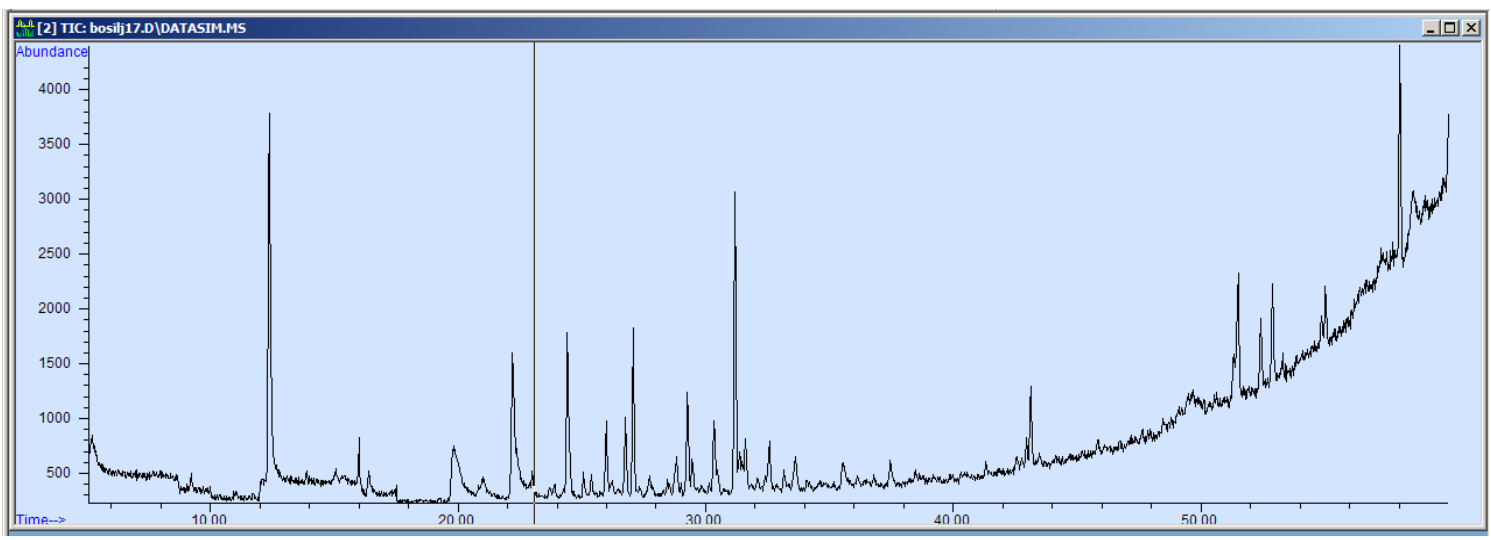

Slika P21. GC hromatogram $\mathrm{CO}_{2}$ ekstrakta bosiljka frakcionisanog na 200 bara i $40^{\circ} \mathrm{C}$

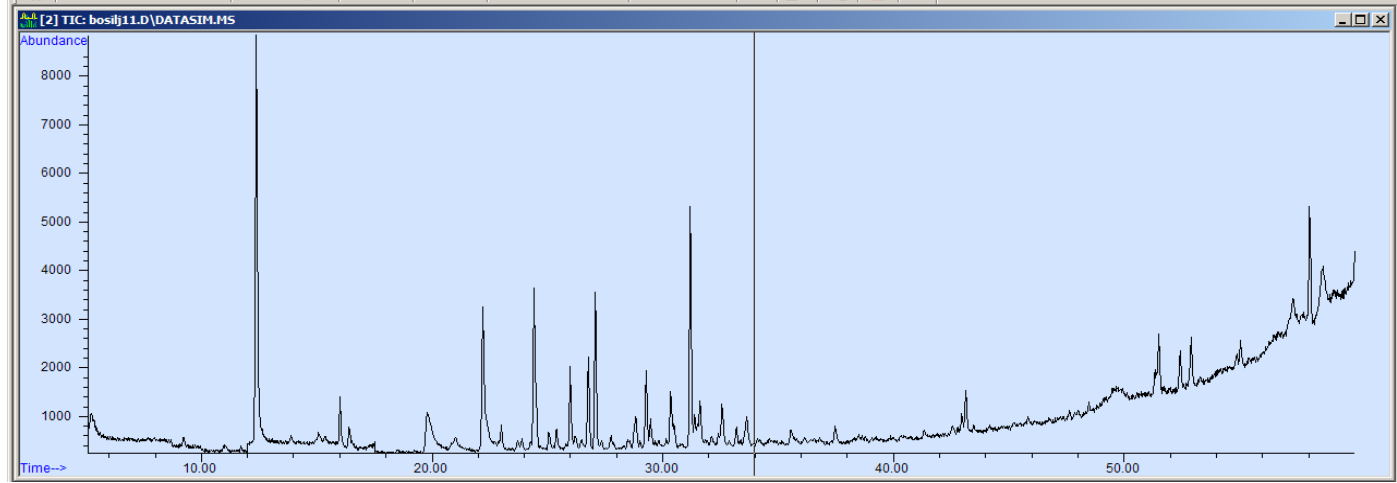

Slika P22. GC hromatogram $\mathrm{CO}_{2}$ ekstrakta bosiljka frakcionisanog na 200 bara i $50^{\circ} \mathrm{C}$

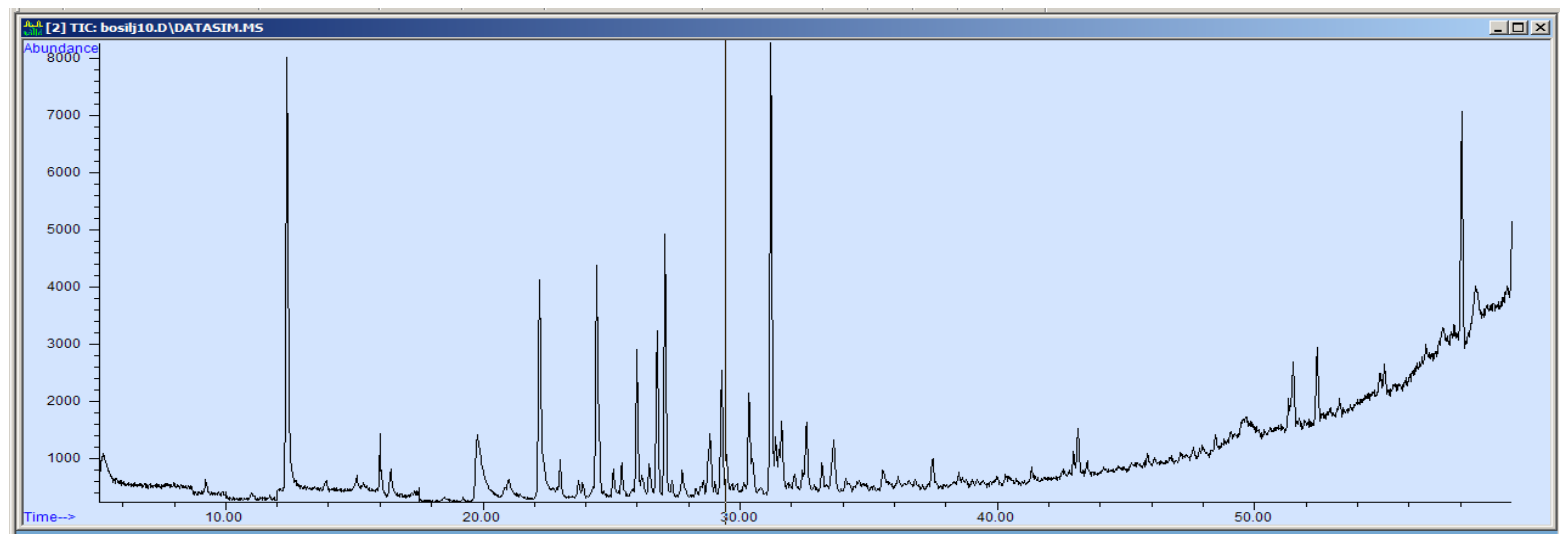

Slika P23. GC hromatogram $\mathrm{CO}_{2}$ ekstrakta bosiljka frakcionisanog na 200 bara i $60^{\circ} \mathrm{C}$ 


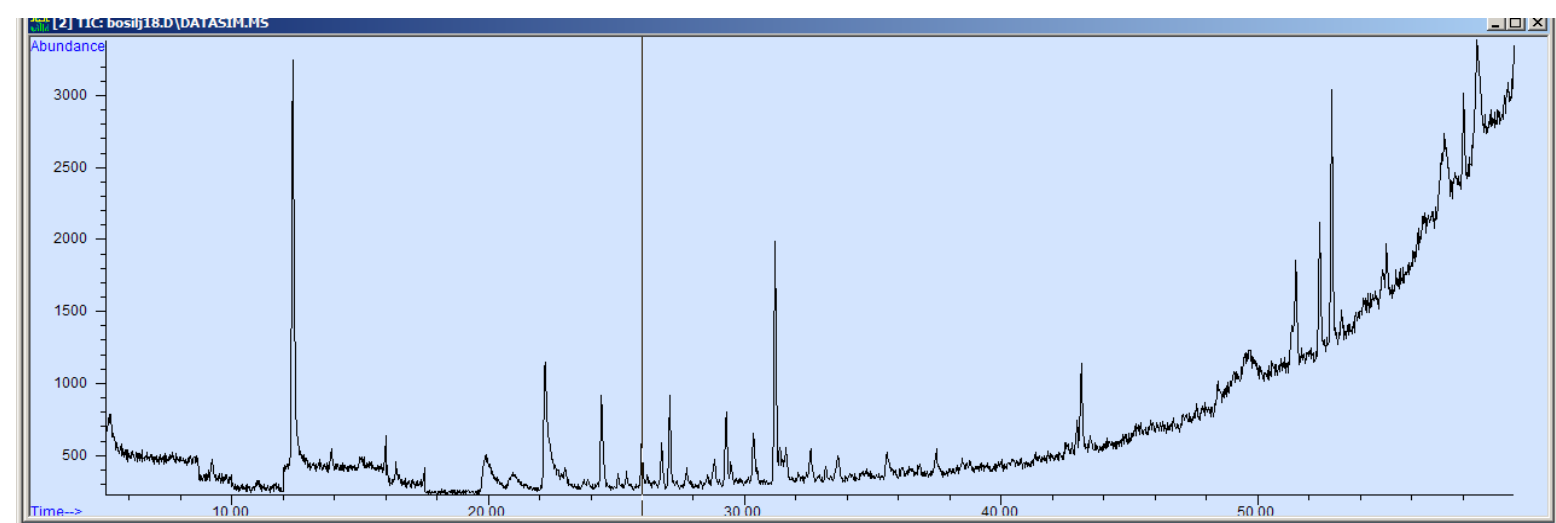

Slika P24. GC hromatogram $\mathrm{CO}_{2}$ ekstrakta bosiljka frakcionisanog na 300 bara i $40^{\circ} \mathrm{C}$

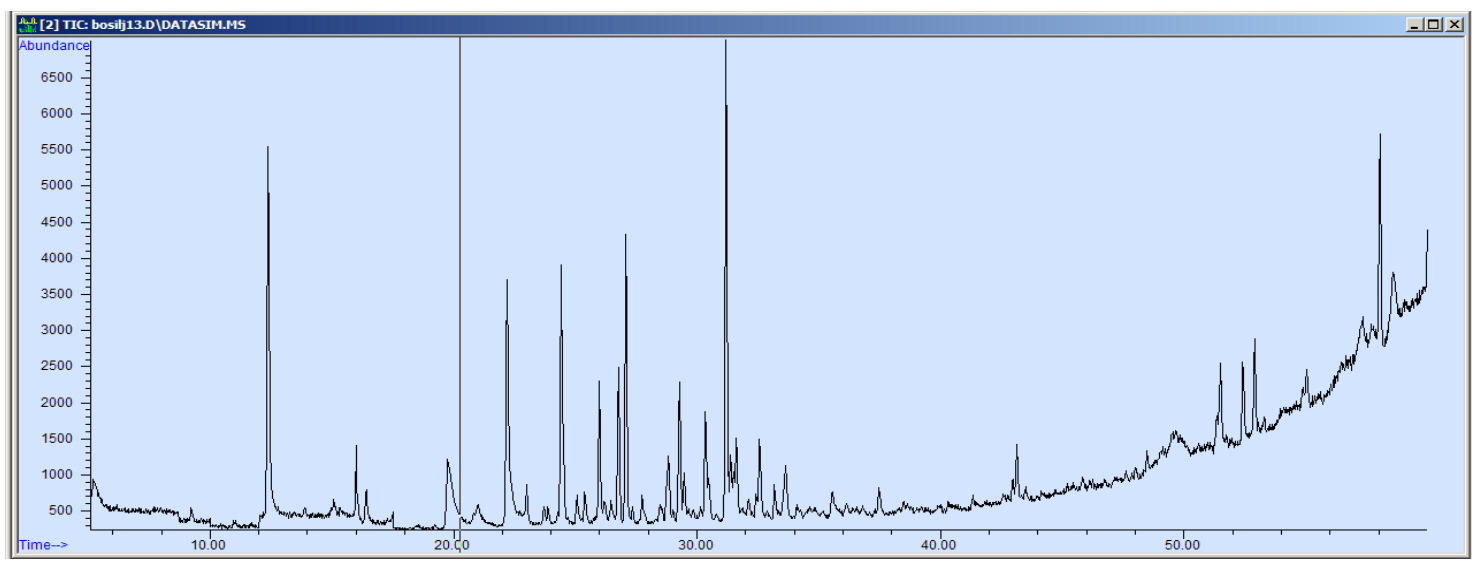

Slika P25. GC hromatogram $\mathrm{CO}_{2}$ ekstrakta bosiljka frakcionisanog na 300 bara i $50^{\circ} \mathrm{C}$

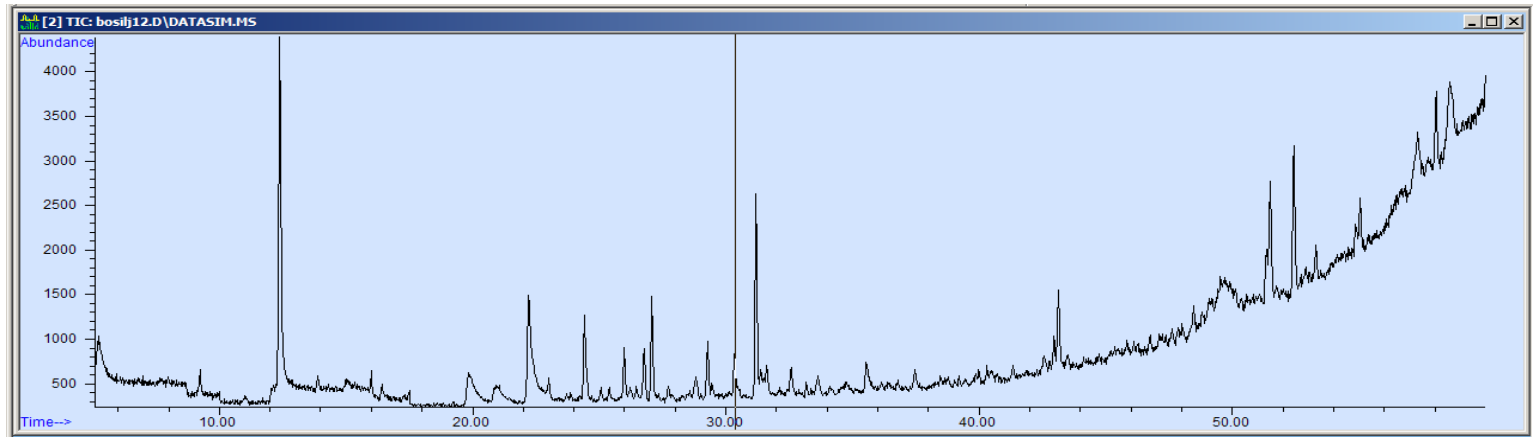

Slika P26. GC hromatogram $\mathrm{CO}_{2}$ ekstrakta bosiljka frakcionisanog na 300 bara i $50^{\circ} \mathrm{C}$ 
Tabela 15. Relativni udeo komponenata totalnog ekstrakata dobijenih superkritičnom ekstrakcijom

\begin{tabular}{|c|c|c|c|c|c|c|c|c|c|c|c|c|}
\hline \multirow{3}{*}{ Komponente } & \multicolumn{12}{|c|}{ Relativni udeo (\%) } \\
\hline & \multicolumn{12}{|c|}{ Pritisak (bar)/temperatura $\left({ }^{\circ} \mathbf{C}\right)$} \\
\hline & $100 / 40$ & $150 / 40$ & $200 / 40$ & $300 / 40$ & $100 / 50$ & $150 / 50$ & $200 / 50$ & $300 / 50$ & $100 / 60$ & $150 / 60$ & $200 / 60$ & $300 / 60$ \\
\hline Oksidovani monoterpeni & 31,52 & 32,86 & 33,4 & $\mathbf{3 1 , 5 7}$ & 25,03 & 27,69 & 27,10 & 27,65 & 23,77 & 25,99 & 27,10 & 30,13 \\
\hline 1,8-Cineol & 0,61 & 0,91 & 0,99 & 2,00 & 0,48 & 0,71 & 1,15 & 0,89 & 0,20 & 0,71 & 1,00 & 1,09 \\
\hline Linalool & 27,80 & 29,33 & 29,40 & 26,09 & 21,33 & 24,35 & 23,12 & 23,55 & 21,64 & 22,83 & 23,90 & 26,26 \\
\hline Kamfor & 0,39 & 0,28 & 0,34 & 0,38 & - & 0,20 & 0,31 & 0,29 & - & - & - & - \\
\hline$\alpha$-Terpineol & 1,03 & 0,92 & 1,05 & 1,50 & 2,00 & 0,98 & 1,21 & 1,42 & 1,04 & 1,11 & 1,10 & 0,66 \\
\hline Geraniol & 1,25 & 0,95 & 1,19 & 0,96 & 1,22 & 1,06 & 0,74 & 1,10 & 0,89 & 1,34 & 1,10 & 1,61 \\
\hline Bornilacetat & 0,44 & 0,47 & 0,43 & 0,64 & - & 0,39 & 0,57 & 0,40 & - & - & - & 0,51 \\
\hline $\begin{array}{c}\text { Aromatični oksidovani } \\
\text { monoterpeni }\end{array}$ & 17,14 & 15,8 & 16,68 & 17,23 & 19,62 & 16,76 & 19,07 & 14,91 & 20,29 & 19,93 & 18,90 & 15,75 \\
\hline Eugenol & 15,56 & 14,36 & 14,86 & 16,09 & 17,69 & 15,37 & 17,87 & 13,72 & 19,41 & 18,90 & 18,0 & 14,03 \\
\hline Metil-havikol & 1,58 & 1,44 & 1,82 & 1,14 & 1,93 & 1,39 & 1,20 & 1,19 & 0,88 & 1,03 & 0,90 & 1,72 \\
\hline $\begin{array}{c}\text { Seskviterpenski } \\
\text { ugljovodonici }\end{array}$ & 33,1 & 34,37 & 32,24 & 34,81 & 38,81 & 35,56 & 34,26 & 27,68 & 35,71 & 32,15 & 35,60 & 33,98 \\
\hline$\beta$-Kubeben & 0,58 & 0,94 & 0,74 & 0,86 & 0,98 & 0,73 & 0,88 & 0,96 & 0,75 & 0,61 & 0,90 & 0,60 \\
\hline$\beta$-Elemen & 0,99 & 1,03 & 0,85 & 1,16 & 1,38 & 0,82 & 1,32 & 0,66 & 1,06 & 0,99 & 1,00 & 1,58 \\
\hline Trans-Kariofilen & 0,74 & 0,75 & 0,39 & 0,61 & 0,81 & 0,69 & - & 0,52 & 0,82 & 0,58 & 0,70 & 0,56 \\
\hline$\alpha$-Bergamoten & 4,26 & 5,56 & 5,23 & 5,57 & 5,24 & 5,23 & 4,12 & 4,14 & 4,19 & 5,19 & 5,00 & 4,67 \\
\hline$\alpha$-Humulen & 1,11 & 1,29 & 1,11 & 1,20 & 1,25 & 1,05 & 1,31 & 1,07 & 1,40 & 0,96 & 1,00 & 0,73 \\
\hline Germakren D & 5,30 & 4,81 & 5,00 & 5,63 & 5,29 & 4,42 & 4,52 & 4,30 & 4,89 & 2,54 & 4,70 & 5,47 \\
\hline$\gamma$-Kadinen & 4,55 & 4,54 & 4,13 & 4,31 & 4,83 & 4,83 & 4,58 & 3,36 & 5,49 & 4,87 & 4,30 & 4,26 \\
\hline$\delta$-Kadinen & 11,64 & 11,37 & 10,72 & 10,67 & 13,05 & 12,69 & 12,29 & 9,16 & 14,03 & 13,28 & 12,40 & 12,02 \\
\hline$\alpha$-Selinen & 0,99 & 1,45 & 1,32 & 1,29 & 1,88 & 1,84 & 1,36 & 0,70 & - & 1,39 & 1,60 & 1,13 \\
\hline$\beta$-Selinen & 2,94 & 2,63 & 2,75 & 3,51 & 3,35 & 2,74 & 3,21 & 2,14 & 3,08 & 1,74 & 3,00 & 2,96 \\
\hline$\gamma$-Elemen & - & - & - & - & 0,75 & 0,52 & 0,67 & 0,67 & - & - & 1,00 & - \\
\hline Oksidovani seskviterpeni & 2,12 & 2,13 & 2,21 & 2,01 & 2,26 & 2,67 & 1,92 & 1,67 & 2,59 & 2,70 & 2,30 & 1,63 \\
\hline Spatulenol & 2,12 & 2,13 & 2,21 & 2,01 & 2,26 & 2,67 & 1,92 & 1,67 & 2,59 & 2,70 & 2,30 & 1,63 \\
\hline Ukupno & 83,88 & 85,16 & 84,53 & 85,62 & 85,72 & 83,29 & 82,35 & 71,91 & 82,36 & 80,77 & 83,9 & 81,49 \\
\hline
\end{tabular}


Tabela 16. Kvantitativna analiza totalnih ekstrakata bosiljka

\begin{tabular}{|c|c|c|c|c|c|c|c|c|c|c|c|c|}
\hline \multirow{3}{*}{ Komponente } & \multicolumn{12}{|c|}{ Sadržaj komponente $(\%, \mathrm{~g} / 100 \mathrm{~g}$ ekstrakta) } \\
\hline & \multicolumn{12}{|c|}{ Pritisak (bar)/temperatura $\left({ }^{\circ} \mathbf{C}\right)$} \\
\hline & $100 / 40$ & $150 / 40$ & $200 / 40$ & $300 / 40$ & $100 / 50$ & $150 / 50$ & $200 / 50$ & $300 / 50$ & $100 / 60$ & $150 / 60$ & $200 / 60$ & $300 / 60$ \\
\hline Oksidovani monoterpeni & 18,73 & 14,98 & 17,12 & 13,48 & 13,48 & 13,62 & 11,75 & 11,98 & 11,42 & 12,11 & 11,10 & 8,40 \\
\hline 1,8-Cineol & 0,23 & 0,35 & 0,44 & 1,10 & 0,25 & 0,29 & 0,68 & 0,45 & 0,10 & 0,33 & 0,47 & 0,28 \\
\hline Linalool & 16,60 & 13,23 & 15,11 & 10,72 & 11,79 & 11,87 & 9,58 & 10,14 & 10,00 & 10,63 & 9,66 & 6,99 \\
\hline Kamfor & 0,23 & 0,13 & 0,17 & 0,16 & - & 0,10 & 0,13 & 0,12 & - & - & - & - \\
\hline$\alpha$-Terpineol & 0,60 & 0,47 & 0,51 & 0,80 & 0,79 & 0,53 & 0,69 & 0,54 & 0,69 & 0,62 & 0,53 & 0,28 \\
\hline Geraniol & 0,81 & 0,59 & 0,67 & 0,44 & 0,65 & 0,64 & 0,43 & 0,56 & 0,63 & 0,53 & 0,44 & 0,71 \\
\hline Bornilacetat & 0,26 & 0,21 & 0,22 & 0,26 & - & 0,19 & 0,24 & 0,17 & - & - & - & 0,14 \\
\hline $\begin{array}{c}\text { Aromatični oksidovani } \\
\text { monoterpeni }\end{array}$ & 10,16 & 7,21 & 8,5 & 7,27 & 10,40 & 8,62 & 7,92 & 6,51 & $\mathbf{9 , 4 3}$ & $\mathbf{9 , 4 2}$ & 7,82 & 4,16 \\
\hline Eugenol & 9,29 & 6,48 & 7,64 & 6,61 & 9,78 & 7,97 & 7,40 & 5,91 & 8,97 & 8,80 & 7,28 & 3,74 \\
\hline Metil-havikol & 0,87 & 0,73 & 0,86 & 0,66 & 0,62 & 0,65 & 0,52 & 0,60 & 0,46 & 0,62 & 0,54 & 0,42 \\
\hline Seskviterpenski ugljovodonici & 19,76 & 15,58 & 16,57 & 14,29 & 21,44 & 17,34 & 14,19 & 11,9 & 16,51 & 14,97 & 14,37 & 9,04 \\
\hline$\beta$-Kubeben & 0,35 & 0,42 & 0,38 & 0,35 & 0,54 & 0,36 & 0,36 & 0,41 & 0,35 & 0,28 & 0,36 & 0,16 \\
\hline$\beta$-Elemen & 0,59 & 0,46 & 0,44 & 0,48 & 0,76 & 0,40 & 0,55 & 0,28 & 0,49 & 0,46 & 0,40 & 0,42 \\
\hline Trans-Kariofilen & 0,44 & 0,34 & 0,20 & 0,25 & 0,45 & 0,34 & - & 0,22 & 0,38 & 0,27 & 0,28 & 0,15 \\
\hline$\alpha$-Bergamoten & 2,54 & 2,59 & 2,69 & 2,29 & 2,90 & 2,55 & 1,71 & 1,78 & 1,94 & 2,42 & 2,02 & 1,24 \\
\hline$\alpha$-Humulen & 0,66 & 0,58 & 0,57 & 0,49 & 0,69 & 0,51 & 0,54 & 0,46 & 0,65 & 0,45 & 0,40 & 0,19 \\
\hline Germakren D & 3,16 & 2,17 & 2,57 & 2,31 & 2,92 & 2,15 & 1,87 & 1,85 & 2,26 & 1,18 & 1,90 & 1,46 \\
\hline$\gamma$-Kadinen & 2,72 & 2,05 & 2,12 & 1,77 & 2,67 & 2,35 & 1,90 & 1,45 & 2,54 & 2,27 & 1,74 & 1,13 \\
\hline$\delta$-Kadinen & 6,95 & 5,13 & 5,51 & 4,38 & 7,21 & 6,19 & 5,09 & 3,94 & 6,48 & 6,18 & 5,01 & 3,20 \\
\hline$\alpha$-Selinen & 0,59 & 0,65 & 0,68 & 0,53 & 1,04 & 0,90 & 0,56 & 0,30 & - & 0,65 & 0,65 & 0,30 \\
\hline$\beta$-Selinen & 1,76 & 1,19 & 1,41 & 1,44 & 1,85 & 1,34 & 1,33 & 0,92 & 1,42 & 0,81 & 1,21 & 0,79 \\
\hline$\gamma$-Elemen & - & - & - & - & 0,41 & 0,25 & 0,28 & 0,29 & - & - & 0,40 & - \\
\hline Oksidovani seskviterpeni & 1,27 & 0,96 & 1,14 & $\mathbf{0 , 8 3}$ & 1,25 & 1,30 & $\mathbf{0 , 8 0}$ & $\mathbf{0 , 7 2}$ & 1,20 & 1,26 & $\mathbf{0 , 9 3}$ & $\mathbf{0 , 4 3}$ \\
\hline Spatulenol & 1,27 & 0,96 & 1,14 & 0,83 & 1,25 & 1,30 & 0,80 & 0,72 & 1,20 & 1,26 & 0,93 & 0,43 \\
\hline Ukupno & 49,92 & 38,73 & 43,33 & 35,87 & 46,57 & 35,7 & 34,66 & 31,11 & 38,56 & 37,76 & 34,22 & 22,03 \\
\hline Neidentifikovane komponente & 50,08 & 61,27 & 56,67 & 64,13 & 53,43 & 64,3 & 65,34 & 68,89 & 61,44 & 62,24 & 65,78 & 77,97 \\
\hline
\end{tabular}


Tabela 17. Prinos ekstrakcije komponenata bosiljka (mg/100 g droge)

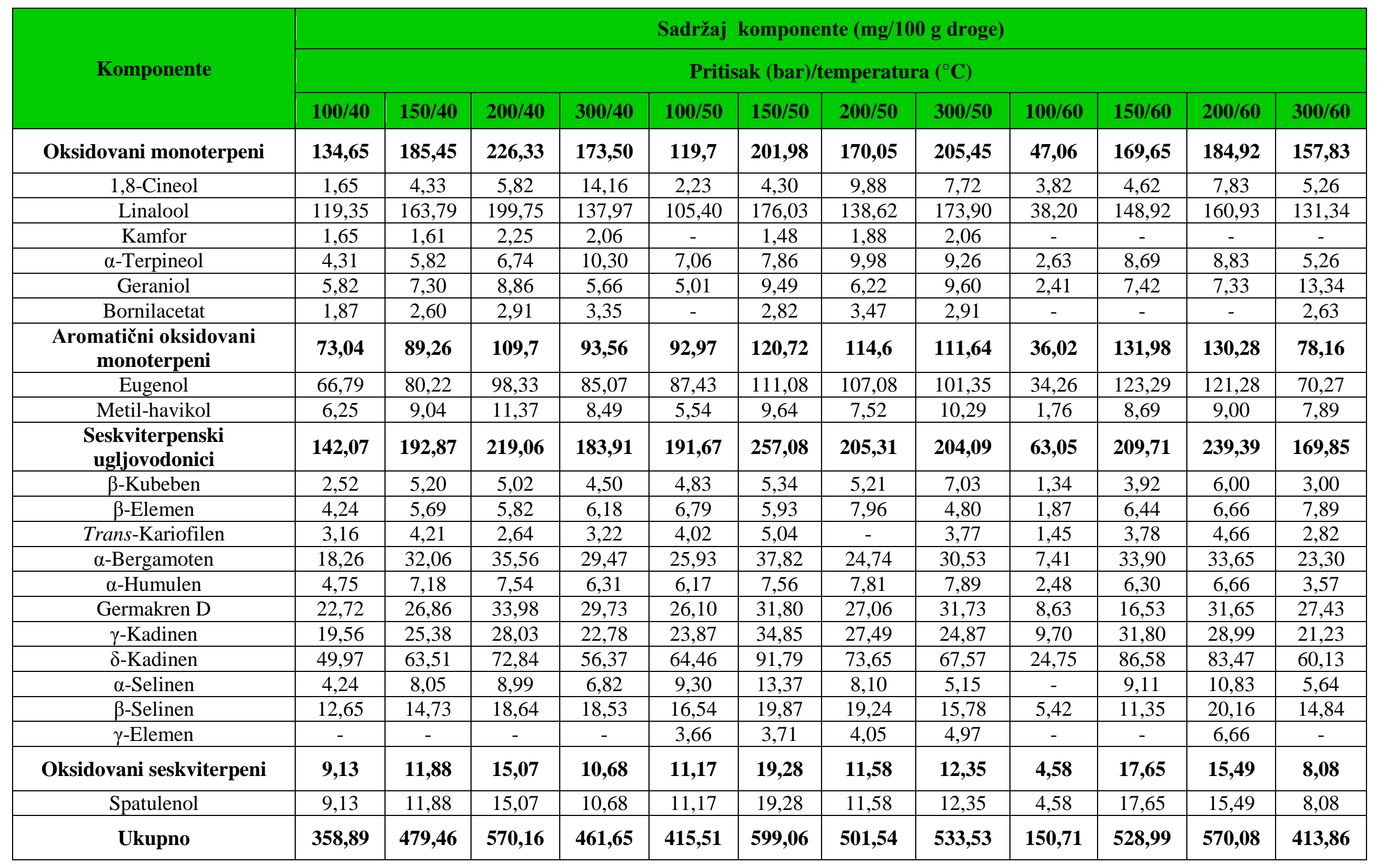


Tabela 18. Relativni udeo komponenata ekstrakata dobijenih frakcionisanjem lipofilnih komponenata

\begin{tabular}{|c|c|c|c|c|c|c|c|c|c|c|c|c|}
\hline \multirow{3}{*}{ Komponente } & \multicolumn{12}{|c|}{ Relativni udeo (\%) } \\
\hline & \multicolumn{12}{|c|}{ Pritisak (bar)/temperatura $\left({ }^{\circ} \mathbf{C}\right)$} \\
\hline & $100 / 40$ & $150 / 40$ & $200 / 40$ & $300 / 40$ & $100 / 50$ & 150/50 & $200 / 50$ & 300/50 & $100 / 60$ & $150 / 60$ & $200 / 60$ & $300 / 60$ \\
\hline Oksidovani monoterpeni & 36,42 & 16,88 & 8,93 & 8,71 & 30,12 & 17,58 & 10,14 & 7,25 & 25,26 & 17,18 & 7,19 & 3,38 \\
\hline 1,8-Cineol & 0,55 & 0,82 & - & - & 0,38 & - & - & - & 0,22 & - & - & - \\
\hline Linalool & 32,68 & 13,93 & 7,93 & 8,26 & 26,84 & 15,91 & 9,00 & 5,29 & 22,43 & 14,81 & 5,25 & 2,64 \\
\hline Kamfor & 0,36 & - & - & - & 0,23 & - & - & - & 0,28 & - & - & - \\
\hline$\alpha$-Terpineol & 1,05 & 1,00 & 0,42 & - & 0,99 & 0,70 & 0,30 & 0,71 & 0,84 & 0,85 & 0,41 & - \\
\hline Geraniol & 1,39 & 1,13 & 0,58 & 0,45 & 1,22 & 0,97 & 0,84 & 1,25 & 1,13 & 1,04 & 1,53 & 0,74 \\
\hline Bornilacetat & 0,39 & - & - & - & 0,46 & - & - & - & 0,36 & 0,48 & - & - \\
\hline Aromatični oksidovani monoterpeni & 16,24 & 17,14 & 11,26 & $\mathbf{9 , 8 1}$ & 16,59 & 18,42 & 17,09 & 18,28 & 19,05 & 16,68 & 17,80 & 3,10 \\
\hline $\begin{array}{r}\text { Eugenol } \\
\end{array}$ & 14,15 & 16,77 & 11,26 & 9,81 & 15,07 & 17,75 & 17,09 & 18,28 & 17,89 & 16,11 & 17,80 & 3,10 \\
\hline Metil-havikol & 2,09 & 0,37 & - & - & 1,52 & 0,67 & - & - & 1,16 & 0,57 & - & - \\
\hline Seskviterpenski ugljovodonici & 33,57 & 38,26 & 13,31 & 21,25 & 33,56 & 36,97 & 43,55 & 43,21 & 36,59 & 39,16 & 41,68 & 4,29 \\
\hline$\beta$-Kubeben & 0,96 & 0,84 & 0,53 & - & 0,68 & 0,88 & 1,79 & 1,06 & 1,04 & 0,89 & 1,12 & - \\
\hline$\beta$-Elemen & 1,03 & 1,47 & - & - & 1,02 & 1,05 & 2,14 & 0,98 & 1,05 & 0,83 & 1,57 & - \\
\hline Trans-Kariofilen & 0,76 & 1,05 & - & - & 0,62 & 0,89 & - & - & 0,66 & 0,81 & - & - \\
\hline$\delta$-Kadinen & 9,90 & 14,22 & - & 12,00 & 11,54 & 15,43 & 16,49 & 18,43 & 12,54 & 15,99 & 16,75 & 2,21 \\
\hline$\alpha$-Selinen & 1,06 & 1,06 & 0,74 & - & 0,98 & 0,78 & 1,39 & 2,77 & 1,05 & 1,19 & 2,29 & - \\
\hline$\beta$-Selinen & 2,79 & 2,25 & 3,57 & 1,25 & 2,81 & 2,42 & 2,99 & 2,99 & 3,18 & 2,84 & 3,08 & 0,22 \\
\hline$\gamma$-Elemen & 0,77 & - & 1,38 & - & 0,40 & - & - & - & 0,60 & - & - & - \\
\hline Oksidovani seskviterpeni & 1,52 & 3,09 & 1,67 & 1,92 & 1,93 & 2,96 & 3,06 & $\mathbf{3 , 3 1}$ & 2,11 & 2,76 & 2,8 & 0,62 \\
\hline Spatulenol & 1,52 & 3,09 & 1,67 & 1,92 & 1,93 & 2,96 & 3,06 & 3,31 & 2,11 & 2,76 & 2,8 & 0,62 \\
\hline Ukupno & 88,11 & $\mathbf{7 5 , 3 7}$ & 35,17 & 41,69 & 82,2 & 75,93 & 73,84 & 72,05 & 83,01 & 75,78 & 69,47 & 11,39 \\
\hline Neidentifikovane komponente & 11,89 & 24,63 & 64,83 & 50,31 & 17,8 & 24,07 & 26,16 & 27,95 & 16,99 & 24,22 & 30,53 & 80,61 \\
\hline
\end{tabular}


Tabela 19. Rezultati kvantitativne analize ekstrakata bosiljka dobijenih frakcionisanjem

\begin{tabular}{|c|c|c|c|c|c|c|c|c|c|c|c|c|}
\hline \multirow{3}{*}{ Komponente } & \multicolumn{12}{|c|}{ Sadržaj komponente (\%, g/100 g ekstrakta) } \\
\hline & \multicolumn{12}{|c|}{ Pritisak (bar)/temperatura $\left({ }^{\circ} \mathbf{C}\right)$} \\
\hline & $100 / 40$ & $150 / 40$ & $200 / 40$ & $300 / 40$ & 100/50 & $150 / 50$ & $200 / 50$ & $300 / 50$ & $100 / 60$ & $150 / 60$ & $200 / 60$ & $300 / 60$ \\
\hline Oksidovani monoterpeni & 22,94 & 4,69 & 1,61 & 0,91 & 18,77 & 5,41 & $\mathbf{3 , 3 7}$ & 1,62 & 16,03 & $\mathbf{6 , 0 2}$ & 2,56 & 1,56 \\
\hline 1,8-Cineol & 0,30 & 0,47 & - & - & 0,28 & - & - & - & 0,1 & - & - & - \\
\hline Linalool & 20,71 & 3,36 & 1,2 & 0,74 & 16,57 & 4,74 & 2,89 & 1,04 & 14,15 & 5,14 & 2,04 & 1,22 \\
\hline Kamfor & 0,23 & - & - & - & 0,14 & - & - & - & 0,18 & - & - & - \\
\hline$\alpha$-Terpineol & 0,64 & 0,56 & 0,16 & - & 0,67 & 0,33 & 0,14 & 0,23 & 0,59 & 0,34 & 0,15 & - \\
\hline Geraniol & 0,81 & 0,30 & 0,25 & 0,17 & 0,83 & 0,34 & 0,34 & 0,35 & 0,78 & 0,37 & 0,37 & 0,34 \\
\hline Bornilacetat & 0,25 & - & - & - & 0,28 & - & - & - & 0,23 & 0,17 & - & - \\
\hline Aromatični oksidovani monoterpeni & 10,09 & 4,22 & 1,7 & $\mathbf{0 , 8 7}$ & 10,16 & 5,49 & 5,49 & 3,59 & 12,02 & 5,79 & 6,92 & 1,43 \\
\hline Eugenol & 8,97 & 4,05 & 1,70 & 0,87 & 9,30 & 5,29 & 5,49 & 3,59 & 11,29 & 5,59 & 6,92 & 1,43 \\
\hline Metil-havikol & 1,12 & 0,17 & - & - & 0,86 & 0,20 & - & - & 0,73 & 0,20 & - & - \\
\hline Seskviterpenski ugljovodonici & 21,27 & 9,22 & 2,01 & 1,91 & 20,71 & 11,01 & 13,96 & 8,49 & 23,08 & 13,59 & 16,21 & $\mathbf{1 , 9 8}$ \\
\hline$\beta$-Kubeben & 0,61 & 0,20 & 0,08 & - & 0,42 & 0,26 & 0,57 & 0,21 & 0,66 & 0,31 & 0,44 & - \\
\hline$\beta$-Elemen & 0,65 & 0,35 & - & - & 0,63 & 0,31 & 0,67 & 0,19 & 0,66 & 0,29 & 0,61 & - \\
\hline Trans-Kariofilen & 0,48 & 0,25 & - & - & 0,38 & 0,27 & - & - & 0,42 & 0,28 & - & - \\
\hline$\alpha$-Bergamoten & 3,28 & 1,49 & 0,59 & 0,27 & 3,21 & 1,65 & 1,84 & 0,99 & 3,50 & 1,70 & 2,01 & 0,40 \\
\hline$\alpha$-Humulen & 0,87 & 0,26 & 0,05 & - & 0,56 & 0,30 & 0,50 & 0,18 & 0,52 & 0,47 & 0,47 & - \\
\hline Germakren D & 3,59 & 1,07 & 0,40 & 0,18 & 3,07 & 1,32 & 1,73 & 0,93 & 3,38 & 1,57 & 1,85 & 0,28 \\
\hline$\gamma$-Kadinen & 2,59 & 1,37 & 0,03 & 0,27 & 2,73 & 1,35 & 1,94 & 1,24 & 2,99 & 2,02 & 2,23 & 0,18 \\
\hline$\delta$-Kadinen & 6,27 & 3,43 & - & 1,08 & 7,12 & 4,60 & 5,30 & 3,62 & 7,91 & 5,55 & 6,51 & 1,02 \\
\hline$\alpha$-Selinen & 0,67 & 0,26 & 0,11 & - & 0,61 & 0,23 & 0,45 & 0,54 & 0,66 & 0,41 & 0,89 & - \\
\hline$\beta$-Selinen & 1,77 & 0,54 & 0,54 & 0,11 & 1,73 & 0,72 & 0,96 & 0,59 & 2,00 & 0,99 & 1,20 & 0,10 \\
\hline$\gamma$-Elemen & 0,49 & - & 0,21 & - & 0.25 & - & - & - & 0,38 & - & - & - \\
\hline Oksidovani seskviterpeni & 0,96 & 0,74 & 0,25 & $\mathbf{0 , 1 7}$ & 1,19 & $\mathbf{0 , 8 8}$ & $\mathbf{0 , 9 8}$ & 0,65 & 1,33 & 0,96 & 1,09 & 0,29 \\
\hline Spatulenol & 0,96 & 0,74 & 0,25 & 0,17 & 1,19 & 0,88 & 0,98 & 0,65 & 1,33 & 0,96 & 1,09 & 0,29 \\
\hline Ukupno & 55,26 & 18,87 & $\mathbf{5 , 5 7}$ & 3,86 & 50,83 & 22,79 & 23,8 & 14,35 & 52,46 & 26,36 & 26,78 & 5,26 \\
\hline Neidentifikovane komponente & 44,74 & 81,13 & 94,43 & 96,14 & 49,17 & 77,21 & 76,2 & 85,65 & 47,54 & 73,64 & 73,22 & 94,74 \\
\hline
\end{tabular}


Tabela 20. Prinos ekstrakcije komponenata bosiljka dobijenih frakcionisanjem (mg/100 g droge)

\begin{tabular}{|c|c|c|c|c|c|c|c|c|c|c|c|c|}
\hline \multirow{3}{*}{ Komponente } & \multicolumn{12}{|c|}{ Sadržaj komponente $(\mathrm{mg} / 100 \mathrm{~g}$ droge $)$} \\
\hline & \multicolumn{12}{|c|}{ Pritisak (bar)/temperatura $\left({ }^{\circ} \mathbf{C}\right)$} \\
\hline & $100 / 40$ & $150 / 40$ & $200 / 40$ & $300 / 40$ & $100 / 50$ & $150 / 50$ & 200/50 & $300 / 50$ & $100 / 60$ & $150 / 60$ & $200 / 60$ & $300 / 60$ \\
\hline Oksidovani monoterpeni & 158,97 & 20,54 & 4,36 & 1,25 & 189,2 & 37,5 & 11,73 & 5,71 & 105,31 & 50,62 & 12,13 & 3,64 \\
\hline 1,8-Cineol & 2,08 & 2,06 & - & - & 2,82 & - & - & - & 0,66 & - & - & - \\
\hline Linalool & 143,52 & 14,72 & 3,25 & 1,02 & 167,03 & 32,85 & 10,06 & 3,67 & 92,96 & 43,22 & 9,67 & 2,85 \\
\hline Kamfor & 1,59 & - & - & - & 1,41 & - & - & - & 1,18 & - & - & - \\
\hline$\alpha$-Terpineol & 4,44 & 2,45 & 0,43 & - & 6,75 & 2,29 & 0,49 & 0,81 & 3,88 & 2,86 & 0,71 & - \\
\hline Geraniol & 5,61 & 1,31 & 0,68 & 0,23 & 8,37 & 2,36 & 1,18 & 1,23 & 5,12 & 3,11 & 1,75 & 0,79 \\
\hline Bornilacetat & 1,73 & - & - & - & 2,82 & - & - & - & 1,51 & 1,43 & - & - \\
\hline Aromatični oksidovani monoterpeni & 69,92 & 18,48 & 4,61 & 1,20 & 102,41 & 38,05 & 19,10 & 12,67 & $\mathbf{7 8 , 9 7}$ & 48,69 & 32,8 & 3,35 \\
\hline Eugenol & 62,16 & 17,74 & 4,61 & 1,20 & 93,74 & 36,66 & 19,10 & 12,67 & 74,17 & 47,01 & 32,80 & 3,35 \\
\hline Metil-havikol & 7,76 & 0,74 & - & - & 8,67 & 1,39 & - & - & 4,80 & 1,68 & - & - \\
\hline Seskviterpenski ugljovodonici & 147,4 & 40,39 & 5,45 & 2,63 & 208,75 & 76,29 & 48,57 & 29,96 & 151,65 & 114,28 & 76,85 & 4,63 \\
\hline$\beta$-Kubeben & 4,23 & 0,88 & 0,22 & - & 4,23 & 1,80 & 1,98 & 0,74 & 4,34 & 2,61 & 2,09 & - \\
\hline$\beta$-Elemen & 4,50 & 1,53 & - & - & 6,35 & 2,15 & 2,33 & 0,67 & 4,34 & 2,44 & 2,89 & - \\
\hline Trans-Kariofilen & 3,33 & 1,10 & - & - & 3,83 & 1,87 & - & - & 2,76 & 2,35 & - & - \\
\hline$\alpha$-Bergamoten & 22,73 & 6,53 & 1,60 & 0,37 & 32,36 & 11,43 & 6,40 & 3,49 & 22,99 & 14,30 & 9,53 & 0,94 \\
\hline$\alpha$-Humulen & 6,03 & 1,14 & 0,14 & - & 5,64 & 2,08 & 1,74 & 0,63 & 3,42 & 3,95 & 2,23 & - \\
\hline Germakren D & 24,88 & 4,69 & 1,08 & 0,25 & 30,94 & 9,15 & 6,02 & 3,28 & 22,21 & 13,20 & 8,77 & 0,65 \\
\hline$\gamma$-Kadinen & 17,95 & 6,00 & 0,08 & 0,37 & 27,52 & 9,35 & 6,75 & 4,38 & 19,64 & 16,99 & 10,57 & 0,42 \\
\hline$\delta$-Kadinen & 43,45 & 15,02 & - & 1,49 & 71,77 & 31,88 & 18,44 & 12,78 & 51,97 & 46,67 & 30,86 & 2,39 \\
\hline$\alpha$-Selinen & 4,64 & 1,14 & 0,30 & - & 6,15 & 1,59 & 1,57 & 1,91 & 4,34 & 3,45 & 4,22 & - \\
\hline$\beta$-Selinen & 12,26 & 2,36 & 1,46 & 0,15 & 17,44 & 4,99 & 3,34 & 2,08 & 13,14 & 8,32 & 5,69 & 0,23 \\
\hline$\gamma$-Elemen & 3,40 & - & 0,57 & - & 2,52 & - & - & - & 2,50 & - & - & - \\
\hline Oksidovani seskviterpeni & 6,39 & 3,24 & 0,68 & $\mathbf{0 , 2 3}$ & 11,99 & 6,10 & 3,41 & 2,29 & 8,74 & 8,07 & 5,17 & $\mathbf{0 , 6 8}$ \\
\hline Spatulenol & 6,39 & 3,24 & 0,68 & 0,23 & 11,99 & 6,10 & 3,41 & 2,29 & 8,74 & 8,07 & 5,17 & 0,68 \\
\hline Ukupno & 382,68 & 82,65 & 15,10 & 5,31 & 512,35 & 157,94 & 82,81 & 50,63 & 344,67 & 221,66 & 126,95 & 12,3 \\
\hline
\end{tabular}

